UNIVERSIDAD NACIONAL DE LA PLATA

FACULTAD DE HUMANIDADES Y CIENCIAS DE LA EDUCACIÓN SeCRETARÍA DE POSGRADO

\title{
LAS MEMORIAS QUE SEREMOS
}

Memoria y olvido en el discurso oficial sobre el conflicto armado colombiano en el pasado reciente

Marda Ucaris Zuluaga Aristizábal

Tesis para optar por el grado de Magíster en Historia y Memoria

Directora,

Valentina Salvi, Conicet-UBA

Codirectores,

Elsa Blair T., Universidad de Antioquia

Santiago Cueto Rúa, UNLP

La Plata, 7 de mayo de 2014 


\section{AGRADECIMIENTOS}

Al Ministerio de Educación de la República Argentina y su programa de Becas Roberto Carri, sin el cual tal vez no me habría animado a hacer esta Maestría, tan alejada aparentemente de mi formación profesional pero tan cercana a mi realidad de colombiana.

A Andrés Bisso y Ana Barletta, coordinadores de la Maestría en Historia y Memoria, quienes siempre tuvieron la mejor disposición y toda la voluntad para acompañarnos a los extranjeros en nuestro proceso de formación.

A todos los compañeros que, de distintas maneras, apoyaron la elaboración de esta tesis y no dejaron que sucumbiera ante la dificultad y el reto intelectual que supuso.

A Elsa, por haber sido una guía incondicional y animarme siempre a descubrir lo que quería estudiar y decir, y a no ceder en ese deseo.

A Valentina, por su lectura juiciosa, su insistencia en el tratamiento de temas fundamentales y el rigor que le impuso a la escritura.

A Santiago, que en cada encuentro para conversar sobre la tesis me iluminaba con sus preguntas y sugerencias un pedazo del camino en el que no había pensado antes.

Al Centro de Memoria Histórica de Colombia, cuya existencia descubrí recién llegada a la Argentina y cuya labor inspiró las preguntas que dieron origen y forma a lo que aquí presento.

A los amigos entrañables que me escucharon una y mil veces hablando del espinoso tema del conflicto armado y se dejaron tocar por esa realidad tan cruda en la que nos acostumbramos a vivir pero que muchas veces ya no vemos. 



\section{TABLA DE CONTENIDO}

¿Y cómo es posible no saber tanto? Notas preliminares

Introducción y apuntes metodológicos

Capítulo 1: EL PAÍS DE TODAS LAS LUCHAS. Tipos de confrontación y actores armados en Colombia

1.1 Lo que no se quiere, se mata. Democracia y exclusión en la política colombiana. 1.2 Principales actores del conflicto armado colombiano.

1.2.1 Los grupos guerrilleros

1.2.2 La fuerza pública del Estado

1.2.3 El fenómeno paramilitar

$1.3 \mathrm{Y}$ ahora, ¿quién podrá defendernos? Guerra, violencia y conflicto armado en Colombia

1.4 Indultos y amnistías: guerra y olvido en Colombia

Anexo 1. Un ejemplo de institucionalización del olvido: el pacto de silencio de 1962.

Capítulo 2: Del silencio a la evocación. Políticas de memoria y olvido sobre el conflicto armado colombiano

2.1 Entender y recordar: de las Comisiones de estudios sobre la violencia al Centro de Memoria Histórica

2.1.1 La comisión naciones investigadora (1958)

2.1.2 Comisión de estudios sobre la violencia (1987)

2.1.3 Comisión superadora de la violencia

2.2 Un Estado, dos formas de asumir el deber de memoria

2.3 Entre la paradoja y el desafío: conformación y acciones del Grupo de Memoria Histórica

2.3.1 Trabajo con-sentido. Fases y metodologías de $\mathrm{GMH}$

2.3.2 La voz de las víctimas

2.4 De Grupo a Centro de Memoria Histórica

2.5 El jardín de las versiones que se bifurcan

Capítulo 3: Las memorias que seremos. Análisis del informe general sobre el conflicto armado del GMH

3.1 Una narración vertiginosa: panorama de la producción del GMH

3.2 La memoria como resistencia y como acto político: posición fundamental del GMH 
3.3 iBasta ya! Un grito en medio del conflicto: estrategias discursivas y estructura del informe

3.3.1 El manejo de la palabra: un rasgo distintivo del GMH

3.3.2 De la comprensión a la esperanza: estructura del informe ¡Basta ya!

3.3.3 Retórica de las imágenes: un discurso paralelo y silencioso

3.4 Toda apuesta tiene su costo: alcances y límites de las propuestas de sentido del GMH

\section{Conclusiones}

\section{Bibliografía}




\section{Notas preliminares \\ ¿Y CÓMO ES POSIBLE NO SABER TANTO?}

“¿Y cómo es posible no saber tanto?” Alejandra Pizarnik

Como siempre, hay que tomar palabras prestadas para poder decir alguna cosa. No sé a qué se refería Pizarnik cuando escribió esas líneas, pero a mí me resultan de una precisión pasmosa para "explicar" por qué yo, que estudié psicología, terminé haciendo una Maestría en Historia y Memoria y eligiendo como tema de tesis el discurso oficial sobre el conflicto armado colombiano. Desde que decidí viajar a Argentina e inscribirme en este posgrado tenía la idea de estudiar algo relacionado con la violencia, aunque partiendo de una perspectiva distinta: las creencias que la legitiman, específicamente en Medellín. Esa pregunta había surgido en el último de mis trabajos en la Facultad Nacional de Salud Pública, a raíz de una investigación que habían hecho allí y que mencionaba ese factor como uno de los determinantes en la situación de violencia que se volvió hace mucho permanente en la ciudad. Sin embargo, una vez en Argentina, comenzaron a surgir otras preguntas y en una clase en la que se dio una discusión sobre la posición del Estado colombiano frente al conflicto, empecé a tomar conciencia de que había muchas cosas que no sabía sobre él. Comenzó a parecerme inverosímil y vergonzoso que una persona como yo, descendiente de una familia de Granada (Antioquia) -donde han pasado cosas muy graves en relación con el conflicto armado-, y que creció en Medellín la conmocionada década de los ochenta, supiera tan poco acerca del surgimiento y expansión del conflicto, de la historia del país, de las responsabilidades intrincadas y complejas que han permitido que alcance semejante magnitud y duración.

¿Por qué me enseñaron a los trancazos la historia de Colombia? ¿Por qué sólo albergaba en mi mente nombres vacíos que no me remitían a ninguna comprensión -la patria boba, la guerra de los mil días, el bogotazo, el Frente Nacional-? Comencé a sentir que me lo habían ocultado todo, que el Estado se conformaba con que cada quien, dependiendo de la región donde viviera, fuera testigo o víctima del pedazo de conflicto que allí operaba y que de historia supiera lo que alcanzaba a ver y nada más. Eso, obviamente, no era una certeza sino una intuición, una sensación que me incomodaba y me dolía y de la que nació la pregunta por cuál ha sido el discurso oficial sobre el conflicto, el que nos ha llegado, el que se ha difundido más.

Como buena profesional formada en una Facultad de Ciencias Sociales de universidad pública, desconfiaba de todo lo que viniera del Estado, lo miraba con sospecha, pero también por la misma formación que allí recibí quise emprender una búsqueda en la que los prejuicios no me aturdieran. El punto de alarma que me sonó un día en clase, muy al comienzo de la maestría, tenía que ver con la Ley de Justicia y Paz ${ }^{*}$ y el hecho de que en ella se sustituyeron los principios internacionales de "verdad, justicia y reparación" por los muy cuestionados de "perdón y olvido" para poder continuar (una especie de borrón y cuenta nueva). Busqué el texto de la Ley y lo leí completo y, aunque muchas cosas en él me indignaron y me parecieron nefastas (como la negación del conflicto y la preponderancia que se le daba a los grupos armados ilegales por encima de las víctimas) hubo algo que me sorprendió: la creación de la Comisión Nacional de Reparación y Reconciliación y su área de

\footnotetext{
* Con este nombre se conoce la Ley 975 de 2005, que regulaba las condiciones para la desmovilización de miembros de grupos armados ilegales. En el capítulo 2 de la presente tesis se hace un análisis pormenorizado de la misma.
} 
Memoria Histórica. No tenía idea de que había un grupo de Memoria Histórica en el país, conformado durante el gobierno de Álvaro Uribe Vélez, que llevaba ya varios años de labores y varios informes publicados. Pese a esta sorpresa -casi grata- volvió la misma pregunta: ¿y yo por qué no sabía que ese grupo existía? ¿Cómo era posible que una ciudadana medianamente "ilustrada" como yo, de clase media, educada íntegramente en el sistema público, no tuviera idea de que en el país sí había iniciativas (gubernamentales y no gubernamentales) que trabajaban por la memoria? ¿Todo eso pasaba a mis espaldas? ¿O era que yo se las había dado siempre y sólo tuve ojos para ver cuando me fui muy lejos y el conflicto ya no era mi pan de cada día?

La distancia, indudablemente, tuvo algo que ver. Vivir en un país cuyas convulsiones no pasan por grupos guerrilleros y paramilitares y en una ciudad en la que, aunque hay inseguridad, no es común que se oigan tiroteos por las noches, me hizo percibir de manera distinta esa realidad en medio de la cual habité siempre. Toda la vida me dolieron los muertos, me pregunté por qué a tantos les resultaba aparentemente sencillo armarse y disparar contra otros, por qué algunos aplaudían a los encapuchados en la universidad; pero desde lejos todo comenzó a verse más nítido y terrible, a doler más, a desconsolarme a veces.

Quiero entender y que otros que me lean también entiendan. Quiero escribir una tesis que aunque no cambie el curso de los acontecimientos muestre al menos que no son tan pocas las cosas que se hacen, que recoja en un solo lugar lo que yo encontré disperso y me sorprendió, y me aterró a veces (por lo terrible del sufrimiento que han padecido muchos colombianos en medio del conflicto) pero que en cualquier caso me ha dado un ápice de esperanza. No una esperanza ingenua que raya con el idealismo, pero al menos la confianza en que se están tomando acciones para visibilizar a los invisibles de siempre, para hacerlos más fuertes simbólica y políticamente, para paliar un dolor que si sólo se ignora no va a conducir a nada bueno. Una tesis que muestre que el que quiera, ahora, puede ver, que la ceguera que hemos padecido tantos ha sido en gran parte una elección. Como decía un amigo al que le contaba de estas cosas, a veces sucede que incluso cuando pensamos que nada puede pasar, algo está pasando.

$* * *$

Elegí trabajar inicialmente sobre los informes del Grupo de Memoria Histórica sobre Antioquia y eso ha sido quizá lo más difícil. Me he descubierto con inmensas resistencias para leer, con miedo de verme reflejada sin remedio, de encontrar en el informe de San Carlos alguna referencia a un tío que era mayordomo de una finca y que mataron allí, delante de su esposa y de mis primos (algunos eran niños) y que desde ese momento, hace más de veinte años, tuvieron que irse a vivir a Cali, de donde jamás volvieron. No me es fácil leer el informe de la Comuna 13 y encontrar en los testimonios experiencias muy similares a las que viví durante mi infancia en Manrique, el barrio en el que mis padres se instalaron cuando recién llegaron de Granada y del que nos fuimos cuando yo tenía 13 años porque ellos se dijeron que en semejante entorno de bandas y violencia cotidiana no podían seguir criando a sus tres hijos. Ellos, por fortuna, tenían trabajos que les permitieron llevarnos a un barrio más tranquilo, pero muchas familias no pueden darse el lujo ni siquiera de pensar en irse. No es mi culpa y lo sé, pero me duele. Y me duele sobre todo la impotencia. Como no tengo espíritu activista, hago lo que puedo y para lo que se supone que soy buena: estudio y escribo. Trato de salir al menos de la pregunta inicial - ¿y cómo es posible no saber tanto? -, pero se instala otra que se vuelve todavía más agobiante: ¿para qué sirve saber? No lo sé todavía, pero lo prefiero. 


\section{INTRODUCCIÓN}

El conflicto armado colombiano es un problema que afecta al país desde hace décadas y que puede ser -y de hecho ha sido- analizado desde distintas ópticas, haciendo énfasis en aspectos variables según el campo desde el que se mire y las problemáticas que se pretendan comprender: sociales, económicas, políticas, humanitarias, etc.

Una dificultad particular rodea los estudios sobre este conflicto: no se trata de un proceso concluido (Jaramillo, 2009). A diferencia de lo que ha pasado en otros países del Cono Sur, en los que hubo períodos de dictaduras y terrorismo de Estado claramente delimitados, en Colombia sólo ha existido un período de dictadura (1953-1957)', cuya característica más recordada no es la violencia sino, justamente, la "pacificación" temporal que posibilitó. Tampoco puede hablarse estrictamente -o al menos no exclusivamente- de terrorismo de Estado y, si bien hay una fecha que suele tomarse como emblemática del inicio de la violencia (9 de abril de 1948, día del asesinato de Jorge Eliécer Gaitán) no existe un momento de cierre de la violencia que, desde ese 9 de abril, se reconoce como componente constante en la dinámica del país.

Pese a este carácter inacabado del conflicto armado, en Colombia se han emprendido acciones en pro de la construcción de procesos de memoria, en parte porque el espíritu de la época -el boom de la memoria en el mundo, el culto al pasado (Huyssen, 2001)- así lo demanda, y en parte porque desde distintos grupos y organizaciones se ha revelado la necesidad de comenzar a hacer más visibles las dimensiones del conflicto armado, quizá basados en la vieja sentencia de que un pueblo que no conoce su historia está condenado a repetirla.

Más allá de lo cuestionable que pueda resultar tal afirmación y de que no basta con un conocimiento de la historia para escapar de las trampas de la repetición, lo que interesa aquí es indagar por las disputas que en Colombia se han dado en torno a la memoria: cuáles son los sectores que han promovido estos procesos (los emprendedores de memoria, en términos de $J \operatorname{lin}^{2}$ ), qué tipo de demandas han formulado, así como las respuestas que desde el Estado han surgido y las reacciones que, a su vez, han provocado tales respuestas, para comprender el proceso como una interacción y una lucha permanente de fuerzas y sentidos.

Si se parte del supuesto de que en los procesos de memoria están imbricados pasado, presente y futuro, es posible construir una perspectiva de análisis en la que los procesos de memoria sobre el conflicto armado en Colombia tengan sentido. Así, siguiendo a Koselleck

\footnotetext{
${ }^{1}$ Tras el golpe de estado del 13 de junio de 1953, el General Gustavo Rojas Pinilla asumió el poder en lugar del hasta entonces presidente, Laureano Gómez. El golpe contó con la anuencia de las principales fuerzas políticas (liberalismo y conservatismo) y en su transcurso obtuvo un gran apoyo de la sociedad civil por sus logros en cuanto a la desmovilización temporal de las guerrillas, así como por los avances en infraestructura, tecnología y la aprobación del voto femenino. Sin embargo, sus crecientes tendencias populistas y su propuesta de crear un nuevo partido como alternativa a los dos que tradicionalmente habían estado en el poder, debilitaron su posición y en 1957 fue obligado a retirarse de su cargo, con lo que se dio inicio a las negociaciones del Frente Nacional, acuerdo entre liberales y conservadores para alternarse en el poder por un lapso de 16 años en los que ninguna otra fuerza política tuvo posibilidad de participar en los procesos electorales.

${ }^{2}$ Elizabeth Jelin habla de los emprendedores de memoria, haciendo eco de la expresión de Howard Becker «empresarios morales», para referirse a "generadores de proyectos, de nuevas ideas y expresiones, de creatividad -más que de repeticiones-”. Véase: E. Jelin. Los trabajos de la memoria. Capítulo 3: Las luchas políticas por la memoria. Op. cit.
} 
(1993), puede decirse que el presente está configurado a partir del pasado y que, en el mismo presente, se encuentran inscritas unas expectativas de futuro. Jelin (2003, p. 15) dirá que "las experiencias están también moldeadas por el horizonte de expectativas, que hace referencia a una temporalidad futura", lo que señala un punto de intersección entre pasado y futuro que configura el espacio de producción de las memorias.

Con base en estas ideas, puede argumentarse que el conflicto armado colombiano tiene una historia amplia, suficientes años acumulados de acontecer como para ser el sustento de diversas evocaciones y registros. Esa persistencia en el día a día de la historia colombiana, con sus variaciones, recrudecimientos y momentos de aparente tregua, ha jugado un papel en la configuración del presente de la Nación y plantea preocupaciones y retos hacia el futuro. No en vano la Ley 975 de 2005 -conocida como Ley de Justicia y Paz- establece la creación de un una Comisión Nacional de Reparación y Reconciliación con un Área de Memoria Histórica, y la Ley 1448 de 2011 -o Ley de Víctimas- mantiene dentro de sus disposiciones el derecho a la verdad y a la memoria, reconociendo en el presente unos acontecimientos pasados que han afectado de múltiples maneras a la sociedad civil y cuyo conocimiento, difusión y elaboración son centrales para la construcción de un futuro distinto (idealmente menos violento) para el país. Esto es al menos un presupuesto básico, una expectativa que se tiene.

La inquietud que dio origen a esta tesis tiene que ver con las incidencias que sobre una sociedad tiene el discurso oficial en torno a diferentes asuntos, en este caso el conflicto armado colombiano. Luego de hacer un rastreo bibliográfico exhaustivo fue necesario aceptar que no existe una definición precisa de la noción de discurso oficial, aunque sí un gran número de estudios que dicen ocuparse de él. Lo común a tales indagaciones es que toman como objeto de análisis decretos, leyes, edictos, pronunciamientos formales emanados de las autoridades estatales, y será siguiendo esa tradición que realizaremos nuestro trabajo. El discurso oficial sobre el conflicto armado colombiano ha tenido variaciones importantes, en especial en la transición entre los gobiernos de Álvaro Uribe Vélez (2002-2010) y Juan Manuel Santos (2010-2014), cuyas intervenciones públicas y políticas de Estado promovidas sobre el tema son marcadamente contrastantes. Muestra clara de esto es que, mientras el primero negó la existencia del conflicto armado y evitó tal nominación en leyes, decretos y pronunciamientos propios y de funcionarios de su gobierno, durante el gobierno de Santos se ha retomado esa categoría y es la que se usa explícitamente en la Ley de Víctimas, una de las principales fuentes de este proyecto de investigación ${ }^{3}$.

Consciente de la imposibilidad de abordar el tema amplísimo y general del discurso oficial sobre el conflicto armado como totalidad, y consecuente con el hecho de que la tesis se enmarca en una Maestría de Historia y Memoria, el abordaje propuesto dirige su atención a las formas en que la memoria y el olvido aparecen en el discurso oficial sobre el conflicto, con el fin de rastrear las interpretaciones que se presentan, los sentidos que se promueven, las apuestas éticas de las que parten y el lugar otorgado a víctimas, actores del conflicto y sociedad civil en el conjunto de sus construcciones. Se pondrá especial atención a las

\footnotetext{
${ }^{3}$ Para un análisis de las diferencias entre las posiciones de Uribe y Santos en este aspecto y de las consecuencias del reconocimiento oficial del conflicto armado, véase el artículo ¿Qué significa el reconocimiento del conflicto armado por parte del Gobierno?, publicado por la Revista Semana en mayo de 2011, poco antes de la aprobación de la Ley de Víctimas en el Congreso de la República. Disponible en:

http://www.semana.com/nacion/articulo/que-significa-reconocimiento-del-conflicto-armado-parte-delgobierno/239313-3. Las diferencias entre las posiciones de Uribe y Santos en el tratamiento del conflicto, tanto en términos prácticos como discursivos, serán expuestas con detalle en el segundo capítulo de esta tesis.
} 
variaciones que se han ido dando en el discurso oficial sobre el conflicto armado, teniendo en cuenta sus énfasis y el carácter de las intervenciones en función de las posiciones del gobierno de turno.

Un estudio sobre los procesos de memoria en Colombia es pertinente por cuanto contribuirá a la identificación de las iniciativas, los sentidos y valores promovidos desde el Estado, al mismo tiempo que puede ser un aporte para el análisis de su eficacia, en términos de recepción, interpretaciones y efectos producidos. El trabajo aquí presentado se ocupa del discurso oficial a cargo del Grupo de Memoria Histórica -GMH-, organismo que opera desde el año 2007 por mandato de la Ley de Justicia y Paz, y que, en principio, hacía parte de la Comisión Nacional de Reparación y Reconciliación. En 2012, con la entrada en vigencia de la Ley de Víctimas, se amplían las funciones del Grupo y se le otorga autonomía, constituyéndose como Centro de Memoria Histórica. Nuestro propósito central es hacer un seguimiento de su producción escrita haciendo énfasis en el análisis de su contenido, interpretaciones y sentidos promovidos, mientras que nuestra tesis doctoral estará orientada a indagar por la recepción pública, los efectos políticos y los debates surgidos tras la presentación del informe general sobre el conflicto armado presentado por el GMH en el año 2013.

En cuanto al campo de la Historia y la Memoria, la investigación propuesta aborda una dimensión novedosa y problemática: la de la temporalidad de un pasado que, más que reciente, es un pasado presente, por cuanto se refiere a acontecimientos cuyo origen puede rastrearse muchos años atrás en la historia del país, pero que han tenido una evolución que no permite hablar de una conclusión de los mismos. Igualmente, se constituirá en un aporte para pensar las relaciones entre memoria política y políticas de la memoria, esfera de amplio interés en los estudios sobre memoria ${ }^{4}$.

Valga resaltar aquí que la movilidad del objeto de estudio (el GMH y sus informes), que en el transcurso de elaboración de la tesis pasó de ser una mera subárea dentro de una Comisión estatal a constituirse en una entidad autónoma (el Centro Nacional de Memoria Histórica) con funciones más amplias que la sola reconstrucción de la memoria, fue un reto permanente. Las transformaciones no fueron meramente formales sino que cambiaron también, entre una ley y otra (la de Justicia y Paz, y la de Víctimas), los presupuestos que sustentaban su labor y las posibilidades discursivas y prácticas de sus elaboraciones que, por lo demás, han sido copiosas durante sus años de existencia 5 . Por contingencias propias de la realización del posgrado, la culminación de la tesis se vio un poco retrasada pero, al final, esto fue una circunstancia afortunada, pues alcancé a tener en cuenta el informe general sobre el conflicto armado presentado por dicha comisión en julio del 2013, el cual es la condensación de las elaboraciones previas sobre temas y casos regionales que se hicieron antes, justamente con la intención de dar un fundamento sólido al que sería un producto de carácter nacional.

El trabajo presentado está estructurado en tres capítulos: el primero de ellos, titulado El país de todas las luchas, sirve de contexto general sobre la confrontación armada en Colombia y las múltiples formas que ha ido tomando desde principios del Siglo XX, señalando actores, momentos emblemáticos, diversas posiciones gubernamentales y el

\footnotetext{
${ }^{4}$ Ejemplo de esto son los trabajos de Pollak en relación con las memorias oficiales y las subterráneas (Cf. su libri Memoria, olvido, silencio, o su artículo A gestão do indizível) los de Jelin sobre los usos políticos de la memoria o el de Crenzel (La historia política del Nunca Más) sobre la historia política del informe de la CONADEP en Argentina, por mencionar sólo unos pocos.

${ }^{5}$ el GMH tuvo su inicio formal en febrero del 2007
} 
surgimiento y uso de nociones como violencia, guerra y conflicto armado para describir las situaciones que enfrenta el país. Pretende ser, en principio, una guía para el lector argentino, pero su construcción sirvió también para que yo misma, como investigadora proveniente de una disciplina diversa de la historia o la sociología, tuviera un panorama claro de los lugares en que se inscriben las interpretaciones actuales sobre el conflicto armado.

El segundo capítulo, Del silencio a la evocación, está concentrado fundamentalmente en el Grupo de Memoria Histórica en cuanto tal, teniendo en cuenta su inscripción en las políticas colombianas sobre el deber de memoria del Estado en dos momentos distintos: 2005 y 2011, años en que se promulgaron leyes que lo definieron de manera diversa y permitieron la creación y continuidad del Grupo. Hay allí un recuento que va de las leyes a las posibilidades discursivas que condicionaban, pasando por las características del GMH (integrantes, presupuestos, metodología) y una pregunta en torno a la cual gira todo el capítulo ¿es posible construir una memoria nacional sobre el conflicto armado que no sea una verdad oficial?

El tercer capítulo, Las memorias que seremos -nombre que parodia el título de un libro de Héctor Abad Faciolince llamado El olvido que seremos- se ocupa del contenido de los informes del $\mathrm{GMH}$, en especial el informe general sobre el conflicto, ;Basta ya! Colombia: memorias de guerra y dignidad. Se examinan allí desde la estructura formal que compone los informes, hasta los sentidos promovidos y los tipos de interpretaciones que se construyen, así como las estrategias discursivas y retóricas y algunas de las críticas que se han formulado sobre la producción del GMH.

\section{De la dicotomía historia/memoria a la memoria histórica}

Los procesos de memoria que se están llevando a cabo actualmente en Colombia combinan, de algún modo, el "tiempo corto" y el tiempo de "coyuntura" que distingue Fernand Braudel (1968, p. 64). El tiempo corto es observable en el hecho de que estos procesos de memoria surgen a raíz de un "gran acontecimiento" -como podría ser la Ley 975 de 2005, conocida como la Ley de Justicia y Paz ${ }^{6}$ - que supone, entre otras cosas, la expresión de una voluntad política para reconstruir la historia del conflicto, reconociendo un deber de memoria del Estado que implica "el conocimiento de la historia de las causas, desarrollos y consecuencias de la acción de los grupos armados al margen de la ley" (República de Colombia, 2005). Es en esta forma de enunciar el deber de memoria -misión encargada al Grupo/Centro de Memoria Histórica el que obliga a tomar en cuenta el período de coyuntura ${ }^{7}$, pues sólo remontándose hasta mediados del Siglo XX es posible comprender las dinámicas, causas y desarrollos de la acción armada y el conflicto en el país.

\footnotetext{
${ }^{6}$ Si bien mediante la Ley de Justicia y Paz se reconoce por primera vez el deber de memoria del Estado, durante la época de su formulación fue duramente criticada por académicos y juristas que sostuvieron que promovía una política de perdón y olvido, especialmente cuando los principios de "verdad, justicia y reparación" -inicialmente contemplados para nombrar la ley- fueron sustituidos por los de "justicia y paz", quedando la verdad y la reparación relegadas a un segundo plano, y ya no como aspectos fundamentales a conseguir mediante su aplicación. (Véase por ejemplo: Uprimy Yepes, R. (2006). ¿Justicia transicional sin transición? Verdad, justicia y reparación para Colombia. Bogotá: Centro de Estudios de Derecho, Justicia y Sociedad; Haugaard, L. (2008). La cara oculta de la verdad. En busca de verdad, justicia y reparación para las víctimas colombianas de la violencia paramilitar. Washington: Grupo de trabajo para asuntos latinoamericanos. [En línea]: Disponible en: http://www.lawg.org/storage/documents/cara\%200culta.pdf (consulta realizada el 5 de octubre de 2011).

${ }^{7}$ Braudel plantea una distinción entre tres tipos de tiempo en la historia: la corta duración, referida a acontecimientos puntuales, de minutos, horas, días o unos pocos años; los períodos de coyuntura que abarca
} 
El trabajo del Grupo/Centro de Memoria Histórica (en adelante GMH), precisa hacer una articulación entre hechos acaecidos hace más de $60 a^{n}{ }^{8} s^{8}$ y ese otro gran acontecimiento del presente -ya no exclusivamente nacional-, que es el boom de memoria en Occidente, descrito y desarrollado acertadamente por Andreas Huyssen en su libro En busca del futuro perdido. Cultura y memoria en tiempos de globalización. Allí, luego de mostrar con el ejemplo del Holocausto la preeminencia del pasado y la construcción de un tropos del trauma que se ha vuelto válido para un sinnúmero de situaciones sociales conflictivas y violentas, señala la relación entre pasado y presente que se impone en la construcción de memorias nacionales:

[...] los debates sobre la memoria nacional siempre están atravesados por los efectos de los medios globales y por su foco en temas como el genocidio y la limpieza étnica, la migración y los derechos de las minorías, la victimización y la imputación de responsabilidades. Por más diferentes y específicas de cada lugar que sean las causas, eso indica que la globalización y la fuerte revisión de los respectivos pasados nacionales, regionales o locales deben ser pensados de manera conjunta; lo que a su vez lleva a preguntar si las culturas de la memoria contemporáneas pueden ser leídas en general como formaciones reactivas a la globalización económica (Huyssen, 2002, p. 21).

La omnipresencia cultural de la memoria y los efectos de visibilización (y tal vez también encandilamiento) que pueden derivarse de ella, ameritan ser analizados bajo la óptica de la historia cultural, con la interdisciplinariedad característica de sus aproximaciones, la cual nos parece, por el momento, la vía más fructífera para abordar nuestro tema de interés. Desde la óptica que ella nos ofrece es posible pensar en la relación estrecha entre historia y memoria que se ha establecido en las últimas décadas, la cual ya no responde a esa dicotomía radical planteada por Pierre Nora (1984, p. 20-21) en su célebre trabajo sobre los lugares de la memoria, en la que señalaba todo aquello que las opondría:

Memoria, historia: lejos de ser sinónimos, tomamos consciencia de que todo las opone. La memoria es la vida, siempre llevada por grupos vivientes y, en ese sentido, está en evolución permanente, abierta a la dialéctica del recuerdo y de la amnesia, inconsciente de sus deformaciones sucesivas, vulnerable a todas las utilizaciones y manipulaciones, capaz de largas latencias y repentinas revitalizaciones. La historia es la reconstrucción, siempre problemática e incompleta, de lo que ya no es. La memoria es un fenómeno siempre actual, un lazo vivido en presente eterno; la historia, una representación, del pasado. Por ser afectiva y mágica, la memoria sólo se acomoda de detalles que la reafirman; se nutre de recuerdos borrosos, globales o flotantes, particulares o simbólicos; es sensible a todas las transferencias, pantallas, censuras o proyecciones. La historia, por ser una operación intelectual y laicizante, requiere análisis y discurso crítico. La

una década, un cuarto de siglo y, aun, medio siglo. Este tiempo de coyuntura es el de principal interés para los historiadores económicos y políticos. Por último, la larga duración alude a una historia mucho más amplia, de siglos, que permite captar la estructura de los hechos que conectan pasado y presente. (Cf. Braudel, 1968, p. 64 y ss.).

${ }^{8}$ Recuérdese que el 9 de abril de 1948 se ha constituido en una fecha emblemática que, para algunos, marca el inicio de La Violencia, si bien se trata de una fecha en disputa. Gonzalo Sánchez (1991, pp. 223-225), en su libro Guerra y violencia en la sociedad colombiana indica que hay por lo menos tres posiciones dominantes en cuanto al inicio de la violencia: 1) que comenzó en 1948, con el asesinato de Gaitán; 2) que comenzó dos años antes, en 1946, con la caída de la República Liberal y el regreso al poder del Partido Conservador; o 3) que comenzó incluso antes, entre 1944 y 45, justamente durante el gobierno liberal. Cada una de estas periodizaciones privilegia hechos específicos que le dan un sentido particular al conflicto y orientan la manera de entenderlo, con sus respectivas consecuencias no sólo interpretativas sino también políticas. 
memoria instala el recuerdo en lo sagrado, la historia lo deja al descubierto, siempre prosifica. La memoria surge de un grupo al cual fusiona, lo que significa, como dijo Halbwachs, que hay tantas memorias como grupos, que es por naturaleza múltiple y desmultiplicada, colectiva, plural e individualizada. La historia, por el contrario, pertenece a todos y a nadie, lo cual le da vocación universal. La memoria se enraíza en lo concreto, el espacio, el gesto, la imagen y el objeto. La historia solo se liga a las continuidades temporales, las evoluciones y las relaciones de las cosas. La memoria es un absoluto y la historia sólo conoce lo relativo.

En el corazón de la historia, trabaja un criticismo destructor de memoria espontánea. La memoria siempre es sospechosa para la historia, cuya misión verdadera es destruirla y reprimirla.

Estas fuertes palabras, que marcaron durante un período las posiciones en torno al tema, han sido también objeto de debate entre historiadores y según la lectura de Traverso (2013), la historiografía más interesante cuestionó tal antinomia y extrajo de ahí su fuerza. Friedlander, por ejemplo, habla explícitamente de las implicaciones de la memoria en su propia escritura de la historia. Afirma que, en ocasiones, hay voces que surgen del pasado, que de una manera repentina e inesperada rompen y destruyen la pantalla protectora tras la cual el historiador se había escondido. Es la función de la memoria, que afecta también al historiador. Por ello, el panorama es bastante más complejo de lo que se desprende de las palabras de Nora: no hay solamente un testigo que recuerda y un historiador que analiza, sino que ambas posiciones se entremezclan.

Para Traverso (2013) se está asistiendo a la emergencia de la memoria y a lo que podríamos llamar un momento memorial: la invasión del espacio público por la memoria. En las ciencias sociales se habla de un cambio de paradigma: de la noción de sociedad como concepto central al paradigma de la memoria: "Esto coincide con una puesta en discusión de la historia, una mutación historiográfica, una crisis de la disciplina histórica como escritura e interpretación del pasado". Hartog (2012) va a referirse también a ese viraje entre los lugares de la historia y la memoria, pero afirmando que la última ha sido revestida casi de la misma pretensión de verdad o palabra última que alguna vez se le confirió a la Historia. Una muestra contundente del lugar preeminente de la memoria en la actualidad, la ofrece el reciente surgimiento de leyes de memoria histórica (en España, por ejemplo) y, en el caso colombiano de un Grupo/Centro con esta misma denominación. Este hecho es bastante llamativo porque plantea una fusión entre historia y memoria en la que el lugar predominante es ocupado por la memoria, quedando la historia subordinada a ella, en un lugar de adjetivación. La otrora distinción sustancial entre historia y memoria ha sido diluida. Si se habla de una memoria histórica, se está hablando de la memoria de un pasado que está vigente, que actúa y habita en el presente, pero siendo a la vez un pasado que ha empezado a tomarse como historia, algo acerca de lo cual se puede hacer historia aunque todavía esté actuando en nuestro presente.

\section{La memoria del conflicto armado colombiano en el discurso oficial}

Nuestra pregunta por la memoria y el olvido en el discurso oficial sobre el conflicto armado colombiano tomará como foco de análisis los informes del GMH sobre el conflicto, en especial el informe general sobre el conflicto armado, titulado ¡Basta ya! Colombia: memorias de guerra y dignidad. Este, al igual que los más de veinte informes presentados desde el 2008 hasta la fecha, son productos oficiales y culturales, reflejan una metodología específica de trabajo y responden a un contexto político y social que del que los investigadores son parte, a la vez que lo investigan. 
Justamente las condiciones de producción de las leyes 975 y 1148, por las que se crea, regula y modifica el Grupo de Memoria Histórica, y los informes elaborados por dicho grupo desde el año 2007, serán centrales en el análisis que pretendemos realizar, con el fin de dar cuenta del contexto en el que surgen y hacer un seguimiento de sus transformaciones en la medida en que estas producciones discursivas sobre el conflicto empiezan a ocupar un lugar en la escena pública, siendo a su vez objeto de análisis las formas y estrategias empleadas por el Estado y el GMH para dar a conocer y poner en circulación el material producido a lo largo de los últimos años.

Al hablar de estos informes como un producto oficial, hacemos referencia a su carácter estatal e institucional: no se trata de publicaciones aisladas e independientes, sino que cada informe hace parte de una estrategia de gobierno para dar cumplimiento a un mandato específico sobre el deber de memoria del Estado que comenzó a regir formalmente a partir de la sanción de la Ley de Justicia y Paz, proceso que unos años después, en 2011, adquirió nuevos e importantes matices con la aprobación de la Ley 448 (Ley de víctimas y restitución de tierras). Con ella se ampliaron las funciones del $\mathrm{CMH}$, el cual ya no se ocupará sólo de la reconstrucción y explicación de las causas y desarrollo de los grupos armados ilegales, sino que también gana autonomía y recibe el encargo de administrar el Programa de Derechos Humanos y Memoria Histórica (cuya creación se estipula en un punto anterior de la misma ley). Un aspecto llamativo de esta ley (que será objeto de análisis en nuestro segundo capítulo) es que, a pesar de que la realización de los informes acerca de casos emblemáticos del conflicto hace parte de una iniciativa gubernamental -y, en ese sentido, oficial, en tanto está sujeta a una autoridad derivada del Estado-, la Ley es explicita en cuanto a que no se debe construir en ellos una verdad oficial, esto es, una versión contada únicamente desde la perspectiva estatal e institucional de los acontecimientos, sino que para la elaboración de los informes han de ser tenidos en cuenta los testimonios de víctimas, organismos de derechos humanos, organizaciones civiles y, en algunos casos, se incluirán también confesiones o declaraciones de los victimarios, aun si se deja en evidencia que el propio Estado colombiano es co-responsable -por acción u omisión- de algunos de los eventos que en los informes se registran.

Así pues, cuando en el título del proyecto decimos que haremos un rastreo de cómo la memoria y el olvido aparecen en el discurso oficial sobre el conflicto armado colombiano en el pasado reciente, estamos haciendo referencia a los discursos producidos por funcionarios o entidades estatales pero, a la vez, a un análisis que parte de la idea de que esas manifestaciones surgen enmarcadas en un contexto específico y responden a los avatares de un devenir histórico que ha signado tendencias políticas, sociales y culturales que pueden ser evidenciadas en una lectura minuciosa de los informes.

Otro aspecto que resulta importante resaltar a fin de marcar con precisión qué será estudiado aquí y por qué, es la diferencia entre el discurso oficial, que entenderemos aquí como el discurso formalizado e institucionalizado, concretado en leyes, dictámenes o informes oficiales, y los pronunciamientos públicos de funcionarios del gobierno sobre determinados eventos o situaciones. Si bien suelen ser los segundos los que tienen una difusión y circulación inmediata, con rápidos efectos sobre la opinión pública, su incidencia tiende a ser efímera si se compara con los efectos concretos derivados de acciones oficiales. Una acción oficial -la sanción de una ley, la expedición de un decreto, la difusión de un comunicado, la creación de grupos y comisiones de distinta índole- dan cuenta de la posición oficial del Estado (y los gobiernos que lo encarnan en cada período) como conjunto, mientras que las declaraciones públicas de funcionarios no siempre se dan en dispositivos en los que su palabra está revestida de la fuerza simbólica de su cargo, dando cuenta de una posición que, en tanto personal, no tiene carácter oficial. Un mismo 
presidente puede, por ejemplo, declarar en entrevistas o ruedas de prensa que las razones del conflicto armado son estas o aquellas -según su punto de vista personal- $y$, al mismo tiempo, promulgar una ley que ha sido previamente debatida en el Congreso de la República en la que se ordena la creación de un Grupo de Memoria Histórica que tiene como función encargarse de investigar las causas y efectos de dicho conflicto. Lo que dijo en la entrevista tal vez sea difundido por varios medios de comunicación y tenga un impacto social y político inmediato de intensidad variable, pero la creación de un Grupo de Memoria Histórica tendrá consecuencias concretas, como la conformación de un equipo de profesionales encargados de cumplir con el objetivo trazado, la asignación de un presupuesto que lo haga posible y la producción de informes y materiales didácticos y audiovisuales que pueden ser objeto de análisis académicos y debates públicos de más hondo alcance. Esta diferenciación, por sutil que parezca, es fundamental desde el punto de vista del análisis del discurso que pretendemos realizar, puesto que implica el reconocimiento de que en el campo político (que es donde se asienta la posibilidad de un discurso oficial) el discurso tiene propiedades performativas (Austin, 1962), lo cual quiere decir que cuando alguien ostenta una investidura (en tanto presidente, comandante de las fuerzas armadas o funcionario público en general) y actúa dentro de un marco de condiciones específicas en las que su cargo le confiere potestades que no posee por fuera de estas, aquello que dice no se limita a dar una información o enunciar una convicción personal, sino que tiene consecuencias inmediatas, se constituye en un acto. Fue John Austin (1962), en su célebre ciclo de conferencias publicado bajo el título Cómo hacer cosas con palabras, quien definió ese tipo particular de actos de habla que denominó performativos o realizativos, y que caracteriza como aquellos que no describen o registran nada, no son verdaderos o falsos y cuya mera expresión implica la realización de una acción (jurar, prometer, bautizar, legar, apostar, por ejemplo). Lo que sostenemos, entonces, no es que ambos tipos de pronunciamientos (los informales y los oficiales) sean excluyentes entre sí o que sólo uno de ellos tenga efectos políticos. Lo que sí pretendemos es hacer énfasis en el tipo de implicaciones que tiene cada uno y en el hecho de que, en términos de impactos estatales, son aquellos revestidos de un carácter oficial los que -al menos en principio- tienen mayor potencialidad de generar acciones de mayor alcance y duración.

\section{Una historia de la memoria}

Por un afortunado encuentro de intereses, esta tesis de la Maestría en Historia y Memoria de la Universidad Nacional de La Plata, bien podría ser descrita como una historia de la memoria sobre el conflicto armado en Colombia.

Siguiendo a De Certeau (1985, p. 72), partimos del supuesto de que "[... ] la historia forma parte de la «realidad» de la que trata, y [...] esta realidad puede ser captada «como actividad humana», "como práctica»". De este modo, los informes del Centro de Memoria Histórica en tanto objeto central de estudio, son tomados como productos de una actividad humana particular, enmarcada en un contexto cultural específico que condiciona lo que, bajo la forma de informes oficiales, es escuchado, registrado, organizado, y presentado a la sociedad como producto en el cual reconocerse y a partir del cual repensarse.

Los relatos construidos por $\mathrm{CMH}$ a manera de informes, responden necesariamente a una selección y organización de los acontecimientos, plantean hipótesis argumentadas acerca de cómo se gestaron y se desarrollaron, en resumidas cuentas definen una construcción de la trama, expresión que para Ricoeur (1985, pp. 131-132) indica una mediación en tres niveles:

En primer lugar, media entre acontecimientos o incidentes individuales y una historia tomada como un todo. A este respecto se puede decir 
equivalentemente que extrae una historia sensata de una serie de acontecimientos o de incidentes [...]; o que transforma estos acontecimientos o incidentes en una historia. Las dos relaciones recíprocas expresadas por el de y por el en caracterizan la intriga como mediación entre acontecimientos e historia narrada. En consecuencia, un acontecimiento debe ser algo más que una ocurrencia singular. Recibe su definición de su contribución al desarrollo de la trama. Por otra parte, una historia debe ser más que una enumeración de acontecimientos en serie; ella debe organizarlos en una totalidad inteligible, de modo que se pueda conocer a cada momento el "tema" de la historia. En resumen: la construcción de la trama es la operación que extrae de la simple sucesión la configuración.

En segundo lugar, la construcción de la trama integra juntos factores tan heterogéneos como agentes, fines, medios, interacciones, circunstancias, resultados inesperados, etc. $[. .$.

La trama es mediadora por un tercer motivo: el de sus caracteres temporales propios. Por generalización, ellos nos autorizan a llamar a la trama la síntesis de lo heterogéneo.

Situándose en la perspectiva de Ricoeur, es posible entonces interpretar la narrativa propuesta por el GMH como la elaboración de una historia basada en la memoria en tanto ella teje una narración coherente, ordenada, "completa" a partir de relatos fragmentarios, de recuerdos, noticias, expedientes judiciales, en una integración que concatena actos de individuos y de grupos (tanto armados como estatales y civiles) para otorgar un sentido a lo que se está contando. De alguna manera, nos encontramos ante un artificio que reúne episodios cronológicamente coincidentes con otra clase de ordenamiento que ya no es cronológico sino lógico, y que es el que permite a Ricoeur describir la tercera forma de mediación de la trama como una síntesis de lo heterogéneo.

Un trabajo previo de María Teresa Uribe y Liliana López (2006) que se enfoca en el análisis de las formas discursivas en que son planteadas y justificadas tres de las más grandes guerras civiles del Siglo XIX en Colombia ${ }^{9}$, aporta elementos metodológicos que son también pertinentes en nuestro análisis. Mientras ese trabajo se ocupa de las palabras de la guerra, tal como queda establecido desde el título de su obra, el nuestro podría caracterizarse como una búsqueda de las palabras de la memoria, si bien es preciso reconocer que esas memorias son también memorias de guerra, de conflicto armado. En ese sentido, su justificación acerca de por qué toman la narración como objeto de análisis por encima de las guerras como evento, responde a intereses muy similares a los que determinaron nuestra elección de hacer un seguimiento del discurso oficial sobre el conflicto armado en años recientes:

[...] el objeto de indagación en este texto, no es la guerra como evento historiográfico; no es la trama episódica de lo acontecido; sino la guerra como evento narrado, argumentado, relatado; esto es, configurado, en el entendido de que va dirigido a un público del cual se esperan reacciones consecuentes de carácter político [...].

Esta descripción puede ser articulada con los planteamientos de Habermas (2000) sobre el uso público de la historia, según los cuales el pasado es reinventado permanentemente en función del presente. Se trata de una representación que se hace seleccionando elementos de la historia, de una imagen del pasado que se construye en el presente, sin existir por

\footnotetext{
${ }^{9}$ A saber, la Guerra de los Supremos, entre 1839 y 1842; la Guerra del Siete de Marzo, en 1951 y la Guerra artesano-militar de 1954. Cf. Uribe, M.T y López Lopera, L. (2010). Las palabras de la guerra. Un estudio sobre las guerras civiles en Colombia. Medellín: La Carreta.
} 
fuera de él. El uso público del pasado siempre es un uso político, pues desde él se construyen identidades (nacionales, políticas). Justamente en ese sentido, es perceptible que el Grupo/Centro de Memoria Histórica ha recibido un encargo de suma importancia, con posibles incidencias sobre la construcción de una identidad nacional que, en lugar de silenciar o desconocer el pasado -y presente- de confrontación armada en el país, construya los modos de entenderla, reconocerla y tramitarla en el discurso social. Por medio de la escritura de la historia -o, más precisamente, de las memorias- del conflicto se está llevando a cabo una tarea que, como también plantea De Certeau, ubica en el lugar que le corresponde a los muertos dejando espacio para los vivos, sólo que, en el caso de Colombia, no se trata de algo tan metafórico como una equiparación entre muerte y pasado, sino de muertos y desaparecidos reales que, por los modos en que han perdido su vida, han dejado un vacío en la existencia de sus seres cercanos, así como una serie de interrogantes para una sociedad en la que la violencia armada ha encontrado un nicho en el cual perpetuarse:

[...] de un modo diferente a como ocurre con otras "tumbas" artísticas o sociales, la reconducción del "muerto" o del pasado a un lugar simbólico se articula aquí con el trabajo que tiene por fin crear en el presente un lugar (pasado o futuro) que debe llenarse, un "deber" que hay que cumplir. La escritura recoge el producto de este trabajo; de esta manera libera al presente sin tener que nombrarlo. Así, puede decirse que hace muertos para que en otra parte haya vivos. Más exactamente, recibe a los muertos producidos por un cambio social, con el fin de que quede marcado el espacio abierto por ese pasado y para que todavía sea posible articular lo que aparece con lo que desaparece. Nombrar a los ausentes de la casa e introducirlos en el lenguaje de la galería escriturísitca, es dejar libre todo el departamento para los vivos, gracias a un acto de comunicación que combina la ausencia de los vivos en el lenguaje con la ausencia de los muertos en la casa: una sociedad se da así un presente gracias a una escritura histórica. El establecimiento literario de este espacio se reúne, pues, con el trabajo que efectuaba la práctica histórica. (De Certeau, 1993, p. 128). 


\title{
CAPÍTULO 1 \\ EL PAÍS DE TODAS LAS LUCHAS \\ Tipos de confrontación y actores armados en Colombia ${ }^{10}$
}

\begin{abstract}
Colombia es un país que tiene esas maneras tan contundentes y crueles de zanjar las desavenencias y progresa en medio de rencillas que han extraviado su punto de partida y es difícil saber cuándo, dónde y por qué se iniciaron. Allí hay un caos funcionando ya sin razones. Además de las muchas que se podrían ordenar, clasificar y esgrimir, se desenvuelven con autonomía mecanismos fuera de control.
\end{abstract}

Jaime Correas, Los falsificadores de Borges

De Colombia suele decirse que es un país sin memoria (Schuster, 2010; Pécaut, 2004). Cuáles son las razones que subyacen a esta afirmación y cómo se relacionan con ella las políticas de memoria, silencio y olvido promovidas desde el Estado como actor principal del campo político, serán algunas de las preguntas que guiarán la presente tesis.

Para responderlas, es importante esbozar un panorama histórico de la violencia en Colombia, puesto que sus orígenes tienen, entre otros, un carácter político y aunque en la actualidad estén en juego otras formas de violencia (como la delincuencia organizada o la derivada del narcotráfico), el contexto conflictivo del país no puede entenderse sin remontarse a las guerras civiles del siglo XIX, la división bipartidista entre liberales y conservadores (heredera de la oposición entre federalistas y centralistas después del proceso de independencia), y la lucha intestina por el poder de la Nación entre las ópticas liberal y conservadora, que por siglos se negaron a reconocer matices y divergencias en el ámbito democrático.

Aunque es un lugar común referirse al 9 de abril de 1948 como el día que marcó el inicio de La Violencia (con mayúscula, para referirse a un período más o menos específico que iría hasta 1965), una mirada retrospectiva sobre la historia de Colombia evidencia una tradición de luchas por tierra, derechos y poder, de las cuales el episodio emblemático del Bogotazo ${ }^{11}$ es una expresión desbordante, mas no la que marca el inicio de las confrontaciones, pues estas venían de tiempo atrás.

\footnotetext{
${ }^{10}$ El presente capítulo, como se verá, es un poco más extenso que los otros dos que componen la tesis. Esto sucede porque se consideró importante hacer una contextualización lo suficientemente amplia y detallada de los antecedentes históricos de lo que se conoce como conflicto armado colombiano, que es el tema central del que se ocupan los informes del Grupo de Memoria Histórica, objeto de nuestro análisis. Teniendo en cuenta que esta investigación se presenta como requisito de grado en un país extranjero, consideramos necesario realizar un panorama que le permita al lector no colombiano tener una idea clara de las situaciones que han hecho posible el origen, continuidad y derivaciones de la confrontación armada en el país, así como el tratamiento que ha recibido por parte de distintos gobiernos y de la academia en general. Sin esta contextualización, sería difícil comprender la producción del Grupo de Memoria Histórica e, incluso, el sentido mismo de su existencia como entidad estatal.

${ }^{11}$ Bogotazo es el nombre que se le da al levantamiento popular que tuvo lugar en la capital del país, Bogotá, tras el asesinato de Jorge Eliécer Gaitán cuando salía de su despacho, ocurrido el 9 de abril de 1948. La revuelta comenzó con el linchamiento del asesino de Gaitán, y continúo con fuertes disturbios en toda la ciudad que se extendieron luego a otros lugares del país.
} 
Desde 1812 -aun antes de que se hubiera concretado en la práctica la independencia de España- y hasta 1902, se sucedió una serie de guerras civiles, que inició con la denominada Patria Boba ${ }^{12}$ y culminó con la Guerra de los Mil días ${ }^{13}$ y la pérdida del estado federal de Panamá. No nos detendremos aquí en la descripción de estas guerras, pero sí señaláremos que sus causas y principales actores tuvieron fuerte incidencia ideológica y partidista, una lucha por formas de gobierno opuestas en sus medios y en sus fines, que hicieron del siglo XIX uno de los más convulsionados de la historia de Colombia, al menos en lo que a guerras propiamente declaradas se refiere. Según Jorge Holguín: "nueve grandes guerras civiles generales, catorce guerras civiles locales, dos guerras internacionales, ambas con el Ecuador; tres golpes de cuartel, incluyendo el de Panamá, y una conspiración fracasada" se dieron entre 1830 y 1903 (Holguín, 1908, pp. 143-144). Debido a la alternancia del poder que se fue dando entre estas sucesivas guerras, se proclamaron durante el período siete constituciones que iban imponiendo al país un cariz federalista o centralista, laico o católico, de amplias libertades o grandes represiones, dependiendo del partido que se ubicaba en la presidencia y que regían por un tiempo variable. Álvaro Tirado Mejía afirma, no sin ironía, que esto dio pie "a que se debatieran temas divinos y humanos: el federalismo y el centralismo, la separación de la Iglesia y del Estado, la enseñanza laica o confesional", todo lo cual servía "de motivo para que brillantes ideólogos con brillante argumentación dieran las razones ideológicas por las cuales se debía adoptar una política" (Tirado Mejía, 1995, p. 12). En términos prácticos, además del clima de zozobra y los miles de muertos que dejaron las sucesivas guerras, "el debate sobre asuntos tan genéricos como el centralismo o el federalismo, se concretizaba en la mayor o menor influencia que las oligarquías regionales podían adquirir para resolver en su beneficio el problema agrario y para disponer con mayor libertad del poder regional” (Tirado Mejía, 1995, p. 12).

Entre 1902 y 1948, el ambiente guerrerista se atenuó un poco y se vivieron períodos de relativa calma (Sánchez, Díaz y Formisano, 2003) con gobiernos hegemónicos de ambos partidos: de 1886 a 1930 se mantuvo en el poder el partido Conservador, y después de esa fecha y hasta 1946, el país estuvo en manos del Partido Liberal.

Este panorama amplísimo de las guerras civiles en Colombia tiene como fin evidenciar que el clima de tensión y violencia política ha sido una constante en el país y, por lo tanto, la elección del 9 de abril de 1948 como fecha emblemática que señala el inicio de una etapa denominada justamente "La Violencia" es, como toda operación que torna emblemática una fecha, una construcción que busca transmitir ciertos sentidos (Jelin, 2002). Su preponderancia en la historia y la memoria nacionales no puede hacernos perder de vista que los sucesos desatados ese día se enmarcan en una cadena de tensiones de muy vieja procedencia. Adherimos aquí a la perspectiva de Pécaut:

La persistencia de la violencia social y política demuestra muy bien la intensidad de las divisiones sociales y políticas. El término "Violencia", como se sabe, ha servido de nombre propio para designar esa especie de guerra civil, conjunción de fenómenos muy heterogéneos, que produjo 200.000 muertos en el curso de los años 1944-1965.

\footnotetext{
${ }^{12}$ Con este nombre, acuñado por Antonio Nariño, suele conocerse el primer período de la República de Colombia a raíz de las disputas entre federalistas y centralistas que comenzaron a luchar por imponer cada uno una forma de gobierno cuando ni siquiera se había terminado de alcanzar la independencia total de España. (Cf. Llano Isaza, 2007; Mejía Pavoni, 2009).

${ }^{13}$ En el último año del Siglo XIX, bajo la presidencia de Manuel Antonio Sanclemente (del Partido Nacional, posteriormente Partido Conservador), estalló una guerra civil entre liberales y conservadores que dejó un saldo de más de cien mil muertos, según sugieren varios historiadores. Otra de las consecuencias atribuidas a esta guerra es la separación del Departamento de Panamá, el cual se separó de Colombia para conformar un país independiente pocos meses después del fin de la guerra. (Véase: Vélez, 2005).
} 
Este episodio se inserta en realidad dentro de una trama mucho más extensa. La violencia enlaza con las guerras civiles del siglo XIX. Sigue desempeñando un papel central después de 1965, y no hay elecciones en las que no se evoque el riesgo de que se vuelva a generalizar (Pécaut, 1987, p. 17).

Siguiendo esta línea de pensamiento, podemos afirmar que el 9 de abril es, a la vez, expresión del estallido de una crisis social en un momento específico de la historia nacional y advertencia sobre lo que podría volver a suceder de mantenerse las condiciones estructurales que lo hicieron posible en 1948. Así, se trata de una marca tanto de historia como de memoria, en tanto se registra un evento preciso (conocido como "el bogotazo") al tiempo que se lo emplea como memoria ejemplar (Todorov, 2000) que ha sido usada con muy diversos propósitos: desde la amenaza vedada que supone la pérdida de autoridad del Estado hasta su empleo como ejemplo de aquello que no debe volver a repetirse, pasando por el uso de la figura de Gaitán como símbolo de luchas y reivindicaciones populares. En palabras de Jorge Orlando Melo (1998):

\begin{abstract}
El impacto del 9 de abril puede mirarse en dos niveles, separables pero estrechamente entrelazados. Uno es el de las consecuencias que pudiéramos llamar objetivas del hecho: cómo reaccionaron a su muerte los dirigentes del país y los sectores populares, los liberales y los conservadores, los gaitanistas y sus enemigos, los propietarios y los artesanos; cómo fueron desarrollándose los eventos que configuraron la violencia; cómo se fue organizando el país para enfrentar este problema. Por otro lado, con un homicidio contra una persona como Gaitán, que se había convertido en el colombiano más popular, se generaba adicionalmente una representación nacional de carácter mítico: la memoria de Gaitán, de su muerte y de los hechos del 9 de abril, se convirtió inevitablemente en un factor mismo de los acontecimientos históricos posteriores.
\end{abstract}

Si bien ningún historiador desconoce la importancia de este día dentro del marco general de la historia nacional, su uso como fecha emblemática del comienzo de La Violencia sí ha sido problematizado y pueden rastrearse varias posiciones en cuanto a este origen. Gonzalo Sánchez, en su libro Guerra y violencia en la sociedad colombiana (1991, pp. 223-225), indica que hay por lo menos tres: 1) que comenzó en 1948, con el asesinato de Gaitán; 2) que comenzó dos años antes, en 1946, con la caída de la República Liberal y el regreso al poder del Partido Conservador; ó 3) que comenzó incluso antes, entre 1944 y 45, justamente durante el gobierno liberal. Cada una de estas periodizaciones privilegia hechos específicos que le dan un sentido particular al conflicto y orientan la manera de entenderlo, con sus respectivas consecuencias no sólo interpretativas sino también políticas. Cada posición, como se desprende de su mera descripción, apunta a responsabilizar a uno u otro de los partidos tradicionales como desencadenante de la época de terror generalizado que tuvo lugar durante la segunda mitad del Siglo XX.

En cualquier caso, el asesinato de Gaitán, sea que se tome como hecho de apertura o como hito de gran importancia en el estallido de violencia generalizada que se vivió en el país por un extenso período, es símbolo de una transición entre guerras declaradas, con bandos claramente delimitados, y un ambiente más amplio e inespecífico de cruentas confrontaciones (La Violencia) que, a su vez, se convierte en antesala de lo que a partir de la década de los años ochenta ${ }^{14}$ comenzó a llamarse conflicto armado interno, dándole

\footnotetext{
${ }^{14}$ Una búsqueda avanzada en los catálogos públicos de las bibliotecas del Banco de la Repúblicas, Luis Ángel Arango, Universidad de los Andes y Universidad de Antioquia, evidenció que recién mediando la década de los ochenta comienzan a aparecer artículos y trabajos académicos que usen en sus títulos la expresión "conflicto armado" en Colombia. A partir de los noventa, se hace notorio el incremento de trabajos relacionados con este tema, ascenso que se mantiene y sigue siendo observable en la actualidad.
} 
nuevos matices a unos enfrentamientos que no podían ser entendidos meramente como una continuidad de aquellos que habían sido aplacados por el acuerdo bipartidista del Frente Nacional. En los apartados siguientes se procurará desarrollar esta afirmación y esbozar un panorama del conflicto armado en el pasado reciente. Guerra, Violencia y conflicto armado son nociones ampliamente usadas por el Grupo de Memoria Histórica en sus informes, razón por la cual una exploración de los enfrentamientos que se han presentado a lo largo de la historia del país y las formas en que han sido nombrados y presentados se torna una tarea ineludible antes de pasar al análisis de las producciones del $\mathrm{GMH}$.

\subsection{Lo que no se quiere, se mata. Democracia y exclusión en la política colombiana}

Hablar de la lucha partidista es un lugar común -pero necesario- a la hora de entender la dinámica de la violencia y el conflicto en Colombia. Como vimos, dos han sido los partidos tradicionales relacionados con esa lucha: el conservador y el liberal, cada uno heredero de tendencias opuestas que comenzaron a perfilarse desde los primeros momentos de la independencia, relacionadas tanto con la forma de gobierno -centralista o federalistacomo con el manejo de la economía, la educación y las libertades individuales. Durante el siglo XIX, la división entre estas dos tendencias fue algo común a varios países recién independizados, pero en Colombia esa división se mantuvo a lo largo del siglo XX y no ha sido del todo superada en la época actual.

Para el historiador Álvaro Tirado Mejía (1996), las diferencias entre los partidos liberal y conservador no son tan estructurales como se ha pretendido mostrar, pues ambos son creados bajo la influencia del ideario liberal europeo característico de los años de su conformación (1848 y 1849, respectivamente), aspecto que fue un denominador común en la mayoría de los nacientes partidos políticos en América Latina pero que, como señala Bethell (2001, p. 8), constituyen una paradoja, pues se trata de una "adaptación del liberalismo a unas sociedades muy estratificadas que tenían economías subdesarrolladas y una tradición política de autoritarismo, así como la influencia del positivismo en las élites gobernantes e intelectuales". En el caso colombiano hay que resaltar, sin embargo, que hay una marcada diferencia entre quienes conforman los partidos y los intereses prácticos que los animan: los conservadores deben su nombre justamente a su interés por conservar el estado de cosas heredado de la colonia y por eso estuvieron entre sus fundadores esclavistas, burócratas, terratenientes, militares de alto rango y clérigos; en cuanto al partido liberal, sus principales adeptos eran aquellos menos favorecidos por el poder tradicional y a quienes les convenía una transformación profunda del orden estatal, como los comerciantes, los esclavos, los indígenas y los artesanos.

Más allá de la ideología de base, Tirado Mejía (1996) subraya el problema religioso como el real punto de separación entre los partidos. La injerencia de la Iglesia llegaba para la época a todas las áreas relevantes del poder político, desde la acumulación de bienes hasta la educación. Las simpatías y alianzas de sus más altos jerarcas estuvieron siempre del lado conservador y, sacando provecho de su amplia presencia en el territorio nacional y de la fuerte ascendencia que tenían sobre una población mayoritariamente rural, con bajo nivel educativo y férrea devoción católica, hicieron del púlpito un espacio de proselitismo, a veces sutil, a veces directo e incendiario. De este modo, la Iglesia jugó un papel central tanto en las guerras declaradas y los enfrentamientos sin cuartel entre seguidores de uno y otro partido, como en las contiendas electorales. Su influencia llegó a tal punto que, según relata Bushnell (1994, p. 230), en 1913 un sacerdote antioqueño declaraba ante sus fieles: «Hombres y mujeres que me escucháis, tened presente que el parricidio, el infanticidio, el 
hurto, el crimen, el adulterio, el incesto, etc., etc., son menos malos que ser liberal, especialmente en cuanto a las mujeres se refiere».

En un país con escasa o nula formación política una institucionalidad débil y una iglesia omnipresente, no es extraño que las filiaciones partidarias estuvieran motivadas más por simpatías sin fundamento o por tradición familiar que por una adhesión genuina a tal o cual discurso (Tirado Mejía, 1996; Duplat, 2003). Pero si la adhesión ideológica no era genuina, la partidaria lo era en extremo, existiendo familias o incluso zonas enteras que profesaban fidelidad a uno de los partidos y estaban dispuestas a luchar a muerte contra quienes pertenecían al bando contrario. Esta caracterización que aparece una y otra vez en los historiadores de Colombia, coincide con la típica visión de quienes escriben la historia política de América Latina, que suelen sostener que en el continente los sectores populares fueron principalmente actores pasivos que se movían al vaivén de los caudillos, buscando su protección. Si bien esto puede tener algo de verdad porque era, de hecho, lo que pretendían y fomentaban las clases dominantes por doquier, no pueden desconocerse las protestas, reclamos e inconformidades crecientes que dieron origen a organizaciones sociales y políticas, no siempre armadas, que pugnaban por un reconocimiento de derechos y un mayor bienestar y posibilidad real de participación política de toda la población. Este hecho es coherente con la inestabilidad y los vicios de las democracias latinoamericanas, que han pasado por largos períodos de «democracias oligárquicas» (Hartlyn y Valenzuela, 1994), lo cual es en sí mismo una contradicción en los términos, puesto que, idealmente, oligarquía y democracia deberían ser entendidas como contrarias. Sin embargo, Latinoamérica los ha visto operar de manera conjunta en una semidemocracia que ha limitado el constitucionalismo, ha manipulado o cooptado los procesos de participación y que, en no pocos casos, ha recurrido al fraude para llevar al poder a los miembros de las élites que tradicionalmente lo han detentado.

Uno de los estudios más reconocidos sobre los procesos de violencia y conflicto en Colombia -los cuales están estrechamente vinculados con la situación de la democracia en el país- es La violencia en Colombia el cual fue elaborado con base en los hallazgos de la Comisión Investigadora creada durante la Junta Militar de 1957 que precedió el gobierno de alianza conocido como Frente Nacional para estudiar las causas y dimensiones de los enfrentamientos bipartidistas. Allí se evidencian prácticas que van desde el hostigamiento y el fraude electoral, hasta terribles formas de asesinato y exhibición de cadáveres que se propagaron por campos, pueblos y ciudades. Guzmán Campos, Fals Borda y Umaña Luna (1962) señalan como antecedentes históricos de La Violencia los años de 1930, 1946 y 1948, en cada uno de los cuales se produjeron transiciones significativas: en 1930, el triunfo del Partido Liberal para ocupar la presidencia, rompiendo con un largo período de gobiernos conservadores (Melo, 1996); en 1946, tras un continuum de hegemonía liberal, retornaron los conservadores, lo que azuzó nuevamente las rencillas partidarias. En el año de 1948, el asesinato del líder liberal Jorge Eliécer Gaitán -crimen que hasta la época presente no se ha esclarecido- marcó un punto de no retorno en la exacerbación del ánimo belicoso, desatándose una furia sin precedentes en todo el territorio nacional que cobró cientos de miles de vidas y que, por su la naturaleza desbordada, recibió el nombre genérico y en mayúscula de La Violencia.

A partir septiembre de 1946, "los días discurren bajo una gran tensión política y social con marcada tendencia a la anarquía, reflejada en una creciente ola de huelgas y paros solidarios que se extienden por todo el país" (Guzmán et. al, 1962, p. 47). En el departamento de Caldas, importante bastión del partido conservador, se decomisa un arsenal de armas y en dos de sus municipios comienzan a operar los primeros grupos violentos que vendrán a ser conocidos en años posteriores como "pájaros". Estos 
constituyen las primeras agrupaciones paramilitares en Colombia, pues solían operar de la mano de las fuerzas armadas regulares, concretamente durante gobiernos conservadores. De hecho, se ha sostenido que uno de sus principales organizadores era Laureano Gómez, figura central de este partido y presidente de Colombia hasta 1953, cuando fue derrocado por el general Rojas Pinilla, en el único golpe de estado que se ha presentado en la historia colombiana.

Una editorial de la Revista Semana ${ }^{15}$ en 1947 pone en evidencia el estado de cosas en el país en los meses previos al asesinato de Gaitán:

\begin{abstract}
¿Hay, como parece desprenderse de las informaciones de los diarios, una ola de violencia? No. Pero, sin duda, un extranjero que quisiera informarse sobre la situación actual de Colombia, al pasar una revista sobre la prensa del país, la creería al borde de una catástrofe o en el filo de una revolución. Los colombianos, en cambio, no nos alarmamos. ¿Por qué? ¿Nos es indiferente que cada 24 horas se registre un nuevo hecho de sangre, atribuido a luchas políticas? No. No podemos haber llegado a ese grado de insensibilidad. Algo debe ocurrir, sin embargo, para que, cristianos viejos, no demos la importancia que se merece a una situación semejante. Es que no aceptamos esas versiones como se presentan. $\mathrm{Ni}$ los conservadores asesinados por los liberales, ni los liberales asesinados por los conservadores provocan nuestra alarma con nuestra indignación, porque todos esos informes son recibidos con un considerable descuento inicial. Esperemos, dicen las gentes, a ver cómo pasaron las cosas. Y eso -cómo pasaron las cosas- no se sabe jamás. Lo único cierto es que hay algunos colombianos muertos, heridos, asaltados, víctimas de la violencia y la inseguridad. Los partidos que coléricamente se disputan la palma del martirio contribuyen decisivamente a que los hechos vuelvan a provocarse, a que haya impunidad, a que la criminalidad ocasional se tape con sus banderas y levante testigos para amparar a los ofensores o derivar la responsabilidad hacia personas inocentes". (Revista Semana, vol 1, \#13, enero de 1947, pp. 4-5)
\end{abstract}

Traemos esta extensa cita no sólo porque es un buen reflejo de las tensiones de ese momento sino también porque son muchas sus similitudes con la situación actual y, quizá, con cualquier período de la historia nacional en los años posteriores a su publicación. Si se omite la alusión a los partidos y se sustituye por políticos en general, guerrilla, narcos o paramilitares, las mismas palabras constituirían una descripción adecuada de años tan alejados entre sí como 1930, 1955, 1990 ó 2003.

Guzmán et. al (1962) proponen una periodización de la violencia en cinco etapas, cada una de las cuales representa una característica específica de los enfrentamientos, desde su comienzo hasta su apaciguamiento:

1. Creación de la tensión popular, de 1948 a 1949

2. La primera ola de violencia, de 1949 a 1953

3. La primera tregua, de 1953 a 1954

4. La segunda ola de violencia, de 1954 a 1958

\footnotetext{
${ }^{15}$ Semana es una revista colombiana de actualidad y política fundada en 1946 por el expresidente Alberto Lleras Camargo. Su pretensión era "crear una revista independiente, sin ningún color político, que llenara el vacío de análisis dejado por los periódicos, muy ocupados en la noticia del día a día" (Tomado del blog Historia de la prensa colombiana). La revista cerró, en su primera etapa, en 1961. En 1982, Felipe López Caballero -hijo y nieto, respectivamente, de los expresidentes Alfonso López Michelsen y Alfonso López Pumarejo-, retomó este proyecto periodístico con similares propósitos y desde su refundación es una de las revistas más influyentes para el debate y la formación de opinión pública en Colombia.
} 


\section{La segunda tregua, en 1958}

La primera etapa, como se ha insistido, corresponde a la exaltación de las luchas partidarias que comienza con el emblemático bogotazo, cuya estela de violencia se extiende por todo el país durante casi un lustro. En 1953, con la toma del poder por parte del general Rojas Pinilla, se alcanza una primera tregua basada en indultos y amnistías que, como veremos más adelante, han sido la estrategia privilegiada $-y$, según parece comprobar la historia, ineficaz- de los gobiernos colombianos para alcanzar "la paz", como si esta pudiera ser definida únicamente en términos de ausencia de confrontación armada. Rápidamente, en 1954, se desata otra cruenta etapa, esta vez motivada por las acciones del ejército en contra de la población civil. En La Violencia en Colombia, se explica:

Un pueblo tan recientemente lesionado captó de inmediato el sesgo del grupo oficial y como solo faltaba una chispa para reiniciar el mal extinguido incendio, bastaba que se presentara un hecho, un mínimo pretexto, para desatar de nuevo la catástrofe.

$\mathrm{Y}$ este hecho, este minúsculo pretexto acaeció cuando elementos de tropa masacraron a varios campesinos el 12 de noviembre de 1954.

$[\ldots]$

Todo se sintetiza en un hecho escueto y brutal:

Ejército y pueblo se enfrentaron otra vez a muerte. Este período de violencia fue más bárbaro incluso que el anterior (Guzmán et. al., 1962, pp. 120-121).

En 1958, los partidos liberal y conservador deciden hacer un pacto, conocido como Frente Nacional, para poner fin tanto a las confrontaciones entre sus seguidores como a los enfrentamientos protagonizados por el ejército. La estrategia consiste en establecer un período de 16 años de alternación en la presidencia, garantizando una participación equitativa de ambos partidos en los distintos cargos gubernamentales en todo el país. El éxito de esta alianza es considerable si se analizan los años posteriores en términos de la reducción en las cifras de muertos y de cierta estabilización de la política, que empezó a tramitar por vías diferentes a la simple represión las protestas y demandas sociales (Jaramillo, 2011, cap. 3). Sin embargo, esa alianza partidaria acentuó lo que desde muy temprano había comenzado a perfilarse, y es que estos partidos dominantes estaban poco dispuestos a admitir otros competidores en la escena política. Si bien desde los inicios de la tradición electoral era evidente el poco respaldo y la persecución a agrupaciones distintas, con el Frente Nacional la exclusión se hizo explícita y esto dio pie a nuevos levantamientos, en este caso de organizaciones y movimientos que vieron en la lucha armada la única vía posible para alcanzar en algún momento el acceso al poder.

El triunfo de la revolución cubana en 1959, muy cercano a la instalación del Frente Nacional, alentó el surgimiento de organizaciones político-militares en muchos países latinoamericanos, y Colombia no fue la excepción. Desde la perspectiva de Alan Angell, el efecto de la revolución se dio en doble vía: tanto la izquierda como la derecha se movilizaron en torno a lo que estaba desatando en el continente el triunfo de Fidel Castro y sus seguidores:

Los debates que se entablaron en la izquierda latinoamericana a raíz de la revolución cubana no fueron simplemente teóricos. Durante los primeros años sesenta en casi todos los países latinoamericanos se organizaron grupos de guerrilleros, algunos de los cuales eran importantes mientras que otros, no. Pero las «lecciones» de Cuba no afectaron únicamente a la izquierda. Los Estados Unidos y la derecha política latinoamericana estaban decididos a impedir otra Cuba. Entre marzo de 1962 y junio de 1966 hubo nueve golpes militares en América Latina. En por lo menos ocho de ellos el ejército actuó de manera preventiva y derrocó a un gobierno que, al modo de ver de 
los militares, era demasiado débil para tomar medidas contra movimientos populares o "comunistas», o contra gobiernos a los que se acusaba de desear, ellos mismos, llevar a cabo reformas subversivas, como ocurrió en la República Dominicana o en Brasil. (Angell, 1997, p. 103).

Para el caso colombiano, es importante resaltar que desde mucho antes de 1959 habían comenzado a surgir grupos de autodefensa campesina (que posteriormente se convirtieron en guerrillas comunistas y liberales) que reclamaban un reparto más equitativo de la tierra y mejores condiciones de vida y de trabajo. Democracia precaria y disputas por la tierra han sido, desde el inicio, nodos articuladores de la violencia y el conflicto armado en Colombia, problemáticas que persisten -con variaciones, por supuesto- hasta nuestros días y a los que vino a sumarse el narcotráfico desde la década de los años ochenta.

\subsection{Principales actores del conflicto armado colombiano}

Hecho este breve recorrido por las luchas partidarias, es importante, para terminar esta contextualización de las confrontaciones armadas en Colombia, describir los principales momentos y actores en la configuración de esta nueva categoría, pues la noción de conflicto armado parece estar directamente conectada con la aparición en escena de grupos armados contrarios al régimen bipartidista, sus luchas intestinas y posterior pacto de blindaje del poder ${ }^{16}$.

Tal como se esbozó líneas atrás, aunque suele hacerse énfasis en las razones partidistas como núcleo de los enfrentamientos, detrás de estas había otras inconformidades más básicas, relacionadas con las condiciones de vida y de trabajo de una población que, para principios y mediados del siglo XX, era eminentemente rural -y pobre-. La desigualdad ha sido otra de las tantas constantes de la nación colombiana y uno de los ámbitos en los que esto es más evidente es en la posesión de la tierra: en el año 2012, el Instituto geográfico Agustín Codazzi -IGAC- realizó una investigación sobre la distribución de la propiedad rural en Colombia, en la que se evidenciaron altos índices de concentración en pocos propietarios. En sus conclusiones, señala que "el país, según estos hallazgos, ha mantenido y mantiene aún un continuum de desigualdad estructural en la propiedad rural. Estas tendencias de corriente larga sin duda pesan sustancialmente en los pasivos que el país y su sociedad, especialmente urbana, adeuda a sus sociedades rurales" (IGAG, 2012, p. 72).

Distintos gobiernos -especialmente liberales-, han promovido, a lo largo de los últimos ochenta años, reformas agrarias para transformar este panorama, pero como evidencia el último dato citado, sus resultados han sido escasos.

Absalón Machado (2004), después de hacer un recuento de las reformas que se han promovido desde los años sesenta, señalando sus retrocesos, limitaciones y problemas, concluye que, en la práctica, la situación del campesinado colombiano ha cambiado muy poco y, de hecho, se ha agravado por la compra masiva -y muchas veces forzada- de tierras que han hecho los narcotraficantes, en una especie de contrarreforma agraria.

Hacemos hincapié en la continuidad de esta problemática porque no hay estudio sobre la violencia y el conflicto que no la señale como una de las principales, entre las múltiples

\footnotetext{
${ }^{16}$ En la bibliografía revisada no se califica como conflicto armado a la confrontación bipartidista, sino que suele ser descrita de esa manera o con referencias a La Violencia con mayúscula.
} 
determinantes de los enfrentamientos en el país. Los movimientos guerrilleros en Colombia han sido principalmente de origen campesino mientras que las organizaciones contrainsurgentes han encontrado apoyo y financiamiento tanto en amplias secciones de las fuerzas militares como en élites dirigentes y terratenientes, que han tendido a ver en las demandas populares una amenaza a su estabilidad y crecimiento.

Eduardo Pizarro establece una cronología por fases de la resistencia armada campesina inspirada por el Partido Comunista, la cual estuvo presente en el contexto nacional varios años antes de la consolidación de la guerrilla tal como es conocida del año 1966 en adelante, con la creación oficial de las FARC.

[...] si en América Latina en general la emergencia del movimiento guerrillero estuvo en gran medida determinada por la revolución cubana, en Colombia se debe subrayar que la guerrilla de inspiración comunista nació con una década de antelación. Sus primeros núcleos emergen ya a fines de 1949. Pero la diferencia no es solo temporal. Mientras que los primeros grupos que nacen en el país a raíz del ejemplo cubano, tienen todos una orientación foquista y voluntarista (el MOEC, el ELN, el PCML, las FALN) y un origen principalmente urbano de sectores de clase media radicalizada, las guerrillas comunistas nacen articuladas a la resistencia campesina contra la violencia oficial (Pizarro, 1989).

En esta descripción se perfilan entonces dos actores armados importantes: las fuerzas oficiales y los grupos rebeldes alzados en armas. Correlativas a estos son las agrupaciones que se declaran "contrainsurgentes" las cuales, según distintos investigadores (Guzmán et. al, 1962; García-Peña, 2005; GMH, 2013) han actuado por años de la mano con la oficialidad, a veces incluso con la connivencia explícita por parte del Estado que, en distintos gobiernos, ha promovido la creación de grupos de defensa nacional y protección civil que han recibido entrenamiento por parte del ejército y han sido proveídos de armamento reglamentario, por ejemplo, entre 1965 y 1968; y entre 1994 y 1997 (García-Peña, 2005; Equipo Nizkor, 2007).

A fin de hacer más sencillo el seguimiento de los actores implicados en el conflicto, los presentaremos por separado, señalando algunas de sus principales características, así como eventos relevantes en la relación del gobierno con cada uno de ellos que es importante mencionar en función de nuestro análisis acerca del discurso oficial sobre el conflicto armado colombiano en el pasado reciente. También en atención a este objetivo, no nos detendremos en aquellos grupos que desaparecieron con anterioridad a 1980, pues los informes del Grupo de Memoria Histórica, si bien inician con una contextualización a partir de 1958, se ocupan fundamentalmente de acontecimientos posteriores a 1980. Comenzaremos por hablar de las guerrillas, para pasar luego a una presentación de las fuerzas armadas oficiales, terminando con los grupos paramilitares, todos ellos centrales en la dinámica de un conflicto en el que insurgencia y contrainsurgencia han sido protagonistas.

\subsubsection{Los grupos guerrilleros}

Como ya se mencionó, las primeras autodefensas campesinas tuvieron su origen en el país por lo menos una década antes del triunfo de la revolución cubana, y eran cercanas al Partido Comunista. Tanto el ideario de las autodefensas campesinas de mediados de siglo que no debe confundirse con aquellas surgidas bajo el mismo nombre en la década de los ochenta, las cuales corresponden a grupos paramilitares-, como el de los grupos guerrilleros que derivaron de ellas y otros, de carácter indígena y urbano, se inscriben en las 
tradiciones de izquierda y han reivindicado, por diferentes vías y con distintas estrategias, transformaciones estructurales en el ordenamiento social y político de Colombia.

El caso colombiano, paradigmático ya por lo atípico de su conflictividad social, ha sido descrito por algunos (Chernik, 1988; Pizarro, 1991) como el de una insurgencia crónica que, pese a su perdurabilidad, no ha tenido nunca chance de ganar la pugna contra el Estado y tomarse el poder. Para Pizarro:

[...] un cúmulo de factores incidieron en la incapacidad persistente de la guerrilla colombiana para alcanzar esos objetivos, a pesar de la débil legitimidad de las instituciones políticas. En primer término, la enorme dispersión del movimiento guerrillero que se dividió y se subdividió en múltiples corrientes antagónicas a lo largo de casi tres décadas, encontrando sólo a fines de los años ochenta un incipiente camino para la unidad del movimiento insurgente, mediante la Coordinadora Guerrillera Simón Bolívar. Guerrillas de distinto corte ideológico pero, igualmente, de distinta configuración sociológica (societales, de partido y militares) emergieron en los años sesenta, lo cual difícilmente permitiría encontrar modalidades comunes para una eventual articulación. La gran paradoja fue que la unidad guerrillera, así fuese precaria, se produjo cuando ya su posibilidad histórica entraba en franca bancarrota. [...] En segundo término, las características del país en el momento en que surgió la guerrilla postrevolución cubana, no era el ambiente más favorable para un desarrollo fuerte y acelerado de estos emergentes focos insurreccionales (Pizarro, 1991, p. 2).

Además de estas limitaciones, el autor señala los bajos niveles de organización popular en Colombia (menos del $8 \%$ de los asalariados urbanos y menos del $1 \%$ de los rurales hacen parte de algún sindicato), lo que ha imposibilitado una adhesión contundente a las propuestas guerrilleras. Esto coincide con el análisis que de los estados latinoamericanos hace Graciarena (2000), en el que menciona el poco poder de presión y protesta que puede generarse en países con muchos trabajadores no sindicalizados, cuentapropistas, desocupados o temporarios. Igualmente, la multiplicación de fenómenos violentos y tensiones regionales "le restaron transparencia a la violencia de clara índole política" (Pizarro, 1991, p. 6), pues los distintos grupos comenzaron a llevar a cabo prácticas delincuenciales -tales como el secuestro y la extorsión- para financiarse, lo que, a la larga, terminó por deslegitimar su lucha y hacer que se evaporara la especificidad de la misma.

En el mismo texto que venimos siguiendo, Pizarro (1991) realiza una clasificación de las guerrillas más representativas del país a partir de sus características diferenciales. Señala además, cómo la variedad de grupos ha sido un obstáculo reiterado durante los procesos de paz, pues no todos han tenido el mismo potencial de negociación ni interés de reinserción a la vida civil. Según este autor hay tres clases de guerrillas en las que es posible agrupar a los movimientos con mayor injerencia en la contienda armada durante los últimos cuarenta años. Tales clases se basan en tres rasgos que, reunidos, constituirían un tipo de guerrilla ideal: lo societal (legitimidad popular), lo político (un programa incluyente y amplio de participación social) y lo militar (un aparato armado lo suficientemente fuerte como para derrotar a las fuerzas oficiales y devenir él mismo en ejército regular tras la derrota del enemigo). Ninguna de las guerrillas colombianas combinaría los tres rasgos -como sí lo hizo, por ejemplo, el Frente Sandinista de Liberación Nacional en Nicaragua-, sino que en cada una se hizo más notable uno u otro de ellos, sin que esto quiera decir que los otros estaban ausentes por completo.

El movimiento armado indigenista Quintín Lame -MAQL- sería un ejemplo de la guerrilla ideal societal, en tanto hallaba su razón de ser en la representación de un sector excluido. Las guerrillas societales son una especie de movimiento social armado, "dado que busca 
constituirse en una prolongación de un actor social organizado" (Pizarro, 1991, p. 8). Este grupo estuvo en actividad entre 1984 y 1991, contó con el apoyo del M-19 e hizo parte de la Coordinadora Guerrillera Simón Bolívar, que buscó reunir las acciones e intereses de las distintas guerrillas del país, con poco éxito. En 1989, participó en un proceso de negociación con el gobierno junto con la guerrilla del M-19, desmovilizándose y reintegrándose a la vida política y civil luego de conseguir importantes avances en el reconocimiento y respeto de las comunidades indígenas en la Constitución de 1991, fruto de la Asamblea Nacional Constituyente que fue el corolario de esta negociación.

El Ejército de Liberación Nacional -ELN-, representa un caso de guerrilla militar, que encuentra en el foquismo ${ }^{17}$ su estrategia de acción más importante, siendo una de sus principales limitantes la débil articulación con movimientos sociales. El enemigo que configura es absoluto en sus valores e integral en cuanto a los objetivos, lo que vuelve prácticamente inexistentes las posibilidades de negociación. Tanto el aparato como el proyecto político están subordinados al aparato militar, configurando una tendencia fanática que se deriva directamente del carácter absoluto de los fines perseguidos por el grupo, lo cual se evidencia, para Pizarro (1991, p. 12), en

[...] la negativa del ELN en su etapa eminentemente foquista a apoyar la reforma agraria, considerada como un instrumento reformista que desviaba al campesinado de su único interés real: el poder político. La violencia terminaba siendo ilimitada (lógica de la acción total, de la acción por la acción), ya que su único límite lo constituía la contraviolencia del Estado. La violencia dejaba de tener retorno posible: "patria o muerte".

El ELN es una guerrilla activa aun en la actualidad, aunque su presencia en distintas zonas del país se ha visto menguada por efecto de sus disputas con la guerrilla de las FARC (aunque en ocasiones, también, han operado mancomunadamente), y la acción contrainsurgente tanto del ejército como de grupos paramilitares. Desde la década del noventa ha participado en procesos de negociación con los gobiernos de Ernesto Samper, Andrés Pastrana, y Álvaro Uribe, pero en ninguno de los casos esta negociación ha culminado con éxito. Al momento de escribir este apartado (septiembre de 2013) comienza a discutirse en el país la apertura de nuevos diálogos con el gobierno encabezado por Juan Manuel Santos, que vendrían a sumarse a los que se están llevando a cabo desde fines del 2012 con la guerrilla de las FARC.

Una guerrilla particular por sus características urbanas y su composición mayoritariamente intelectual es la del Movimiento 19 de Abril -M-19-, la cual fue creada por disidentes de las FARC, en reacción a un supuesto fraude en las elecciones presidenciales de 1970, en las que participó como candidato el general Gustavo Rojas Pinilla, en representación de la Alianza Nacional Popular -ANAPO- y como contendor de los partidos del Frente Nacional. Por su carácter urbano han tendido a ser relacionadas con el Movimiento de Liberación NacionalTupamaros, de Uruguay, de quienes efectivamente tomaron como modelo algunas estrategias de intervención, tales como el robo de emblemas de la liberación nacional (la bandera de Artigas, en el caso de los Tupamaros; la espada de Bolívar, para el M-19) y el secuestro de empresarios para obtener financiación de su lucha armada. El M-19 ha sido el

\footnotetext{
${ }^{17}$ En las Actas Tupamaras se describe este mecanismo del siguiente modo: "[... ] consiste en un pequeño grupo de revolucionarios dispuestos al sacrificio, [que] reúne armas, monta un buen sistema de suministros, propaganda, sabotaje y reclutamiento en las ciudades, transformándose así en un «foco» militar y político que catalizará y polarizará todas las rebeldías e irá creciendo en forma inexorable hasta transformarse en ejército, ganar la población, derrotar al enemigo, y apoderarse del poder" (Tupamaros, 2003).
} 
grupo que con mayor insistencia justificó la toma de las armas ante la imposibilidad de participar en la contienda política por la vía democrática, cerrada sobre los dos partidos tradicionales. Su discurso pretendía entonces ser democrático y, en la misma vía que el del Frente Unido de Resistencia Guatemalteca -FUR-, se concebía el levantamiento armado no como una vía para derrumbar y reemplazar al sistema (cosa que sí ocurría con el ELN y con las guerrillas más políticas) sino como una forma de presionar al establecimiento para entablar diálogos y abrir los canales de participación a nuevas alternativas políticas. Pese a que en principio parecía haber una incoherencia entre estos fines y las formas de acción emprendidas (muchas de ellas próximas al foquismo y aun al terrorismo, según Pizarro), lograron, no sin tropiezos, alinear medios y fines llegando a ganar gran aceptación popular en zonas rurales y urbanas, lo que, finalmente, culminó en su desmovilización e inserción en la vida política con candidatos propios tras dos procesos de negociación, el primero a mediados de los años ochenta, durante el gobierno de Belisario Betancur, y el segundo finalizando esa década, con Virgilio Barco como presidente.

Pese que las primeras negociaciones se vieron entorpecidas por acciones y presiones de las fuerzas militares y sectores adversos a los diálogos, y al terrible desenlace de la toma del Palacio de Justicia ${ }^{18}$ llevada a cabo por el M-19 en noviembre de 1985, la voluntad de negociación siguió estando en el horizonte, lo que posibilitó que cuatro años después se firmara finalmente un acuerdo que se mantuvo pese a que el otrora máximo líder de esta guerrilla y candidato presidencial a las elecciones de 1990, Carlos Pizarro Leongómez, fuera asesinado por grupos paramilitares el 26 de abril de ese mismo año. El corolario de esta negociación fue la convocatoria a una Asamblea Nacional Constituyente en la que el M-19 obtuvo 19 escaños por voto popular, consiguiendo participar en la redacción de la constitución de 1991, que sigue vigente -con modificaciones- en la actualidad.

La historia del M-19 es importante para la historia colombiana por varias razones: en primer lugar, se trata del único gran movimiento guerrillero con el que se ha llevado a cabo una negociación exitosa en el país, que dio pie a una participación política activa por vías democráticas. Sin embargo, pese a lo alentador que suena esto en principio, los asesinatos de varios de los líderes más importantes y los constantes hostigamientos de las fuerzas militares a los diálogos entablados en 1984, son clara muestra de la debilidad de la democracia y las tensiones que durante décadas han marcado la relación entre el ejecutivo y las fuerzas militares regulares. Sumado a esto, el hecho de que Carlos Castaño, uno de los principales comandantes de las Autodefensas Unidas de Colombia -asociación de grupos paramilitares que, como se señalará posteriormente, participaron de un proceso de negociación y desmovilización durante el mandato de Álvaro Uribe Vélez-, haya admitido que fue quien ordenó al asesinato de Pizarro ${ }^{19}$ por considerar un peligro que un exguerrillero llegara a ser presidente de la República, indica también la persistencia de la intolerancia a las opciones que se distancian de las tradicionales, y que tuvo su máxima expresión con el exterminio sistemático de los miembros del partido de izquierda Unión

\footnotetext{
${ }^{18}$ La Toma del Palacio de Justicia fue una incursión armada realizada por un comando de guerrilleros del M-19 a la sede del Palacio de Justicia, separada por una plaza de la Casa de Nariño, residencia presidencial el miércoles 6 de noviembre de 1985. La misma fue seguida por la reacción de la Policía Nacional y el Ejército Colombiano, que rodearon el edificio e iniciaron una operación de retoma que terminó el jueves 7 de noviembre de 1985. El M-19 tenía aproximadamente 350 rehenes entre magistrados, consejeros de Estado, servidores judiciales, empleados y visitantes del Palacio de Justicia. La operación de retoma dejó un saldo de 98 muertos, 11 de los cuales eran magistrados de la Corte, y 10 desaparecidos. En 2010, el coronel Alfonso Plazas Vega fue condenado por el caso de las personas desaparecidas, puesto que se logró comprobar que algunas de ellas habían salido con vida del Palacio.

${ }^{19}$ Al respecto, véase el artículo "Yo maté a Carlos Pizarro", de la revista Semana, publicado en noviembre de 2011. Disponible en: http://www.semana.com/nacion/articulo/yo-mate-carlos-pizarro-carlos-castano/48633-3
} 
Patriótica -UP- que representó durante los ochenta y noventa los intereses de la izquierda colombiana, no solamente de las FARC.

Mencionaremos por último precisamente a las Fuerzas Armadas Revolucionarias de Colombia -FARC-, uno de los actores centrales del conflicto, no sólo por su larga trayectoria -comparable a la del ELN- sino porque en los años recientes ha sido erigido, sistemáticamente, como el principal enemigo del Estado, en especial por el discurso del expresidente Álvaro Uribe. Según la clasificación de Eduardo Pizarro, las FARC serían un ejemplo de guerrilla política o de partido, lo que se explica por su vinculación con el Partido Comunista, cuyo programa político condicionó, durante muchos años, su actividad. Además, su discurso, aun en los períodos más expansivos y de inclinación hacia lo militar, ha mantenido una vocación de asunción del poder por la vía de las armas, con el fin de implementar reformas profundas en la estructura desigual de la sociedad colombiana.

Los antecedentes de esta guerrilla pueden rastrearse en el ciclo autodefensa campesina guerrilla móvil - autodefensa - guerrilla móvil que comenzó en 1949, como un llamado de la dirección del Partido Comunista para defenderse de los ataques reaccionarios en zonas rurales donde tenían influencia. Para el año 1961, tenían una presencia importante en varias zonas del sur del país, algo que llegó al conocimiento de algunos políticos y comenzó a ser tratado como problema de capital importancia ante las declaraciones que hiciera en el Congreso Álvaro Gómez Hurtado (hijo del derrocado expresidente Laureano Gómez) denunciando la existencia de «repúblicas independientes» que estaban por fuera del control estatal y bajo la influencia directa de los comunistas. Estos se habían convertido, en el marco de la guerra fría, en objeto de persecución global y, desde 1958, se habían acentuado las acciones en su contra en toda Latinoamérica, con la participación de Estados Unidos. El presidente de la época, Guillermo León Valencia, ordenó acabar con esos «enclaves comunistas», lo que desató una agresiva arremetida militar que propició la transformación de las autodefensas campesinas en guerrillas móviles. Inicialmente se llamaron Frente Sur, en 1964, y a partir del 66 comienzan a usar el nombre con el que siguen siendo conocidas en la actualidad (Fuerzas Armadas Revolucionarias de Colombia).

Como parte de la ofensiva del ejército, se hicieron bombardeos a Marquetalia (Tolima), en el suroccidente del país. Los operativos estuvieron enmarcados, según algunos (Pizarro, 2006; IEPRI, 2006; Gutiérrez et. al., 2006), en el plan LASO (Latin American Security Operation), un "proyecto contrarrevolucionario global para toda América Latina agenciado desde Washington" (Pizarro, 2006). Este plan, del que hay poca información oficial, parece ser un antecedente del -ese sí ampliamente conocido- Plan Cóndor, una coordinación entre las Fuerzas Armadas del Cono Sur que, según señala Serra Padrós (2009, p. 2), “dieron prioridad a las fronteras ideológicas, por arriba, incluso, del efecto funcional de las fronteras políticas", al considerar que "el accionar anticomunista no debía enfrentar barreras". Desde muy temprano, como se ve, las FARC comenzaron a perfilarse como símbolo de todo lo que debe ser perseguido según los designios de la política global promovida por EEUU: el comunismo, durante el período de la Guerra Fría, y el terrorismo, después de los acontecimientos del 11 de septiembre de 2001.

El ataque a Marquetalia ha sido desde hace décadas el mito fundacional de las FARC, y les ha servido para postular que no se constituyeron como guerrilla por iniciativa propia, sino en respuesta a una agresión externa proveniente del Estado colombiano. Igualmente, este argumento ha sido utilizado para marcar diferencias con otras guerrillas -como el ELN y el EPL-, "las cuales habían surgido con base en la iniciativa política de sectores de clase media urbana radicalizados. Frente al voluntarismo y al foquismo guevarista, las FARC aparecían 
como el resultado de una agresión del Estado contra la población campesina" (Pizarro, 2006).

En 2009, Daniel Pécaut escribe sobre la «guerra prolongada» de las FARC, señalando algunas características importantes de esta agrupación. En primer lugar, su longevidad; y en segundo, su cohesión pese a la gran expansión que llegaron a tener. Para dar cuenta de las continuidades y discontinuidades del proyecto de esta agrupación, es posible identificar varias etapas importantes. La primera es la de formación, entre los años sesenta y setenta, en el contexto de las luchas agrarias que estuvieron presentes en el país desde la década del 1920. La segunda es la transformación expansiva en los años ochenta y noventa, que los lleva a buscar fuentes de financiación mediante prácticas que les han costado una fuerte deslegitimación ante la opinión pública: secuestros, extorsiones, uso de armas prohibidas por los protocolos internacionales (como los cilindros de gas) malversación de finanzas locales e incluso narcotráfico. Una tercera etapa sería la supremacía de la estrategia militar, a finales de los años ochenta y durante los noventa, cuando se margina de la tutela del Partido Comunista.

En cuarto lugar, las FARC viven, según Pécaut, una etapa de evidenciamiento de su incapacidad política, tras el fracaso de todas las negociaciones emprendidas con el Estado a lo largo de veinte años, a saber: la de 1982-1986, con el gobierno de Belisario Betancur ${ }^{20}$; los acercamientos con el gobierno de Virgilio Barco y César Gaviria, que no tuvieron éxito porque buscaban, más que negociar, deslegitimar a la guerrilla y devolverle al Estado el lugar central, lo cual era un retroceso ante el reconocimiento que habían obtenido previamente. Por último, está el proceso de paz de casi tres años durante el gobierno de Andrés Pastrana, al que el país le apostó con grandes esperanzas porque todavía estaba vigente la credibilidad en una vía negociada que había producido la desmovilización de las guerrillas del M-19, EPL y Quintín Lame en 1990. Sin embargo, ante los desplantes y extralimitaciones cometidas por las FARC en medio del proceso de negociación, que incluyeron tomas violentas de pueblos, secuestros y el uso de la zona que se había despejado para los diálogos como lugar de entrenamiento y fortalecimiento militar, fueron minando poco a poco la legitimad del proceso, el cual terminó abruptamente tras el secuestro de un senador de la República en febrero del 2002. Este fracaso estrepitoso, la pérdida de legitimidad de las partes ante la opinión ciudadana y un agotamiento generalizado ante los actos violentos de las FARC, facilitaron el posicionamiento de un discurso guerrerista, de mano dura, que fue capitalizado por el entonces candidato Álvaro Uribe y que, desde entonces, ha provocado un clima de polarización tan encendida que los diálogos que se están desarrollando actualmente (2014) en La Habana (con Juan Manuel Santos en la presidencia), son vividos no sólo con gran escepticismo sino en medio de una fuerte oposición de sectores políticos y civiles.

Una quinta etapa estaría asociada a los dos períodos de gobierno de Álvaro Uribe (20022006; 2006-2010), y sería la de repliegue y desmoralización de las FARC tras la persecución

\footnotetext{
${ }^{20}$ Sin embargo, para Marc Chernick, director del programa de estudios andinos y del Amazonas de la Universidad de Georgetown, esta primera negociación no puede considerarse un fracaso total pues, pese a no haber culminado con la firma de la paz con las FARC, introdujo dos elementos cruciales en el discurso político nacional: por un lado, el reconocimiento de la oposición armada como actor político y, en consecuencia, la necesidad de dialogar con ella; por otro lado, la aceptación de que el país debía entrar un proceso de apertura democrática, tal como estaban haciendo varios países de la región en esa época. (Cf. el artículo titulado "Es histórico lo firmado con las FARC", entrevista de Juan Pablo Barrientos a Marc Chernick publicada por la Revista Semana el 29 de agosto de 2013. Disponible en: http://www.semana.com/nacion/articulo/es-historico-hafirmado-farc/355654-3)
} 
sistemática y con grandes éxitos militares de la que ha sido objeto desde el 2002, bajo el amparo de un discurso marcadamente antisubversivo, de cero tolerancia a las guerrillas que, como ya se mencionó, llevó al país a un grado de polarización que bien podría evocar los tiempos de la división partidista. No sólo las fuerzas armadas de la nación se han visto fortalecidas como nunca antes gracias al apoyo financiero y táctico de Estados Unidos, sino que se incrementó también el accionar contrainsurgente de grupos paramilitares que actúan en nombre de la defensa de intereses privados y, muchas veces -según se ha comprobado y se sigue investigando actualmente-, con el apoyo directo o indirecto del ejército y la policía. Según Pécaut (2009, p. 43):

[...] hasta 2004 el debilitamiento de las FARC se debe menos a [la] modernización [de las fuerzas militares] que a las acciones emprendidas por los grupos llamados "paramilitares". Tales grupos existen desde principios de los 80. Pero hacia 1993, comienzan a expandirse y en 1997 se proponen coordinar sus operaciones contra la "subversión" con la formación de las AUC (Autodefensas Unidas de Colombia). Financiados por las redes del narcotráfico y dirigidos por lo demás cada vez con mayor frecuencia por algunos de sus capos más importantes, los paramilitares se concentran en recuperar las regiones que están bajo control de la guerrilla, no enfrentándose con ella de manera directa, sino haciéndole el vacío a su alrededor. El uso del terror contra la población civil, las matanzas sistemáticas y las atrocidades comparables a las de la Violencia, están en la base de su contraofensiva.

En un apartado posterior nos ocuparemos de la caracterización de los grupos paramilitares, su evolución, auge, desmovilización y resurgimiento bajo "nuevas/viejas" modalidades delictivas.

Antes de eso, es importante mencionar que el uso del terror contra la población civil ha sido una estrategia empleada tanto por guerrilleros como por paramilitares, tal como menciona Pécaut en la cita anterior y es documentado por el Grupo de Memoria Histórica (2013) en su informe general sobre el conflicto armado, cuyos hallazgos indican que la confrontación armada en Colombia se da menos entre combatientes y más a través de los ataques e intimidaciones hacia los pobladores. Así, de los 220.000 muertos de los que se tiene registro, y que están asociados al conflicto armado entre el $1^{\circ}$ de enero de 1958 y el 31 de diciembre de 2012 , el $81,5 \%$ corresponde a civiles y el $18,5 \%$ a combatientes de los grupos armados, lo cual quiere decir "que aproximadamente ocho de cada diez muertos han sido civiles, y que, por lo tanto, son ellos - personas no combatientes, según el Derecho Internacional Humanitario— los más afectados por la violencia" (GMH, 2013, p. 32).

\subsubsection{La fuerza pública ${ }^{21}$ del Estado}

Un conflicto armado de carácter político implica siempre al Estado como uno de sus actores, aunque no sea necesariamente desde él que se da origen a las confrontaciones. Dentro del Estado, son las fuerzas armadas (ejército, armada, fuerza aérea) las llamadas a combatir directamente contra las agrupaciones que se alzan también en armas para desestabilizar el poco o mucho orden que se viva en el país. Por tal razón, no puede omitirse hablar de ellas como un actor fundamental dentro del conflicto armado colombiano, máxime en este caso, pues se trata de "una institución que abandona sus funciones constitucionales de la defensa nacional y se ve involucrada, en forma

\footnotetext{
${ }^{21}$ Teniendo en cuenta que la categoría "fuerzas armadas" está asociada únicamente a las fuerzas militares y que, en Colombia, la fuerza civil encarnada por la policía también se ha visto involucrada en el conflicto armado, preferimos usar la noción más amplia de "fuerza pública", que incluye a ambas facciones.
} 
permanente, en los conflictos internos de un Estado". De este modo "termina por constituirse en uno de los actores centrales del juego político” (Pizarro, 1987, p. 5).

Ante el surgimiento temprano de las guerrillas de inspiración liberal y comunista, el ejército colombiano se ve involucrado mucho más tempranamente que otros en Latinoamérica en la ofensiva contra grupos armados rebeldes, lo cual se verá reforzado cuando el impacto del triunfo de la revolución cubana motive el surgimiento de nuevas agrupaciones guerrilleras.

Un aspecto que vale la pena resaltar, pues ha sido objeto de análisis por los estudiosos del conflicto, es la transformación del lugar ocupado por la fuerza pública, especialmente las fuerzas militares, a lo largo de la historia republicana del país. Otro detallado estudio de Pizarro (1987) da cuenta del lugar marginal que tuvieron durante un largo periodo, no sólo porque en Colombia el poder ha estado tradicionalmente centrado en élites civiles y económicas, sino también porque durante los gobiernos liberales, especialmente el de Alfonso López Pumarejo, se las trató con suma desconfianza, pues eran notorias las preferencias conservadoras de extendidos sectores de sus filas.

Por su parte, la policía gozó de ciertos privilegios durante esta administración, lo que suscitó la aparición de tensiones entre ambos cuerpos armados que se hicieron notorios con el estallido del periodo de La Violencia, cuando el control del gobierno había pasado a manos conservadoras. Para Guzmán et al. (1962), la policía fue una de las primeras instituciones en resquebrajarse y empezar a inmiscuirse en acciones irregulares. De acuerdo con Pizarro (1987, p. 7):

\begin{abstract}
El tradicional funcionamiento clientelista utilizado para reclutar a los miembros de la policía y ante todo su alta politización partidista durante la República Liberal, le creó un clima propicio al conservatismo para organizar a su vez y desde el poder una "policía política", que comenzaría a actuar como una suerte de brazo ejecutivo del partido de gobierno, en particular en sus niveles intermedios y bajos.
\end{abstract}

Más que hacer una presentación pormenorizada de las fuerzas armadas en Colombia, interesa señalar aquí algunas características particulares de su relación con el poder ejecutivo, así como las transformaciones que ha tenido y sus niveles de injerencia en el manejo del conflicto. Los antecedentes que acaban de ser esbozados, apuntan justamente a mostrar algunas de estas características, a saber, sus estrechas relaciones con intereses partidistas, a mediados del siglo XX y, sobre todo, su subordinación a las élites civiles. Las fuerzas armadas colombianas no han tenido un papel preponderante en la toma de decisiones políticas, muestra de lo cual es que el único golpe de Estado que se ha presentado en su historia, en 1953, fue preparado por la élite política con dos años de antelación (Pizarro, 1987, p. 36), lo que ha sido descrito como un régimen militar bajo tutoría civil. Otro aspecto llamativo de este gobierno de facto es la negativa inicial de los militares, en cabeza del General Gustavo Rojas Pinilla, a asumir la presidencia, esperando que luego de su intervención esta siguiera siendo ocupada por Roberto Urdaneta (quien fungía como presidente designado ante la ausencia por enfermedad de Laureano Gómez, cuyo derrocamiento era el objetivo específico del golpe), lo que da cuenta de la poca voluntad autoritaria de los dirigentes de las fuerzas armadas, que aceptaron a regañadientes, pero con gran júbilo popular, hacerse cargo del quebrantado orden de la Nación con relativo éxito, en especial durante el primer año de la dictadura. Para Pizarro (1987, p. 37): 
Esta posición subordinada que le acordó a las Fuerzas Armadas el orden político elitista de la primera mitad del siglo, sus limitaciones concomitantes para elaborar un proyecto de carácter nacional, el antimilitarismo tradicional de las élites políticas, la estabilidad del sistema bipartidista y la subordinación adscriptiva de la oficialidad a estos dos partidos, son un cúmulo de factores que redujeron el protagonismo militar en el país a su mínima expresión. Solo serán las circunstancias excepcionales de La Violencia las que las harán portadoras de un papel de primer orden.

De ahí en adelante, durante el Frente Nacional y los gobiernos posteriores -hasta la actualidad- lo que va a acentuarse es su impronta anticomunista y su capacidad ofensiva en contra de las guerrillas y toda actividad sospechosa de afinidad con los ideales de izquierda -revolucionaria o no-, que se verá fortalecida no sólo por la creciente asignación presupuestal y el entrenamiento específico recibido, sino por los constantes estados de excepción ${ }^{22}$ que amplían sus facultades y les permiten llevar a cabo actuaciones con escasa regulación y casi nulas consecuencias judiciales. Con el Estatuto de Seguridad Nacional diseñado durante el gobierno de Julio César Turbay (1978-1982), las prácticas irregulares de las fuerzas militares se incrementaron considerablemente, llegando a tener características muy similares a las que se estaban presentando por la misma época en las dictaduras que afectaban el Cono Sur del continente americano, en las que la desaparición forzada de personas era una estrategia cotidiana:

En este contexto, la desaparición forzada estuvo fuertemente asociada a la lógica de la lucha contrainsurgente, y estuvo ligada a la tortura como medio para obtener confesiones del enemigo. Las desapariciones forzadas sucedieron, en ese entonces, en el marco de las detenciones sin orden judicial realizadas por la Fuerza Pública dentro de la legislación de excepción, que operó bajo la vigencia del Estatuto de Seguridad Nacional. (GMH, 2013, p. 59).

Con la derogación del Estatuto de Seguridad en el gobierno posterior, bajo la presidencia de Belisario Betancur, disminuyeron las desapariciones pero crecieron las tensiones entre las Fuerzas Militares y el gobierno, dada la voluntad política de negociación que comenzó a gestarse. Como muestra de ella, Betancur concedió una amnistía general para miembros de las guerrillas, de tal modo que se generara un ambiente de confianza para empezar a dialogar. Dicha estrategia, como vimos en el apartado precedente, tuvo cierto eco en las guerrillas, y se empezaron a gestar negociaciones que, si bien no dieron fruto durante el período de gobierno 1982-1986, abrieron la posibilidad para la firma de la paz con las guerrillas del M-19, el Quintín Lame y el EPL en 1990. Lo que se estaba buscando era volver a posicionar el poder civil en la esfera estatal y disminuir la potestad que habían ganado las Fuerzas Armadas en el manejo del orden público, lo cual tuvo como efecto la puesta en evidencia de sectores radicales que se oponían a una salida negociada del conflicto armado:

Este reajuste $[. .$.$] colisionó con sectores radicales de las Fuerzas Militares que se$ oponían a una salida política negociada del conflicto armado. Lo que siguió a esta oposición fue la intensificación de las violaciones a los Derechos Humanos por parte de agentes estatales mediante acciones clandestinas que se prolongaron hasta 1990, y que constituyeron un desafío del poder militar hacia el poder civil en el manejo del orden público. Con la promulgación de la Constitución Política de 1991 y la continuación del conflicto entre el Estado y las guerrillas de las FARC y el ELN, las desapariciones forzadas siguieron registrando altos niveles hasta 1995. Esta modalidad fue concebida

\footnotetext{
${ }^{22}$ De acuerdo con el informe ¡Basta ya! del Grupo de Memoria Histórica, “en los 21 años transcurridos entre 1970 y 1991 Colombia vivió 206 meses bajo estado de excepción, es decir 17 años, lo que cual representa el 82\% del tiempo transcurrido".
} 
como una estrategia de ocultamiento de la violencia mediante la cual los sectores más radicales de la Fuerza Pública respondieron al nuevo marco de derechos y garantías consagrado en la nueva carta política. Todo ello sin renunciar a lo que consideraban como acciones eficaces en la vieja lucha contrainsurgente (GMH, 2013, p. 60).

Esta tensión, que se mantuvo hasta el proceso de negociación de 1998-2002 durante la presidencia de Andrés Pastrana, cambió de intensidad con la postura de Álvaro Uribe, que posicionó un discurso de mano dura y volvió a establecer la estrategia militar y el sometimiento de los grupos guerrilleros como única salida posible al conflicto armado. El fortalecimiento de las Fuerzas Armadas que se había iniciado ya desde el gobierno anterior, con la firma del Plan Colombia, continuó en franco ascenso, lo que da cuenta de una búsqueda de devolverle al Estado -o quizá entregarle por primera vez- el monopolio de la fuerza, pues la falta de presencia estatal ha sido uno de los típicos argumentos esgrimidos por los grupos al margen de la ley (tanto de izquierda como de derecha) para justificar su existencia y actuaciones.

Durante el gobierno de Uribe, siendo ministro de defensa el actual presidente, Juan Manuel Santos, volvieron a estar en primera plana graves violaciones a los derechos humanos, a veces por actuaciones directas de la Fuerza Pública -como los "falsos positivos" 23-, y otras por las denuncias de actuación conjunta entre esta y grupos paramilitares. Por tal motivo, fueron destituidos altos mandos de la organización militar y algunos de ellos han sido encarcelados.

Con la llegada de Santos a la presidencia se dio paso a un nuevo intento de negociación con las FARC en medio del conflicto, lo que implica que las actuaciones tanto de las Fuerzas Militares como de la guerrilla no han cesado. Esto, quizá, ha permitido que las tensiones sean menores, pues los militares siguen llevando a cabo su misión contrainsurgente. Sin embargo, sectores civiles en cabeza del expresidente Uribe, hablan constantemente de la "desmoralización" de la tropa y hacen temer a algunos por la solidez del apoyo de las Fuerzas Armadas a las conversaciones que se están sosteniendo en La Habana, pese a la presencia de algunos militares retirados en el equipo de negociación, como es el caso del general Jorge Enrique Mora. Lo que es un hecho, por el momento, es que tal apoyo parece existir o, por lo menos, no ha habido una interferencia directa sobre ellas como ocurrió en ocasiones anteriores.

\subsubsection{El fenómeno paramilitar}

Cuando se habla de paramilitarismo, se está haciendo referencia a grupos que, por definición, tienen afinidad con las actividades militares propias del Estado, pero que no pertenecen a él. Están al lado (según lo indica el prefijo "para"), son de algún modo semejantes en cuanto a algunos de sus fines y modos de operar, pero su condición irregular les permite cruzar límites que la legalidad impone a las fuerzas armadas regulares. En Colombia, agrupaciones de esta índole han hecho parte de la vida nacional desde la época

\footnotetext{
${ }^{23}$ Se conoce con este nombre el asesinato de civiles sin ningún vínculo con el conflicto armado para hacerlos pasar como guerrilleros dados de baja en combate. Aunque se trata de una práctica que no es nueva, en el 2008 estalló un escándalo mediático al respecto por la desaparición de 11 jóvenes humildes de una localidad bogotana que, pocos días después, comenzaron a figurar como éxitos del ejército en combates con la guerrilla. Las denuncias de sus madres y la atención recibida por prestigiosos medios de comunicación (entre ellos la Revista Semana) obligaron la apertura de una investigación que evidenció lo extendida que estaba dicha práctica y, más concretamente, su exacerbación durante la administración Uribe, que entregaba beneficios económicos y permisos a los contingentes militares que presentaran mejores resultados en la lucha contrainsurgente.
} 
de La Violencia, cuando se hicieron célebres agrupaciones conocidas como pájaros y chulavitas que, muchas veces con la anuencia de algunos gobiernos y con la participación de miembros activos de la policía, se encargaban de identificar, amenazar y asesinar opositores. En este apartado nos concentraremos en los antecedentes de las organizaciones paramilitares con las que se negoció en el año 2005, haciendo especial énfasis en la constitución de las Autodefensas Unidas de Colombia, que fueron una de las expresiones más claras de la polarización del país y cuyas acciones están directamente relacionadas con la degradación del conflicto colombiano desde mediados de los años ochenta.

Según el portal de Verdad Abierta, un proyecto de investigación periodística de la Fundación Ideas para la Paz y la revista Semana, que se ha ocupado de hacer un seguimiento de las declaraciones de los paramilitares desmovilizados y de la aplicación de la Ley de Justicia y Paz en la que se enmarcó tal desmovilización:

\begin{abstract}
El fenómeno paramilitar nace como una estrategia contrainsurgente en el marco de doctrinas de seguridad nacional. Estos grupos fueron empleados como mecanismos para llevar a cabo la «lucha anticomunista» en la década de los sesenta. La creación de estructuras paramilitares, bajo el presupuesto de la eliminación del «enemigo interno», se ampara en la aplicación del decreto 3398 de 1968, convertido en el mismo año en la ley 48; este fundamento legal respalda la creación de grupos de «autodefensa» con el propósito de la formación de una «defensa nacional» y de protección civil (Verdad Abierta, recuperado en septiembre de 2013).
\end{abstract}

Estos grupos de autodefensa, promovidos y avalados por el Estado, son conocidos por los investigadores del fenómeno como paramilitarismo de primera generación, categoría que, en general, hace referencia a grupos "nacidos como reacción a la presencia de los grupos guerrilleros y con un fuerte carácter de autodefensas armadas locales - tal como ocurrió en el Magdalena Medio-" (CNRR, 2007, p. 45).

A partir de 1982, cuando se había retirado el apoyo estatal a estas agrupaciones, comienza una nueva fase, la segunda generación del paramilitarismo, de la cual puede presentarse una cronología más o menos consensuada:

1981: Creación del grupo Muerte A Secuestradores -MAS- financiado por varios narcotraficantes y terratenientes que lo usaban como medio de protección y persecución de las acciones de la guerrilla contra sus miembros. Según GMH (2013, p. 134):

Esta organización fue creada por un amplio grupo de narcotraficantes a raíz del secuestro por parte de la guerrilla del M-19 de Martha Nieves Ochoa, hermana de Jorge Luis, Juan David y Fabio Ochoa, miembros notorios del Cartel de Medellín. El MAS originario persiguió a miembros de esta y de otras guerrillas, pero cuando Martha Nieves fue puesta en libertad, se disolvió. No obstante, el nombre MAS y su derivado Masetos, siguieron siendo utilizados por otros paramilitares e incluso por miembros de la Fuerza Pública de manera genérica en varias regiones del país, para disfrazar la guerra sucia que desataron contra militantes de izquierda y líderes sociales.

1982: Se dio una reunión de agricultores y ganaderos en la ciudad de Medellín, que tuvo como resultado la creación de ACDEGAM (Asociación de comerciantes, ganaderos y agricultores del Magdalena Medio), quienes se organizaron también con el argumento de combatir el secuestro, la extorsión y otros abusos de la guerrilla. Con base en investigaciones judiciales y confesiones de jefes paramilitares, ha llegado a establecerse que una de los principales propósitos de esta asociación, legalmente constituida, era la 
canalización de recursos destinados a la financiación de grupos de autodefensa. Según Verdad Abierta, "la organización fue el brazo político y económico para el fortalecimiento del paramilitarismo en la región y su legitimación, a través de obras sociales, de infraestructura, el adoctrinamiento anticomunista de los campesinos" (Verdad Abierta, s.a.). Entre sus actividades, estuvo la contratación de mercenarios extranjeros que realizaron entrenamientos a paramilitares en distintas regiones del país. Uno de los casos más conocidos es el del exmilitar y mercenario israelí Yair Klein.

1987: Creación de las Autodefensas Unidas Campesinas de Córdoba y Urabá -ACCU-, al mando de Fidel Castaño, uno de tres hermanos (los otros dos, también paramilitares, son Vicente y Carlos), miembros de una familia antioqueña cuyo padre fue secuestrado y posteriormente asesinado por las FARC, hecho que, como el bombardeo a Marquetalia, es traído frecuentemente a colación para explicar -y justificar también- la creación de unas nuevas autodefensas campesinas, esta vez de carácter contrainsurgente. De ahí en adelante se organizaron grupos similares en diferentes regiones, bajo la denominación general de ACC -Autodefensas Campesinas de Colombia-, que representaba el estado mayor que coordinaba a las diferentes agrupaciones.

1997: Este año es crucial para la consolidación paramilitar, pues se da a conocer mediante un comunicado público la creación de las Autodefensas Unidas de Colombia, bajo el mando de Carlos Castaño (Verdad Abierta, s.a.). Dicho comunicado fue difundido a través de la cadena radial Caracol y luego replicado por medios impresos, como el periódico El Tiempo (de circulación nacional). Allí se indica que las AUC "agruparían a las Autodefensas Campesinas de Córdoba y Urabá con sus 20 frentes, a las de los Llanos Orientales y a los grupos del Magdalena Medio, con Puerto Boyacá y Las Mercedes". Igualmente, "definen el nuevo movimiento como una organización de ciudadanos armados de carácter antisubversivo que no atenta contra el Estado y tampoco depende de él" (El Tiempo, 20 de abril de 1997). Verdad Abierta identifica cuatro propósitos fundamentales de sus acciones: 1) prestar defensa a las élites rurales; 2) brindar protección a intereses políticos -de derecha-; 3) salvaguardar los intereses económicos de explotación de recursos naturales; 4) custodiar sectores vinculados a actividades agrarias, mafias y narcotráfico, a manera de ejército privado.

Durante más de una década, los grupos paramilitares se expandieron por gran parte del territorio nacional y consiguieron imponer su dominio en regiones en los que la presencia guerrillera había sido dominante por largos años, como el oriente y el Urabá antioqueño o la zona de los Montes de María en la Costa Atlántica, mediante acciones brutales y cargadas de sevicia que, como ya se trajo a colación en una cita de Pécaut, recordaban algunas de las prácticas de la época de La Violencia.

En el año 2005, la mayoría de bloques de la AUC participaron de un proceso de desmovilización bajo un modelo sui generis de justicia transicional que ha sido objeto de concienzudos análisis (Uprimny et. al, 2005) y cuyos efectos en términos de verdad y reparación están apenas comenzando a sistematizarse. El Centro de Memoria Histórica ha elaborado algunos informes sobre el proceso de Justicia y Paz, y ha hecho un esfuerzo por diferenciar la verdad judicial de la verdad histórica. En la actualidad, están llevando a cabo un programa de acuerdos por la verdad en los que se convoca a paramilitares desmovilizados para que cuenten lo que saben del origen, expansión y crímenes de los bloques a los que pertenecían, a cambio de rebajas de pena y otros beneficios jurídicos. Se espera que estos espacios, que no representan amenazas para los desmovilizados en términos de condenas judiciales, permita conocer mucha más información acerca de las operaciones de las AUC que la que han llegado a declarar en los juicios bajo la modalidad de 
"versiones libres", mecanismo contemplado en la Ley de Justicia y Paz y que deja a consideración de los acusados qué delitos confesarán. Blair et. al (2008) analizan críticamente las acciones judiciales derivadas de la aplicación de Justicia y Paz, pues se trata de “...un proceso en el que disminuyen las penas y compromisos del desmovilizado, mientras aumentan las exigencias y la presión hacia las víctimas", a las que se les exige demostrar su condición de tales aun en casos donde ni siquiera existió la posibilidad de la denuncia ante la ausencia de funcionarios que la recibieran.

Un aspecto que no deja de ser llamativo de todo el proceso de desmovilización de las AUC, es que fue presentado como un éxito contundente del gobierno en la vía de la consecución de la paz, pese a que el enemigo por excelencia delineado por ese mismo gobierno lo constituía la guerrilla de las FARC y nos la AUC. Además de esto, pasado poco tiempo de la desmovilización, empezó a documentarse la reagrupación y rearme de nuevas estructuras delincuenciales herederas de las AUC, las cuales han recibido el eufemístico nombre de "Bacrim" (bandas criminales). La Comisión Nacional de Reparación y Reconciliación dio cuenta de esto en un informe titulado Disidentes, rearmados y emergentes: ¿bandas criminales o tercera generación paramilitar?, publicado en agosto de 2007, poco más de un año después de finalizada la desmovilización. Allí, sin desconocer la importancia de la negociación exitosa que se llevó a cabo, se advierte sobre la persistencia de "diferentes modalidades de agrupaciones armadas ilegales ligadas a diversas formas de criminalidad, coerción y control político en distintas regiones del país" (CNRR, 2007, p. 5), que ponen en riesgo la participación efectiva de las víctimas de los grupos paramilitares en la aplicación de la Ley de Justicia y Paz. Entre los principales interrogantes que deja este panorama de reactivación de grupos armados, la CNRR destaca los siguientes:

Un interrogante que es urgente resolver es sobre las dudas que hay alrededor de la vinculación de los jefes de las antiguas AUC — hoy recluidos en la Cárcel de Máxima Seguridad de Itagüí- con esos grupos ilegales registrados en este informe o con actividades criminales relativas al narcotráfico, al mantenimiento de estructuras mafiosas o de intimidación y control político en las zonas en donde operaban los bloques desmovilizados. Estas dudas han generado incertidumbres frente a la desmovilización real de las AUC, tanto a nivel nacional como internacional, y han despertado la desconfianza en las víctimas que esperan verdad, justicia y reparación. Le corresponde a las autoridades competentes aclarar esas preguntas y al gobierno nacional tomar las decisiones correspondientes en relación con el retiro de los beneficios que otorga la Ley de Justicia y Paz a quienes no hayan cumplido con las condiciones para merecerlos.

Otra pregunta que surge frente a los grupos ilegales visibilizados, rearmados o reorganizados luego de la desmovilización de las AUC es si ésta es una situación transitoria característica de los procesos de desmovilización de organizaciones ilegales armadas o si estamos en el inicio de un nuevo período de violencia con características inédita (CNRR, 2007, p. 7).

Siete años después, en 2014, los resultados de investigaciones periodísticas y judiciales apuntan a que ambas sospechas eran acertadas: los jefes de las AUC mencionados en la cita y de los que se dice que estaban recluidos en una cárcel de máxima seguridad en el año 2007, fueron extraditados a los Estados Unidos en mayo de 2008, justamente con el argumento de que habían continuado coordinando actividades delictivas de sus grupos desde la prisión. Igualmente, la creciente inseguridad urbana, de la cual la ciudad de Medellín es un ejemplo dramático, indica la configuración de un nuevo "orden" armado que controla desde las rutas del narcotráfico hasta el transporte público de algunos barrios y actividades económicas de pequeños comerciantes, que se ven constantemente afectados por amenazas y extorsiones. 
Otra grave situación que comenzó a develarse poco tiempo después de iniciadas las negociaciones y que sigue siendo investigado, es el fenómeno conocido como la parapolítica, que evidenció el alto nivel de injerencia de los paramilitares en distintos niveles del gobierno nacional, desde alcaldías y consejos municipales, hasta el mismo Congreso de la República. Igualmente, se consideran parte de este mismo fenómeno las estrechas relaciones de miembros de las AUC con empresarios, terratenientes y comunicadores, a través de las cuales iban trazando la agenda de lo que podía hacerse y decirse en distintas regiones del país. Los analistas Claudia López y Óscar Sevillano inician del siguiente modo su Balance político de la parapolítica, publicado en la Revista Arcanos de la Corporación Nuevo Arco Iris ${ }^{24}$, en diciembre de 2008:

\begin{abstract}
Un día después de las elecciones de Congreso en marzo de 2002, Salvatore Mancuso expidió un comunicado de prensa en el que aseguró: "Recomendamos a la gente a quién votar." "Podemos afirmar, en tal sentido y con los datos a la mano, que la meta original del $35 \%$ ha sido largamente superada y constituye un hito en la historia de las AUC." "Tal respaldo excede, con creces, nuestras expectativas más optimistas." En el mismo sentido se pronunció el 13 de junio de 2005 el jefe paramilitar Vicente Castaño Gil en entrevista a la revista Semana: "Creo que podemos afirmar que tenemos más del 35 por ciento de amigos en el Congreso. $Y$ para las próximas elecciones vamos a aumentar ese porcentaje de amigos" (López y Sevillano, 2008, p. 63).
\end{abstract}

Pese a los continuos intentos de negociación y a que algunos de ellos han tenido un relativo éxito en materia de desmovilización, es claro que el panorama en Colombia sigue siendo incierto. Aun si el actual proceso de paz con las FARC tuviera, por fin, un desenlace positivo, está por verse la real disposición de un pueblo polarizado y lleno de odios y afán de venganza para acoger a los desmovilizados en el escenario de la contienda política legal. Además, no se trata del único actor armado que continúa desestabilizando el orden nacional, por lo que las acciones encaminadas a una normalización de la vida social y política tendrán que continuar atacando otros frentes, como las redes del narcotráfico y sus amplias conexiones con la institucionalidad.

\title{
1.3 Y ahora, ¿quién podrá defendernos? Guerras, violencia y conflicto armado en Colombia
}

Un aspecto que llama la atención al acercarse a la historia de las violencias en Colombia es la constante y continuada aparición de grupos denominados autodefensas que, como se desprende de los apartados anteriores, han sido las formas de denominación de los grupos que precedieron la aparición tanto de guerrillas como de paramilitares. Esto puede ser señal tanto de una debilidad estatal como de un largo proceso de consolidación cultural de una idea legitimadora de las prácticas violentas como vías adecuadas para dirimir cualquier tipo de conflicto. No nos referimos, por supuesto, a una suerte de "esencia" violenta de los colombianos, pero no se puede desconocer que el tipo de prácticas que se van instalando en una sociedad, así como los valores y costumbres que se promueven, configuran modos de relacionarse no sólo con los miembros del entorno más cercano, sino también con el Estado.

\footnotetext{
${ }^{24}$ Según el portal de Congreso Visible de la Universidad de los Andes, la corporación Nuevo Arcolris es "una organización no gubernamental colombiana proveniente de los Acuerdos de Paz firmados entre el Estado y la Corriente de Renovación Socialista -C.R.S-, en el año de 1994". De acuerdo con la presentación que aparece en su página web (http://arcoiris.com.co), su misión es "contribuir a la construcción de un nuevo orden social en el que prevalezcan la paz, el respeto a la diferencia, la equidad y la justicia social. Adelanta programas y proyectos de intervención en el ámbito del desarrollo humano, social, político, cultural, económico y ambiental”.
} 
En este punto, consideramos importante plantear una distinción entre tres conceptos que, aunque estrechamente relacionados entre sí merecen, a nuestro juicio, un tratamiento diferencial, a saber: guerra, violencia y conflicto (armado). De algún modo, intentaremos desarrollar y problematizar lo que expresó alguna vez William Ramírez (2003, p. 153):

\begin{abstract}
Colombia es un país donde las indefiniciones propias de la guerra civil y de la violencia parecen resolverse con autosuficientes certidumbres. Es así como se da a la primera una calificación y un tiempo preciso de desenvolvimiento (las guerras civiles del siglo XIX) y a la segunda una presentación ortográfica peculiar (La Violencia con mayúsculas para el conflicto de mediados del siglo XX) mientras a las otras, las de comienzos $\mathrm{y}$ finales del siglo XX, se le baja sin más consideraciones las mayúsculas. En tanto que el fenómeno se dio dentro de ciertos parámetros de volumen e intensidad, el empaque semántico mantuvo su tolerancia y sólo se usaron algunos retoques más de estilo que de contenido para actualizarlo (conflicto violento o conflicto armado).
\end{abstract}

\title{
1.3.1 Guerra
}

En principio, cuando se habla de guerra suele hacerse referencia a confrontaciones declaradas y organizadas, con propósitos y bandos identificables, sea esta convencional o revolucinaria (Forigua, 2006, p. 307). Para el caso colombiano, en estudios anteriores a 1998, lo común es que sólo se use este término para aludir a las guerras civiles de finales del siglo XIX y principios del XX. Sin embargo, a partir de 1998 es cada vez más frecuente que el término guerra aparezca en artículos, libros e informes gubernamentales como si comenzara a hacer carrera la idea de que las características y magnitud de lo que sucede en Colombia ameritan este calificativo. Daniel Pécaut ha sido uno de los investigadores que ha instalado el debate sobre el uso de categorías como "guerra civil» o «guerra contra la sociedad» para referirse a la situación del país. Eduardo Pizarro (2002) analiza estas y otras expresiones (guerra ambigua, guerra antiterrorista) que ha comenzado a instalarse en el argot de los estudiosos de la confrontación armada interna. Mary Kaldor hablará de nuevas guerras en el escenario mundial posterior a la guerra fría, en tanto han empezado a proliferar confrontaciones internacionales o internas en las que no es simple establecer claramente quiénes son los combatientes, cuáles son los objetivos de los enfrentamientos, con qué recursos se financian, o de qué manera los Estados les hacen frente (Kaldor, 2006).

Las razones que tornan pertinente una distinción conceptual como la que se ha dado alrededor del concepto de guerra, y que nosotros queremos ampliar a las nociones de violencia y conflicto, no son meramente académicas. La forma en que se define un fenómeno, especialmente de esta clase, tiene implicaciones políticas y militares, al tiempo que determina el curso de las acciones que tanto el Estado como organizaciones civiles pueden emprender legítimamente en relación con los actores armados y sus víctimas.

Una diferencia fundamental entre las nociones de guerra analizadas por Pizarro (guerra civil, guerra contra la sociedad, guerra ambigua y guerra antiterrorista) es si reconoce o no el estatus político de las agrupaciones alzadas en armas, cosa que, por ejemplo en el caso de las FARC, ha sido un punto constantemente problematizado. Durante la presidencia de Belisario Betancur (1982-1986), en los años ochenta, se les reconoció ese carácter, pero gobiernos posteriores hicieron lo posible por negarlo, siendo un caso paradigmático el de Álvaro Uribe Vélez. Este no solo dejó de referirse a las FARC como guerrilla, para pasar a nombrarlas como "grupo terrorista», sino que se empeñó en negar la existencia de un «conflicto armado interno», posición que le permitía tomar medidas mucho más drásticas en el juzgamiento de delitos cometidos por las FARC, así como justificar una ofensiva militar sin contemplaciones y cerrar las puertas para una salida negociada al conflicto, pues no se 
asumía a esta agrupación como un interlocutor potencialmente válido. El único escenario buscado era la derrota militar por parte del Estado.

Desde nuestro punto de vista, hablar en la actualidad de guerra en Colombia parece, al menos en principio, desproporcionado. No puede hablarse, por ejemplo, de guerra civil, puesto que no hay dos facciones en disputa, cada una con amplio apoyo popular al punto de que haya ciudadanos comunes dispuestos a tomar las armas para combatir por la imposición del grupo al que son afines. Los civiles en Colombia, como señalamos en otro momento, son más bien las víctimas recurrentes de las disputas de los actores armados, sean o no simpatizantes de uno u otro. Esto ha llevado a que estudiosos como Pécaut (2001) o Lair (2000) hablen de una guerra contra la sociedad o los civiles, respectivamente. Si bien es cierto que desde un punto de vista humanitario es dramática la situación de la población que sufre constantemente los embates de las acciones bélicas, reducir la caracterización de las mismas a una "guerra contra la sociedad» implica ignorar un elemento central de la confrontación que se presenta en el país: que se trata de una disputa entre grupos armados ilegales y el Estado (Posada Carbó, 2001; Pizarro, 2002), es decir, le resta peso a la dimensión política de la confrontación. Las mismas FARC han definido su posición en estos términos: en cartas abiertas al presidente de la República en los años 1998 y 2000, los voceros de esta guerrilla hacen referencia a los "34 años de confrontación armada entre el Estado colombiano y nuestra organización” (FARC, 1998).

Otras denominaciones que han buscado instalarse, como "guerra ambigua» o "guerra antiterrorista» tienen básicamente el mismo problema de despolitización y, en consecuencia, instalan una imposibilidad de plantear vías negociadas de resolución. En el caso de la "guerra ambigua» se resalta el papel del tráfico de drogas como motor de la economía de guerra, lo que ha servido para justificar que el apoyo económico de Estados Unidos, concretamente el que se recibe del Plan Colombia ${ }^{25}$, sea destinado tanto a la lucha antidrogas como a la lucha contrainsurgente.

Volviendo la discusión sobre el uso de la noción de guerra para referirse a la persistente confrontación armada que se ha dado entre varios actores en Colombia, es evidente la generalización de su uso (Lair, 2000; Pécaut, 2001; Sánchez, 2006; Blair, 2008; GMH, 2009, 2010, 2011, 2013). Para Blair ${ }^{26}$, se trata de un uso que está asociado al conflicto político armado que busca superar la ambigüedad que puede tener la noción más amplia de "conflicto armado», el cual, por definición, debería incluir también las disputas entre bandas urbanas que tienen motivaciones fundamentalmente económicas y en las que lo político, entendido como un proyecto o forma de concebir el orden social, no tienen mayor cabida.

Para el desarrollo del presente trabajo es imprescindible la consideración del concepto de guerra y sus usos, pues mientras las leyes que dieron origen al trabajo del Grupo de Memoria Histórica le atribuyen la responsabilidad de construir un relato sobre los grupos armados ilegales (República de Colombia, 2005) y el origen y evolución del conflicto armado (República de Colombia, 2011), varias de sus publicaciones (incluyendo el informe general entregado en 2013, emblema del cumplimiento del mandato que les fue encomendado), incluyen en sus títulos la palabra guerra como denotación de aquello de lo cual se ocupan.

\footnotetext{
${ }^{25}$ El Plan Colombia es un acuerdo bilateral entre los gobiernos de Estados Unidos y Colombia con el objetivo de generar una revitalización social y económica, crear una estrategia antinarcótica eficaz y contribuir a la finalización del conflicto armado. Fue firmado en 1999, durante las administraciones del presidente colombiano Andrés Pastrana Arango y el estadounidense Bill Clinton y se ha mantenido en el tiempo por acuerdos de los gobiernos posteriores.

${ }^{26}$ En comunicación personal.
} 
Por ejemplo, uno de sus primeros trabajos, de índole conceptual y metodológico, se titula Memorias en tiempo de guerra (2009); algunos informes de casos emblemáticos la incluyen dentro de su presentación, como La masacre de El Salado: esa guerra no era nuestra; Bojayá: la guerra sin límites; Comuna 13: la huella invisible de la guerra; y el informe general: ¡Basta ya! Memorias de guerra y dignidad.

La impresión que queda después de leer estos trabajos es que se trata de un concepto que se da por supuesto, como si el hecho mismo de la persistencia de la confrontación fuera razón suficiente y obvia para acudir al término guerra para referirse a los muchos acontecimientos que están siendo reconstruidos con base en los testimonios de víctimas y testigos. También es frecuente que se emplee como un sustituto genérico de «conflicto armado interno». Memorias en tiempo de guerra, para ilustrar solo un caso, es un libro que comienza directamente, en su primer párrafo, afirmando el hecho de la guerra: "En Colombia se vive desde 1948 y de una manera casi ininterrumpida una prolongada guerra interna, cuyo desarrollo reciente combina simultáneamente conflicto y posconflicto" (GMH, 2009, p. 14) $)^{27}$.

Esta elección, a nuestro juicio, además de dar una fuerza retórica a los títulos de los informes ${ }^{28}$, pretende resaltar las continuidades, entrecruzamientos y variaciones que se han ido entretejiendo en la confluencia de las distintas disputas que han tenido lugar en el país. Del mismo modo, es una forma de señalar el grado de filtración de estas disputas en todo el territorio nacional y en distintos niveles y capas de la sociedad, desde la institucionalidad misma hasta las iglesias, los centros educativos, las empresas locales y extranjeras; convirtiéndose en un asunto cotidiano que, si no se padece directamente, al menos se conoce y se registra constantemente a través de los medios de comunicación. Pero la razón fundamental, tal como señalaba Blair y ha sostenido hace varios años Gonzalo Sánchez, aun antes de ser director del Grupo de Memoria Histórica, es resaltar el carácter político de las luchas entre el Estado y aquellos grupos armados ilegales que de una u otra forma se han empeñado en incidir y controlar las riendas del país. Las siguientes palabras lo sintetizan bien:

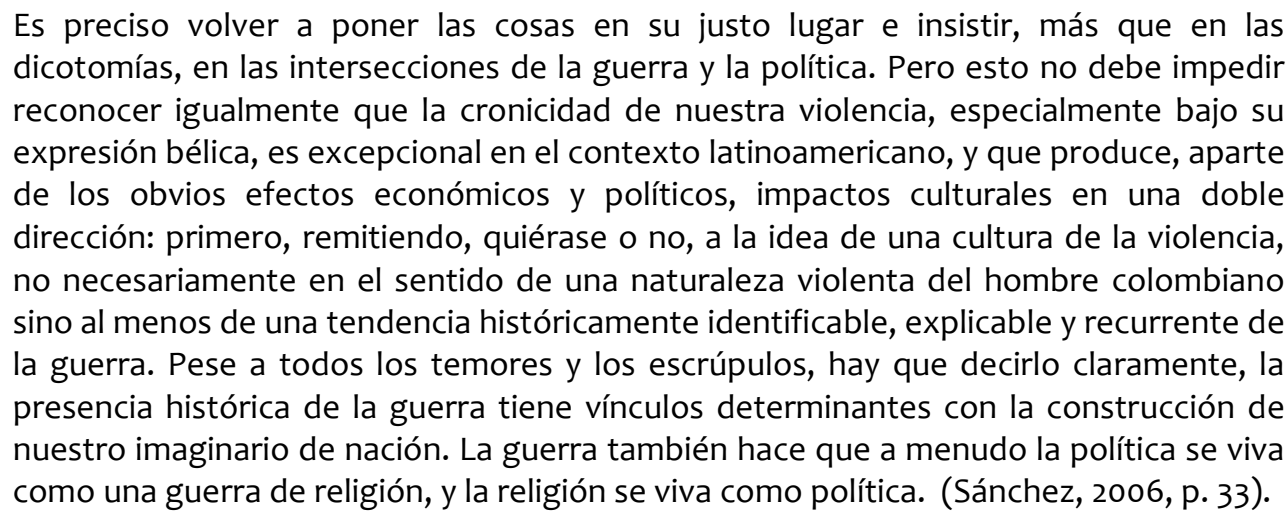

Este argumento de Sánchez que nos sirve para dejar al menos planteada -jamás resuelta- la cuestión del uso de la noción de guerra (en particular, por parte del GMH), es pertinente también para dar inicio a la discusión sobre el concepto de violencia.

\footnotetext{
${ }^{27}$ En esta frase, aparece, además, una apuesta temporal específica, que sitúa el origen de la Violencia (con mayúscula y minúscula) en 1948.

${ }^{28}$ Mauricio Builes, comunicador del GMH, comentó en entrevista realizada en enero de 2013, que una de las razones para el uso de la palabra guerra en los informes es la búsqueda de tomar cierta distancia del discurso académico y gobiernista, así como generar un impacto mayor sobre los lectores potenciales.
} 


\title{
1.3.2 Violencia
}

Como ya se ha mencionado, este término suele emplearse en Colombia con artículo (La) y mayúscula para clasificar un período impreciso de tiempo pero con una característica particular: enfrentamientos irregulares y de intensidad creciente entre liberales y conservadores, con prácticas de terror y amedrentamiento bastante descarnadas, según consta en el libro La violencia en Colombia (1962). No hay una definición propiamente dicha; se trata más bien de una clasificación desprendida de una descripción de hechos que, en su momento, fueron considerados por los estudiosos los más cruentos de la historia del país y que se enmarcaban dentro de una concepción de la violencia como uso desmedido de la fuerza para obligar la ejecución de distintas acciones o provocar temor.

Blair (2009) hace un completo recorrido por elaboraciones de autores europeos y latinoamericanos en torno al término violencia, uno de cuyos planteamientos más recurrentes es la inespecificidad del mismo por los usos tan amplios y diversos que legos y expertos han hecho del mismo, llegando a emplearlo incluso para describir fenómenos naturales particularmente devastadores. Chesnais (1981, citado por Blair, 2009, p. 12), por ejemplo, critica tanto la proliferación de sentidos que se le asignan a la violencia, como el frecuente señalamiento de que se está presentando en el mundo una ola de violencia nunca antes vista. Dice:

\begin{abstract}
Hablar de "escalada de la violencia", como se hace de manera incesante desde hace algunos años, ante la ausencia de criterio adecuado y de indicadores, es dejar el campo libre a todas las interpretaciones parciales e inimaginables. De ahí que, con frecuencia, la violencia haya llegado a designar todo choque, toda tensión, toda relación de fuerza, toda desigualdad, toda jerarquía, es decir, un poco cualquier cosa. De un año a otro su significación se amplía, su contenido se engorda e incluye los pequeños delitos intencionales, los crímenes más bajos, los intercambios de palabras, los conflictos sociales y otras contrariedades más banales. Esto es así porque los criterios de análisis son muy variados y raramente precisados. Dentro del lenguaje común, en boca de los responsables de la justicia o del orden, la noción de violencia es todavía floja, imprecisa, elástica y sobre todo extensible a voluntad.
\end{abstract}

Pese a esta laxitud semántica, o tal vez justamente por ella, intentar construir una noción más acotada del término es una labor ineludible para aquellos que estudian el conflicto armado colombiano y que se topan constantemente con el vocablo violencia. Una propuesta interesante de Blair (2009) es considerar la violencia como un fenómeno con varias dimensiones, entre las cuales las más relevantes para nuestro trabajo son la política y la cultural, ambas estrechamente enlazadas. La dimensión política de la violencia, según el rastreo hecho por esta investigadora, se relaciona directamente con el problema del Estado y es entendida por distintos autores como "el uso ilegítimo o ilegal de la fuerza", por oposición al empleo legítimo de la violencia que le correspondería al Estado. Blair, basada en planteamientos de Bourdieu, Bolívar y Nieto (2003) va más allá de esa idea y plantea la necesidad de descentrar la mirada de lo político del Estado, a fin de incluir "aspectos como las subjetividades, las emociones y los cuerpos" (Blair, 2009, p. 29). Por su parte, la dimensión cultural resulta ser la más interesante y fructífera en términos analíticos, pues tanto la política como la violencia -en su sentido de un uso de la fuerza que provoca daño y que tiene como fin el sometimiento de otros- son inherentes a la cultura. Blair adhiere a la postura del antropólogo Clifford Geertz, para quien "la cultura no es un campo ajeno a la política sino más bien que la política de un país refleja el sentido de su cultura (Blair, 2009, p. 29). En esa misma vía, si las prácticas violentas se han vuelto parte de la cotidianidad de 
una cultura, en este caso la colombiana, no es de sorprender que el ejercicio mismo de lo político incorpore la violencia, en una especie de espiral en la que es difícil distinguir qué surge primero: si lo político como desencadenante y a la vez regulador de la violencia, o la violencia como consecuencia de las disputas políticas.

Esta perspectiva resulta de algún modo afín con los planteamientos de Pécaut (1987) sobre la relación indisoluble entre orden y violencia en Colombia, según los cuales "La violencia no es el reverso del orden; ciertamente constituye una modalidad concreta de acción del Estado o de diversos grupos sociales, pero expresa también, de manera más general, la concepción de lo social que alimenta la referencia al orden". (Pécaut, 1987, p. 14). De manera más contundente, llega a afirmar:

¿Es coincidencia fortuita que la violencia adquiera tal notoriedad en un país andino donde la democracia civil restringida ha subsistido por encima de innumerables crisis? El propósito de esta obra es demostrar que no es así. La violencia es consustancial al ejercicio de una democracia que, lejos de referirse a la homogeneidad de los ciudadanos, reposa en la preservación de sus diferencias «naturales», en las adhesiones colectivas y en las redes privadas de dominio social y que, lejos de aspirar a institucionalizar las relaciones de fuerza que irrigan la sociedad, hace de ellas el resorte de su continuidad. (Pécaut, 1987, p. 17).

Sin desconocer la pertinencia de los análisis que reconocen el lugar preeminente de la violencia como signo del devenir político y social de Colombia, Gonzalo Sánchez, en el prólogo al informe general sobre el conflicto elaborado por el Grupo de Memoria Histórica, advierte sobre los riesgos de asumir sin más la presencia constante de la violencia, volviendo a hacer hincapié - como lo hizo respecto al concepto de guerra-, en la necesidad de no perder de vista el cariz político de las confrontaciones entre grupos armados ilegales y el Estado:

El carácter invasivo de la violencia y su larga duración han actuado paradójicamente en detrimento del reconocimiento de las particularidades de sus actores y sus lógicas específicas, así como de sus víctimas. Su apremiante presencia ha llevado incluso a subestimar los problemas políticos y sociales que subyacen a su origen. Por eso a menudo la solución se piensa en términos simplistas del todo o nada, que se traducen o bien en la pretensión totalitaria de exterminar al adversario, o bien en la ilusión de acabar con la violencia sin cambiar nada en la sociedad. Una lectura del conflicto en clave política mantiene las puertas abiertas para su transformación y eventual superación, lo mismo que para reconocer, reparar y dignificar a las víctimas resultantes de la confrontación armada. (GMH, 2013, p. 13).

Más allá de plantear una definición precisa de la violencia, cosa que no han conseguido hacer ni los más sesudos de sus estudiosos, nuestra pretensión es dar cuenta de la recurrencia del uso de este término que, para Blair, no debería tratar de conceptualizarse sino más bien aproximarse a él precisamente desde sus usos que, para el caso colombiano, han terminado por incluir no solamente la disputa armada sino toda una serie de manifestaciones culturales que han llevado a que se plantee la cuestión de los estragos sociales de una historia marcada por la confrontación. Respecto a la cuestión concreta del conflicto político, que es la que nos convoca, Blair es enfática en afirmar que "no es sólo la fuerza de las armas lo que caracteriza la violencia propia del conflicto político" (2009, p. 31) pues junto con ella se han expresado otra serie de violencias, como el temor, la sevicia y la crueldad, a partir de constantes intimidaciones y amenazas que terminan por propiciar un ambiente en sí mismo violento. Se trata de una violencia más profunda: 
[...] no sólo la que se queda en la dimensión física de los cuerpos sino la que afecta otros aspectos en la subjetividad de los individuos y de las sociedades: ya no sólo sus cuerpos sino sus espacios vitales, sus significaciones, el sentido de su orden" (Blair, 2009, p. 31).

El Grupo de Memoria Histórica ha hecho una reconstrucción de la memoria de los hechos violentos que, basada en la voz de las víctimas, contempla justamente estas dimensiones hondas de la violencia, tal como mostraremos con mayor detalle en el tercer capítulo de este trabajo.

\subsubsection{Conflicto armado}

Aunque no fue posible encontrar el momento preciso en que comienza a hablarse de conflicto armado, una revisión de la bibliografía sobre el asunto de la violencia en Colombia evidencia que se trata de un concepto de uso relativamente reciente. Antes de 1990, no se encontraron registros de ningún artículo o libro que se refiriera explícitamente a conflicto armado interno, aunque sí al surgimiento de las guerrillas de izquierda. Esto hace suponer que se trata de una categoría tardía que comienza a ser usada en Colombia justamente a raíz de la acción de los grupos que optan por la vía armada como forma de lucha por el poder estatal.

Sin embargo, hay que resaltar que el concepto de conflicto interno como tal tiene sus raíces en el derecho internacional y, de acuerdo con Posada Carbó (2001, p. 7), surgió como un intento de diferenciación de las guerras civiles, cuya definición se topaba con múltiples inconvenientes por la amplitud de concepciones que empezaron a forjarse en torno a ellas, y que las volvía cada vez más inespecíficas. Según Dietrich Schindler (citado por Posada Carbó, 2001), en la actualidad se distinguen cuatro tipos de conflicto: 1) los conflictos armados internacionales; 2) las guerras de liberación nacional; 3) los conflictos armados no internacionales de acuerdo con el punto 3 de la Convención de Ginebra; 4) los conflictos armados no internacionales de acuerdo con el protocolo II de 1977. Estas categorizaciones, sin embargo, resultan ambiguas y su principal utilidad es el establecimiento de normas humanitarias mínimas que deberían ser respetadas por las partes enfrentadas, sean cuales fueran los motivos de su confrontación.

Cuando se habla de conflicto «armado» se está atribuyendo una característica específica a la "contraposición de diferentes puntos de vista y de diferentes intereses», que sería una definición general y amplia de conflicto, en la que se presupone que dichas contraposiciones "pueden regularse, resolverse, e incluso transformarse, bien a través de vías pacíficas, bien a través de vías violentas (Fisas, 1998, p. 17). Teniendo en cuenta lo anterior, optaremos en nuestra investigación por adherir a la definición que de conflicto armado propone Duplat (2003) para el caso colombiano, la cual nos parece acertada en tanto aglutina los elementos en los que parece haber consenso dentro la profusa bibliografía sobre el tema. Así pues, la noción de conflicto armado será usada "para hacer referencia específica al proceso de regulación violenta del conflicto político y social que enfrenta en Colombia a guerrillas, paramilitares y ejército" (Duplat, 2003, p. 14).

En el caso puntual de los informes del GMH, es llamativo que en el desarrollo del primer capítulo del ¡Basta ya! hablan de "la violencia del conflicto armado”, mientras en el título el 
título del capítulo contiene las nociones de "guerra" y "modalidades de violencia"29. Pareciera que, desde la concepción del GMH, "guerra" y "conflicto armado" son tratados casi como sinónimos, mientras que "violencia" designa las prácticas bélicas y de coerción que caracterizan la confrontación entre los diferentes actores así como las acciones en contra de la población civil.

\subsection{Indultos y amnistías: guerra y olvido en Colombia}

Una mirada retrospectiva sobre los procesos de guerra en Colombia, sus inicios y formas de terminar, permiten percatarse de que, así como hay una innegable tradición bélica, esta ha tenido su contraparte de "consensos" y negociaciones que, según Gonzalo Sánchez (2006), en su estudio Guerras, memoria e historia ha dado pie a que culturalmente se extienda la idea de que "todo es negociable, todo el tiempo". En el mencionado estudio, Sánchez señala la tendencia a perdonar y hacer pactos como una conducta bastante generalizada desde las confrontaciones del siglo XIX:

Como parte de la recomposición política después de las guerras, en el siglo XIX, se ha señalado, hubo numerosas amnistías (perdón al delito) e indultos (perdón a la pena), no sólo a nivel nacional, sino también con radios de acción muy limitados, en el ámbito regional o local; a veces sobre el conjunto de un ejército rebelde, y otras con exclusión de los jefes; a veces por delitos específicos, y en otras con generosidad extrema, como fue la de 1880 , en la que representantes del poder constituido y de los rebeldes se conceden amnistía mutua, en una especie de versión laica del perdón en la católica Colombia del siglo XIX. (Sánchez, 2006, p. 34).

Mario Aguilera (2001) hace un recuento de las amnistías e indultos que se dieron en los siglos XIX y XX en el país, y da cuenta de 25 de las primeras y 63 de los segundos entre 1820 y 2001. Entre los aspectos más llamativos de esta tendencia, tanto para Aguilera como para Sánchez, está la indiferenciación entre delitos políticos y comunes, así como la "naturalización" de la idea de que todo momento clave en la vida política del país amerita un borrón y cuenta nueva para sacar adelante los nuevos proyectos, cosa que, evidentemente, no ha acontecido hasta ahora, pese a la aparente buena voluntad de cada una de las partes en conflicto, en distintos momentos de la historia:

[... ] en momentos claves de la vida política del país, las dos figuras [indulto y amnistía] se usan simultáneamente, tanto para delitos políticos como comunes. Esa coincidencia parece surgir en la conclusión de procesos de guerra o de violencia y como preámbulo o finalización de importantes eventos constitucionales que le han cambiado el rumbo al país. En 1820 y 1821, hubo perdón y olvido para delitos políticos y comunes, enseguida del triunfo definitivo de los ejércitos patriotas sobre los realistas; actos jurídicos que se enmarcan en los congresos fundadores de la República de Colombia y de la Gran Colombia. Luego, en la antesala de la convención de Rionegro que expidió la Constitución de 1863, y como un acto de olvido previo a esa "gran convención", se desocuparon las cárceles del país al otorgarse la amnistía y el indulto general. Al despuntar el siglo XX, en 1908, en un clima de acuerdo entre los partidos y con el deseo de olvidar las guerras y perpetuar la paz, la Asamblea Constituyente y Legislativa declaró prescrita la pena para los militares que al servicio del gobierno o de la "revolución" hubieran incurrido en delitos políticos y comunes tanto en la última guerra civil como en todas las anteriores. Posteriormente, en 1954, luego de las fases más críticas de la violencia bipartidista, y al comenzar el Frente Nacional, en 1958, se

\footnotetext{
${ }^{29}$ El primer capítulo del informe ;Basta ya! Colombia, memorias de guerra y dignidad, se titula Una guerra prolongada y degradada. Dimensiones y modalidades de violencia.
} 
expidieron sendos decretos con beneficios para los delincuentes políticos, que terminaron aplicándose indiscriminadamente a otras conductas consignadas en el código penal, dada la forma en que se definió al delito político como aquel "cuyo móvil haya sido el ataque al gobierno, o que pueda explicarse por extralimitación en el apoyo o adhesión a éste, o por aversión o sectarismos políticos" (Aguilera, 2001 -Los resaltados son nuestros).

Resaltamos las menciones al perdón y al olvido pues en el recuento presentado por Aguilera, con las referencias precisas a los textos de las leyes de amnistía e indulto, se torna evidente que en Colombia -por lo menos durante gran parte del siglo XX- ha sido escaso el interés político por la memoria, tendiendo a primar todo lo contrario. No nos referimos, por supuesto, a la memoria como categoría conceptual precisa, emparentada con la reparación a víctimas de crímenes atroces, y tampoco al campo de estudio que actualmente se enmarca bajo esta categoría, pues es bien sabido que su uso en esos sentidos más específicos es bastante reciente (Vezzetti, 2007). Sin embargo, al menos en el caso que nos ocupa, es importante observar las prácticas oficiales que propenden por el recuerdo o el olvido de hechos y momentos específicos del acontecer nacional, pues a partir de ellas es posible rastrear los énfasis, consecuencias y transformaciones que se han dado a lo largo del tiempo en Colombia y trazar un panorama sobre la memoria y el olvido en el discurso oficial sobre el conflicto armado, propósito central de la presente investigación.

Retomando el análisis sobre las amnistías e indultos en el país, se hace evidente que, sin importar cuáles fueran las posturas ideológicas de los vencedores de cada confrontación, se promovían políticas de olvido -al menos un olvido jurídico (Sánchez, 2006)- que pretendieron pasar la página, guardar silencio y hacer como si no hubiera pasado nada, con la ilusión de mantener un orden y una armonía que permitieran llevar a cabo los proyectos sociales y económicos de variado talante que estaban en la agenda de los mandatarios de turno. En especial la amnistía, que implica un olvido jurídico colectivo "era en estos casos una especie de recomienzo, en el sentido de momento inaugural del pacto social y político" (Sánchez, 2006, p. 35).

No es necesario remitirse al psicoanálisis para demostrar que estos "olvidos" impuestos, estos silenciamientos por decreto de las consecuencias penales de los delitos cometidos en medio de un conflicto, no suelen tener los efectos esperados. El malestar de las víctimas y los partidos vencidos, los ciclos de venganza que se han instalado en algunas familias, el dolor del despojo y el desarraigo continuados y el hecho de que, en la práctica, se sigue remarcando la diferencia con el otro a partir de sus acciones, sus filiaciones partidistas y su forma de pensar, no pueden borrarse por decreto y, por eso, una y otra vez han estallado enfrentamientos y guerras en el país sin que esos intentos de perdón y olvido hayan cristalizado en algo más que ideales de pacificación (Guzmán, Fals Borda y Umaña, 1962; Sánchez, 2006; Jaramillo, 2011a).

Una cosa es el olvido como proceso psíquico necesario y complementario de la memoria individual, y otra muy distinta el olvido como política, como forma de gestionar los acontecimientos traumáticos de una Nación. Si bien es cierto que Colombia no es el único país del mundo que ha hecho del olvido y el silencio una política de Estado ante sucesos infelices, sí es uno de los que la ha perpetuado por más tiempo, dejando una estela de impunidad tan larga como hondos los estragos de la fragmentación social. Guerras, memoria e historia es una indagación por esos estragos, por los problemas derivados de esa sucesión de guerras que se terminan pero no se resuelven (Coser, 1956, citado por Sánchez, 2006), que se cortan formalmente dejando pendiente algo central para una 
resolución genuina y para evitar el afloramiento constante de nuevos (pero herederos de viejos) conflictos.

¿Qué hacer con un pasado cuyas marcas siguen retumbando pese a los intentos formales por no reconocerlo? ¿Cómo enfrentan -o cómo evaden los actores sociales las cuentas no saldadas de la memoria, no saldadas con el pasado? La forma en que esto se haga determinará la transmisión de la memoria hacia el futuro. En el caso colombiano, se ha ido pasando, recientemente, de una tradición de evasión y olvido a un reconocimiento de la importancia de la memoria histórica y, aunque esto no es garantía de que hayan cesado las prácticas anteriores, introduce una variación significativa en la relación oficial con el conflicto, cuyos cortes y continuidades analizaremos más adelante.

Por ahora, para continuar explorando el paso de políticas de olvido a políticas de la memoria en el país, presentaremos un ejemplo que muestra cómo el silencio y el olvido han hecho parte esencial del tratamiento de la violencia en Colombia, en una combinación de Estado y medios de comunicación que, como ha señalado Bourdieu (1982), son actores privilegiados dentro del campo político. 


\section{ANEXO 1 Un ejemplo de la institucionalización del olvido: El pacto de silencio de 1962}

Ninguna investigación sobre el conflicto armado colombiano puede soslayar la mención del período de La Violencia y su correlato "resolutivo", el Frente Nacional. Volver al 9 de abril de 1948, día del asesinato de Jorge Eliécer Gaitán, es casi un ritual necesario, un paso obligado sin el cual no podría comprenderse la estructuración del conflicto en los siglos XX y XXI. Ese día marca un hito en la historia nacional y, por poco que se sepa del contexto en que se dio, la mayor parte de los colombianos sabe que ese fue el día del «Bogotazo», que le arrebataron la vida a un líder popular que prometía grandes transformaciones y que esa muerte desencadenó una reacción exacerbada como pocas que sumió al país en una de los períodos más sangrientos de su haber.

La convulsión, como ya se ha explicado, continuó en los años siguientes afectando a todas las regiones del país, en una cruenta batalla que se dio principalmente entre seguidores de los partidos liberal y conservador, quienes perfeccionaron sanguinarios métodos de tortura y asesinato que son la causa del nombre con el que es reconocido este período, y que es recortado por los historiadores en 1953, cuando el general Gustavo Rojas Pinilla da un golpe de estado ${ }^{30}$, con el cual sustituye el gobierno de Laureano Gómez, dando paso a un período de relativa pacificación por el apoyo que recibe de los partidos liberal y conservador, pero que se ve quebrado en 1958, cuando estos mismos partidos, ante la creciente influencia de Rojas Pinilla sobre el pueblo colombiano, firman el pacto conocido como Frente Nacional para intercalarse el poder por 16 años, en períodos de cuatro por Partido. Uno de los fundamentos de su acuerdo era "compartir las cargas del pasado, no evocarlas, obviarlas y, en últimas, dejarlas atrás” (Acevedo, 2011). Ayala Diago (1999), describe el clima de exclusión promovido por el acuerdo bipartidista:

El Frente Nacional activó la vida política del país, pero por exclusión. Al ser una negociación entre unos liberales y unos conservadores que pretendían gobernar solos, los excluidos, curtidos políticos formados a lo largo del siglo, no se dejaron arrinconar y respondieron reanimando la política nacional con elevado instinto de conservación. La oposición fue proscrita. Incluso la conciliadora (o legal) que no iba más allá de reponer rectificaciones al nuevo sistema político. Más que excluyentes, los distintos gobiernos del Frente Nacional mostraron una concepción estrecha e individual en el manejo del poder. No se trató de la conversación del bipartidismo en unipartidismo, simplemente la habilidad de los coligados por sacar los mejores frutos del pacto, extirpó las alternativas disidentes que se oponían a la imposición del modelo liberal de desarrollo.

Justamente durante este período, cuando corría el año 1962, es firmado otro pacto, esta vez de silencio, promovido por los directores de los cuatro diarios más importantes de la capital del país (El Tiempo, El Espectador, El Siglo y La República) y apoyado por los Ministros de Guerra ${ }^{31}$, Justicia y Gobierno, quienes acudieron al encuentro realizado el 4 de octubre en el salón Guillermo Valencia del Capitolio Nacional, al que habían sido convocados 34 directores de los diarios más importantes de todo el país.

Según consta en la Declaración de los directores de periódicos, publicada por El Tiempo el 7 de octubre de 1962, 33 de los 34 convocados se comprometieron a "Evitar toda polémica

\footnotetext{
${ }^{30}$ Darío Echandía, jefe del partido liberal para la época, dirá que se trata de un golpe de opinión.

${ }^{31}$ No deja de ser llamativo que el cargo que ahora se conoce como Ministerio de Defensa tuviera en esa época un nombre tan explícito y violento como Ministerio de Guerra.
} 
sobre las responsabilidades que en la violencia hayan tenido los partidos políticos, dejándole el necesario juicio histórico a una generación menos angustiada y comprometida". Asimismo, acordaron "calificar a los autores de violencia simplemente como malhechores y asesinos", a "no asignarles ningún título político a los victimarios ni a las víctimas", a "abstenerse de mencionar los nombres de los forajidos que continúan asolando campos y aldeas, a fin de que no logren el propósito de conseguir infame celebridad", y a "Reducir al mínimo la publicación de fotografías sobre episodios o hechos de violencia". De este modo, señala Acevedo (2011),

Por sugerencia de sus colegas capitalinos los directores de la prensa escrita regional estuvieron de acuerdo, pues, en callar, olvidar y desviar la mirada. El Colombiano, El Heraldo, El Universal, La Patria, Vanguardia Liberal y El País, entre muchos otros, convinieron entonces no escarbar en el pasado ni cuestionar el presente con palabras o imágenes. Estaban seguros de que esta fórmula, que hoy tildaríamos de autocensura, contribuiría a abonar mejores tiempos en los que los colombianos tendrían la calma suficiente para asignar responsabilidades concretas sobre lo sucedido. [El resaltado es nuestro]

Uno de los aspectos que resulta más sorprendente del episodio es que se trató de un pacto público, cuyos puntos no sólo fueron anunciados en los medios que lo suscribieron sino que fueron presentados como un gran logro contra la violencia, un momento que -él sí- debía ser enmarcado y recordado por su trascendencia. La imagen 1 muestra el titular con el que fue anunciado en el periódico El Tiempo: «Freno publicitario a la Violencia. Admirable jornada de los periodistas colombianos. Una declaración para enmarcar en las salas de redacción» el 7 de octubre de 1962.

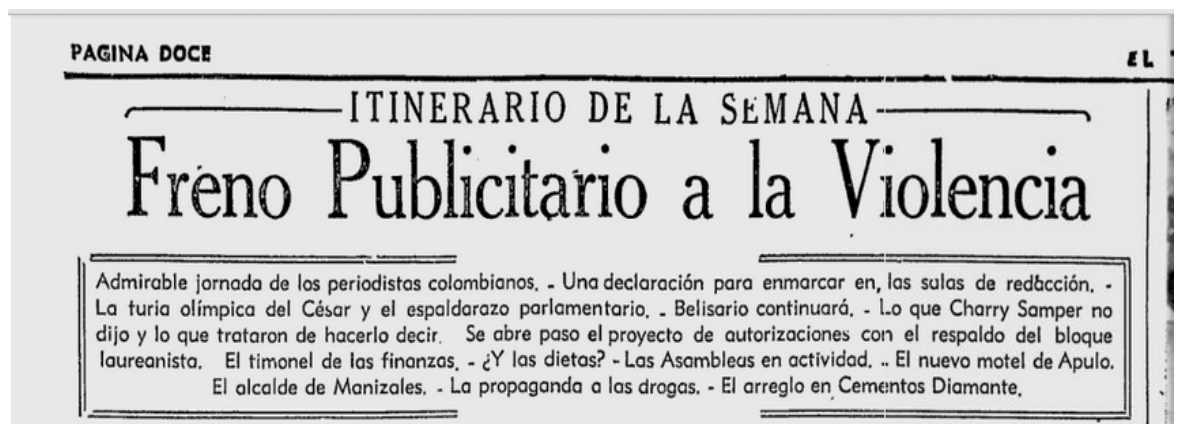

Más adelante, en la misma edición, se elogia el acuerdo, resaltando el ambiente de cordialidad en el que fue aprobado y su trascendencia: "Los directores de los periódicos, reunidos en cordial mesa redonda, acordaron, con la única excepción de quien dirige "Tribuna» ${ }^{32}$ de Ibagué, una declaración que contiene una completa norma de conducta para quienes se hicieron a la tarea difícil y peligrosa de orientar la opinión pública y darle, todos los días, el pan nuestro de las noticias” (El Tiempo, 1962).(Ver figura 2)

\footnotetext{
${ }^{32}$ Según se dejó constancia en todas la publicaciones que hicieron eco del acuerdo, el director del diario Tribuna se opuso a su firma aduciendo las siguientes razones, que fungieron como comunicado oficial del diario: "Tribuna no necesita aprobar declaración alguna para que sus lectores y el gobierno sepan que condena la violencia [...] Tribuna no cree que la violencia y el crimen y la inseguridad y el desorden se acaben [...] si la prensa deja de mencionar esos fenómenos o si los menciona con mayor despliegue [...] y sale a decir, sincronizadamente, alabanzas a la paz y a la democracia [...] Mientras fuera de los lingotes, de las columnas, de las ediciones, de los palacios de gobierno y de los clubes, la realidad es bien conocida y nada se hace por transformar la vida del hombre colombiano" (El Tiempo, 1962).
} 


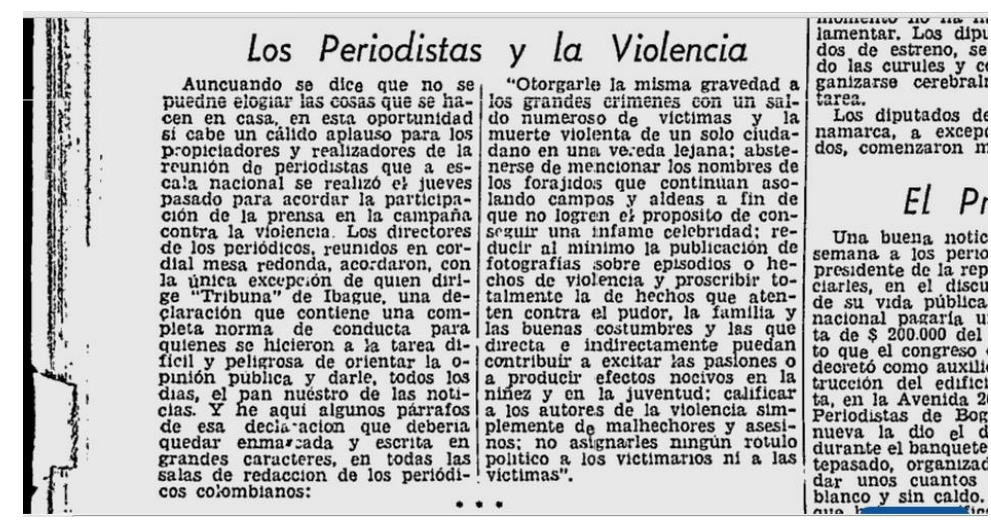

Figura 2. Tomada de Periódico El Tiempo, domingo 7 de octubre de 1962

Este episodio es relevante para nuestro estudio sobre la memoria y el olvido en el discurso oficial sobre el conflicto armado colombiano, por cuanto evidencia una clara intención de promover el silencio y el olvido desde el discurso oficial (entendido aquí en su sentido de procedente del Estado), pues si bien la propuesta surgió de los directores de diarios de circulación nacional, la sesión tuvo lugar en la casa de gobierno y a ella asistieron altos funcionarios que hacían parte a su vez del acuerdo del Frente Nacional que, como ya vimos, se había forjado con base en amnistías y "olvidos" de los hechos, así como en la exclusión de cualquier fuerza política distinta a las dos tradicionales en el manejo de los asuntos de la nación.

Además, en los países con fuertes tradiciones oligárquicas (como Colombia) o en los que se dan las condiciones para una perpetuación en cargos públicos mediante distintos artilugios democráticos, es común que los políticos de las élites sean dueños a su vez de importantes medios de comunicación (desde emisoras radiales hasta canales de televisión, pasando por periódicos y revistas de amplia circulación), lo que garantiza una amplia difusión del discurso oficial y permite controlar lo que los ciudadanos conocen del acontecer nacional y, sobre todo, las interpretaciones y sentidos que se ponen en circulación, pudiendo incidir de ese modo en la formación de "opinión pública». Sobre este tipo particular de opinión, plantea Bourdieu (1989) basándose en Mackinnon:

\begin{abstract}
Mackinnon define la opinión pública; da la definición que sería oficial si no fuera inconfesable en una sociedad democrática. Cuando se habla de opinión pública, siempre se juega un doble juego entre la definición confesable (la opinión de todos) y la opinión autorizada y eficiente que se obtiene como subconjunto restringido de la opinión pública democráticamente definida: "Es ese sentimiento sobre cualquier tema que es cultivado, producido por las personas más informadas, más inteligentes y más morales de la comunidad. Esta opinión se extiende gradualmente y es adoptada por todas las personas con alguna educación y sentimiento que conviene a un Estado civilizado". La verdad de los dominantes deviene la de todos.
\end{abstract}

Hay un ejemplo más de esta postura que podemos ubicar dentro de las políticas de olvido y silencio del Estado colombiano durante el Frente Nacional: en 1967, por orden del Ministerio de Gobierno, se declaró como "archivo muerto" el correspondiente al período 1949-1958, alegando que la oficina en la que se encontraba no estaba en condiciones de salubridad adecuadas para mantener abierto el acceso a ella. Según Sánchez (2001, p. 140), lo que se evidencia en este acto es la intención de romper la continuidad histórica dejando un vacío sobre ese lapso y haciendo de la memoria sobre él "un muerto más": 
La precisión de las fechas deja ver claramente que el problema no era el 'ambiente de olor insoportable' y el 'estado horrible' de la oficina, como se arguyó, sino la pestilencia de la época que había que suprimir. El despojo de la memoria colectiva y por lo tanto de la identidad durante La Violencia hizo muy arduo, demasiado arduo, el proceso de reconstrucción de los espacios para la creación y la crítica.

Hemos expuesto hasta aquí algunos ejemplos que dan soporte a la idea generalizada de que Colombia es un país sin memoria, pero continuáremos nuestra exploración en el siguiente capítulo mostrando también las facetas de intentos de comprensión y, más recientemente, de construcción de la memoria, que también han surgido en el seno mismo del Estado. De este modo, se problematizarán distintas posturas que han surgido dentro de la estructura estatal no sólo en diferentes períodos históricos, sino también en un mismo gobierno, una de cuyas expresiones más patentes es la conformación, en el año 2007, del Grupo de Memoria Histórica. Las funciones y productos de este organismo estatal han estado en tensión con el discurso oficial desde sus inicios, durante la presidencia de Álvaro Uribe Vélez, y responden en la actualidad, bajo otro manto presidencial, a un mandato que resulta, cuanto menos, paradójico: reconstruir la memoria histórica del conflicto armado en Colombia sin forjar una verdad oficial. Al menos así lo plantea expresamente la Ley 1448 de 2011 -conocida como Ley de Víctimas y Restitución de Tierras- en un parágrafo a su artículo 143 (sobre el «deber de memoria del estado»), que reza explícitamente:

En ningún caso las instituciones del Estado podrán impulsar o promover ejercicios orientados a la construcción de una historia o verdad oficial que niegue, vulnere o restrinja los principios constitucionales de pluralidad, participación y solidaridad y los derechos de libertad de expresión y pensamiento. Se respetará también la prohibición de censura consagrada en la Carta Política (Ley 1448 de 2011). 


\title{
CAPÍTULO 2
}

\section{DEL SILENCIO A LA EVOCACIÓN \\ Conformación, acciones y transformaciones del Grupo de Memoria Histórica}

\begin{abstract}
Antes de saber lo que la historia dice de una sociedad, nos importa analizar cómo funciona ella misma. Esta institución se inscribe en un complejo que le permite solamente un tipo de producciones y le prohíbe otras. Así procede la doble función del lugar. Vuelve posibles algunas investigaciones, gracias a coyunturas $y$ problemáticas comunes. Pero a otras las vuelve imposibles; excluye del discurso lo que constituye su condición en un momento dado, desempeña el papel de una censura en lo referente a los postulados presentes (sociales, económicos, políticos) del análisis. Sin duda alguna esta combinación de permiso con la prohibición es el punto ciego de la investigación histórica y la razón por la cual no es compatible con cualquier cosa. Y precisamente sobre esta combinación debe actuar el trabajo destinado a modificarla.
\end{abstract}

Michel de Certeau, La escritura de la historia

\subsection{Entender y recordar: de las comisiones de estudio al Grupo de Memoria Histórica}

La pregunta por el origen y perpetuación de la violencia en Colombia ha sido recurrente en la academia local e internacional. El «caso colombiano» ha revestido particular interés por las paradojas que encierra su historia, en la que democracia, inestabilidad política y conflicto han estado siempre asociados. La guerrilla de las Fuerzas Armadas Revolucionarias de Colombia -FARC- es una de las más antiguas del mundo y existen otros grupos armados, de izquierda y de derecha, que siguen alimentando una guerra con más aristas cada vez.

Dado que el foco de nuestra investigación es el discurso oficial ${ }^{33}$ sobre el conflicto armado, dirigiremos nuestra mirada hacia los esfuerzos que desde el Estado se han hecho para comprender y abordar dicho conflicto. Siguiendo a Sánchez (1993) y Jaramillo (2011), podemos identificar cuatro grandes experiencias que han ido en esta vía: La Comisión nacional investigadora de las causas y situaciones presentes de la violencia en el territorio nacional, de 1958; la Comisión de expertos (más conocida en el ámbito académico como la comisión de "violentólogos"), en 1987; la Comisión de superación de la violencia, en 1992; y el sub-área de memoria histórica de la Comisión Nacional de Reparación y Reconciliación, que inició formalmente sus labores en el año 2007 y que, a partir del 2012, opera autónomamente como Centro de Memoria Histórica. Los orígenes de cada una de estas

\footnotetext{
33 Para efectos de nuestro proyecto, tendremos en cuenta la relación entre lo oficial y lo estatal, así como la incidencia de sus posiciones discursivas en la formación de la opinión pública, pero tomaremos en cuenta también la recomendación de Soprano de “...comprender las historicidades específicas de los proyectos institucionales de las agencias estatales (en plural), evitando considerar al Estado (en singular) únicamente como una categoría sociológica con pretensiones de totalidad social homogénea" (Soprano, 2007:19).
} 
comisiones se relacionan con hitos en la historia del país: 1) el "fin" de la Violencia y el inicio del Frente Nacional, 2) el recrudecimiento de la violencia urbana y el desprestigio internacional de la nación por cuenta del narcotráfico, 3) la firma de acuerdos de paz con el M-19, el Ejército Popular de Liberación -EPL-y el Movimiento indígena Quintín Lame; y 4) el proceso de negociación con las Autodefensas Unidas de Colombia, uno de los grupos paramilitares más fuertes y sanguinarios en el pasado reciente.

Las motivaciones de estos grupos y comisiones han sido evidentemente políticas, no sólo por su origen estatal, sino por las coyunturas en las que se decide conformarlas; expresión tanto de una preocupación ante la exacerbación de fenómenos que han terminado por ser parte casi "natural" del panorama nacional, como de la necesidad de establecer condiciones que hagan posible la sostenibilidad de procesos de negociación con actores armados. Nuestro análisis, como ya se ha ido perfilando, está focalizado en la última de las iniciativas estatales, pero consideramos importante hacer primero una aproximación a las anteriores con el fin de ir vislumbrando las transformaciones de la posición estatal -por influencia de distintos gobiernos y por coyunturas políticas puntuales- en el tratamiento, comprensión e interpretaciones de la violencia y el conflicto armado.

\subsubsection{Comisión nacional investigadora de las causas y situaciones presentes de la violencia en el territorio nacional (1958)}

Esta Comisión fue creada por una junta militar que, en 1957, estuvo en el poder durante la transición entre el gobierno del general Rojas Pinilla y el primero de los gobiernos del Frente Nacional. La integraron en total siete personalidades pertenecientes a los partidos liberal y conservador, a la iglesia y al ejército, con la misión de

[...] radiografiar los impactos de la Violencia en las principales regiones del país y producir informes permanentes al presidente Alberto Lleras Camargo [... ]. El objetivo de esta comisión estuvo básicamente encaminado a facilitar la pacificación y la rehabilitación de las zonas afectadas por la violencia, aunque también creó las condiciones para la diseminación de responsabilidades por lo ocurrido en toda la sociedad y no en los directos responsables del desangre" (Jaramillo, 2011, p. 14).

El contexto de transición y pacto político en el que se enmarcó -el Frente Nacional-, hizo que el trabajo de esta comisión estuviera bastante limitado, sobre todo en lo que a su función investigadora y explicativa se refiere. Creada inicialmente para ejercer funciones durante 60 días, terminó actuando por un plazo de nueve meses (mayo de 1959 a enero de 1960), lapso en el cual los investigadores, después de hacer un acopio documental desde la capital del país, se trasladaron a las regiones más convulsionadas desde 1948, hicieron un diagnóstico de las situaciones regionales, escucharon por primera vez a campesinos y "damnificados de la violencia" -para la época no se usaba la noción de víctima- (Sánchez y Reátegui, 2012; Jaramillo, 2011a) y promovieron pequeños pactos de paz en las poblaciones visitadas, siendo particularmente significativo el número de estos en el departamento del Tolima. Su labor no quedó reflejada en ningún texto escrito de carácter oficial, aunque los comisionados entregaban informes verbales al presidente de la época -Alberto Lleras Camargo- y los pormenores de su trabajo eran permanentemente registrados por la prensa escrita (Jaramillo, 2011a), que se encargó de difundir los relatos y narrativas "que estructuraron la forma como se procesaría y representaría política y socialmente la Violencia" (Jaramillo, 2011a).

En la tesis de Doctorado titulada Las comisiones de estudio sobre la violencia en Colombia: tramas narrativas y ofertas de sentido temporal para comprender la violencia, Jefferson 
Jaramillo (2011) hace una revisión exhaustiva del trabajo de esta comisión y plantea que sus alcances investigativos quedaron relegados por dos razones fundamentales: la prohibición tácita de hacer señalamientos directos a los partidos Liberal y Conservador como actores claves del surgimiento de la violencia y el interés pacificador -casi pastoral, dirá Jaramilloque primaba en los comisionados, los cuales, a tono con los propósitos del Frente Nacional, estaban más concentrados en realizar un diagnóstico del presente que permitiera hacer los ajustes necesarios para planear un futuro sin conflicto, cosa que, evidentemente, no se logró:

\begin{abstract}
La labor de La [comisión] Investigadora no fue sólo descriptiva del presente o de revelación controlada de la magnitud de una problemática. También tuvo una finalidad terapéutica y pastoral. De hecho, se correspondía con la visión que el Frente Nacional se encargaba de vender al gran público en su objetivo de superar el desangre: una gran operación de paz y salvación nacional. Si bien esta era una estrategia diseñada por élites políticas pragmáticas, su lectura del país de entonces irradiaba un aroma casi evangelizador que buscaba atender a los damnificados pero también pastorearlos, reincorporar a los excombatientes a la vida ciudadana, pero también redimirlos de sus culpas históricas, generar amnistías pero también administrar institucionalmente el perdón político.
\end{abstract}

La forma en que operó y el tratamiento que hizo del pasado, ha hecho que los estudiosos del conflicto (Pécaut, 2010, citado por Jaramillo, 2011) ubiquen esta Comisión en lo que al final del primer capítulo caracterizamos como «políticas de olvido» y de silencio, por su exclusión de las voces de las víctimas y la sociedad civil y por su intento de diluir responsabilidades, llegando al punto que Arendt (1964) critica con ahínco de que allí donde todos son culpables, nadie lo es.

Pese a las limitaciones señaladas y a que no se produjo ningún informe oficial, los insumos recogidos durante los meses de trabajo fueron retomados pocos años después por uno de los integrantes de la Comisión, Monseñor Germán Guzmán, en asocio con Orlando Fals Borda -decano de la naciente carrera de sociología en la Universidad Nacional- y Eduardo Umaña Luna, dando origen al primer estudio académico sobre el conflicto del país, La violencia en Colombia (Guzmán, Fals Borda y Umañana, 1962). Gonzalo Sánchez (1999) resalta de esta publicación el hecho de que se trata del primer producto colectivo de las ciencias sociales en Colombia, así como su capital importancia más allá de la esfera intelectual:

[...] en este libro no sólo es notable su gestión, sino las múltiples funciones que cumplió en su momento y las que lo han hecho perdurable: Libro denuncia, más que un libro de intención académica, La violencia en Colombia es un texto de decidida intención política, no en el sentido partidista, como tendió a utilizarse inicialmente, sino de enjuiciamiento histórico a las élites gobernantes responsables del desangre. Es esta dimensión la que entre otras cosas explica las reacciones de la prensa, de los poderes civiles, eclesiásticos y militares y la que lo convirtió en objeto de debate incluso en el Senado. En perspectiva histórica se puede aseverar que uno de los grandes méritos del libro es haber hecho de la Violencia un tema de opinión y de controversia pública. Muchos sectores citadinos descubrieron aterrorizados la Violencia a través de este libro.

Aunque en los meses inmediatos a su publicación fue duramente criticado por la élite política, según relata Fals Borda en el prólogo a le edición del 2005, su repercusión en los estudiosos del conflicto armado es palpable por las constantes referencias que a él se hacen y porque, de alguna manera, las luchas partidistas de las que da cuenta han continuado marcando la confrontación armada en el país, sumadas, por supuesto, a otras 
problemáticas; pero también porque constituye una radiografía de prácticas de violencia excesiva que han resurgido con el accionar de los grupos paramilitares.

\subsubsection{Comisión de estudios sobre la violencia (1987)}

Casi treinta años después de la primera Comisión Investigadora, durante el gobierno del presidente Virgilio Barco, y tras varios intentos fallidos de negociación con las guerrillas de las FARC y el M-19, se creó esta Comisión de estudios sobre la violencia. En los medios sociales y académicos es recordada como la comisión de «violentólogos» (Bejarano, 1995; Galindo y Valencia, 1999), mientas ellos mismos se autodenominaban «intelectuales para la democracia» (Jaramillo, 2011). Esta autodescripción deja clara su procedencia académica ilustrada, esta vez sin presencia directa de personalidades políticas, eclesiásticas o militares en ejercicio ${ }^{34}$, pero tampoco de víctimas de la violencia o personas de la sociedad civil, lo que le ha valido una serie de críticas a su informe, titulado Colombia: violencia y democracia (Sánchez, 1987). Dos fueron sus objetivos esenciales: 1) realizar un diagnóstico de la situación de la violencia en esa época y 2), generar recomendaciones útiles para el gobierno. Fue presidida por Gonzalo Sánchez -compilador, junto con Ricardo Peñaranda, del libro Pasado y presente de la violencia en Colombia (1986)-, quien estuvo al frente del Grupo de Memoria Histórica entre 2007 y 2010 y actualmente (2012) dirige el trabajo del Centro de Memoria Histórica.

Como respuesta al primero de sus objetivos, Jaramillo (2011) plantea que se dio la "construcción de unas tipologías académicas de violencias múltiples que describían lo que pasaba en los años ochenta, especialmente con el sicariato y las violencias de la calle", mientras sobre el segundo, "planteó una serie de recomendaciones encaminadas a la generación de programas de seguridad urbana y la construcción de escenarios y mecanismos de paz negociada con los actores armados"

El informe de esta comisión se convirtió rápidamente en un referente para entender las causas y tipos de violencia en Colombia, pero también suscitó grandes polémicas y críticas, que el propio Gonzalo Sánchez (2000, p. 280) clasifica en tres grandes ejes: la visión fragmentaria del fenómeno, la minimización de las dimensiones políticas al optar por la referencia a un sistema de violencias y el sobredimensionamiento de las «causas objetivas» (como la pobreza y la desigualdad) que, para algunos críticos, ha servido como justificación de la lucha armada.

Será interesante constatar, en el análisis de los informes del Grupo de Memoria Histórica, no sólo el cambio de enfoque para aproximarse a la comprensión del conflicto (que sitúa en el centro la voz de las víctimas) sino también una visión más holística del fenómeno que, en lugar, de presentar una división por tipos de violencia, apelará a una noción de guerra que, a nuestro entender, pretende abarcar la complejidad del fenómeno de la violencia y el conflicto y los intrincados entrecruzamientos de problemáticas que han sumido a la sociedad colombiana en un estado de confrontación permanente, que adopta, por épocas, distintas modalidades.

\footnotetext{
${ }^{34}$ Por sugerencia del grupo y del gobierno de la época, se incluyó en la comisión al general retirado Luis Alberto Andrade Anaya, quien había realizado estudios sobre los conflictos sociales. (Al respecto, véase el artículo titulado Nadie se salva de la Revista Semana. Recuperado en: http://www.semana.com/wf_ImprimirArticulo.aspx?IdArt=23392)
} 


\subsubsection{Comisión para la superación de la violencia (1992)}

Cuatro años después de publicado el trabajo de la comisión anterior, las Consejerías de Paz y Derechos humanos de la Presidencia de la República conformaron la Comisión para la superación de la violencia como parte de los acuerdos de paz que permitieron la desmovilización de tres grupos armados ilegales: El Movimiento 19 de Abril -M-19-, el Ejército Popular de Liberación y el Movimiento Indígena Quintín Lame. Estaba integrada por académicos de reconocida trayectoria en el estudio del conflicto armado, así como en el campo de los derechos humanos (Villarraga, 2009). Su propósito fue el estudio de las particularidades de la violencia en siete regiones del país donde operaban estas dos agrupaciones, con el fin de establecer una serie de recomendaciones para la sostenibilidad de la paz que estuvieran acordes con los matices específicos que la guerra había tomado en cada región, además de presentar un panorama de las reconfiguraciones que otros actores armados (que no participaron de la negociación) estaban instalando en los territorios que dejaron de estar bajo el control del M-19, el EPL y el Quintín Lame (Reyes \& Correa, 1992, p. 7).

Los hallazgos y recomendaciones resultantes de su labor de siete meses de investigación fueron presentados en una publicación titulada Pacificar la paz, cuyo principal aporte y contraste con el informe de la comisión de 1987 fue, según Sánchez (1993), la elaboración de una tipología de las regiones que complementaba la tipología de la violencia que había sido trazada en Colombia: violencia y democracia. Además, su énfasis estaba puesto en el escenario posterior a la negociación y los retos que esta implicaba para la sociedad y el Estado, mientras que el informe de 1987 fue escrito cuando todavía ninguno de los grupos armados que hacían parte del conflicto había firmado un acuerdo de paz. Otra característica importante de este informe es la consideración de las características particulares de las comunidades indígenas, haciendo énfasis en el tratamiento diferencial que ameritan (Villarraga, 2009).

Entre las recomendaciones contenidas en Pacificar la paz se destacan la imperiosa necesidad de una reforma agraria en algunas zonas; el pacto social con los desmovilizados, en otras; y la consideración de la influencia del narcotráfico en casi todas. Asimismo, su apuesta más fuerte estuvo orientada a reconocer la validez y posible eficacia de los diálogos regionales, "entendidos no necesariamente como interlocución entre autoridades locales y la guerrilla, sino como foros comunitarios sobre la violencia, incluida la violencia guerrillera sobre las comunidades" (Sánchez, 1993).

Según señala Álvaro Villarraga (2009), miembro del Comité Ejecutivo de la Red nacional de iniciativas para la paz y contra la guerra -REDEPAZ- y presidente de la Fundación Cultura Democrática:

\footnotetext{
Los resultados de la Comisión de Superación de la Violencia fueron entregados al Gobierno Nacional, a los voceros nacionales del EPL y del Quintín Lame y publicados. Sin embargo, nunca hubo una respuesta oficial y las recomendaciones como tal no fueron adoptadas por el Gobierno nacional. Dentro de sus conclusiones la Comisión de Superación de la Violencia propuso crear una comisión de esclarecimiento con relación a la problemática de derechos humanos y derecho humanitario, en el contexto del proceso de paz, lo cual pudo ser retomado por experiencias posteriores.
}

Al igual que sucedió con los insumos de las comisiones anteriores, el informe Pacificar la paz se encontró con limitaciones tanto de recepción como de aplicación pues, como sus autores mismos previeron, mientras no se negociara con todos los actores del conflicto y 
no se prestara suficiente atención al creciente problema del narcotráfico, los importantes acuerdos de paz que se habían firmado no alcanzarían para superar la prolongada racha de violencia en el país (Comisión para la superación de la violencia, 1992).

Las tres comisiones que hemos presentado dan cuenta de un intento oficial por comprender el fenómeno de la violencia y el conflicto armado, así como sus formas de manifestación en el país, pero en ellas la construcción de la memoria y el reconocimiento de responsabilidades no fue un aspecto fundamental, lo cual contrasta fuertemente con la labor que ha venido haciendo el Grupo de Memoria Histórica, del cual nos ocuparemos a continuación. La diferencia que marca su trabajo en el tratamiento del asunto no está dada únicamente porque se circunscribe al estudio del conflicto armado sino porque tiene como misión "elaborar una narrativa integradora e incluyente sobre las razones para el surgimiento y la evolución del conflicto armado interno, sobre los actores e intereses en pugna, así como sobre las memorias que se han gestado en medio del mismo, con opción preferencial por las memorias de las víctimas y por las que han sido hasta ahora suprimidas, subordinadas o silenciadas" (GMH, 2009).

En lo que sigue analizaremos su conformación, trayectoria, productos y, en especial, las paradojas que supone la reconstrucción de las memorias desde un organismo oficial pero con la pretensión de que no se genere una verdad que tenga el mismo carácter. Esta es una veta interesante para el abordaje que estamos realizando sobre memoria y olvido en el discurso oficial sobre el conflicto armado colombiano, puesto que permite analizar con otros ojos la clásica sospecha que se cierne sobre las memorias nacionales y cualquier iniciativa que provenga de la estatalidad.

\subsection{Un Estado, dos formas de asumir el deber de memoria}

Según han señalado diferentes estudiosos (Traverso, 2007; Salvi, 2009, 2011; Hartog, 2012; Vecchioli, 2013) nos encontramos en el momento de las víctimas. Su voz, que ha existido siempre (en el sentido de que hay una tendencia general de los seres humanos a contar y narrar sus experiencias, en tanto seres sociales y simbólicos) $)^{35}$ pero no ha sido siempre escuchada por el gran público o las sociedades, ha empezado a ocupar cada vez más un lugar preeminente en los debates públicos y se ha ido instalando el imperativo de su reconocimiento como testigos de un pasado que es deber de las sociedades recordar. Este deber de memoria como mandato tiene sus riesgos y puede prestarse a diferentes abusos en función de sus usos políticos y públicos (Todorov, 2000; Traverso, 2007), aunque también, como sostiene Reyes Mate (2011), es una vía para la ampliación del conocimiento acerca de lo sucedido y una forma de luchar contra la tradición amnésica de las culturas dominantes. Uno de los objetivos de este trabajo será justamente rastrear cómo ha sido puesto en juego el deber de memoria del Estado que fue establecido por las leyes que crearon y regulan el trabajo del Grupo de Memoria Histórica, a saber, la Ley 975 de $2005^{36}$ (Ley de justicia y paz) y la Ley 1448 de $2011^{37}$ (Ley de víctimas y restitución de tierras), cada

\footnotetext{
${ }^{35}$ Esta idea fue expresada por Alessandro Portelli en su seminario Historia e historia oral, dictado en la Universidad Nacional de La Plata entre el 9 y el 13 de septiembre de 2013. Reyes Mate sostiene algo similar cuando dice: "Las víctimas han existido siempre, pero eran insignificantes. Y lo que hace la memoria es hacerlas significativas”. (Entrevista a Reyes Mate realizada por Berta Ares en 2011, publicada en la revista electrónica Revista de Letras. Disponible en: http://revistadeletras.net/reyes-mate-existe-un-deber-de-memoria-porque-alconocimiento-se-le-escapa-mucha-realidad/)

${ }^{36}$ Ley 975 de 2005. Disponible en: http://web.presidencia.gov.co/leyes/2005/julio/ley975250705.pdf (Consulta realizada 3 de diciembre de 2013)

37 Ley 1448 de 2011. Disponible en:
} 
una de las cuales estableció lineamientos para que el Estado cumpliera con su deber de memoria. La comparación de las dos leyes pone en evidencia cambios sustanciales asociados al cambio de gobierno, los cuales tienen que ver con el tipo de actores que van a ocupar un lugar central así como del tipo de relato que habría de ser construido por el ente que asumiera las funciones de reconstrucción de la memoria.

La primera ley, del año 2005, y a la que nos referiremos de aquí en adelante como Ley de justicia y paz, proveyó el marco legal en el que se insertó el único proceso masivo de desmovilización paramilitar que se ha dado en la historia de la confrontación armada colombiana, y sentó las bases para una preservación de la memoria de acontecimientos violentos, apoyada directamente por el Estado. Su objetivo era reglamentar las condiciones para "la reincorporación de miembros de grupos armados organizados al margen de la ley, que contribuyan de manera efectiva a la consecución de la paz nacional" y establecer disposiciones para acuerdos humanitarios. Por estar concentrada fundamentalmente en la desmovilización de actores armados ilegales y su posterior reinserción a la vida civil, el acento de la mayoría de las directrices allí expuestas se relacionaban directamente con este sector de la población, mientras las víctimas de sus acciones eran tenidas en cuenta para efectos de reparación económica y simbólica, mas no eran consideradas como agentes esenciales para la reconstrucción de la memoria histórica.

Una de las críticas recurrentes a la Ley de justicia y paz fue la omisión en su texto definitivo de la noción de conflicto armado, omisión que estuvo a tono con la posición del entonces presidente -Álvaro Uribe Vélez-, quien en reiteradas ocasiones y en distintos encuentros internacionales declaró que en el país no había conflicto armado sino "amenaza terrorista" ${ }^{38}$. En consonancia con esta postura, a lo largo de la ley se habla una y otra vez de "grupos armados organizados al margen de la ley" y es en relación con ellos que se definen tanto las víctimas como el deber de memoria del Estado. Así, para que una persona fuera considerada víctima, debía demostrar que los daños sufridos en términos de lesiones físicas y psicológicas (transitorias o permanentes), sufrimiento emocional, pérdidas económicas o menoscabo de los derechos fundamentales, eran "consecuencia de acciones que hayan transgredido la legislación penal, realizadas por grupos armados organizados al margen de la ley" ${ }^{39}$. Del mismo modo, el artículo 56, que define específicamente el deber de memoria del Estado (uno de los componentes de la reparación ${ }^{40}$ a la que tienen derecho las víctimas), dice textualmente: "El conocimiento de la historia de las causas, desarrollos y consecuencias de la acción de los grupos armados al margen de la ley deberá ser mantenido mediante procedimientos adecuados, en cumplimiento del deber a la preservación de la memoria histórica que corresponde al Estado" (República de Colombia, 2005).

¿Cuál es la importancia de esta aparente sutileza en el lenguaje y por qué es relevante dentro de la presente investigación? La noción de conflicto armado hace alusión a un

http://wsp.presidencia.gov.co/Normativa/Leyes/Documents/ley144810062011.pdf (Consulta realizada el 3 de julio de 2011)

${ }^{38}$ Para una cronología y un análisis crítico de tal afirmación, véase el artículo "Sí hay guerra, señor presidente", de la Revista Semana. [En línea] Disponible en: http://www.semana.com/portada/guerra-senorpresidente/84650-3.aspx

${ }^{39}$ Artículo 5, Ley 975 de 2005.

${ }^{40}$ Según el artículo 8, "El derecho de las víctimas a la reparación comprende las acciones que propendan por la restitución, indemnización, rehabilitación, satisfacción; y las garantías de no repetición de las conductas". Asimismo se contempla una reparación simbólica que se refiere a "toda prestación realizada a favor de las víctimas o de la comunidad en general que tienda a asegurar la preservación de la memoria histórica, la no repetición de los hechos victimizantes, la aceptación pública de los hechos, el perdón público y el restablecimiento de la dignidad de las víctimas". 
enfrentamiento entre grupos armados ilegales y el Estado, lo que implica que este último es uno de los actores involucrados en la confrontación, y no un mero receptor de los ataques perpetrados por agrupaciones ilegales. De hecho, en el caso colombiano, se ha probado la participación de miembros de las fuerzas armadas regulares en acciones conjuntas con grupos ilegales y sobre el Estado pesan sentencias de la Corte Interamericana de Derechos Humanos ${ }^{41}$ que dan cuenta de que este no ha cumplido siempre ni en todas las regiones con su función de protección y defensa de los ciudadanos. El panorama es entonces más complejo de lo que se desprende de una versión de los hechos que, como la planteada por la Ley de justicia y paz, mantiene al Estado al margen de las responsabilidades por los efectos de una confrontación bélica que se ha mantenido por décadas. Que el Estado se reconozca o excluya como actor del conflicto tiene consecuencias políticas y simbólicas de no poca envergadura, no sólo en términos de lo que sería una memoria nacional basada en su exclusión (tal como la que se desprendería del mandato inicial de Justicia y paz), sino también en relación a quiénes son consideradas víctimas y, en esa medida, tienen derecho a las reparaciones y restablecimiento de derechos ordenadas por la ley: si sólo se consideran las personas que han sufrido daños por las acciones de grupos ilegales, no queda lugar para las víctimas de acciones del Estado ni para aquellas que han sufrido los efectos directos o colaterales de la confrontación entre este y los grupos al margen de la ley.

Ateniéndonos estrictamente al tipo de relato que podría construirse a la luz de las directrices de la Ley de justicia y paz, nos encontramos ante una perspectiva sesgada que deja deliberadamente por fuera la posibilidad de contemplar la relación que ha existido entre funcionarios e instituciones gubernamentales con grupos al margen de la ley, desconociendo una historia de disputas por el poder entre diferentes partidos y movimientos que han sido libradas mediante alianzas no siempre declaradas abiertamente y no siempre del lado de la legalidad. Estas alianzas entre poderes y el uso de estrategias violentas e ilegales por parte de partidos y gobiernos de turno se remontan hasta mediados del siglo XIX y han sido documentadas de forma tan contundente (Guzmán et. al., 1962; Sánchez, 2006; Pécaut, 1987; Bushnell, 1994) que no deja de ser llamativa la pretensión de ignorarlas. Se llegó así a la formulación de una ley que presentaba un panorama simple y dicotómico de las cosas: existe el Estado, por un lado, y los grupos armados organizados al margen de la ley, por el otro. El primero cumple a cabalidad sus funciones y no tiene por qué ser cuestionado o demandado, no ha dejado víctimas en el ejercicio de su poder y se presenta como garante para la reparación de las únicas víctimas que existen: las de los grupos ilegales. En este orden de ideas, la Comisión Nacional de Reparación y Reconciliación -CNRR-, órgano creado con el fin de "facilitar los procesos de paz y la reincorporación individual o colectiva a la vida civil de miembros de grupos armados al margen de la ley, garantizando los derechos de las víctimas a la verdad, la justicia y la reparación" ${ }^{42}$ (según la descripción que de ella aparece en la página web de la Vicepresidencia de la República) tenía, entre sus múltiples funciones, la de "presentar un informe público sobre las razones para el surgimiento y evolución de los grupos armados ilegales" (República de Colombia, 2005, artículo 51), quedándose por fuera las otras dimensiones que acabaron de mencionarse.

En este contexto y bajo este mandato fue creada la sub-área de memoria histórica de la CNRR, encarnada en el que hasta el 2011 se conoció como Grupo de Memoria Histórica $\mathrm{GMH}-$. Su función específica era elaborar el mencionado informe sobre las razones para el

\footnotetext{
${ }^{41}$ El informe ;Basta ya! Colombia: memorias de guerra y dignidad, contiene un anexo en el que especifican doce sentencias contra el Estado colombiano entre los años 2001 a 2012.

${ }^{42}$ Tomado de: http://www.vicepresidencia.gov.co/Es/iniciativas/Paginas/CNRR.aspx
} 
surgimiento y la evolución de los grupos armados ilegales, una tarea que, ajustada a las limitaciones impuestas por la misma ley que los creaba, tendría que omitir hablar de conflicto armado y, concomitantemente, de las víctimas cuyo daño no hubiera sido perpetrado directamente por grupos armados al margen de la ley. Adicional a esto, su narración no podría hacer mención de las responsabilidades del Estado en el devenir de la confrontación armada o, como muchos han optado por nombrar, la guerra que ha hecho parte de la historia nacional por extensos períodos. Más adelante veremos que el GMH no sólo hizo mucho más de lo que le había sido encomendado inicialmente, sino que desde el principio y antes de las perspectivas abiertas por la Ley de víctimas (2011), asumió una posición no sólo crítica de la Ley que posibilitó su existencia, sino abiertamente cuestionadora y, si se quiere, desafiante a la postura del gobierno de Uribe Vélez, puesto que desde la publicación del primero de sus informes incorporó la vetada noción de conflicto armado y eligió un caso en el que la participación de agentes del Estado como perpetradores estaba comprobada.

En sus cuatro años de existencia como $\mathrm{GMH}$, el grupo publicó una serie de informes sobre casos emblemáticos ${ }^{43}$, dos textos metodológicos y varios estudios temáticos que condensaban reflexiones y estadísticas acerca de problemas tradicionalmente vinculados al conflicto (como las disputas por la tierra y el lugar de las mujeres en medio de la confrontación). Su trabajo se vio potenciado a partir del 2011 cuando fue declarado un ente autónomo y vio ampliadas sus funciones al convertirse en Centro Nacional de Memoria Histórica por efecto de la Ley 1448 de ese año, y a la que en adelante nos referiremos como Ley de víctimas.

Esta ley, promulgada por un nuevo gobierno (bajo la presidencia de Juan Manuel Santos) centra su atención en las personas que han resultado afectadas por el conflicto armado sin estar necesaria o directamente involucradas en él, dando prioridad a la reparación y restitución de tierras de las víctimas del conflicto. Su descripción no deja dudas sobre el giro sustancial que implica respecto de la Ley de justicia y paz. Mientras la primera se describe como ley "por la cual se dictan disposiciones para la reincorporación de miembros de grupos armados organizados al margen de la ley, que contribuyan de manera efectiva a la consecución de la paz nacional y se dictan otras disposiciones para acuerdos humanitarios", la Ley de víctimas es descrita del siguiente modo: "por la cual se dictan medidas de atención, asistencia y reparación integral a las víctimas del conflicto armado interno y se dictan otras disposiciones". Este cambio de perspectiva implica un reconocimiento por parte del Estado de que no sólo existen los actores ilegales dentro del conflicto armado y es necesario tomar medidas para su desmovilización y reincorporación, sino que reconoce, además, que dicho conflicto no sólo existe sino que ha dejado víctimas que precisan también ser tenidas en cuenta, y no de manera marginal.

También en lo que respecta al deber de memoria del Estado encontramos transformaciones dignas de consideración: este no es definido ya en términos de algo acabado, como lo sería un "conocimiento" de causas, desarrollos y consecuencias del accionar de grupos armados ilegales, el cual es potestad del Estado elaborar y presentar, sino que se plantea como un proceso activo en el que está involucrado el conjunto de la sociedad. Literalmente, el artículo 143 de la Ley de víctimas lo plantea así:

El deber de Memoria Estado se traduce en propiciar las garantías y condiciones necesarias para que la sociedad, a través de sus diferentes expresiones tales como

\footnotetext{
${ }^{43}$ Esta noción será definida con amplitud cuando se presente la metodología de GMH.
} 
víctimas, academia, centros de pensamiento, organizaciones sociales, organizaciones de víctimas y derechos humanos, así como los organismos del Estado que cuenten con competencia, autonomía y recursos, puedan avanzar en ejercicios de reconstrucción de memoria como aporte a la realización del derecho a la verdad del que son titulares las víctimas la sociedad en su conjunto (República de Colombia, 2011).

Para el caso que nos ocupa, el GMH es un organismo del Estado que cuenta con competencia, autonomía y recursos para la reconstrucción de memoria acerca del conflicto armado interno. No se explicita, en principio, qué tipo de relato se debe construir, cuáles son los hechos que deben ser tenidos en cuenta, ni sobre qué actores del conflicto se centrarán los relatos o con base en qué elementos (testimonios, archivos de prensa, legajos judiciales, investigaciones de campo, etc...) han de ser elaborados. Lo que sí se establece con claridad en el único parágrafo al artículo que define el deber de memoria del Estado es que los organismos estatales involucrados en esta tarea no podrán construirse una memoria o verdad oficial:

En ningún caso las instituciones del Estado podrán impulsar o promover ejercicios orientados a la construcción de una historia o verdad oficial que niegue, vulnere o restrinja los principios constitucionales de pluralidad, participación y solidaridad y los derechos de libertad de expresión y pensamiento. Se respetará también la prohibición de censura consagrada en la Carta Política (Ley 1448 de 2011).

Parece haber aquí un panorama contradictorio: el Estado colombiano, en sintonía con las tendencias del presente y en respuesta a demandas que durante años hicieron asociaciones de víctimas y organizaciones de derechos humanos ${ }^{44}$, ha reconocido que tiene un deber de memoria para con las víctimas del conflicto armado y la sociedad, lo cual implica la elaboración de una memoria nacional acerca de dicho conflicto. Sin embargo, este parágrafo sugiere la pretensión de que esa memoria nacional no tenga un carácter oficial... ¿cómo escapar a serlo si se trata de un relato patrocinado y elaborado por el Estado?

Nos encontramos, ciertamente, ante un mandato paradójico desde varias perspectivas: en primer lugar, y de acuerdo con varios autores clásicos dentro del campo de estudios de la memoria, es difícil pensar en una memoria nacional que no sea, a su vez, una verdad oficial (Pollak, 2006; Todorov, 2000; Traverso, 2013). Por otra parte, es cuando menos extraño que un Estado cree por ley un organismo encargado de la reconstrucción de una memoria histórica, al tiempo que establece -en la misma ley- que ni sus elaboraciones ni las de ninguna entidad estatal podrán pretender erigirse como una historia o verdad oficial acerca del conflicto armado. Sin embargo, el simple hecho de que la escritura de informes particulares y generales sobre distintos casos y procesos asociados al conflicto esté a cargo de una entidad gubernamental, torna sus resultados en versiones oficiales, mínimamente en el sentido más técnico y amplio que puede otorgarse a lo oficial: aquello que tiene autenticidad y emana de la autoridad derivada del Estado, y no de entes particulares o privados.

En este punto es importante distinguir entre varias acepciones y concepciones acerca de "lo oficial", pues la falta de claridad respecto a tal noción en el parágrafo mencionado torna problemática su interpretación. En primera instancia, y de la manera más general posible, lo

\footnotetext{
${ }^{44}$ Amparo Sánchez, investigadora de la Corporación Región de la ciudad de Medellín, entidad que participó en la elaboración de varios de los informes correspondientes al departamento de Antioquia, recalcó en una entrevista la importancia de resaltar que la ley de víctimas no es "un regalo del Estado" sino el resultado de luchas que durante años llevaron a cabo las víctimas del conflicto armado para ser reconocidas como tales.
} 
oficial designa aquello que procede de entidades estatales, sin desconocer con esto las tensiones que pueden existir entre ellas y la dificultad de pensar el Estado con mayúscula como una unidad armónica capaz de producir discursos hegemónicos y sin fisuras que operen de la misma manera en todos los ámbitos y territorios de una nación. Se trata en esta acepción general de una cualidad que adquieren determinadas acciones y producciones en función del lugar del que proceden, sin que ello nos diga en principio nada más acerca de su contenido y su sentido. Sin embargo, cuando entran en juego asuntos polémicos o traumáticos, como es el caso de la violencia y el conflicto armado -cuyas implicaciones han tenido un hondo impacto social-, todo aquello que desde el Estado se diga o haga al respecto de manera formal, adquiriendo así un carácter oficial, es evaluado con lupa por críticos y opositores. Una de las posibles razones de esa evaluación minuciosa es que el contenido de las acciones, leyes y pronunciamientos oficiales tendrá un efecto específico sobre el universo de responsables y afectados por los hechos en cuestión, y el manto de la oficialidad puede haber dejado por fuera de su alcance personas y situaciones que, desde la perspectiva de determinados sectores de la sociedad, también debieron haber sido tenidos en cuenta. Las variaciones entre la Ley de Justicia y Paz y la de Víctimas, que expusimos anteriormente, son una clara muestra de cómo aquello que se presenta como oficial tiene consecuencias directas sobre hechos y sujetos: oficialmente, las características de una víctima con derecho a reparaciones económicas y simbólicas cambiaron sustancialmente de una ley a otra.

Aunque en el parágrafo que estamos considerando no se explicita a qué se alude con historia o verdad oficial, puede inferirse que tras la advertencia de no pretender construir una sola se están tomando en cuenta posiciones como las de Pollak (2006) o Todorov (2000), que parten de una desconfianza básica sobre el tipo de registros y recuerdos que tenderán a privilegiar las iniciativas estatales que, incluso en los tiempos que corren, pueden declinar sus pretensiones heroicas pero continuar evadiendo responsabilidades sobre hechos victimizantes de los que se ha vuelto un deber hablar.

En la tradición de los estudiosos sociales, todo aquello que proviene del Estado suele ser examinado con sospecha, dado el carácter hegemónico y masivo del que son susceptibles las medidas y pronunciamientos que de este poder proceden. El discurso oficial o la memoria nacional, en su sentido tradicional de construcción institucionalizada (Nora, 1984) o de narrativa que muestra a la nación como una comunidad imaginada (Anderson, 1983), con héroes y gloriosas batallas (Giesen, 2004), son vistos como la imposición del punto de vista de los vencedores y los poderosos, por contraposición al de los marginados, los excluidos, las minorías (Pollak, 2006; Blair, 2008). Estos serían portadores de memorias subterráneas que se oponen a la memoria oficial, que Pollak identifica con la memoria nacional. En las páginas iniciales de Memoria, olvido, silencio hace una crítica a la perspectiva de Halbwachs acerca de la memoria colectiva, a la cual le otorga, siguiendo a Durkheim, una fuerza instituyente y aglutinadora, en gran medida articulada a la memoria nacional. En contraposición a esto, Pollak reivindica el lugar central que la historia oral otorgó al análisis de las minorías, los marginales y los excluidos, resaltando lo que pueden aportar las memorias subalternas "que, como parte integrante de las culturas minoritarias y dominadas, se oponen a la «memoria oficial», en este caso a la memoria nacional" (Pollak, 2006, p. 18). Se trata de un abordaje que "hace de la empatía con los grupos dominados estudiados una regla metodológica y rehabilita la periferia y la marginalidad. Al contrario de Maurice Halbwacks (1925), este abordaje acentúa el carácter destructor, uniformizante y opresor de la memoria colectiva nacional” (Pollak, 2006, p. 18).

Esta descripción que de la memoria nacional retoma Pollak como necesariamente opresiva, destructora y hegemonizante, nos resulta cuando menos digna de interrogación a la luz de 
los procesos de memoria emprendidos en años recientes en Colombia por iniciativa del Estado, muchos de los cuales han retomado los emprendimientos de memoria que las organizaciones de víctimas, los sobrevivientes y familiares de algunas de ellas, las comunidades indígenas y afrodescendientes así como sectores de la sociedad civil habían iniciado para preservar del olvido el conocimiento de hechos atroces por los que han pasado distintas comunidades del país (GMH, 2009). Esto parece indicar que, en contravía de la afirmación de Pollak, las voces de los grupos aislados y dominados han cobrado relieve en la fabricación de la memoria nacional colombiana, una memoria que, además, y según dicta la tendencia del momento, no está centrada en gestas heroicas sino en hechos luctuosos, en vergüenzas del Estado.

Catalina Uprimny (2012) hace un análisis de la memoria en la Ley de víctimas, en la cual aparece como derecho (de las víctimas y de la sociedad) y como deber (del Estado). A la luz de los planteamientos de la Corte Interamericana de Derechos Humanos - CIDH-, que dictamina que la memoria debe ser considerada en sus dimensiones individual y colectiva, Uprimny concluye que la Ley "tiene problemas de sistematicidad y que no permite garantizar debidamente la dimensión individual del derecho a la memoria” (2012, p. 142), puesto que la definición del deber de memoria del Estado que se asume en el artículo 143 (incluyendo el parágrafo del que hemos venido hablando) no se entiende "como una medida de reparación de las víctimas, sino de construcción de memoria histórica" (2012, p. 142).

Para esta investigadora, el hecho de que la Ley cree un Centro de Memoria Histórica, si bien es importante para el conocimiento y reflexión acerca de la historia y características del conflicto armado, no constituye una medida reparatoria -ni siquiera simbólica- para las víctimas, quienes deben acudir a instancias judiciales para que, "caso por caso, los tribunales y jueces establezcan las medidas adicionales de reparación simbólica para garantizar su derecho a la memoria" (Uprimny, 2012, p. 140).

Pese a este análisis jurídico, es posible sostener que la forma en que el GMH ha estructurado su trabajo ha procurado integrar las perspectivas individual y colectiva, al hacer de los testimonios de las víctimas y sobrevivientes, y de la reivindicación de sus trayectorias y sus luchas, una de las principales fuentes alrededor de las cuales se estructuran sus informes, dirigidos a la sociedad colombiana como conjunto. Asimismo, hay un constante acompañamiento a las iniciativas de memoria y a los reclamos por la restitución de derechos emprendidos por las víctimas individuales y colectivas, de donde se desprende que el GMH, como entidad que encarna el deber de memoria del Estado, no ha limitado su labor al ejercicio investigativo, de redacción y difusión de los informes sino que, en su apuesta por otorgar voz y presencia a las víctimas, ha asumido tareas de denuncia, acompañamiento y reivindicación de luchas y derechos de las mismas.

Este compromiso decidido y manifestado explícitamente una y otra vez en los distintos informes y pronunciamientos públicos de los miembros del $\mathrm{GMH}$, evidencia un posicionamiento a favor de las víctimas el cual es justificado no sólo en términos humanitarios sino políticos, en el sentido de que plantea la necesidad de que la sociedad tenga en cuenta las vivencias de las víctimas para que se constituya un nuevo -o por lo menos distinto- orden estatal.

\subsection{Entre la paradoja y el desafío: conformación y acciones del Grupo de Memoria Histórica}

La Ley de Justicia y Paz fue la primera en sentar las bases para una preservación de la memoria de acontecimientos violentos, apoyada directamente por el Estado. Con tal fin, se 
creó la Comisión Nacional de Reparación y Reconciliación y su Grupo de investigación de Memoria Histórica que ha realizado informes, exposiciones y documentales sobre algunas de las masacres, tomas armadas, persecuciones y desplazamientos perpetradas por los grupos armados ilegales, tanto guerrilleros como paramilitares (en ocasiones en colaboración o con complicidad de las fuerzas armadas del Estado), a partir de un contacto directo con las víctimas.

Para presentar en detalle la labor del Grupo, citaremos in extenso la descripción que sobre sus funciones y la forma en que construyen los informes, plantean en su página web:

Memoria Histórica $(\mathrm{MH})$ es un grupo de investigación de la Comisión Nacional de Reparación y Reconciliación (CNRR) que tiene como objetivo elaborar y divulgar una narrativa sobre el conflicto armado en Colombia que identifique "las razones para el surgimiento y la evolución de los grupos armados ilegales" (Ley 975 de 2005), así como las distintas verdades y memorias de la violencia, con un enfoque diferenciado y una opción preferencial por las voces de las víctimas que han sido suprimidas o silenciadas. Además, el grupo formula propuestas de política pública que propicien el ejercicio efectivo de los derechos a la verdad, la justicia, la reparación y las garantías de no repetición.

[...]

La metodología implica ejercicios participativos y dialogantes con habitantes de las regiones donde sucedieron los hechos, la realización de talleres, conversatorios, entrevistas, exposiciones, trabajos fotográficos y audiovisuales, y la compilación de formas de expresión creadas por las propias comunidades. Por medio de este ejercicio de construcción colectiva, Memoria Histórica pretende otorgar un lugar privilegiado a las voces regionales y locales, especialmente a las voces de las víctimas ${ }^{45}$.

Este grupo está conformado, principalmente, por académicos y profesionales de las ciencias sociales y humanas y del Derecho, con una reconocida trayectoria en el abordaje de la violencia y los derechos humanos (Jaramillo, 2009, pp. 29-59). Su conformación tomó casi dos años, pues los miembros de la Comisión Nacional de Reparación y Reconciliación, que había seguido de algún modo las experiencias de otros países al ser estructurada alrededor de figuras notables de la sociedad ${ }^{46}$, consideraron que estaba fuera de su alcance la elaboración de un informe que explicara el surgimiento de los grupos armados ilegales, tal como establecía el mandato inicial de la Ley de Justicia y Paz, surgida bajo las directrices de un presidente que hizo de la negación del conflicto armado una estrategia privilegiada para ahondar en la deslegitimación de las guerrillas. Las referencias al conflicto en los pronunciamientos oficiales y en los medios de comunicación resurgirían después, una vez que el cambio de gobierno promoviera nuevamente no sólo su uso en el lenguaje oficial sino un reconocimiento legal de su existencia, alrededor del cual se estructuró la Ley de víctimas ${ }^{47}$.

45 Tomado de la presentación del Grupo de Memoria Histórica en la página web del CMH: http://www.centrodememoriahistorica.gov.co/index.php/somos-gmh/grupo-de-memoria-historica

${ }^{46}$ La conformación de la CNRR buscó otorgarle un carácter pluralista, la cual estaría reflejado en los perfiles diversos de sus integrantes y en el equilibrio regional, político y de género que se le imprimió. De la Comisión hicieron parte tanto figuras notables de la política y la academia, como representantes de las organizaciones de víctimas, funcionarios del Ministerio Público, activistas, consultores, investigadores e integrantes de entidades de cooperación (Jaramillo, 2011, p. 305).

${ }^{47}$ Véase al respecto el artículo ¿Qué significa el reconocimiento del conflicto armado por parte del Gobierno?, publicado por la Revista Semana el 4 de mayo de 2011. Disponible en: http://www.semana.com/nacion/articulo/que-significa-reconocimiento-del-conflicto-armado-parte-delgobierno/239313-3 
Tal postura estatal, como ya se ha dicho, tuvo cambios sustantivos en la transición entre Uribe y Santos, pues no sólo se volvió a hablar de conflicto armado sino que en el informe general sobre el conflicto, entregado públicamente por el Centro de Memoria Histórica el 24 de julio de 2013, se identifica al Estado y sus fuerzas armadas como actores del mismo y se hace un llamado al reconocimiento público de su responsabilidad, cosa que el presidente hizo efectivamente un día después, el 25 de julio, ante la Corte Suprema de Justicia ${ }^{48}$. Este pronunciamiento, que fue uno de los efectos inmediatos más importantes de la entrega del informe, tuvo poca resonancia en los medios de comunicación nacional; únicamente la Revista Semana le dedicó un artículo en su sitio web y publicó el discurso completo de Santos. En contraste con esto, varios medios internacionales que están haciendo un seguimiento pormenorizado del proceso de paz con las FARC, hicieron eco de este acontecimiento ${ }^{49}$.

Sin desconocer que sigue habiendo un abismo entre lo que se dice y lo que se hace, el hecho que se haya recuperado la noción de conflicto armado y que se haya producido, por primera vez en la historia, un reconocimiento de la responsabilidad estatal sobre el mismo, abre las puertas para transformaciones más estructurales, que sólo se sabrá si llegan a darse cuando haya pasado un tiempo prudencial desde estos pronunciamientos.

Volviendo sobre el proceso de conformación del Grupo de Memoria Histórica, es importante resaltar que esta vuelve a poner de manifiesto la relación estrecha y recurrente entre intelectuales y política que ha sido propiciada por diferentes gobiernos a lo largo de la trayectoria del conflicto, tal como vimos al inicio de este capítulo. Sin embargo, en el caso de GMH se da una experiencia de ruptura, pues no se trata de la búsqueda de académicos que hagan -nuevamente- un diagnóstico experto acerca de la situación del país, sino que se ponen en juego propósitos de comprensión que incluyan, de manera protagónica, la voz de las víctimas del conflicto. La definición de estas cuestiones tomó meses de discusión, pues la CNRR requería integrar un imperativo ético -la producción de una memoria plural en la que participara la sociedad civil que ha sido afectada por el conflicto- con un mandato político establecido en la Ley 975, que solicitaba la construcción de un informe especializado que explicara el origen y las lógicas de la confrontación armada en el país, pero teniendo en cuenta únicamente a los actores ilegales. Jaramillo (2011) reconstruye los intrincados debates que se dieron al interior de la CNRR, los cuales se nuclearon alrededor de dos posiciones: los que él denomina gobiernistas, que sostenían que era necesario tener un control absoluto sobre qué y cómo iba a decirse, y los técnicos, que le apostaban a que el informe fuera producido con suficiente autonomía académica y ética, bajo criterios metodológicos acordados en la Comisión. Tras un año de discusiones, argumentos y propuestas, se optó por perspectiva técnica, pero dejando claro que "no se trataría única y exclusivamente de un grupo de estudio sobre la guerra", según expresó Patricia Linares ${ }^{50}$. Los criterios mínimos sobre los cuales se acordó la constitución de GMH fueron los siguientes: 1) calidad académica de sus integrantes; 2 ) responsabilidad moral y ética frente a las víctimas; 3) carácter de organismo de investigación histórico, no judicial; 4) necesidad de elaborar una memoria que no tuviera únicamente perspectiva de pasado, sino también de futuro (posición que se alinea con las tendencias predominantes acerca de la función de la

\footnotetext{
${ }^{48}$ Cf. Santos reconoce responsabilidad del Estado en el conflicto. Revista Semana, 25 de julio de 2013. Disponible en: http://www.semana.com/nacion/articulo/santos-reconoce-responsabilidad-del-estado-conflicto/351988-3

${ }^{49}$ Las posiciones y efectos derivados de la presentación del informe ¡Basta ya! serán objeto de análisis en una futura tesis doctoral.

${ }^{50}$ Patricia Linares es abogada, y participó en la CNRR como representante del Ministerio Público. En la actualidad forma parte del equipo investigador de $\mathrm{CMH}$.
} 
memoria como un relato sobre el pasado que se construye en el presente con perspectivas de futuro); 5) autonomía académica, investigativa y operativa en el trabajo.

Estos criterios buscaban, de algún modo, proteger al naciente grupo de las inevitables sospechas de sesgo gubernamental que ya habían comenzado a recaer sobre la CNRR y que podían dificultar su trabajo, sobre todo en la medida de que la reconstrucción de los hechos que fueran a estudiarse debía realizarse de la mano de las víctimas y la sociedad civil. En algunos momentos se llegó a plantear la opción de crear el GMH como un organismo totalmente independiente del gobierno, pero finalmente se mantuvo la directriz de la Ley de Justicia y Paz de que fuera la CNRR (a través de una sub-área de memoria histórica encarnada en $\mathrm{GMH}$ ) la que se encargara de la elaboración sobre las causas y el origen de los grupos armados ilegales.

Una vez establecidos los criterios mínimos de funcionamiento, se procedió a la apertura de una convocatoria pública para designar a la persona que coordinaría el $\mathrm{GMH}$, quien debía acreditar el cumplimiento de los siguientes requisitos: 1) poseer un título de Doctorado en el área de las ciencias sociales y comprobada experiencia en investigaciones históricas; 2) ser un académico reconocido nacional e internacionalmente por sus estudios sobre la violencia, la cual sería evaluada en función de sus publicaciones sobre el tema y 3) demostrar experiencia y habilidad para el trabajo en equipo. Quien fuera elegido contaría con dos meses posteriores a su designación para presentarle a la CNRR una propuesta de trabajo en la que se detallara cómo iba a llevarse a cabo la función encomendada. A comienzos del 2007, y como resultado del proceso de selección, se nombró a Gonzalo Sánchez, reconocido investigador y profesor universitario, como coordinador de $\mathrm{GMH}$, que se constituyó oficialmente el 20 de febrero de 2007. La figura de Gonzalo Sánchez ha sido central en el análisis de la violencia en Colombia, y se trata de un asunto que ha atravesado su vida no sólo a partir de su formación profesional sino desde mucho antes, por sus propias experiencias de persecución y desplazamiento durante el período de La Violencia junto a su familia. Oriundo de un municipio del sur del país, nacido en los albores de la época de La Violencia (1945) en una familia campesina cuyo padre era liberal, tuvo que vivir desde niño con la zozobra de las amenazas contra su padre y los constantes desplazamientos forzados entre veredas de su lugar de origen y la capital del país, en donde sufrió momentos de miedo y de penuria (Cristancho, 2011). La violencia fue, para Sánchez como para muchos, una realidad de la que continuamente estaba escapando pero que no dejaba de habitar y, aunque luego de obtener varias becas para la realización de sus estudios, optó por desenvolverse en la Universidad Nacional en carreras que no lo abocaban directamente al tema de la violencia política (estudió derecho y filosofía, simultáneamente), terminó por retornar a ella ya no como víctima sino como investigador tras obtener una beca más para realizar un posgrado por ser el mejor egresado de su promoción universitaria. Esta beca lo llevó a Londres, en 1972, a cursar estudios en historia y en ciencia política y marcó el inicio de una nueva relación con un pasado traumático que, a la vez que le era propio, coincidía con los problemas y las preguntas de todo un país. En sus propias palabras:

[...] mis primeras inclinaciones cuando ingresé como estudiante de la Universidad Nacional, en 1965, fueron por dos carreras que cursé simultáneamente: el Derecho y la Filosofía, es decir, por el mundo de las formas y de las abstracciones, muy ajenas a mis preocupaciones de infancia y temprana adolescencia, pese incluso a mi militancia política en la izquierda durante aquellos turbulentos y creativos años de la Universidad.

Vano resultó el intento de evasión y de deshacerme de ese pasado traumático. Apareció como objeto intelectual, paradójicamente estando lejos de 
Colombia, cuando tuve que pensar en el tema para mi monografía de posgrado en Inglaterra, hacia 1974-75. Desde entonces quedé poseído por la problemática de la violencia: mis estudios se volvieron en cierta manera autoanálisis, exorcismo o catarsis de mis temores y aprensiones infantiles, intento (tal vez fallido) por entender ahora ese monstruo que dominó mis primeros años y que ha seguido marcando la historia del país y mi propia biografía. (Sánchez, 2003

Durante su paso por la Universidad Nacional, como se desprende de la cita anterior, Sánchez militó en movimientos sociales de izquierda y se aproximó a la obra de Marx, Lenin, Gramsci, entre otros importantes pensadores de esta tendencia (Cristancho, 2011). Sin embargo, no se le conoce vinculación con ningún partido político en particular y, aunque en diversos gobiernos ha prestado sus servicios como asesor experto e investigador en temas de violencia, no lo ha hecho en representación de movimiento o partido alguno, sino como intelectual independiente y profesor de la Universidad Nacional.

La coordinación del GMH sería la segunda ocasión en que se le confiaba a Sánchez la coordinación de una estrategia gubernamental para la aproximación al fenómeno de la violencia, pero con presupuestos, recursos y tiempos muy diferentes a los de la experiencia de 1987. En primer lugar, el GMH no estaba pensado como una comisión de estudio y lo que se estaba solicitando no era un dictamen experto sino una reconstrucción de las memorias de los enfrentamientos armados entre distintas agrupaciones ilegales y el Estado, si bien con cierto sesgo que ya hemos señalado. Además, por el carácter de la CNRR, se empezó a perfilar tempranamente que era importante que dicha reconstrucción tuviera en cuenta una pluralidad de voces, en particular las de personas que han sufrido en carne propia los embates de la confrontación armada. Esto suponía la conformación de un equipo que estuviera en condiciones de hacer un trabajo de campo que, además de la observación y las entrevistas, propendiera por el establecimiento de una relación de confianza con personas que no sólo habían sido testigos y/o víctimas de crímenes y vejámenes de todo tipo, sino que podían seguir estando bajo amenaza, pues el conflicto no ha cesado. En segundo lugar, el Estado, en cabeza de la CNRR, destinó algunos recursos financieros para la investigación pero también dejó abierta la posibilidad de buscar apoyo de organismos internacionales, gracias a lo cual el GMH consiguió llevar adelante una serie de trabajos metodológicos, conceptuales y de casos emblemáticos previos a la entrega de su informe general sobre los grupos armados ilegales, única exigencia que estaba contemplada inicialmente en la Ley de Justicia y Paz. Esta búsqueda de cooperación internacional ha implicado que la labor de reconstrucción esté permanentemente acompañada de una especie de lobby con diferentes organismos que hacen parte de las empresas globales humanitarias, lo cual podría, desde cierta perspectiva, percibirse como una limitación de la autonomía académica del GMH (Jaramillo, 2011), al condicionar sus producciones a lo que Crenzel (2006) denomina narrativa humanitaria $a^{51}$, y sobre lo que Vecchioli $(2013$, p. 10) advierte que puede tener efectos de pérdida de rigor analítico si el investigador no logra mantener cierta distancia desde la cual aproximarse a lo que quiere comprender yendo más allá de las trampas de la empatía o la compasión. Después de leer los informes del Grupo, especialmente en los apartados que se refieren a su concepción de las víctimas, queda en evidencia que, como equipo, han hecho un esfuerzo, por no caer en estas trampas advertidas por Vecchioli y Crenzel, pues aunque apelan a llamados éticos y morales para sensibilizar a la sociedad sobre la situación de las personas que se han visto afectadas de diversas maneras por el conflicto, presentan también un compendio detallado de las

\footnotetext{
${ }^{51}$ Crenzel (2006, p. 44) define la narrativa humanitaria como aquella que desplaza la clave revolucionaria de las denuncias y convoca "desde un imperativo moral, a la empatía con la experiencia límite sin historizar el crimen ni presentar vínculos entre el ejercicio del mal, sus perpetradores y sus víctimas”.
} 
razones históricas de la confrontación, los múltiples factores y actores involucrados y la compleja red de relaciones y responsabilidades que van desde la perpetración directa de crímenes hasta la legitimación de prácticas delictivas por parte de ciertos sectores las autoridades y la ciudadanía. En la introducción al primero de sus informes, por ejemplo, declaran:

Hechos, contextos y actores son las tres dimensiones desde las cuales se aborda la trama que se teje entre violencia y memoria. Pero el trabajo de la memoria exige no sólo rigor académico, sino además compromiso ético, capacidad y sensibilidad para hacer propia la experiencia humana del dolor y el sufrimiento ajeno. En un contexto de tragedias humanas como el nuestro, la investigación debe ser social no sólo por su objeto, sino también por su vocación. (GMH, 2008, p. 26. El subrayado es nuestro).

Aquí se evidencia una postura ética frente a la forma en que serán abordadas las "fuentes" humanas que, más que ser consideradas como objetos de investigación que pueden aportar datos para estructurar los informes sobre el conflicto, son tomadas en su dimensión subjetiva, poniendo especial atención a su humanidad y a las experiencias de sufrimiento por las que han pasado muchas de las personas con las que se tendrá interacción en el proceso de elaboración de los textos que componen los informes. Sin embargo, no deja de resaltarse la importancia, también del rigor académico, a partir del cual se definen las tres dimensiones centrales en cada una de sus construcciones, a saber: hechos, contextos y actores $^{52}$. Además, en distintos apartados de su vasta producción, hacen énfasis en que el reconocimiento y sensibilización con respecto a los padecimientos de las víctimas es necesario, pero en ningún caso suficiente para crear unas condiciones mínimas de transformación que hagan posible un reconocimiento de cómo el conflicto armado ha afectado ampliamente la dinámica del país, aun cuando no haya tocado directamente al grueso de la población. En este sentido, Sánchez, en el prólogo al ¡Basta ya!, expresa:

[... ] aunque el conflicto armado en el país ha cobrado millares de víctimas, representa para muchos conciudadanos un asunto ajeno a su entorno y a sus intereses. La violencia de la desaparición forzada, la violencia sobre el líder sindical perseguido, la violencia del desplazamiento forzado, la del campesino amenazado y despojado de su tierra, la de la violencia sexual y tantas otras suelen quedar marginadas de la esfera pública, se viven en medio de profundas y dolorosas soledades. En suma, la cotidianización de la violencia, por un lado, y la ruralidad y el anonimato en el plano nacional de la inmensa mayoría de víctimas, por el otro, han dado lugar a una actitud si no de pasividad, sí de indiferencia, alimentada, además, por una cómoda percepción de estabilidad política y económica.

La construcción de memorias emblemáticas de la violencia y de sus resistencias puede y debe realizarse tanto desde los centros como desde la periferia del país. Tanto desde los liderazgos nacionales y los liderazgos enraizados en las regiones, como desde los pobladores comunes y corrientes. La democratización de una sociedad fracturada por la guerra pasa por la incorporación, de manera protagónica, de los anónimos y de los olvidados a las luchas y eventualmente a los beneficios de las políticas por la memoria.

Es indispensable desplegar una mirada que sobrepase la contemplación o el reconocimiento pasivo del sufrimiento de las víctimas y que lo comprenda como resultante de actores y procesos sociales y políticos también identificables, frente a los cuales es preciso reaccionar. Ante el dolor de los demás, la indignación es importante pero insuficiente. Reconocer, visibilizar, dignificar y humanizar a las víctimas son

\footnotetext{
${ }^{52}$ En el último capítulo veremos que, efectivamente, esas tres dimensiones son ejes articuladores que pueden rastrearse tanto en los informes sobre casos emblemáticos como en el informe general sobre el conflicto armado.
} 
compromisos inherentes al derecho a la verdad y a la reparación, y al deber de memoria del Estado frente a ellas.

Para $\mathrm{GMH}$, el posicionamiento de las voces de las víctimas en la esfera pública es un eslabón central de la forma en que definieron llevar a cabo su tarea. En sintonía con los movimientos que dieron origen al campo de los estudios de memoria (atravesados de manera primordial por la experiencia del Holocausto nazi), la apuesta ética del Grupo está claramente orientada a la reivindicación de las memorias de las víctimas y a la restitución de su dignidad y humanidad, mancilladas y, en casos extremos, arrebatadas, por diferentes actores armados que se arrogaron un poder sobre existencias, cuerpos y territorios.

En consonancia con estos propósitos, la composición del equipo de trabajo contempló la confluencia de investigadores con trayectorias y características diversas: por una parte profesionales con la sensibilidad humanitaria que, desde el inicio de su trabajo, declararon como factor decisivo y característico en el cumplimiento de su labor (lo que incluía contar con investigadores capaces de establecer vínculos cercanos con las víctimas) y, por otra parte, académicos un poco más asépticos -por decirlo de algún modo- que aportan una mirada estructural y, si se quiere, menos apasionada de la difícil realidad que están estudiando. Jaramillo (2011) identifica tres tipos de investigadores: los académicos expertos, los sensibles exploradores y los activistas. Los primeros son investigadores especialistas en determinadas líneas temáticas, con una amplia trayectoria en el estudio de problemáticas asociadas a la violencia y que, por tanto, gozan de una cierta autoridad en el país y son referentes obligados en asuntos como las dimensiones sociales y regionales de la memoria, las relaciones entre poder y narcotráfico, derechos humanos, lógicas del terror, derecho y justicia transicional. Entre ellos, podemos identificar a Álvaro Camacho, participante juntos con Gonzalo Sánchez de la Comisión de estudios sobre la violencia de 1987; María Victoria Uribe, antropóloga, exdirectora del Instituto Colombiano de Historia y Antropología y autora de varios estudios sobre los aspectos simbólicos de la violencia; e Iván Orozo, abogado y experto en el tema de justicia transicional, entre otros. Los segundos tienen en común estrategias innovadoras para acercarse a la dimensión emocional de las experiencias vividas por las personas en contextos de violencia, amplia experiencia en trabajos directamente en los territorios o el abordaje de temas que no habían sido explorados en las anteriores comisiones. Las características de este segundo grupo de investigadores le ha permitido al GMH franquear las áreas típicas de investigación y, no menos importante, la desconfianza y reticencia con que suelen recibir las comunidades victimizadas a aquellos que van a estudiarlos como si fueran extraños fenómenos, hurgan en el pasado, reabren heridas, obtienen el material que necesitan, y se van. A partir de estrategias audiovisuales o de talleres y encuentros informales que dan vía libre a la catarsis colectiva y a la elaboración de los estragos de la guerra, este subgrupo de investigadores aporta un ingrediente de humanidad -no necesariamente humanitarismo- a una labor que demanda, además de rigor, sensibilidad. Algunos exponentes de estas características dentro de $\mathrm{GMH}$ serían Jesús Abad Colorado, reputado fotógrafo del conflicto, quien ha encontrado en la imagen una vía fructífera para transmitir los horrores e ironías del conflicto, pero también la solidaridad, la esperanza y la resistencia; María Emma Wills, una comprometida estudiosa de la situación de las mujeres en medio del conflicto, o Martha Nubia Bello, trabajadora social con experiencia en trabajo con comunidades marginadas. Por último, los activistas teóricos son aquellos intelectuales que buscan ir más allá del diagnóstico y asumir su trabajo desde un compromiso con la proyección de sus hallazgos, lo cual consideran parte fundamental de la responsabilidad social en un país en guerra. La posición que asumen es entonces la de testigos de las huellas del horror y hacen eco de sus sentidos, y no sólo la de meros investigadores que transmiten datos. Aquí son importantes los nombres de León Valencia, exguerrillero del M-19, periodista, columnista y 
director de la Corporación Nuevo Arcoiris, que se dedica, entre otras cosas, a la investigación y denuncia de delitos políticos en complicidad con grupos armados; César Caballero, politólogo experto en cifras del conflicto y consultor del PNUD en Colombia, o Rodrigo Uprimny, abogado, director del Centro de Investigación Dejusticia y columnista del diario El Espectador, desde donde genera opinión y promueve la difusión crítica de cifras y datos relacionados con el conflicto armado y la aplicación del modelo de justicia transicional.

Esta confluencia de miradas y estrategias tan diversas hace de los informes del GMH un producto cultural rico en perspectivas y voces, que se convierte en un experimento novedoso, algo abrumador por su volumen y extensión ${ }^{53}$, así como por la densidad de sus contenidos, pero rico en cuanto a las posibilidades de interpretación que ofrece y las que invita a realizar. Muestra de esto son los distintos tipos de informes que han elaborado, pues además de los centrados en casos emblemáticos, han editado varios sobre temas específicos, como el lugar de las mujeres en la guerra en distintos lugares, como la Costa Caribe (al norte del país) o el bajo Putumayo (en la zona selvática del sur del territorio); la percepción y efectos de la Ley de Justicia y Paz; la diferencia entre verdad judicial y verdad histórica; el fenómeno del secuestro; la problemática de la tierra y los retos para la reintegración de miembros de grupos armados ilegales tras la culminación exitosa de procesos políticos de negociación. Cada uno de estos estudios ahonda en aspectos particulares asociados al conflicto, lo que da cuenta de una mirada que no es reduccionista y que, por el contrario, ha procurado abarcar un espectro amplio de factores para explicar la magnitud, complejidad y duración de la violencia y el conflicto armado en el país. Por ejemplo, en cuanto al polémico asunto de la justicia transicional instalada en Colombia a partir de la Ley de Justicia y Paz, aun cuando lo que se estaba negociando en el momento de su proclamación no era el fin del conflicto, el GMH, amparado en la concepción de Nora (1984) de los escenarios judiciales como lugares de memoria, sostiene:

\begin{abstract}
[... J Justicia y Paz no es solo un proceso penal especial que intenta lidiar con criminales de lesa humanidad mientras establece las condiciones de toda futura negociación con grupos armados ilegales, sino que también erige nuevas instancias en la construcción colectiva de una memoria nacional sobre el pasado violento. En ese sentido, la escena judicial de Justicia y Paz hace más que afirmar la fuerza de la tradición cívica y jurídica colombiana, en la medida en que, articulada a un complejo institucional llamado "sistema de Justicia Paz", establece lugares, fuentes y énfasis de un relato que debe dar cuenta del conflicto armado y de la violencia paramilitar. Habría que decir, en todo caso, que la escena judicial de Justicia y Paz es un lugar de la memoria en un sentido no previsto por el concepto de Nora. En efecto, la justicia transicional es transicional precisamente en la medida en que tiene como una de sus finalidades contribuir a gestionar un cambio profundo en la identidad nacional y con ello en la memoria colectiva que le sirve de sustento. En ese sentido, asistimos a un fenómeno de debilitamiento de una tradición de olvido de la atrocidad y de invisibilización de las víctimas, y de sustitución de la misma por una tradición de recuerdo de la atrocidad bajo premisas de visibilización y privilegio del punto de vista de las víctimas. (GMH, 2012, p. 20).
\end{abstract}

Que los informes no estén ceñidos a los esquemas de la academia, si bien puede convertirlos en objeto de crítica para quienes desde allí los examinan, tienen otras potencialidades que, miradas desde los intereses de un Estado que pretende recomponerse y trabajar en la vía de la superación de las lógicas violentas del conflicto armado, merecen

\footnotetext{
${ }^{53}$ A diciembre de 2013 se habían presentado más de veinte informes, cada uno con una extensión en promedio de 300 páginas.
} 
también ser reconocidas. La clara apuesta por posicionar valores democráticos y de convivencia, y el llamado a que la sociedad haga un trabajo de reflexión -y hasta contriciónpor la indiferencia y la indolencia hacia las víctimas del conflicto, sitúa los informes y demás productos y estrategias del $\mathrm{GMH}$ en un horizonte que, conjugando lo académico con lo político, interpela a la sociedad como totalidad y busca transformar aspectos culturales tales como los valores, las prácticas, los rituales de vida y muerte, o los sentidos colectivos sobre la memoria y la guerra.

En Colombia, a lo largo de la historia, los gobiernos han establecido comisiones o grupos para acercarse a los fenómenos de la violencia y el conflicto cuyos miembros han tenido características bastante específicas: la comisión de 1958 buscó a destacadas figuras que ayudaran al posicionamiento del discurso del Frente Nacional, mientras la de 1987 convocó a expertos que pudieran dialogar con el Estado. Por su parte, en esta última experiencia que venimos analizando, se conformó un grupo de intelectuales que vinculan teoría y acción, en el sentido de que no se trata únicamente de elaborar diagnósticos causales sino también de hacer proyecciones de futuro para un país en guerra. Para Sánchez, se trata de un intelectual que "sepa insertarse dentro de los desafíos que van a plantear las demandas objetivas de un contexto de masacres y las demandas subjetivas de las víctimas, y que sepa conciliarlas". (Sánchez, 2011, citado por Jaramillo, 2011, p. 324).

\subsubsection{Trabajo con-sentido. Fases y metodología del GMH}

Una vez conformado el grupo con las características que acabamos de mostrar, se pasó al establecimiento de una ruta de trabajo por fases que ha tenido variaciones en función de las transformaciones del grupo a partir del 2011, cuando tras la aprobación de la Ley de Víctimas, adquirió nuevas responsabilidades y funciones. La primera fase fue el diseño y planeación de actividades, que incluyó discusiones para la formulación de las principales líneas de investigación y las estrategias que se emplearían para llevarlas a cabo, una de las cuales sería la de los casos emblemáticos; la segunda fue la investigación sobre el primero de estos casos, a manera de prueba piloto, correspondiente a la masacre continuada ${ }^{54}$ de Trujillo, población ubicada en el centro del país en la que se presentaron, entre 1988 y 1994 , sistemáticos actos violentos asociados al conflicto armado, varios de ellos con participación directa de miembros de la fuerza pública. Por estos hechos, la Corte Interamericana de Derechos Humanos señaló en 1995 al Estado colombiano como responsable de una de las masacres, ocurrida entre el 29 de marzo y el 17 de abril de 1990, por la cual han sido condenados un narcotraficante y paramilitar -Henry Loaiza, alias "El Alacrán" - y un coronel del ejército ( $r$ ) -Alirio Antonio Urueña, prófugo de la justicia-, en los años 2009 y 2010 respectivamente. La tercera fase consistía en el desarrollo de nuevos proyectos de investigación sobre casos emblemáticos, pero también sobre temas específicos vinculados a la dinámica de la guerra: la tierra en disputa, el lugar de las mujeres en medio del conflicto, el secuestro, entre otros. La última fase habría sido la redacción y divulgación del informe final sobre el conflicto, con lo cual se daría por concluida la tarea que les había sido encomendada por la Ley de justicia y paz. Sin embargo, como veremos en el apartado

\footnotetext{
${ }^{54}$ Asumiendo una postura política y simbólica que reconoce "la dimensión colectiva y prolongada de los crímenes que tuvieron lugar en esta zona [de la provincia] del Valle, destacando al mismo tiempo la crueldad y la sevicia en la ejecución de los hechos delictivos", GMH opta por dar esta denominación a los hechos violentos que se sucedieron en Trujillo y que, para los investigadores, no han concluido aún, pues en el momento de la realización del informe persistían las amenazas, se presentaban acciones vandálicas y profanaciones sobre el monumento a las víctimas que se hizo en el pueblo y no se había concretado ninguna condena sobre los responsables de los hechos. En este sentido, el título del informe correspondiente a este caso resulta elocuente: Trujillo, una tragedia que no cesa. (GMH, 2008).
} 
siguiente, con la creación del Centro de Memoria Histórica en 2011, el horizonte de labores se vio ampliado y el deber de memoria del Estado cobró una relevancia mayor que abarca una serie de acciones adicionales a la presentación de un informe general sobre el conflicto armado.

Nos interesa en este momento presentar y discutir la metodología de trabajo del GMH desde sus inicios. En ella es central el estudio de casos concretos de incursiones violentas de los grupos armados en distintas poblaciones, o acciones sistemáticas y reiteradas de amedrentamiento a lo largo de los años. Tales casos son seleccionados conjuntamente por los investigadores y actores regionales con el fin de mostrar las disputas en juego en la guerra, las lógicas y mecanismos de los actores del conflicto, el papel de la población civil y los efectos pasados y presentes sobre la comunidad que vivió los acontecimientos, y tiene en cuenta el conocimiento previo de los investigadores, las características intensificadas de los hechos (persistencia en el tiempo, número de muertos, masividad de los estragos...), además de irse nutriendo de las menciones o denuncias que hacen personas de a pie en las presentaciones públicas de los informes ${ }^{55}$.

La noción de «casos emblemáticos» es ampliamente usada por el Grupo Memoria Histórica para referirse a su metodología de investigación, pero no es del todo clara su definición. En uno de sus textos iniciales, titulado Recordar y narrar el conflicto, son descritos de la siguiente manera:

\begin{abstract}
El Área de MH ha decidido contar la memoria histórica del conflicto armado a partir de "casos emblemáticos" seleccionados entre investigadores y actores regionales para, por medio de ellos, ilustrar los conflictos y disputas de la guerra, las lógicas que movían y mueven a los actores armados, los mecanismos que cada actor utilizaba y sigue utilizando en ciertas regiones para avanzar, dominar y defender sus intereses, el papel de la población civil y los impactos que los eventos tuvieron y siguen teniendo sobre la vida comunitaria y regional. Por medio del caso emblemático se reconstruye un entramado histórico que no solo se detiene en los hechos puntuales sino que además devela lo que sucedió antes o después del evento. A través de él, se busca poner en evidencia los procesos que estaban desenvolviéndose en su entorno y que le otorgan su significado político. Los casos permiten además, producir una memoria histórica anclada en eventos o situaciones concretas desde los cuales se conectan las vivencias personales con los contextos más amplios en los que se inscriben los hechos y los discursos en los que se registran. (GMH, 2009, p. 24).
\end{abstract}

Esta es la descripción más detallada que se encuentra en la producción del Grupo acerca de este tópico, pero como puede notarse se trata de una noción un tanto ambigua, que en un principio pareciera emparentada con la categoría más amplia y generalizada en la investigación cualitativa de «estudio de caso». Sin embargo, al hablar de emblemático, se indica que se trata de un caso especial, poco corriente, cuya dimensión -de violencia en este caso- es mayor y sobrepasa los límites de los hechos habituales enmarcados en el conflicto. Además, se trata de casos que, simbólica y estructuralmente, pueden relacionarse con la dinámica general del conflicto colombiano, siendo posible encontrar en ellos los mismos actores, así como justificaciones y formas de proceder similares. Esto los convierte

\footnotetext{
${ }^{55}$ Mauricio Builes, comunicador del CNMH, comentó en una entrevista personal que la investigación del caso de la vereda El Placer, en el departamento del Putumayo (sur del país), surgió porque en una de las versiones de la semana por la memoria, una mujer se acercó a los investigadores y les narró los constantes asedios y disputas de los que han sido testigos y víctimas en ese municipio por cuenta de los cultivos ilícitos cuyo control buscan tener tanto guerrillas como grupos paramilitares. De otro modo, afirmó Builes, difícilmente se habrían enterado de esta situación y, lógicamente, el caso no habría sido documentado.
} 
en hechos clave para la comprensión general -nacional- de los modos de funcionamiento del conflicto.

Además de estas características simbólicas, los casos emblemáticos constituyen también una decisión pragmática para poder documentar un conflicto armado tan vasto como el colombiano. En un principio, la intención del GMH era estructurar sus relatos alrededor de masacres aunque, como veremos en el último capítulo, esta terminó por ser una entre otras modalidades de la guerra que se han registrado en los informes. Aun si sólo se hubiera ocupado de las masacres habría sido un «imposible empírico» ${ }^{56}$ abarcarlas a todas (más de 2505 entre 1982 y 2008, según datos de la (NRR). Ante este panorama, se optó por seleccionar casos que condensaran contextos, procesos y actores, procurando que contaran con las siguientes características: 1) permitir ilustrar procesos y tendencias de la violencia, 2) explicar las causalidades de la violencia, los discursos y representaciones de las víctimas y los perpetradores, 3) recoger e integrar memorias aisladas, con el fin de lograr una convergencia de voces sobre los acontecimientos investigados, lo cual, al final, permitiría elaborar un relato global interpretativo.

Para los investigadores del $\mathrm{GMH}$, esta metodología hace posible que no importe tanto el caso en sí mismo, sino cómo se articula a la historia regional y local. Además, con los casos emblemáticos se procuraba "descentrar la memoria, y a pesar de que los casos eran pocos frente a la magnitud de la guerra, con los seleccionados se buscaría que lo local y lo regional sobresaliera, ya que la memoria no podía ser concentrada en un solo lugar del país, ni en un solo escenario de narración y enunciación" (Jaramillo, 2011, p. 335).

La intención original de focalizar el análisis del conflicto armado alrededor de la figura de la masacre se debía a que varios de los miembros del equipo de trabajo consideraba que esta modalidad se había convertido en la marca específica de la guerra en el país. En términos netamente jurídicos, se define como masacre el "homicidio intencional de cuatro o más personas en estado de indefensión y en iguales circunstancias de modo, tiempo y lugar". (GMH, 2010, p. 33). Gonzalo Sánchez, director general tanto del Grupo como del Centro de Memoria Histórica, señala en el prólogo al informe sobre Remedios y Segovia (2010), que se trata de un término ampliamente usado en el lenguaje político colombiano desde la época de La Violencia, en la década del cincuenta. En ese entonces era usado para referirse a asesinatos brutales y masivos, llevados a cabo con tal nivel de sevicia que provocaban el abandono de los territorios por parte de los pobladores que eran testigos de los mismos o que se encontraban en los caminos con los cadáveres torturados y mutilados. Estos eran abandonados justamente con el propósito de generar terror y disuadir a la gente de oponerse al grupo dominante de turno. Casi idéntica práctica retornó con una gran intensidad a partir de la década del ochenta, siendo usada por distintos grupos armados como forma de imponer su poderío y desterrar a miembros y simpatizantes de grupos adversarios. Para Sánchez: "Las masacres y la violencia generalizada develan concepciones del territorio, de la política, del adversario y del orden social, que vienen quizás de muy atrás, de un pasado que habría que rastrear en la configuración y representaciones del campo político en Colombia" (GMH, 2010).

El primer informe del GMH evidencia la fuerza y persistencia de esta intención inicial, pues se ocupa justamente de la masacre de Trujillo. En la introducción, Gonzalo Sánchez explica algunas de las razones que llevaron a su elección como caso inaugural para la serie de sus

\footnotetext{
${ }^{56}$ Esta expresión fue usada por Gonzalo Sánchez y otros miembros de GMH en las entrevistas concedidas a Jefferson Jaramillo para el desarrollo de su tesis doctoral.
} 
informes. De ellas llama la atención que no menciona únicamente las características de la violencia presentada en el pueblo, que evidencian los nexos entre narcotráfico, paramilitarismo y acción estatal que son rastreables en muchas regiones del país, sino que señala también este lugar como escenario de la amnesia de los colombianos en conjunto sobre la barbarie que los ha acechado desde hace décadas:

\begin{abstract}
No sólo sus vecinos del orden regional desconocen o han olvidado lo sucedido, sino que más aún, respecto a esos eventos existe lo que pudiéramos llamar una desmemoria nacional, como en efecto lo han resentido las víctimas. Volver la mirada a Trujillo es entonces un primer ejercicio en la misión de convocar la solidaridad ciudadana y mostrarle al país que los hechos de Trujillo pertenecen al pasado nacional. Trujillo es, en más de un sentido, Colombia. Es preciso interpelar por tanto no sólo al Estado, sino también a toda la sociedad por los silencios y los olvidos que prosperaron en torno a la masacre; por haberse negado a aceptar lo que parecía inenarrable, inaceptable o imposible, pero que en verdad era muy real. (GMH, 2008, p. 11).
\end{abstract}

Esta idea consignada en la primera de las producciones del $\mathrm{GMH}$ es un claro reflejo de la postura desde la cual van a asumirse las tareas que permitan dar cumplimiento a un mandato legal que, de algún modo, le asignó a esta entidad funciones de esclarecimiento histórico. Sus elaboraciones no serán meros relatos descriptivos de acontecimientos atroces con la frialdad que podría esperarse de una mirada académica que no se detiene en los estragos subjetivos de los mismos sino fundamentalmente en la compresión de procesos históricos y sociológicos a los que subyace una lógica que puede ser develada. Esto se hace, en parte, al contextualizar los hechos de los que se ocupan las investigaciones y mostrar las complejas dinámicas del conflicto armado, pero el lugar de denuncia y la interpelación al Estado y a la sociedad es una constante que atraviesa los informes.

Pese a lo necesarios que puedan ser estos llamados desde el punto de vista de la construcción de cierta suerte de civilidad, vuelve a nosotros la pregunta por si es posible acusar de amnesia a todo un país cuando, en muchas ocasiones hay un vasto desconocimiento de los hechos, bien porque han sido silenciados por diversas vías (ausencia de denuncias de las víctimas, amenazas de los victimarios, desinterés de los medios de comunicación, censura de los gobiernos locales...) o porque, aun a sabiendas del contexto de conflicto armado, prima en muchos ciudadanos la tendencia a no querer saber nada de eso, que los conduce a ignorar deliberadamente las noticias, relatos o testimonios que evidencian la crudeza de una realidad que no se asume como propia.

Por estas razones nos parece que el segundo argumento de Sánchez es más sólido: no apela a la desmemoria colectiva sino a la decisión de muchos de "negarse a aceptar lo que parecía inenarrable, inaceptable o imposible", cosa que ha ocurrido en todas las sociedades afectadas por eventos atroces y que no tiene sólo una cara: muchas veces la sociedad no quiere escuchar, pero a veces son las mismas víctimas las que se rehúsan a evocar (Pollak, 1986,2006; Semprún, 1995). Lo interesante en este caso es descubrir de qué medios se vale el $\mathrm{GMH}$ para producir un efecto de sacudida en la sociedad, a qué estrategias apela, cómo hace visibles sus producciones ${ }^{57}$. Es justamente en este punto en el que se vuelve determinante el carácter estatal del $\mathrm{GMH}$, pues los recursos con que cuenta, no solamente económicos sino simbólicos, maximizan las posibilidades de circulación de sus informes y demás producciones.

\footnotetext{
${ }^{57}$ En el tercer capítulo examinaremos un poco este punto, el cual esperamos profundizar en la tesis doctoral.
} 
¿Podría equipararse esto que hace el GMH con una especie de memoria militante, moralizante, plegada a la versión de las víctimas? ¿O el GMH logra en sus informes el cometido de aportar a una memoria ejemplar sin llegar al extremo de pretender imponer una visión encantada -como advierte Vecchioli- de los relatos de las víctimas? En el tercer capítulo, dedicado al análisis del contenido del informe ¡Basta ya! y algunas otras producciones del Grupo, nos ocuparemos de este asunto. Por ahora, baste con mencionar que desde el inicio de sus labores en el año 2007 y hasta mediados de 2013, el GMH ha publicado diez informes sobre casos emblemáticos, dos guías metodológicas sobre la construcción de memoria histórica en tiempo de guerra, seis informes temáticos, una encuesta nacional sobre la percepción de los colombianos acerca del proceso de justicia y paz a siete años de su implementación y un informe general sobre el conflicto armado. La mayoría de estos insumos constan de un componente escrito y de material audiovisual como documentales o discos musicales grabados por los sobrevivientes en el marco de la investigación ${ }^{58}$.

\subsubsection{La voz de las víctimas}

La Ley 1448 de 2011, conocida justamente como Ley de víctimas y restitución de tierras, ofrece una definición de las mismas que busca ante todo delimitar quiénes tienen derecho a algún tipo de indemnización o reparación administrativa por parte del Estado colombiano. El concepto de reparación ${ }^{59}$, no incluye las acciones humanitarias y de asistencia que son competencia de las entidades estatales, a los cuales tienen derecho todos los ciudadanos colombianos, independientemente de si son o no víctimas directas del conflicto armado. De este modo, para los efectos de la Ley de víctimas, se consideran víctimas "aquellas personas que individual o colectivamente hayan sufrido un daño por hechos ocurridos a partir del 1enero de 1985, como consecuencia de infracciones al Derecho Internacional Humanitario o de violaciones graves y manifiestas a las normas internacionales de Derechos Humanos, ocurridas con ocasión del conflicto armado interno". En el caso de personas muertas o desaparecidas, pasan a ser consideradas víctimas el cónyuge, compañero o compañera permanente, parejas del mismo sexo y familiares en primer grado de consanguinidad. En ausencia de estos, pasan a serlo los familiares en segundo grado de consanguinidad ascendente. "De la misma forma, se consideran víctimas las personas que hayan sufrido un daño al intervenir para asistir a la víctima en peligro o para prevenir la victimización. La condición de víctima se adquiere con independencia de que se individualice, aprehenda, procese o condene al autor de la conducta punible y de la relación familiar que pueda existir entre el autor y la víctima".

\footnotetext{
${ }^{58}$ Todos los informes y los recursos audiovisuales están disponibles en la página web del Grupo de Memoria Histórica: http://www.memoriahistorica-cnrr.org.co/s-informes/

${ }^{59}$ En la jurisprudencia, la reparación alude a la reposición por parte de un criminal de una pérdida causada a una víctima. En contextos de justicia transicional (como el invocado por el Gobierno colombiano para dar legitimidad al proceso de desmovilización de las Autodefensas Unidas de Colombia en el año 2005), la reparación, junto con la verdad y la justicia, es uno de los objetivos fundamentales a ser alcanzados. En el caso específico de la Ley de justicia y paz, la reparación, en el artículo $8^{\circ}$, es entendida como "restitución, indemnización, rehabilitación, satisfacción y garantías de no repetición". En Ley de víctimas y restitución de tierras, el artículo 25 delimita lo que allí se llama reparación integral, así: "Las víctimas tienen derecho a ser reparadas de manera adecuada, diferenciada, transformadora y efectiva por el daño que han sufrido como consecuencia de las violaciones de que trata el artículo $3^{\circ}$ de la presente ley. La reparación comprende las medidas de restitución, indemnización, rehabilitación, satisfacción y garantías de no repetición, en sus dimensiones individual, colectiva, material, moral y simbólica. Cada una de estas medidas será implementada a favor de la víctima dependiendo de la vulneración en sus derechos y las características del hecho victimizante". (República de Colombia, 2011).
} 
La fecha a partir de la cual las personas son consideradas víctimas ha sido objeto de fuertes críticas y debates, en especial por miembros del partido de izquierda Polo Democrático Alternativo, así como por algunas asociaciones de víctimas, especialmente por las limitaciones que imponen a los procesos de restitución e indemnización ${ }^{60}$. En el proyecto inicial, se estipulaba como año de inicio 1991, lo cual evidencia que la presión de estos debates surtió algún efecto sobre la legislación, pero el Polo siguió considerándolo insuficiente, pues su propuesta era que el reconocimiento de la condición de víctima se diera a partir de 1980.

Más allá de esta definición jurídica, el Centro de Memoria Histórica en la cartilla Recordar y narrar el conflicto (2009) señala la importancia de tener en cuenta aspectos sociológicos, psicosociales e históricos a la hora de entender la noción de víctima. Uno de los principales llamados que hacía el Centro desde el año 2009 era tener presente que los hechos victimizantes se dan en veredas, pueblos o asentamientos poblacionales, lo cual trae como consecuencia una afectación colectiva, que viene a sumarse a la de los individuos que sufren de manera directa los daños físicos y materiales. Igualmente, hacen alusión al rechazo que genera el término mismo de víctima en personas que, aunque efectivamente han sido objeto de vejaciones y vulneración de sus derechos en el marco del conflicto armado, ven en este apelativo un riesgo de estigmatización como consecuencia de sus experiencias que tiende a acentuar "el sufrimiento, la impotencia y la pasividad, desconociendo la capacidad de las personas de afrontar los hechos y sus múltiples recursos para superar lo sucedido" (GMH, 2009, p. 45). A juicio del equipo del CMH, es importante resaltar otra cara de la moneda, aquella que hace de las víctimas sujetos de derechos y, en esa medida, se relaciona con una posición activa y de resistencia ante la afectación de los derechos fundamentales sufrida en el marco de sucesos violentos. Específicamente, se afirma

[... ] la consideración de "víctima" puede entenderse como el reconocimiento de un rol social de persona afectada en derechos fundamentales, lo que conlleva a construirla como sujeto de derechos. En este sentido la consideración de "víctima" sería una forma de resistencia activa con el fin de evitar la impunidad y la desmemoria, reconociendo y reconociéndose no solo en el sufrimiento sino también y especialmente en la condición de actores y actoras sociales en el intento de que se haga justicia, se reparen los daños ocasionados y se garantice la no repetición de las violaciones. En este contexto, la idea de víctima se constituiría en eje vertebrador y motor de cambio. Nombrarse víctima significaría entonces la posibilidad de reconocimiento y dignificación, ya que lo que no se nombra no existe o difícilmente se reconoce. Usado de esta manera, el concepto de víctima se convierte en herramienta de fortalecimiento evitando que el empleo del término conlleve a cristalizar una identidad anclada en el pasado y la pasividad. Es esta visión del concepto de víctima la que se desea rescatar en estos procesos y talleres de memoria histórica y la que los facilitadores y facilitadoras deberían transmitir a lo largo de la actividad (GMH, 2009).

Sin desconocer estos aspectos que explican y justifican el sentido de la categoría de víctima, se hace necesario señalar también los problemas que puede acarrear, no sólo porque desde el exterior pueda hacerse una estigmatización de las personas que en tal situación se encuentran sino porque ellas mismas pueden identificarse a tal punto con esa caracterización que terminen por no descorrerse de ella, bien por los beneficios simbólicos

\footnotetext{
${ }^{60}$ Para un panorama de las vicisitudes la Ley de víctimas desde el primer debate al que fue sometida hasta su aprobación, véase el artículo Cuatro años ocupó al Congreso una ley para las víctimas, de Rodrigo Urrego Bautista (2011). Disponible en: http://www.semana.com/nacion/articulo/cuatro-anos-ocupo-congreso-ley-paravictimas/240317-3
} 
y económicos que les representa, bien porque ese lugar se vuelve una base desde la cual posicionarse frente al mundo y los otros como testimonio vivo de una tragedia o como ejemplo de resistencia. Teniendo en cuenta estos riesgos y en aras de no perder de vista la complejidad de la noción de víctima, Blair (2008) sostiene que es preferible pasar de la idea de personas en condición de víctimas a la consideración de una situación de víctima, que matiza el componente ontológico e identitario que se esconde tras la definición de alguien como víctima. Acorde con esto, se plantea una caracterización antes que una clasificación de las mismas. Estas dos propuestas son argumentadas del siguiente modo:

\begin{abstract}
Mientras la primera, potencia la capacidad de agencia de las víctimas para transformar su situación y reconstruir sus proyectos de vida; la segunda muestra que el carácter de pérdida asociado a la muerte de los seres más próximos, que, efectivamente, las define es sólo un aspecto de las pérdidas que deben enfrentar en su situación. Se trata más bien de una "sumatoria de pérdidas" que amplía su situación de vulnerabilidad, pero, paradójicamente, les permite -en un acto de valentía y fortaleza que debe ser reivindicado-, construir en medio de esas pérdidas, diversas estrategias de sobrevivencia. El conocimiento de estas últimas es el que debe conducir u orientar cualquier trabajo político a nivel gubernamental u organizativo, hasta hacer posible el acceso a sus derechos. (Blair et. al., 2008, p. 229).
\end{abstract}

En los presupuestos del GMH está también el cuestionamiento al uso de una noción de víctima asociada a una identidad estática y a la pasividad. Sin embargo, suponemos que por consideraciones prácticas en términos de la posibilidad de restitución de derechos, no se renuncia a hablar de víctima, aunque sí se hace énfasis en su dignidad y en la posición activa que le reconocen a las personas que se encuentran bajo esta categoría.

Otro aspecto digno de atención en relación con este asunto es que, si bien en Colombia hay una construcción legal de las mismas que confirma los planteamientos de Vecchioli según los cuales "la condición de víctima, en definitiva, será el resultado de establecer una relación entre un sujeto y dicha categoría" (Vecchioli, 20013, p. 16), el GMH no toma como voces válidas para la producción de sus relatos únicamente las de las víctimas oficiales. Consecuente con su perspectiva de que un hecho violento no afecta únicamente a aquellos que son asesinados, torturados, heridos o desaparecidos y a su círculo más cercano, sino que hay efectos que recaen también sobre las comunidades que presencian las acciones 0 que escuchan desde sus casas disparos, explosiones o gritos de los torturados, se invita a dar testimonio a todos los miembros de la comunidad que tengan algo para contar. Así, sin que necesariamente pueda decirse que se está haciendo una extensión de la victimización, sí se le está dando un valor a la figura de los testigos, al mismo tiempo que se reconocen otro tipo de daños que corroen el tejido social. Aquí resulta pertinente traer de nuevo a colación lo que Catalina Uprimny plantea como crítica sobre el tipo de reparación que ofrece la existencia del $\mathrm{GMH}$, pues no está abriendo un espacio exclusivamente para las víctimas directas, sino que está contribuyendo al cumplimiento del deber de memoria del Estado y a la reparación de la sociedad en su conjunto, lo que, por momentos, parece dejar en un segundo plano la reparación específica de quienes han sufrido en carne propia algún tipo de victimización.

Sin embargo, son sus voces las privilegiadas -lo que no quiere decir que son las únicas tenidas en cuenta- y esto responde a una de las interpretaciones centrales del GMH y en la que se apuntala, además, un igualmente central propósito de sus informes: el presupuesto básico de que lo que ha sucedido en Colombia es una guerra prolongada que ha traído consigo una profunda degradación humanitaria $(\mathrm{GMH}, 2013$, p. 34) justifica que la reconstrucción de la memoria histórica que el Grupo ha llevado a cabo busque por todos los medios la dignificación de las víctimas, que suman millares (en especial entre la población 
civil) ante el desbordamiento innegable de la dinámica del conflicto armado. Esta apuesta ética es asumida, además, como un elemento fundamental para comprender el conflicto armado en su dimensión eminentemente política:

\begin{abstract}
El carácter invasivo de la violencia y su larga duración han actuado paradójicamente en detrimento del reconocimiento de las particularidades de sus actores y sus lógicas específicas, así como de sus víctimas. Su apremiante presencia ha llevado incluso a subestimar los problemas políticos y sociales que subyacen a su origen. Por eso a menudo la solución se piensa en términos simplistas del todo o nada, que se traducen o bien en la pretensión totalitaria de exterminar al adversario, o bien en la ilusión de acabar con la violencia sin cambiar nada en la sociedad. Una lectura del conflicto en clave política mantiene las puertas abiertas para su transformación y eventual superación, lo mismo que para reconocer, reparar y dignificar a las víctimas resultantes de la confrontación armada.
\end{abstract}

\title{
2.4 De Grupo a Centro de Memoria Histórica
}

Con la aprobación de la Ley de Víctimas, en mayo de 2011, el Grupo de Memoria Histórica desapareció tal como estaba concebido inicialmente, y sus funciones pasaron a ser desempeñadas por el Centro de Memoria Histórica, cuya estructura y funcionamiento están detallados en los artículos 146 a 148 de esa Ley, y regulados de manera más específica por los Decretos 244 y 4803, expedidos en junio y diciembre de 2011, respectivamente. Dentro de las implicaciones más importantes de esta transformación, encontramos la declaración de autonomía del Centro así como la misión de administrar el Programa de Derechos Humanos y Memoria Histórica que es también creado en un punto anterior de la misma Ley.

El Decreto 4803 del Ministerio de Justicia y del Derecho establece la estructura del CMH. En él, se trazan las funciones, alcances y límites de la labor del Centro, se pone de manifiesto su autonomía administrativa y financiera, se le asigna un patrimonio propio (indicando también qué otras fuentes de financiamiento le son autorizadas, por ejemplo, a través de la cooperación privada o internacional) y se deja claro, desde las consideraciones iniciales, que "de conformidad con lo previsto en el artículo 2 del decreto Ley 2244 de 2011, el Centro de Memoria Histórica no podrá asumir funciones jurisdiccionales, ni interferir en procesos en curso ante fiscales, jueces o autoridades disciplinarias, teniendo en cuenta su naturaleza no judicial y no sancionatoria". Los resultados de su labor investigativa, que incluye trabajo de archivo y acopio de testimonios en las distintas regiones del país, no constituyen material probatorio ni son tenidos en cuenta en los procesos judiciales adelantados en contra de los distintos actores del conflicto que han sido capturados o que se han acogido voluntariamente a procesos de negociación o desmovilización (tanto guerrilleros como paramilitares). Por si quedara alguna duda en este sentido, otra de las consideraciones que se toman en cuenta para la expedición del Decreto 4803, dice: "Que el Decreto Ley 2244 del 28 de junio de 2011, adiciona funciones al Centro de Memoria Histórica relacionadas con el mecanismo no judicial de contribución a la verdad y la memoria histórica". (Las negrillas son nuestras).

En la sección de recomendaciones de uno de sus informes, el Centro (para ese entonces Grupo de Memoria Histórica) describe en los siguientes términos el lugar de su labor en el abordaje multifactorial del conflicto armado:

El Grupo de Memoria Histórica de la CNRR no tiene funciones ejecutivas, no lleva a cabo tareas de reparación y no tiene competencias judiciales, pues la Ley no lo previó así. Sin embargo, el informe que aquí se presenta junto con las recomendaciones son un eslabón de una cadena de acciones que debe comprometer a múltiples organismos 
estatales, así como a las más diversas organizaciones y expresiones de la sociedad colombiana. El informe es un lugar de encuentro entre los derechos de las víctimas, y las responsabilidades y los deberes del Estado y la sociedad (Informe Remedios y Segovia, p. 330).

Su objeto es "la recepción, recuperación, conservación, compilación y análisis de todo el material documental, testimonios orales y por cualquier otro medio, relativo a las violaciones ocurridas con ocasión del conflicto armado interno colombiano, a través de la realización de las investigaciones, actividades museísticas, pedagógicas y otras relacionadas que contribuyan a establecer y esclarecer las causas de tales fenómenos, conocer la verdad y contribuir a evitar en el futuro la repetición de los hechos" (República de ColombiaMinisterio de Justicia y del Derecho, 2011).

Esquemáticamente, su objeto puede dividirse en tres aspectos que especifican qué ha de hacer el $\mathrm{CMH}$, la forma o cómo ha de encarar esa misión y los propósitos que la guían, esto es, el por qué. Siguiendo esta lógica, lo que tienen que hacer es recibir, recuperar, conservar, compilar y analizar documentos y testimonios (orales o por cualquier otro medio) sobre violaciones ocurridas con ocasión del conflicto armado interno colombiano. El acopio de toda esta información se llevará a cabo mediante actividades investigativas, museísticas y pedagógicas, con el propósito de contribuir a establecer y esclarecer las causas del conflicto; conocer la verdad y contribuir a evitar en el futuro la repetición de los hechos.

Mientras que los dos primeros puntos constituyen indicaciones precisas acerca de qué tipo de información se espera que recupere el $\mathrm{CMH}$ y mediante qué estrategias, el último punto se torna ambicioso e inespecífico, pues no queda claro qué se entiende por "verdad" ni mediante qué estrategias un grupo sin funciones ejecutivas, judiciales ni de reparación, puede contribuir a la no repetición de hechos complejos y persistentes a lo largo de la historia colombiana, aunque sí es ponderable su aporte al esclarecimiento de las causas del conflicto y al conocimiento de una parte de la verdad acerca de los hechos asociados al conflicto armado.

En cuanto a las funciones atribuidas al Centro, consideramos pertinente clasificarlas en tres grandes grupos: 1) aquellas que le conciernen directamente y se refieren a acciones concretas, con resultados palpables; 2) aquellas indirectas y de apoyo a la labor de otros organismos gubernamentales y no gubernamentales; y 3) las que tienen un carácter normativo y ético, relacionados más con los efectos deseables derivados de la labor del grupo, pero que son difícilmente medibles y observables, en especial en el corto plazo: 


\section{Clasificación de las funciones del centro de memoria histórica según el decreto 4803 de 2011}

\begin{tabular}{|c|c|c|}
\hline Funciones directas y concretas & Funciones indirectas y de apoyo & Funciones Éticas \\
\hline $\begin{array}{l}\text { Diseñar, crear y administrar un } \\
\text { Museo de la Memoria, } \\
\text { destinado a lograr el } \\
\text { fortalecimiento de la memoria } \\
\text { colectiva acerca de los hechos } \\
\text { desarrollados en la historia } \\
\text { reciente de la violencia en } \\
\text { Colombia, procurando conjugar } \\
\text { esfuerzos del sector privado, la } \\
\text { sociedad civil, la cooperación } \\
\text { internacional y el Estado }\end{array}$ & $\begin{array}{l}\text { Apoyar, en el marco de sus } \\
\text { competencias, los esfuerzos } \\
\text { públicos y privados para la } \\
\text { adecuada atención integral y } \\
\text { garantía de los derechos } \\
\text { humanos y de la aplicación del } \\
\text { Derecho Internacional } \\
\text { Humanitario que les asisten a } \\
\text { las víctimas }\end{array}$ & $\begin{array}{l}\text { Contribuir, con las demás } \\
\text { entidades públicas y privadas } \\
\text { con responsabilidades en la } \\
\text { materia, a impulsar la iniciativa } \\
\text { de articular una red } \\
\text { latinoamericana de Estados que } \\
\text { se comprometa a proteger y } \\
\text { divulgar las memorias de los } \\
\text { conflictos y regímenes } \\
\text { autoritarios, como también } \\
\text { diseñar estrategias pedagógicas } \\
\text { y de comunicación social con el } \\
\text { propósito de contribuir a las } \\
\text { garantías de no repetición. }\end{array}$ \\
\hline $\begin{array}{l}\text { Diseñar, crear y administrar el } \\
\text { Programa de Derechos } \\
\text { Humanos y Memoria Histórica } \\
\text { de que trata el artículo } 144 \text { de la } \\
\text { ley } 1448 \text { de } 2011 .\end{array}$ & $\begin{array}{l}\text { Servir como plataforma de } \\
\text { apoyo, gestión, intercambio y } \\
\text { difusión de iniciativas locales, } \\
\text { regionales y nacionales en los } \\
\text { temas de memoria histórica, } \\
\text { promoviendo la participación de } \\
\text { las víctimas, con enfoque } \\
\text { diferencial }\end{array}$ & \\
\hline $\begin{array}{l}\text { Oficiar como centro de acopio, } \\
\text { producción y difusión de } \\
\text { memorias y esclarecimiento } \\
\text { histórico de las violaciones } \\
\text { ocurridas en el marco del } \\
\text { conflicto armado interno. }\end{array}$ & $\begin{array}{l}\text { Oficiar como espacio de apoyo a } \\
\text { las entidades públicas y privadas } \\
\text { en el marco de las iniciativas } \\
\text { ciudadanas en temas de } \\
\text { memoria histórica. }\end{array}$ & $\begin{array}{l}\text { Desarrollar investigaciones, } \\
\text { eventos, seminarios, foros y } \\
\text { demás formas de estudio y } \\
\text { análisis que contribuyan a la } \\
\text { construcción de la verdad, la } \\
\text { reparación y la convivencia } \\
\text { ciudadana. }\end{array}$ \\
\hline
\end{tabular}




\begin{tabular}{|c|c|c|}
\hline $\begin{array}{l}\text { Proveer insumos, en el marco de } \\
\text { sus competencias, a las } \\
\text { entidades encargadas de } \\
\text { adelantar procesos de } \\
\text { reparación que impulsa el } \\
\text { Estado y de formulación de las } \\
\text { políticas públicas en la materia }\end{array}$ & $\begin{array}{l}\text { Promover y motivar, a nivel } \\
\text { territorial, la participación de las } \\
\text { víctimas, las organizaciones } \\
\text { sociales y la academia, en el } \\
\text { diseño, desarrollo y difusión de } \\
\text { iniciativas de reconstrucción de } \\
\text { memoria histórica, con el apoyo } \\
\text { de las entidades territoriales, a } \\
\text { través de sus instituciones y } \\
\text { programas }\end{array}$ & $\begin{array}{l}\text { Velar por la difusión amplia y } \\
\text { masiva de los resultados de las } \\
\text { investigaciones, buscando que } \\
\text { los diferentes enfoques, } \\
\text { perspectivas y conclusiones } \\
\text { sean conocidos por la sociedad } \\
\text { en un ambiente de respeto y } \\
\text { pluralidad por la búsqueda de la } \\
\text { verdad. }\end{array}$ \\
\hline $\begin{array}{l}\text { Desarrollar investigaciones, } \\
\text { eventos, seminarios, foros y } \\
\text { demás formas de estudio y } \\
\text { análisis que contribuyan a la } \\
\text { construcción de la verdad, la } \\
\text { reparación y la convivencia } \\
\text { ciudadana. }\end{array}$ & & $\begin{array}{l}\text { Garantizar el derecho de acceso } \\
\text { a la información respetando las } \\
\text { reservas de ley y las } \\
\text { salvaguardas propias del } \\
\text { proceso de acopio y } \\
\text { preservación de las memorias }\end{array}$ \\
\hline $\begin{array}{l}\text { Implementar estrategias } \\
\text { pedagógicas y comunicativas, } \\
\text { con enfoque diferencial, para la } \\
\text { difusión y apropiación, por parte } \\
\text { de diversos públicos, de los } \\
\text { procesos y los resultados de su } \\
\text { gestión, así como de las } \\
\text { iniciativas de memoria locales y } \\
\text { regionales descentralizadas }\end{array}$ & & \\
\hline $\begin{array}{l}\text { Recolectar, clasificar, acopiar, } \\
\text { sistematizar, analizar y } \\
\text { preservar la información que } \\
\text { surja de los Acuerdos de } \\
\text { Contribución a la Verdad } \\
\text { Histórica y la Reparación de que } \\
\text { trata la Ley } 1424 \text { de } 2010\end{array}$ & & \\
\hline
\end{tabular}




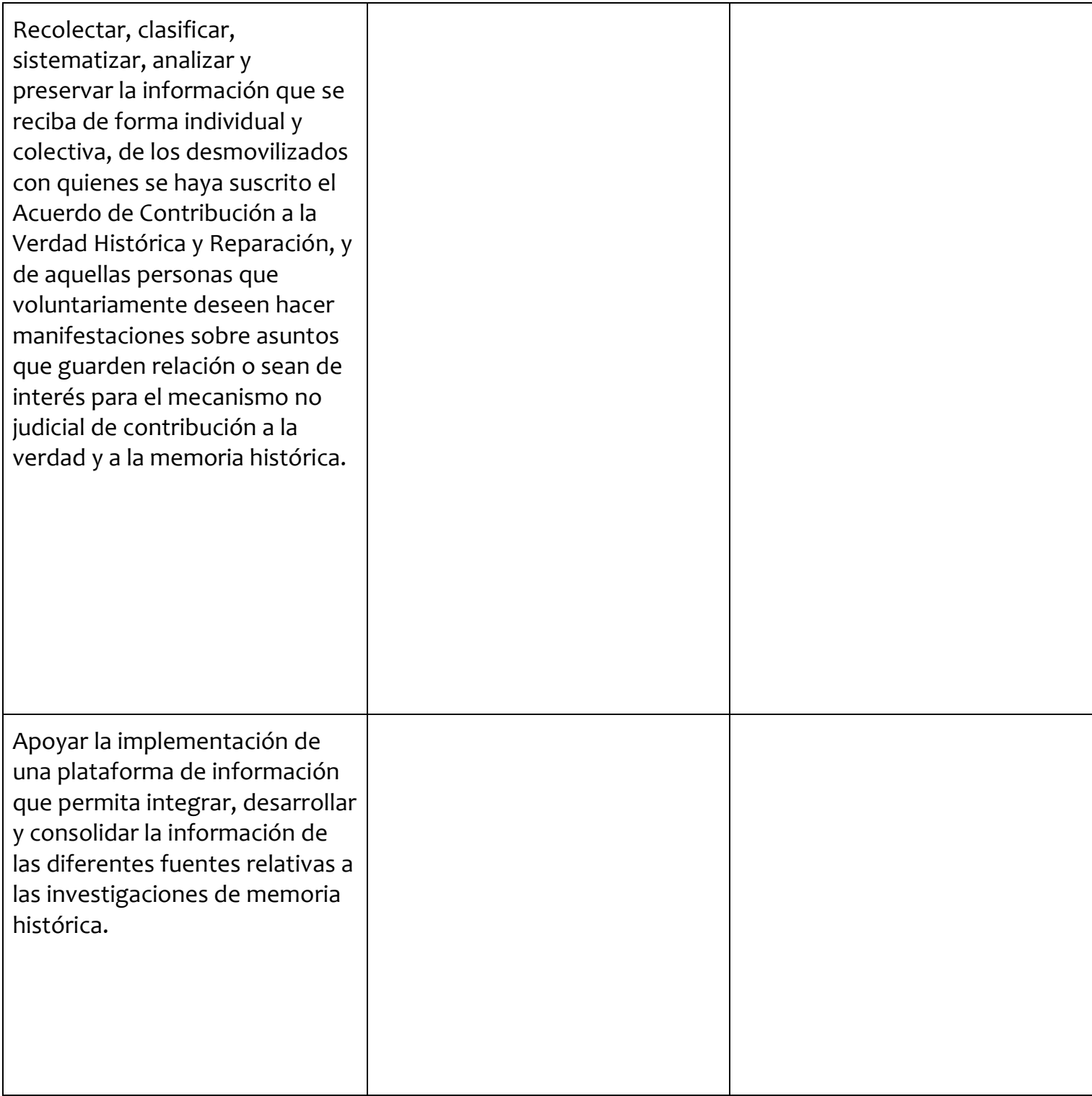

Hecha la presentación del Grupo y el Centro de Memoria Histórica, encontramos varios aspectos que vale la pena resaltar para avanzar en la problematización propuesta entre los conceptos de memoria nacional y memoria oficial. Un primer aspecto que resulta llamativo es que en la presentación de su trabajo, el Grupo habla explícitamente de memorias -en plural-, con una opción preferencial por las víctimas y por aquellas minorías que han sido suprimidas o silenciadas. Se trata de una unión, en lo oficial, de las memorias que Pollak parecía oponer, un privilegio de las memorias subterráneas para hacer la construcción de la memoria nacional acerca del conflicto. En Memoria, olvido, silencio, Pollak hace referencia a procesos de este tipo, momentos en los que las memorias subterráneas o marginales, que se han mantenido por fuera del discurso oficial pero se han transmitido oralmente o por medios menos visibles, cobran relevancia, les llega su "hora de la verdad" (Pollak, 2006, p. 20).

En el caso colombiano, no podría decirse que es esto lo que ha sucedido. Si bien es cierto que la creación del Grupo de Memoria Histórica es un paso importante en el reconocimiento de la responsabilidad política del Estado como garante de las memorias, también lo es que su trabajo supone numerosas dificultades, en parte porque el tiempo del 
conflicto no ha pasado y, en esa medida, hay todavía temor en la población para expresar sus versiones de los hechos; en parte también porque las fuerzas armadas y civiles estatales (esto es, ejército y policía) estuvieron, en algunos de los casos estudiados, del lado de los perpetradores y, finalmente, porque las políticas de difusión son escasas y no ha existido hasta ahora una voluntad de dar a conocer masivamente los resultados de las investigaciones realizadas, como ocurrió en Argentina con el emblemático libro del Nunca más (Conadep, 1984) o la transmisión de programas televisivos donde se entrevistaba a quienes habían padecido, visto e incluso perpetrado las acciones propias del terrorismo de estado. En el país austral, pocos meses después del retorno a la democracia, se dio gran visibilidad a los testimonios de los sobrevivientes de los centros clandestinos de detención e incluso, como resalta Claudia Feld (2002), se llegó a una especie de "show del horror" que mediatizó las declaraciones tanto de las víctimas como de los victimarios lo cual, si bien puede ser cuestionado desde muchos puntos de vista, permitió una visibilización de los hechos que hacían imposible su negación por parte de la sociedad civil.

Lo que se pretende con esta comparación no es emular el tratamiento mediático que se le dio a estos acontecimientos en Argentina, sino señalar una diferencia radical entre los procesos de memoria emprendidos en ambos países, reflejo quizá de la también radical diferencia entre los acontecimientos violentos que se busca recordar en cada caso. En el caso colombiano, con la publicación del ¡Basta ya! parece haberse iniciado un giro en las estrategias de difusión. Sin que se haya llegado a la masividad de la circulación que tuvo el Nunca Más en Argentina, este informe ha sido el más reproducido y ampliamente distribuido de todos. Se ha entregado de manera gratuita en eventos, ha llegado a instituciones educativas públicas como material de consulta y se puso a disposición del público en general para ser reclamado en la sede del Centro de Memoria Histórica en Bogotá. A seis meses de su publicación, se diseñó una revista que circuló en la edición dominical de algunos de los principales diarios del país, en la que se presentaban las distintas áreas del trabajo del $\mathrm{GMH}$, había entrevistas a víctimas e investigadores y se registraban, a grandes, rasgos, los principales ejes temáticos del ¡Basta ya! cuya portada cerraba la edición de la revista, llamada Conmemora. En conversaciones con Mauricio Builes, comunicador del Grupo, se conoció que la idea es darle continuidad a la revista, elaborar una versión resumida del informe general, de más fácil lectura para los lectores no especializados, así como la emisión de un programa de radio en el podrán -literalmenteescucharse las voces de las víctimas acompañadas de análisis que contextualicen los testimonios. Esta nueva fase de difusión apenas comienza y tendría que esperarse algún tiempo antes de indagar por sus alcances y sus efectos.

\subsection{El jardín de las versiones que se bifurcan}

Después del recorrido realizado hasta aquí, surgen varias preguntas: ¿para qué se llevan a cabo los ejercicios de memoria histórica? ¿Cuál es el sentido de los informes, los documentales y otras producciones? ¿Cuál su destino? Nos encontramos ante un Estado cuyo presidente, en el momento de la conformación del Grupo negaba la existencia de un conflicto armado en el país ${ }^{61}$ y, sin embargo, creaba una Comisión Nacional de Reparación y Reconciliación cuyas funciones inclúan la recuperación de la memoria, eso sí, de aquella relacionada con las "razones para el surgimiento y evolución de los grupos armados

\footnotetext{
${ }^{61}$ Recuérdese que Álvaro Uribe Vélez, presidente de Colombia entre 2002 y 2010, declaró en distintos encuentros internacionales, a principios del año 2005, que en el país no hay conflicto armado sino "amenaza terrorista". Para una cronología y un análisis crítico de tal afirmación, véase el artículo "Sí hay guerra, señor presidente", de la Revista Semana. [En línea] Disponible en: http://www.semana.com/portada/guerra-senorpresidente/84650-3.aspx
} 
ilegales" (República de Colombia, 2005, artículo 51, punto 51.2). En todo el texto de la Ley no aparece la noción de conflicto armado, ni tampoco la referencia a las víctimas del Estado. Sin embargo, el Grupo de Memoria Histórica, encargado real de los procesos de reconstrucción, afirma con todas las letras y en el primer párrafo de su presentación en la página web que su objetivo es elaborar y divulgar una narrativa sobre el conflicto armado en Colombia, a continuación de lo cual enuncia lo relativo a la identificación de las razones para el surgimiento y la evolución de los grupos armados ilegales, pero dándole otra dimensión, en tanto los reconoce como parte de un conflicto que, desde la jefatura de gobierno, se pretendía negar.

¿De qué da cuenta esta inconsistencia (por llamarla de alguna manera) en el manejo del lenguaje en distintos ámbitos de una misma oficialidad? Más allá de que pueda tratarse de una enmienda en el texto que se dio con el cambio de gobierno ${ }^{62}$, el hecho es que desde los primeros informes, en los años 2008 y $2009^{63}$, el Grupo habla explícitamente de conflicto armado, lo que evidencia una toma de distancia contundente del discurso que, inicialmente, se buscaba promover desde el gobierno presidido por Uribe Vélez. Esto da cuenta de que las disputas existen también dentro del espectro oficial y no son asunto solamente de grupos marginales o subterráneos.

Vemos aquí una clara expresión del Estado en plural del que habla Soprano (2007, p. 19), en el que se "identifica una diversidad de instituciones, actores, lógicas y prácticas sociales", con distintos propósitos y tendencias dentro de un mismo aparato estatal. Aplicando las ideas de este autor al caso que nos ocupa, podemos afirmar que

\begin{abstract}
[... ] una mirada más preocupada por reconocer matices en los procesos históricos, revelaría que el Estado también puede comprenderse como una institución más bien heterodoxa y bastante menos eficaz en su pretensión de ejercer el monopolio legítimo de la violencia física y simbólica sobre una población inscripta en un territorio. [...] Esta nueva mirada, además, nos permitiría reconocer que las elites que controlan las agencias estatales y sus dispositivos de gobernación, pueden orientar su acción de acuerdo a sentidos plurales, definidos en interlocución con diversos actores localizados dentro y fuera del ámbito estatal.
\end{abstract}

Quizá vale la pena también mencionar, para no perderla de vista, la diferencia entre Estado y gobierno, teniendo en cuenta que el primero es más amplio y, si se quiere, estable, mientras los gobiernos varían según lapsos establecidos por las leyes de cada país para las instituciones que lo constituyen cada uno de sus poderes (ejecutivo, legislativo y judicial).

Desde esta perspectiva, aparece un nuevo interrogante: ¿el hecho de que el Grupo de Memoria Histórica surja por iniciativa estatal hace de él un portador del discurso oficial? Teniendo en cuenta su apuesta metodológica, que implica, según afirman, las distintas verdades y memorias de la violencia, con un enfoque diferenciado y una opción preferencial por las voces de las víctimas que han sido suprimidas o silenciadas, ¿sería posible hablar de una estatización de la memoria? Para Da Silva Catela, tal estatización se refiere al "papel central que ocupa el Estado como agente de memoria y su pretensión de generar una

\footnotetext{
${ }^{62}$ El presidente Juan Manuel Santos, quien asumió el cargo en agosto de 2010 ha sido partidario de reconocer el conflicto armado colombiano. La definición de la Ley de Víctimas que hemos venido citando así lo demuestra: Ley 1448 del 10 junio de 2011, "por la cual se dictan medidas de atención, asistencia y reparación integral a las víctimas del conflicto armado interno y se dictan otras disposiciones". (República de Colombia, 2011).

${ }^{63}$ Los informes correspondientes a esos años se titulan, respectivamente: Trujillo, una tragedia que no cesa (2008) y El salado: esa guerra no era nuestra (2009).
} 
política centralizada de memoria, negando implícitamente la pluralidad de memorias que circulan y son defendidas por diversos grupos e instituciones" (Da Silva Catela, 2011, p. 8). Tal descripción, que es muy similar a la de Pollak y que hace hincapié en la negación de la pluralidad que realizarían las memorias estatales, no parece coincidir con lo que está siendo desarrollado por el organismo estatal que, en Colombia, está encargado de la reconstrucción de memorias sobre el conflicto y que, explícita y reiteradamente, afirma su reconocimiento de la pluralidad de memorias como fundamento para elaborar sus propios relatos, aspecto estrechamente relacionado con el antes citado parágrafo incluido en la Ley de víctimas que prohíbe la elaboración de una verdad oficial. Las producciones del GMH ponen de manifiesto que esta disposición no es un mero discurso vacío: la investigación inaugural del GMH consistió en la elaboración de un repertorio de las iniciativas de memoria que estaban siendo propiciadas por víctimas y organizaciones civiles a lo largo y ancho del territorio nacional ${ }^{64}$. El libro Memorias en tiempo de guerra, una de las primeras publicaciones del $\mathrm{GMH}$, recoge y sistematiza estas iniciativas con base en sus principales características. Allí establecen una tipología de iniciativas según cuatro categorías (Memorias en el espacio, la tierra y el territorio; Memorias colectivas que se construyen y se preservan como historia; Memorias que exaltan las identidades borradas por la guerra y, por último, Memorias ancladas en el cuerpo que trabajan la subjetividad), dentro de cada una de las cuales identifican a su vez distintos subtipos de iniciativas. No nos detendremos aquí en un análisis detallado de las mismas, pues el objetivo de la tesis es hacer un análisis del discurso oficial sobre el conflicto armado, y las acciones recopiladas en ese informe no tienen ese carácter. Sin embargo, su inclusión en este primer libro da cuenta de un reconocimiento que hace el $\mathrm{GMH}$ de las mismas a partir del cual estructura y organiza su propia reconstrucción de las memorias del conflicto. Su organización y difusión, así como la inclusión de muchas de ellas en sus informes, permite afirmar que no se trata de una intención irrealizada. Eso no quiere decir, por supuesto, que no haya críticas o sesgos en torno a las selecciones, pero la posición simbólica del Estado es otra que la señalada por Da Silva Catela. En el quinto capítulo del ¡Basta ya!, dedicado específicamente a las memorias, declaran:

Esta tarea de reconstrucción de memoria histórica se emprende reconociendo la heterogeneidad de los relatos y de sus significados, que alude a la diversidad de sujetos y grupos que hacen memoria desde experiencias y contextos diferentes. Esto supone rechazar cualquier intento por condensar estas memorias bajo una sola lógica narrativa o marco explicativo, o atribuirles un sentido cerrado, fijo e inmutable. En este sentido, si bien el capítulo ofrece ciertas generalizaciones sobre las memorias emblemáticas, los énfasis narrativos y los sentidos, no los presenta como parte de lo que algunos denominan memoria colectiva que se comparte como nación e incluso como región o como comunidad de sufrimiento. No obstante, desde la pluralidad de voces que conforman la memoria histórica, este ejercicio de reconocimiento de las memorias de las víctimas constituye un patrimonio público, cuya impronta en la sociedad colombiana aporta a la consolidación del compromiso con la no repetición. (GMH, 2013, pp. 330-331).

Si lo que suele estar en la base de las críticas y sospechas de que sea el Estado el principal promotor de las memorias es que habrás voces que sean silenciadas o excluidas especialmente aquellas que atentan contra la imagen misma del Estado-, es palpable en la producción del GMH una voluntad por incorporar la mayor cantidad de voces posibles, pues

\footnotetext{
${ }^{64}$ El mapa de iniciativas de memoria en el país fue sistematizado por el GMH y puede ser consultado en la siguiente dirección electrónica: http://www.centrodememoriahistorica.gov.co/index.php/iniciativas-dememoria/iniciativas-de-memoria
} 
si bien son insistentes en la reivindicación de los testimonios de víctimas, testigos y sobrevivientes, estos son permanentemente contrastados con las versiones de los medios de comunicación, los relatos de miembros de organizaciones gubernamentales y no gubernamentales que tuvieron relación con los hechos en cuestión y los legajos y sentencias judiciales derivados del caso. Así, la trilogía de hechos, contextos y actores como dimensiones que guían las indagaciones del Grupo se mantiene en pie y opera como brújula que busca mantener un cierto equilibrio de la narración de tal modo que sus elaboraciones no caigan en la simpleza de una historia de manual.

Con el cambio de estructura y la ampliación de funciones derivadas de la creación del Centro Nacional de Memoria Histórica, la pluralidad de memorias que serán tenidas en cuenta se amplía hasta abarcar también las voces de los victimarios que, aunque presentes en algunos de los informes de casos emblemáticos ${ }^{65}$, pasarán a ser ahora el acervo fundamental de otro de los capítulos de la reconstrucción de la memoria histórica que se ha emprendido en Colombia: los acuerdos por la verdad, que buscan que miembros de los grupos armados ilegales que no hayan participado directamente en crímenes de lesa humanidad, pero que tengan conocimiento de los mismos por parte del bloque o frente armado del que hacían parte, narren lo que saben con el fin de aportar al esclarecimiento de los hechos, así como al derecho a la verdad de los familiares y allegados de las víctimas.

Otro aspecto que también encontramos relacionado con la pluralidad, y que no toca ya sólo con las voces tenidas en cuenta para la construcción de los informes, sino con los encargados de dicha construcción es que la conformación del Grupo, por el origen y filiaciones de sus investigadores, lleva a pensar que se trata de un equipo cuya mirada se sabía crítica de antemano, lo que torna por lo menos llamativo el hecho de que hayan sido designados para cumplir esta misión durante un gobierno con las características que hemos esbozado. Como ya vimos, Gonzalo Sánchez, su director fue también el presidente de la llamada comisión de "violentólogos" en 1987 y uno de los académicos más conocedores del tema y más prestigiosos del país. Su filiación política es afín con las ideas socialistas (Torres, 2004) y su amplia trayectoria en el estudio de la violencia política en el país ha sido reconocida por la agudeza de sus interpretaciones y su interés por las voces de las víctimas. Dada su trayectoria, es evidente que se trata de una persona idónea para dirigir una empresa de la magnitud de la confiada al $\mathrm{GMH}$, pero no por esto es menos sorprendente que, desde un gobierno marcadamente alineado a la derecha, se le encargue semejante misión a alguien que, sin ocultar su rechazo a la lucha armada, se ubica en una tendencia ideológica contraria.

Según se desprende del estudio de Jaramillo (2011), la constitución del Grupo/Centro de Memoria Histórica estuvo antecedida por una serie de discusiones no tanto acerca de sus integrantes específicos sino de la metodología que adoptarían y el nivel de control que el gobierno tendría sobre sus conclusiones. Como se mostró, hubo quienes abogaban por una revisión previa de todo lo que iba a ser publicado, pero al final primó una perspectiva técnica que le apostaba a unos criterios básicos de trabajo pero respetando la autonomía del Grupo para presentar sus hallazgos y conclusiones. Dicha autonomía fue corroborada y ampliada por la Ley de Víctimas, en la que se le asignaron al Centro nuevas tareas relacionadas con los derechos humanos, la administración de iniciativas museísticas y la recepción y organización de los testimonios de paramilitares desmovilizados para continuar

\footnotetext{
${ }^{65}$ En varios de los informes se tomaron algunas de sus declaraciones ante los estrados judiciales para corroborar lo dicho por testigos y sobrevivientes o para poner en evidencia la frialdad, el cinismo o, también, la voluntad de colaboración con el esclarecimiento de los hechos de algunos perpetradores.
} 
avanzando en la labor de esclarecimiento de los acontecimientos ligados al conflicto armado. Nos queda la impresión de que con la entrega del informe ¡Basta ya! se cierra finalmente el capítulo del Grupo de Memoria Histórica, habiéndose completado la tarea inicialmente encomendada. Entre el 2011 y el 2013 se dio un proceso de transición en el que se mantuvieron las líneas de trabajo que ya venían marchando, pero se hizo necesario plantear unas nuevas y estructurarlas. Entre las más importantes está la apertura de los Acuerdos de la verdad ${ }^{66}$ y la planeación de un Museo Nacional de la Memoria, iniciativas sobre las que será interesante mantener puesta la atención para hacer un seguimiento de las políticas de la memoria en Colombia.

La fase del GMH dejó informes escritos, documentales, discos, exposiciones artísticas. Su metodología implicó además procesos constructivos, de catarsis y elaboración con las víctimas, lo cual es ya un primer efecto importante y localizado de su trabajo. Otro, igualmente localizado, es la socialización de los resultados y la entrega de los informes y demás producciones relacionadas con cada caso a las comunidades donde se realizaron las investigaciones. Puede apreciarse en estos procesos una elaboración fuerte de las memorias locales, pero... iy la memoria nacional, aquella en la que puedan reconocerse las repeticiones, las relaciones, los puntos de confluencia de una realidad que atraviesa a Colombia como país? La construcción de la misma comenzó con el informe ¡Basta ya!, el cual procura ser un ejercicio más abarcativo, que posibilita una visión de conjunto del conflicto colombiano, aunque sin desconocer su complejidad y especificidades locales. La publicación de este informe, a diferencia de los regionales, suscitó un amplio interés en los medios de comunicación nacional e internacional, y durante la semana en que fue entregado oficialmente y algunas de las posteriores, se mantuvo en la agenda de las noticias escritas y audiovisuales, al tiempo que fue objeto de debate en programas radiales y televisivos, y distintos columnistas de opinión y análisis político dedicaron sus espacios a comentar el contenido y hallazgos del mismo.

El gran interrogante ahora tiene que ver con lo que sucederá de aquí en adelante con la copiosa producción elaborada por el GMH. ¿Se establecerá alguna política de Estado para la difusión y estudio de algunos de los informes en colegios y universidades, como lo ha recomendado el propio $\mathrm{GMH}$ ? ¿El cubrimiento mediático recibido por el ¡Basta ya! despertará en los ciudadanos una curiosidad que los lleve a aproximarse a su lectura y, en general, a indagar por lo que ha hecho el GMH? ¿Surtirán efecto las interpelaciones, los llamados a la reflexión, la búsqueda por romper con el ciclo de indiferencia a partir del uso de los testimonios de las víctimas? ¿O la mayoría de la gente continuará actuando como si en Colombia no pasara nada?

Algo no tiene que estar oculto para ser invisible. Bien ilustrado le quedó a Edgar Allan Poe, en La carta robada que, a veces, la mejor manera de desviar la atención sobre algo es dejándolo al alcance de la mano. Todos los informes que ha producido el Grupo son públicos, están disponibles en su página web y pueden descargarse gratuitamente. Del

\footnotetext{
${ }^{66}$ La Dirección de Acuerdos de la Verdad (DAV) tiene como función "recibir, clasificar, sistematizar, analizar y preservar los testimonios de aproximadamente 15 mil desmovilizados de las AUC que firmaron los acuerdos de la Verdad con el Gobierno Nacional". Para hacer partes de estos acuerdos, establecidos en el 2010, los ex paramilitares debían cumplir con los requisitos de no estar comprometidos en delitos graves y haber seguido el proceso de reintegración a la vida civil sin reincidir en la delincuencia. "La DAV es responsable de certificar la contribución, efectiva o no a la verdad, de estos desmovilizados, así como de elaborar informes que serán entregados a la sociedad para ayudar al entendimiento de las causas, circunstancias y consecuencias de las situaciones más graves de violencia que han tenido lugar durante el conflicto armado colombiano". Tomado de: http://www.centrodememoriahistorica.gov.co/index.php/direcciones/acuerdos-de-la-verdad
} 
mismo modo, es posible acceder a los documentales, los discos, las fotografías de todos los eventos que han realizado. $\mathrm{Y}$, para quienes prefieren los libros tradicionales, hay una versión impresa de cada texto, disponible en librerías de todo el país y en la sede del $\mathrm{CMH}$, en Bogotá. Adicional a esto, anualmente se realiza en la capital y las principales ciudades del país una Semana por la Memoria, en la que se presentan las producciones que han visto la luz en el último año de trabajo, se realizan exposiciones y seminarios en las que participan académicos, organizaciones de víctimas, miembros del gobierno nacional y otros tantos de gobiernos extranjeros, así como agencias de derechos humanos. Todo abierto al público, sí, pero en unas pocas ciudades y con la participación privilegiada de aquellos para los que la memoria es de por sí un asunto de interés, bien porque son protagonistas de los informes presentados o porque se han dedicado al estudio del conflicto armado. No puede decirse que se esconde nada. Sin embargo, hay claras limitaciones en la difusión de las narrativas sobre el conflicto y, lo que es más inquietante, una proliferación de relatos fragmentarios que, recién hasta ahora, han buscado ser concatenados para trazar los elementos de lo que pudiera ser una memoria nacional Si bien esto es deseable en términos de contar con un relato unificador con el que la sociedad civil en su conjunto pudiera identificarse, es necesario reconocer que la tensión entre lo local y lo nacional es bastante compleja en Colombia, un país vasto en extensión, con marcadas diferencias geográficas y culturales entre regiones que le dan al conflicto matices específicos en cada zona y dificultan la realización de un análisis global que, siendo abarcativo del panorama nacional, no desconozca las particularidades de los procesos regionales. El carácter de las iniciativas estatales para la comprensión y abordaje del conflicto que hemos examinado en este capítulo evidencia que se han intentado ambas vías, si bien ha tendido a privilegiarse la mirada local: las comisiones de 1958, 1992 y concentraron su análisis en las regiones, en aras de explicar y caracterizar el conflicto desde sus raíces y de realizar propuestas más concretas y acordes con esos hallazgos. Por su parte, el Grupo/Centro de Memoria Histórica, si bien comenzó su trabajo siguiendo esta misma línea, lo hizo teniendo presente que se trataba de un proceso previo a la construcción de un relato nacional y por eso estructuró sus investigaciones alrededor de casos emblemáticos en los que pueden identificarse las particularidades regionales tanto como las características en común que presenta el conflicto armado en el país.

En cuanto a la transmisión de las memorias que se han reconstruido con las comunidades desde el año 2007, el Centro de Memoria Histórica ha venido realizando cada vez más actividades de difusión y, además de la descentralización de la Semana por la Memoria -que suele adelantarse cada año entre octubre y noviembre-, se han implementado estrategias masivas de comunicación a través del uso de redes sociales como Facebook y Twitter, y se ha incrementado la participación en eventos culturales de gran asistencia por medio de conferencias y conversatorios sobre los retos y los hallazgos del grupo. Por ejemplo, el $2 \mathrm{de}$ mayo de 2012, día de la conmemoración de los diez años de la masacre de Bojayá (en la que murieron aproximadamente 80 personas, 48 de ellas menores de edad) el (entro realizó en la red social Twitter una transmisión pormenorizada de los enfrentamientos entre guerrilleros y paramilitares que desembocaron en la masacre, con base en los relatos que aparecen en el informe Bojayá, la guerra sin límites $(\mathrm{GMH}, 2010)$. Dicha transmisión recreaba el minuto a minuto de la toma como si estuviese aconteciendo ese día y cada fragmento de la narración culminaba con la etiqueta “\#Bojayá10años", de tal modo que los lectores supieran que estaban ante un ejercicio de memoria que buscaba dar a conocer la magnitud de una masacre emblemática del conflicto colombiano. Igualmente, se promovió la campaña "Bojayá está en mi memoria", que consistía en que tanto personajes públicos como ciudadanos de a pie, grabaran un video corto en el que contaran qué recordaban de la masacre, el cual debía concluir con la frase que daba nombre a la campaña. Estos videos 
circularon en Facebook y en Twitter durante el mes de mayo de 2012 y pueden verse de manera permanente en la página web del Centro de Memoria Histórica.

Otra actividad importante fue un conversatorio sobre el deber de memoria entre Gonzalo Sánchez y Félix Reátegui -coordinador operativo del informe final de la Comisión de la Verdad y Reconciliación en el Perú- en la Feria del Libro de Bogotá, el 25 de abril de 2012. Allí, estos dos intelectuales con similares recorridos académicos y políticos en sus respectivos países hablaron, entre muchos temas, de la construcción reciente de la noción de víctima, de las oportunidades de reparación y reconocimiento que se han abierto para ellas en los últimos años, de las posibilidades y limitaciones que tiene la reconstrucción de la memoria frente a las expectativas de las comunidades. Sánchez resaltó la relación entre memoria y democracia, afirmando que la primera es un elemento central de la segunda. Desde su perspectiva, la memoria crea democracia pero, a la vez, responde a reclamos de la democracia: "La memoria en escenarios de comisión tiene la función de hacer un balance de las violencias, de las impunidades, de los vacíos de la democracia y ayudar a pensar un futuro distinto. En Colombia, todo está abierto. Se espera que la memoria ayude a hacer balance y dar sentido a una violencia que parece completamente irracional" (Sánchez y Reátegui, 2012). Por eso, sostiene, antes de cualquier acción o a la par con ella, es imperioso conocer y re-conocer lo que ha sucedido. Por su parte, Reátegui (2012), expresó que una comisión de la verdad no es el punto de llegada de un proceso de memoria sino un punto de partida. En Colombia, sin embargo, por tratarse de un escenario peculiar, es un punto intermedio. Se refirió también al mandato que tiene el Centro de Memoria Histórica en Colombia de no construir una verdad oficial, diciendo que, de hecho, no puede aspirarse a una memoria con tal carácter pues los procesos de memoria son ingobernables: "no se puede decir por decreto qué se puede recordar".

En el próximo capítulo analizaremos en detalle los informes del Grupo/Centro de Memoria en especial el ¡Basta ya! indagando por sus condiciones de producción, las formas de elaboración de sentidos, la inclusión de las iniciativas civiles de memoria y, en general, las estrategias empleadas para concatenar las versiones de los hechos y entregar una narración que, aunque constituida desde un ente oficial, no se presenta como la verdad oficial sobre el conflicto armado. 


\title{
CAPÍTULO 3
}

\section{LAS MEMORIAS QUE SEREMOS Análisis del informe general sobre el conflicto armado del Grupo de Memoria Histórica}

\begin{abstract}
La memoria no era para después de la guerra, pues ellos y ellas podrían ya no estar y los riesgos de olvido serían mayores. La memoria, según ellos, debía hacerse en medio de la guerra, para detenerla, denunciarla, reclamar, transformar y construir la paz.
\end{abstract}

¡Basta ya! Colombia: Memorias de guerra y dignidad

\subsection{Una narración vertiginosa. Panorama de la producción del Grupo/Centro de Memoria Histórica}

En el presente capítulo procuraremos hacer un análisis o, por lo menos, al decir de Geertz, una descripción densa ${ }^{67}$ de la producción del Grupo/Centro de Memoria Histórica, haciendo especial énfasis en el informe general sobre el conflicto armado, titulado ¡Basta ya! Colombia: Memorias de guerra y dignidad. Este informe fue entregado en un acto público al presidente de la república el 24 de julio del año 2013, y constituye la culminación de la tarea inicial que le había sido asignada al Grupo en su origen por la Ley de justicia y paz. En el prólogo a dicho informe, Gonzalo Sánchez afirma que se trata del producto mediante el cual se da cumplimiento al mandato legal conferido inicialmente al área de memoria histórica del CNRR, la cual, como hemos indicado en otros apartados, era la construcción de un relato sobre el origen y devenir de los grupos armados ilegales. Procuraremos mostrar en nuestro relato el carácter esencialmente político y ético de este y otros informes del $\mathrm{GMH}$, develando una intencionalidad clara y una coherencia de su obra que puede rastrearse tanto en la estructura y organización de los informes como en aquellas estrategias discursivas que emplean para lograr un impacto en los potenciales lectores. El uso del lenguaje y de la imagen es, como se verá, un sello distintivo de la producción del Grupo, el cual permite identificar dimensiones y ejes articuladores que apelan a distintos niveles de interpretación y se dirigen, en un mismo texto, al experto o estudioso del conflicto y la violencia colombianos, como al ciudadano común que empieza a preguntarse por una faceta de la realidad de su país.

La estrategia del Grupo de Memoria Histórica ${ }^{68}$ para cumplir con la labor encomendada consistió en la selección de algunos casos emblemáticos en todo el territorio nacional, a

\footnotetext{
${ }^{67}$ En La interpretación de las culturas, Clifford Geertz, basándose en G. Ryle, defiende un tipo particular de interpretación de fenómenos sociales que, sin llegar a ser un análisis basado en categorías teóricas fuertes o que postule nuevos conceptos y nociones, va más allá de la mera exposición, paso por paso, de las formas en que ciertos comportamientos, acciones y situaciones sociales se presentan. Aunque tiene algo de esto, la manera en que son presentados por el investigador permite entrever, en su manera de narrar, los aspectos significativos de aquello que se está describiendo, la articulación de los sentidos que entran en juego, los contextos en los que tiene lugar, con el propósito principal de que pueda ser comprendido por alguien ajeno a ello.

${ }^{68}$ En adelante, centraremos nuestra referencia sobre el Grupo -y no el Centro de Memoria Histórica-, puesto que de este modo se siguió nombrando en el $\mathrm{CMH}$ al área encargada de las investigaciones documentales y de campo que permitieron la elaboración del informe ¡Basta ya!, tal como se evidencia en su prólogo, cuando
} 
partir de los cuales pretendió trazar un mapa de la presencia y estragos del conflicto armado en el país, distinguiendo actores, motivaciones y formas de victimización.

Hay aquí un primer elemento a resaltar del trabajo del GMH: la búsqueda de establecer relaciones entre lo local y lo nacional a partir de la demostración empírica de que han existido prácticas comunes en la dinámica del conflicto que fueron más allá de las particularidades de cada región y que hicieron parte de estrategias sistemáticas de los actores armados para establecer dominios sobre territorios valiosos por distintos motivos: desde su riqueza en términos de recursos naturales y proyectos de explotación y expansión, hasta su ubicación estratégica como rutas para la movilización inadvertida de tropas, armas y estupefacientes. Este presupuesto, unido a la convicción de que la historia y la memoria del conflicto armado colombiano no podían ser contadas de manera simple, justificó la metodología de los casos emblemáticos que tendrían que escribirse antes de poder elaborar un relato global, esa suerte de memoria nacional que busca ser el ;Basta ya!, no en el sentido de una verdad oficial y sin fisuras sino como un relato que refleja la realidad intrincada y compleja de todo un país.

Luego de hacer un seguimiento del trabajo del GMH teniendo en cuenta la forma en que comenzó y la tarea inicialmente asignada, es perceptible un uso estratégico de recursos, medios y contactos. Evidentemente, no se limitó a la construcción de un solo informe que respondiera a la pregunta que se formuló desde un comienzo, que apuntaba a la aparición y evolución de grupos armados ilegales y que, según relata Jaramillo (2011, p. 299), pretendía instalar la fecha de 1964 (año del surgimiento de las FARC) como origen de los mismos, situando entonces en el principio de uno de los principales problemas sociales y políticos del país a un actor específico: la guerrilla de las FARC. Esta estrategia concordaba con la posición del entonces presidente Álvaro Uribe Vélez, que se encargó durante su mandato de erigir a esta guerrilla como el enemigo por antonomasia del Estado. Sin embargo, es palpable en los informes del GMH que en ningún momento se plegó a esta interpretación y, en cada uno de los casos analizados, señala a los diversos actores que participaron en los hechos narrados y atribuye responsabilidades tanto a los grupos armados al margen de la ley como a la fuerza pública y otras instituciones estatales cuando así lo ameritan los testimonios de víctimas y sobrevivientes o las investigaciones de organismos judiciales, periodistas o corporaciones con presencia en cada región.

La periodización que comenzaba a partir de 1964 fue uno de los aspectos más criticados por Jaramillo (2011) en su trabajo sobre las comisiones de estudio sobre la violencia, justamente porque suponía la sumisión ante los presupuestos del gobierno de Uribe. Igualmente, había en su tesis una preocupación ante la posibilidad de que se hiciera una confección del pasado que negara, junto con la existencia del conflicto armado, la responsabilidad histórica del Estado como actor dentro del mismo, así como la participación directa de agentes estatales en hechos victimizantes hacia la población civil. Ambas críticas, plenas de sentido en el momento en que Jaramillo escribió su texto, fueron de algún modo superadas por el GMH merced a coyunturas políticas específicas que le dieron un giro al discurso que enmarcaba su trabajo. En primer término, la periodización establecida para su informe

Gonzalo Sánchez afirma: “En su desarrollo, el Grupo de Memoria Histórica —adscrito primero a la Comisión Nacional de Reparación y Reconciliación- CNRR- y ahora parte del Centro Nacional de Memoria Histórica- se propuso dar respuesta a este requerimiento desde la consideración de los actores armados ilegales no solo como aparatos de guerra, sino especialmente como productos sociales y políticos del devenir de nuestra configuración histórica como país." (Sánchez, 2013, p. 16). 
general dejó de estar circunscrita al período $1964-2005^{69}$, y pasó a abarcar el período más amplio de 1958-2012, el cual, más que marcar un inicio y un fin del conflicto armado (cosa que, de hecho, no tendría sentido hacer, en tanto dicho conflicto persistía en el 2012), resaltan lo que ha sido un proceso de larga duración en el Estado colombiano desde el "fin" del período de La Violencia (el cual suele identificarse, en la literatura académica, con el establecimiento del pacto bipartidista del Frente Nacional, en 1958) hasta el momento preciso en el cual el GMH produce el informe ¡Basta ya! Vemos aquí una ruptura del Grupo con la posición hegemónica del gobierno que los vio nacer y una continuidad con la tradición histórica y académica que emblematizó el período de La Violencia como diferente (aunque emparentado) con el surgimiento y duración del conflicto armado. Es precisamente en el uso de esta categoría en la que hallamos una contraargumento para la segunda de las críticas de Jaramillo, puesto que con la firma de la Ley de víctimas se reformó el marco que había sido predominante en la agenda política colombiana durante los dos cuatrenios de Uribe y se volvió a usar la noción de conflicto armado, transformándose de este modo el mandato del GMH y abriéndose la posibilidad para que dentro de sus informes se señalara al Estado colombiano como un actor central dentro del mismo, y se le atribuyeran las responsabilidades que le competían dentro de la prolongada historia de la confrontación.

Si se tiene en cuenta que durante cuatro años (entre 2007 y 2011), el GMH fue únicamente una sub-área dentro de una Comisión -la CNRR- que tenía funciones más amplias de acompañamiento al proceso de reparación de víctimas y reinserción de personas que estaban dejando las armas en virtud de un proceso de negociación, es llamativa la magnitud y variedad de su producción durante este período. Valiéndose de una hábil estrategia de búsqueda de recursos externos -que suele ser bien recibida por el Estado, pues de ese modo no todos los fondos salen de sus arcas-, logró adelantar varias investigaciones previas al estudio de los grupos armados como tales y consiguió, también, justificar de una manera lo suficientemente convincente la necesidad de realizar aproximaciones locales a casos emblemáticos de la confrontación armada en el país antes de elaborar un informe general que diera cuenta de tan compleja problemática. Tal es así que, antes de la entrega de este informe, el GMH trabajó durante seis años -más que cualquier otra comisión estatal encargada del estudio del conflicto- y presentó una cantidad considerable de informes, no sólo sobre casos emblemáticos de desplazamientos, atentados o masacres, sino también sobre temáticas específicas asociadas al conflicto armado, como la tierra, la situación de las mujeres en la guerra, el secuestro, e incluso un balance de la aplicación de la Lay de Justicia y Paz.

Esta abundante producción evidencia, a nuestro juicio, al menos dos cosas: primero, la capacidad estratégica del equipo y su director, que supieron aprovechar una coyuntura y el espacio que allí se abrió para la memoria histórica, conjugándola con el interés de la época por este asunto; en segundo lugar, un cierto afán por producir todo lo que fuera posible en el tiempo de duración de sus funciones, que inicialmente estaba condicionado por la existencia de la CNRR, la cual había sido planeada para un período de ocho años. Sin embargo, la Ley de Víctimas (2011) no sólo amplió el período de existencia del GMH sino que lo hizo autónomo, le confirió nuevas funciones, y le asignó un nombre que pone de relieve

\footnotetext{
${ }^{69}$ Esa periodización inicial, que había sido impuesta por el gobierno de Uribe, establecía como fechas emblemáticas de inicio y finalización de la "amenaza terrorista" (según el discurso oficial del momento) el año de surgimiento de las FARC y aquel en que se logró un acuerdo de entrega de armas con las autodefensas, con todas las inconsistencias que esto supone y que ya han sido objetos de discusión en otros apartados de esta misma tesis.
} 
su carácter de articulador de iniciativas en todo el país, así como la trascendencia de su misión investigativa: Centro Nacional de Memoria Histórica -CNMH-.

Podemos identificar entonces dos momentos en el trabajo del Grupo/Centro de Memoria Histórica, correspondientes justamente a su existencia bajo cada una de estas denominaciones (Grupo y Centro). Como Grupo adscrito a la CNRR elaboró los siguientes informes:

- Trujillo. Una tragedia que no cesa (2008)

- El Salado. Esa guerra no era nuestra (2009)

- Memorias en tiempo de guerra. Repertorio de iniciativas (2009)

- Caja de herramientas Recordar y narrar el conflicto: herramientas para construir memoria histórica (2009)

- Bojayá. La guerra sin límites (2010)

- La Rochela. Memorias de un crimen contra la justicia (2010)

- La masacre de Bahía Portete. Las mujeres Wayú en la mira (2010)

- La tierra en disputa. Memorias del despojo y resistencias campesinas en la Costa Caribe 1960-2010 (2010).

- Mujeres y guerra. Víctimas y resistentes en el Caribe colombiano (2010)

- Silenciar la democracia. Las masacres de Remedios y Segovia, 1982-1997 (2010)

- San Carlos. Memorias del éxodo en la guerra

- La huella invisible de la guerra. Desplazamiento forzado en la Comuna 13 (2011)

- El orden desarmado. La resistencia de la Asociación de Trabajadores Campesinos del Carare (2011)

- La masacre de El Tigre, Putumayo (2011)

Se trata en total de 15 libros, editados con financiación del Estado y organismos de cooperación internacional, disponibles en librerías de todo el país y colgados para su descarga libre y gratuita en el sitio web del CNMH. La extensión de cada uno varía entre las 150 y las 400 páginas, y todos son el resultado de meses o años de trabajo de campo e investigación documental en los que participa un nutrido número de personas entre coordinadores del informe, relatores, investigadores y auxiliares que se distribuyen actividades como entrevistas, talleres constructivos, consulta de fuentes primarias y secundarias y sesiones de discusión acerca de la estructuración de cada texto.

Hacemos este somero inventario de los informes del GMH por varios motivos: en primer lugar, para ilustrar tanto el volumen de producción del Grupo como la variedad de temas que son tratados en los informes previos a aquel general sobre el surgimiento y evolución de los grupos armados ilegales, misión inicial y única del $\mathrm{GMH}$ en el momento de ser constituido, y el cual, dicho sea de una vez, no fue entregado en el tiempo cronológico correspondiente -de manera formal- a su existencia como $\mathrm{GMH}$, sino que salió a la luz pública en julio del año 2013. A excepción de todos los informes publicados a partir del año 2012, que son presentados en nombre del Centro de Memoria Histórica, el informe general es presentado como un producto del $\mathrm{GMH}$, a fin de ser consecuentes con el hecho de que este representa el cumplimiento cabal del mandato que le dio origen.

Otro de los asuntos que nos interesa resaltar es precisamente cómo, a pesar de haber surgido con una función aparentemente acotada, cuyo insumo final hubiera podido perfectamente haber sido un único informe (como en el caso de las comisiones anteriores), el GMH logró prolongar el alcance de sus acciones y presentar toda una colección de textos que pretendían, en su conjunto, dar cuenta de la magnitud y omnipresencia de la guerra, además de ser pasos previos a la construcción del informe general. Después de hacer un 
análisis de la ley que hizo posible la existencia y funcionamiento del GMH y contrastarla con su producción, inferimos ${ }^{70}$ que el Grupo encontró en la amplia definición que en la misma se hace del deber de memoria del Estado una justificación para redimensionar su trabajo más allá del "informe público sobre las razones para el surgimiento y evolución de los grupos armados ilegales” (República de Colombia, 2005, artículo 51). Algunos artículos más adelante, en la misma ley, se define del siguiente modo el deber de memoria: "el conocimiento de la historia de las causas, desarrollos y consecuencias de la acción de los grupos armados al margen de la ley deberá ser mantenido mediante procedimientos adecuados, en cumplimiento del deber a la preservación de la memoria histórica que corresponde al Estado" (República de Colombia, 2005, artículo 56). Aunque en principio no parece haber mucha diferencia entre los enunciados de los artículos citados, el último de ellos es más específico en cuanto a lo que debe documentarse $y$, teniendo en cuenta que los grupos armados ilegales han operado por varias décadas en el país, aparece como una petición razonable de parte del GMH elaborar informes parciales y regionales para presentar un panorama de las causas, desarrollos y consecuencias de sus acciones que permitieran ir avanzando de a poco en la elaboración de un relato de carácter nacional.

A lo largo de nuestro texto, de manera consciente, hemos procurado hablar de confrontación armada en Colombia cuando es la propia voz la que se expresa, no porque desconozcamos la existencia del conflicto armado interno, sino porque es de suma importancia para nuestro análisis resaltar las diferencias que, en términos de reconstrucción oficial de la memoria histórica, supone que el gobierno de turno avale o vete el uso de la noción de conflicto armado. Como ya hemos señalado, cuando se promulgó la Ley de Justicia y Paz que posibilitó la creación del GMH, estaba vedado en las instituciones gubernamentales referirse al conflicto armado y se trató de imponer la idea de que lo que había en Colombia era una amenaza terrorista. A raíz de esto, el texto de la Ley en cuestión no menciona en ningún momento el conflicto armado, y el deber de memoria se circunscribe al conocimiento de las acciones de los grupos armados ilegales, lo cual excluye del relato aquellas acciones ilegales cometidas por las fuerzas regulares del Estado, además de soslayar el carácter político de la confrontación bélica que se ha estado librando por décadas en el país.

El GMH, muy tempranamente, incorporó a su presentación la noción de conflicto, y en la que aún (marzo de 2014) puede leerse en su página web, afirman que su objetivo es "elaborar y divulgar una narrativa sobre el conflicto armado en Colombia que identifique las razones para el surgimiento y la evolución de los grupos armados ilegales. Esta última parte está tomada textualmente de la Ley de Justicia y Paz, pero el inicio es algo que no se cita textualmente de ninguna ley o decreto, lo que indica que es una descripción que el propio Grupo acuña para su labor. En efecto, pese a que habría sido de esperarse que en sus primeros informes se omitiera hablar abiertamente de conflicto armado, por el contexto político en que fueron producidos, es posible constatar que desde la primera de sus publicaciones, en el año 2008, utilizan esta categoría. Y hacen más: eligen como caso emblemático inaugural una "masacre continuada" q11 que ha incluido asesinatos, amenazas y

\footnotetext{
${ }^{70}$ Por lo pronto, y en vista de que durante la elaboración de la tesis no fue posible concertar una cita con las directivas del CMH que confirme o desmienta esta interpretación, se presenta a modo de inferencia.

${ }^{71}$ La noción de "masacre continuada" es acuñada por el Grupo de Memoria Histórica para englobar en ella una serie de asesinatos que se sucedieron por años en este municipio. En la introducción al informe, dicen: "[...] el Gmh recurre a la calificación de "Masacre continuada de Trujillo", como forma de reconocimiento de la dimensión colectiva y prolongada de los crímenes que tuvieron lugar en esta zona del Valle, destacando al mismo tiempo la crueldad y la sevicia en la ejecución de los hechos delictivos. La noción de masacre, a nuestro juicio, pone en evidencia el impacto social y cultural de los mecanismos de violencia empleados. La designación
} 
hasta profanaciones a los monumentos memoriales, y en la que están implicados agentes del Estado que colaboraron con narcotraficantes y grupos paramilitares en la ejecución de los delitos. Textualmente, en la introducción del informe se justifica la elección de este municipio del departamento del Valle del Cauca y lo sucedido allí para comenzar con la serie de informes de Memoria Histórica, así:

Trujillo es un caso límite por la atrocidad de lo allí acontecido y por la repetida vulneración de los derechos de las víctimas por parte de numerosos actores, incluido el Estado. Trujillo ilustra el impacto desarticulador del terror que han vivido tantas comunidades y las dinámicas perversas del conflicto armado interno en todo el país. Trujillo ofrece la oportunidad de abordar una memoria histórica que sigue teniendo numerosos rasgos de presente. $(\mathrm{GMH}, 2008)$

Que esto haya sido publicado y difundido pese a la posición del mandatario del momento, evidencia una vez más las tensiones entre distintas posiciones al interior del Estado, el cual no puede ser pensado como una unidad que funciona necesariamente de acuerdo con las directrices de su cabeza visible. También da cuenta de las maniobras que es posible hacer en una democracia que, aunque precaria, opera formalmente y puede ser usada o invocada para sostener discursos contrahegemónicos en disonancia con el que pretendía ser impuesto por el presidente Uribe Vélez, pero que no podía dictaminarse por decreto. Si bien una parte del discurso oficial se plegaba ante la insistencia del presidente de no hablar de conflicto armado, el uso de tal noción no podía proscribirse abiertamente y, en virtud de que cuando se creó el GMH se definió que se trataría de una comisión técnica que gozaría de autonomía académica e investigativa para la realización de su trabajo, no hubo instancias de censura que impidieran que un texto con semejantes aseveraciones viera la luz pública bajo el manto de la institucionalidad. Según Mauricio Builes, comunicador del GMH desde sus inicios, esto ha sido respetado al pie de la letra y, de no haber sido de este modo, tanto Gonzalo Sánchez como su equipo habrían suspendido su trabajo ${ }^{72}$.

En el plano discursivo, como en muchos otros, el GMH fue estratégico en el momento de dar nombre a sus informes. Una mirada rápida sobre los títulos de los quince elaborados entre 2008 y 2011, pone de manifiesto el uso privilegiado de la categoría de guerra, que aparece en seis de ellos, mientras que la noción de conflicto (a secas, sin el adjetivo "armado") es usada en una única ocasión que no corresponde a ningún caso emblemático y que tiene un carácter fundamentalmente metodológico (se trata de la cartilla Recordar y narrar el conflicto: herramientas para construir memoria histórica, del 2009). Aunque anteriormente habíamos señalado que el uso de la noción de guerra tiene toda una fundamentación en elaboraciones previas de Gonzalo Sánchez y representa una toma de posición sobre el carácter político del conflicto, consideramos que se trata también de una estrategia retórica que funciona en una doble vía: en primer lugar, desplaza la centralidad de la noción de conflicto armado, evitando que se cierna sobre los informes una suspicacia inicial de funcionarios afectos a la directriz uribista; en segundo lugar, en relación con el público lector, la palabra guerra llama la atención sobre una confrontación de gran magnitud, que va más allá de casos aislados que se registran en regiones apartadas del país.

A mediados del 2011 se inicia un proceso de transición del GMH, el cual desaparece como sub-área de la CNRR y se transforma en una parte central pero no única del nuevo Centro de

como masacre de la cadena de crímenes es también una opción que afirma la solidaridad con la comunidad de víctimas, y la condena moral a los perpetradores, dado que ese nombre de masacre rompe la pretensión del victimario de ocultar o minimizar sus crímenes". (GMH, 2008a, p. 14)

${ }^{72}$ Entrevista realizada a Mauricio Builes el 7 de enero de 2014 en la ciudad de Medellín. 
Memoria Histórica, cuyas funciones fueron detalladas en el capítulo precedente. La etapa del $\mathrm{CMH}$ comienza entonces con la producción de finales del 2011 y sigue abierta en el momento de escritura de esta tesis. Hasta la fecha, en poco más de dos años de operación, ha presentado los siguientes informes:

- Mujeres que hacen historia. Tierra, cuerpo y política en el Caribe colombiano (2011)

- El Placer. Mujeres, coca y guerra en el bajo Putumayo (2012)

- "Nuestra vida ha sido nuestra lucha". Resistencia y memoria en el Cauca indígena.

- Serie sobre la Ley de Justicia y Paz, en tres tomos: (2012)

$\sim$ ¿Verdad judicial o verdad histórica?

$\sim$ Los silencios y los olvidos de la verdad

$\sim$ Tierras y territorios en las versiones de los paramilitares

- Encuesta Nacional: ¿Qué piensan los colombianos después de siete años de Justicia y Paz? (2012)

- Una verdad secuestrada. Cuarenta años de estadísticas de secuestro. 1970-2010. (2013)

- Guerrilla y población civil. Trayectoria de las FARC 1949 - 2013 (2013)

- Una sociedad secuestrada (2013)

- La política de reforma agraria y tierras en Colombia. Esbozo de una memoria institucional. (2013).

- Desafíos para la reintegración. Enfoques de género, edad y etnia (2013). En el caso de esta última publicación llama la atención el cambio en el color de la portada, que ya no es negra como la de todos los informes anteriores, sino granate. El tema es también disímil y está más enfocado a un posible escenario de posconflicto, lo que sugiere una intencionalidad en la variación del color.

Con la transición del GMH hacia el CMH se da un giro en el tipo de producción, que deja de estar centrada en los casos emblemáticos, con énfasis regional, para consolidar una reflexión temática, cada vez más enfocada en el esclarecimiento histórico -entendido como la comprensión de procesos de duración extensa que han estado presentes a lo largo de la trayectoria del conflicto armado- y a la elaboración de recomendaciones para el Estado y la sociedad que hagan factible el acoplamiento de ambos a los desafíos que suponen las diferentes negociaciones que se han llevado a cabo y se siguen adelantando con los grupos armados ilegales, tales como la reintegración de sus miembros a la vida civil, las garantías de no repetición para las víctimas, la restitución de tierras y derechos, y la participación en política por las vías democráticas.

\subsection{La memoria como resistencia y como acto político: posición fundamental del GMH}

Cuando se recorren los informes del GMH, tanto los de casos emblemáticos como los temáticos, se revela un presupuesto general que los atraviesa a todos: hacer memoria histórica es un acto de resistencia de las comunidades victimizadas y es, también, un ejercicio político de toma de posición, de demanda ante las instituciones que les deben protección en tanto sociedad civil. La memoria es, desde su perspectiva, una vía para la construcción democrática y esa es una de las razones esenciales que dota de sentido la búsqueda de su recuperación.

Desde el primero de sus informes, realizado con cierta premura y sin haber terminado de decantar lo que sería su metodología de trabajo, están echadas sin embargo las bases de lo que estructuraría la producción venidera: 
El GMH inicia con el estudio de la Masacre de Trujillo la construcción de la memoria histórica del conflicto armado interno en Colombia. Este ejercicio se funda en la convicción de que es posible establecer un vínculo indisoluble entre la construcción de memorias y la construcción democrática. Se trata de un proceso que parte del reconocimiento de:

1. El carácter político de la memoria. La memoria es un campo de lucha en el que se dirime qué versión del pasado debe prevalecer en función del futuro que se quiere construir. Pero la memoria se construye desde relaciones asimétricas. Es decir, no todas las memorias acceden en igualdad de condiciones a la escena política. Indígenas y campesinos no están en posiciones equivalentes a las élites. Las víctimas no tienen los mismos recursos para decir su verdad que los victimarios.

2. El papel fundamental de la memoria histórica en los procesos de democratización en situaciones de conflicto. Uno de los temas de debate en una transición, por precaria que ésta sea, es precisamente el de la evaluación del pasado traumático y de las responsabilidades sociales, institucionales e incluso criminales frente a éste. Memoria y democracia están íntimamente ligadas. Se hace memoria y se construye verdad para que les sirva a las víctimas y a la sociedad, para la transformación del pasado que se quiere superar.

3. La memoria histórica no es de ningún modo sustituto de la justicia. Es un escenario de reconocimiento de las diferencias con miras a un proyecto incluyente, y en ese sentido es también una plataforma para el diálogo y la negociación.

4. La memoria es en sí misma una forma de justicia. Esto es particularmente válido en casos donde la institucionalidad ha fallado de manera protuberante. A través de la memoria se responsabiliza a los perpetradores y se hacen visibles las impunidades y los silencios. Cuando flaquea la verdad judicial, se eleva el papel de la memoria: ésta se convierte en el nuevo juez.

5. La memoria histórica es una forma de reparación. Ella hace parte de los reclamos esenciales de las víctimas. En otros términos, la memoria es una instancia de reconocimiento del sufrimiento social que fue negado, ocultado o suprimido de la escena pública bajo el impacto mismo de la violencia. No se trata sólo o preponderantemente de la compensación económica, sino de respuestas a las preguntas que persiguen la mente de las víctimas: ¿qué pasó?, ¿quién lo hizo?, ¿por qué lo hizo?, ¿dónde, cómo y cuándo?

6. La memoria es un mecanismo de empoderamiento de las víctimas. En el ejercicio de memoria las víctimas individualizadas, locales y regionales, pasan a víctimas organizadas, víctimas ciudadanos, creadoras de memorias ciudadanas. En Colombia la violencia paraliza y destruye, pero también ha obligado a la movilización y generación de nuevos liderazgos. Hacer memoria es en todo caso recuperar sentido. Esto exige adentrarse en los contextos, interpretar a los actores sociales y políticos, en sus relaciones, motivaciones, estrategias y discursos, y dar cuenta del juego de reciprocidades de los diferentes niveles (nacional, regional y local) en la producción de la violencia y construcción de la memoria. Hechos, contextos y actores son las tres dimensiones desde las cuales se aborda la trama que se teje entre violencia y memoria.

Citamos in extenso este fragmento porque refleja en unos pocos párrafos cuál es el horizonte al que apunta el GMH y desde dónde lo hace. En primer lugar, desafía al gobierno de la época, volviendo a afirmar que se trata de un estudio del conflicto armado, pese a que lo habitual en las producciones oficiales durante ese tiempo era omitir cualquier referencia a esta categoría, alineándose así con la directriz presidencial. Después, establece la apuesta democratizadora de los ejercicios de memoria que acaba de emprender como entidad para pasar, a continuación, a enunciar seis puntos clave en relación con la memoria que servirán de guía para la confección de este y los demás informes a su cargo. Comienza por reconocer la dimensión política de la memoria pero también el hecho de que en este terreno las fuerzas son asimétricas, lo que justifica que el GMH privilegie hacer eco de las voces de las víctimas, especialmente las de aquellas que tienen las mayores dificultades para hacerse 
escuchar en la esfera pública y que son, además, las más azotadas por los embates del conflicto: campesinos e indígenas. En trabajos posteriores, el GMH profundizará en este enfoque diferencial, y otorgará también un estatus especial a los relatos de mujeres y niños $^{73}$. El segundo punto especifica de qué forma entienden el aporte que la memoria puede hacer a la democracia en contextos de transición, indicando que su ejercicio es una forma de evaluación de los pasados traumáticos y, concretamente, de las responsabilidades frente a este, lo que facilita el reconocimiento de quiénes y de qué forma han participado en el sometimiento de una población y, eventualmente, propiciaría que sus habitantes se hagan conscientes de que sus acciones como sujetos políticos pueden transformar estas situaciones recurrentes. Los puntos 3 y 4, referidos a la relación entre memoria y justicia, parecen contradictorios, pero son más bien complementarios. En ellos se aclara que la primera no puede sustituir a la segunda en términos de investigación y condena pero que, desde cierta perspectiva, la memoria es una forma de justicia cuando la precariedad institucional o la desidia de los funcionarios judiciales obstaculizan la realización plena de esta. Así, allí donde no ha habido resultados formales en las investigaciones o donde la posibilidad de denuncias de las víctimas se ve limitada por asuntos de forma -tal como ha sucedido en los juicios a paramilitares cobijados por la Ley de justicia y paz, que privilegia sus propias versiones libres sobre los delitos cometidos y limita la participación de las víctimas $^{74}$, , el testimonio vuelto memoria es una vía alternativa para hacer visibles los padecimientos de personas y comunidades, denunciar ante la opinión pública a los autores de los hechos y hacer frente a las estigmatizaciones de las que muchas veces han sido objeto por el simple hecho de habitar una zona o por participar en actividades que buscan la reivindicación de derechos ${ }^{75}$. Tal vez los puntos 4 y 5 pudieran fusionarse, pues si la memoria es una forma de justicia, lo es justamente en su dimensión de reparación: cuando el aparato de la justicia falla, se busca por lo menos el reconocimiento social de lo padecido y el conocimiento, si no la condena, de las situaciones y responsables que llevaron al asesinato o desaparición de familiares o amigos, al desplazamiento forzado, a los períodos prolongados de amenaza y zozobra, entre muchas otras modalidades de violencia.

En el ¡Basta ya! se profundiza en esta perspectiva y se resalta el hecho de que esta resistencia ha estado presente en medio de la guerra, demostrando que memoria y conflicto no son necesariamente procesos secuenciales, y que pueden hacerse -como lo titula uno de los primeros informes del $\mathrm{GMH}-$ memorias en tiempo de guerra:

Rompiendo todos los cánones de los países en conflicto, la confrontación armada en este país discurre en paralelo con una creciente confrontación de memorias y reclamos

\footnotetext{
${ }^{73}$ En conversación con el comunicador del CNMH, en enero de 2014, este anticipó que entre los informes que actualmente están en preparación hay uno dedicado exclusivamente a las memorias de niños y niñas en medio de la guerra, los cuales vienen a complementar los tres que ya existen sobre las mujeres y la guerra.

${ }^{74}$ Elsa Blair et. al., en De memorias y de guerras, sostienen: "[... ] son los victimarios los que tienen la palabra. En este sentido, y como lo señalaba María Teresa Uribe, en el marco de la Ley de Justicia y Paz, el escenario de la justicia es el reino del victimario. Es él quien tiene derecho a la palabra, debe rendir una versión libre en la cual no está obligado a decir la verdad ni a confesar todos los crímenes, no se trata pues de la verdad del victimario sino de un relato fragmentado circunscrito a algunos hechos aislados, presumiblemente de aquellos de los cuales las autoridades pueden tener noticias (...). Este corpus normativo parece estar tejido con olvidos y remendado con silencios y desde allí no es imaginable qué tipo de reparación pueda desplegarse o qué tipo de paz construirse (Uribe, 2006:343)".

${ }^{75}$ Varios de los informes de GMH dan cuenta de los efectos perversos de la estigmatización y las variadas modalidades en que se presenta: el caso del municipio de El Salado, por ejemplo, ilustra lo que pasó en una comunidad acusada en su conjunto de ser guerrillera por la presencia predominante que en su territorio mantuvo las FARC durante varios años; en el informe sobre Segovia y Remedios se da cuenta del asesinato sistemático de militantes y simpatizantes de un partido político de izquierda; en el ¡Basta ya! hay varios apartados dedicados tanto a los efectos como a las memorias de la estigmatización.
} 
públicos de justicia y reparación. La memoria se afincó en Colombia no como una experiencia del posconflicto, sino como factor explícito de denuncia y afirmación de diferencias. Es una respuesta militante a la cotidianidad de la guerra y al silencio que se quiso imponer sobre muchas víctimas (GMH, 2013, p. 13).

Para el $\mathrm{GMH}$, la memoria es signo de resistencia y, además, su ejercicio en medio de la guerra es una característica diferencial del conflicto armado colombiano, lo cual tiene sentido por la prolongada duración del mismo y sus múltiples manifestaciones, algunas de las cuales pueden haberse cerrado parcialmente, pero no sin dejar estragos sobre la población y desatar otras disputas, otras presencias armadas y, también, otras ausencias. La memoria es, en suma, "[...] una expresión de rebeldía frente a la violencia y la impunidad" (GMH, 2013, p. 13).

\section{3 ¡Basta ya! Un grito en medio del conflicto. Estructura del informe general y estrategias discursivas del GMH}

\subsubsection{El manejo de la palabra: un rasgo distintivo del $\mathrm{GMH}$}

Cada informe del Grupo/Centro de Memoria Histórica lleva un título que alude directa e inmediatamente a lo esencial de los hechos que serán narrados y analizados, resaltando dos niveles: el tipo de hecho victimizante que predomina en cada caso (masacres, desplazamientos, despojo de tierras, persecución contra la justicia, entre otros), y los efectos políticos y simbólicos de las acciones perpetradas (el silenciamiento de la democracia, el desplazamiento -o éxodo, según uno de los títulos-, las huellas invisibles de la guerra, la resistencia o la lucha).

Todos están organizados de manera similar: comienzan con los agradecimientos a pobladores y sobrevivientes, que entregan sus testimonios. A entidades nacionales e internacionales, agrupaciones, empresas. A personas específicas. Se menciona al final que el $\mathrm{GMH}$ es el único de lo responsable por lo escrito y se "hace público reconocimiento al estricto cumplimiento que se le ha dado a la autonomía académica y administrativa" de su labor. Además, se señala el carácter público de los informes y el hecho de que pueden ser "reproducidos, copiados, distribuidos y divulgados siempre y cuando no se altere su contenido y se cite la fuente".

Luego viene un prólogo, por lo general a cargo de Gonzalo Sánchez, director del Grupo y una de las voces más autorizadas en Colombia para hablar de la violencia y el conflicto armado, por su larga trayectoria investigativa en la materia. Se trata habitualmente de un texto breve, que sintetiza la problemática desarrollada en el informe, establece relaciones de los hechos con un pasado relativamente lejano (normalmente el período de La Violencia de los años cincuenta, consecuente con el hecho de que la periodización asumida por el grupo concibe el conflicto armado como "heredero" de esta Violencia y construye sus relatos tomando como punto de referencia el año de 1958), retoma elementos teóricos sobre violencia y memoria y lanza críticas, preguntas y reflexiones que están dirigidas a la sociedad colombiana en su conjunto. Cada prólogo tiene una doble función de exhortación e invitación, pues a la vez que señala responsabilidades y hace cuestionamientos que involucran al lector y la posición que ha asumido frente a las vivencia traumáticas de otros ciudadanos colombianos, proporciona también razones éticas y morales que justifican la lectura de los informes como una primera forma de acercarse a esa realidad ominosa (próxima y a la vez ajena, en un sentido freudiano) que también le compete y que es necesario comprender. Un buen ejemplo de esto lo encontramos en el prólogo al ¡Basta ya!, cuando dice: 
¿A quiénes concierne la guerra? En la visión kantiana, el daño que se hace a una víctima es un daño que se le inflige a toda la humanidad. De allí el compromiso axiológico de protección a las víctimas, consagrado en las normas internacionales de Derechos Humanos y del Derecho Internacional Humanitario. No obstante, pareciera que en los hechos se requiere la condición de parte directamente afectada, interesada, para que el tema de las responsabilidades frente al conflicto desencadene la acción colectiva. Por ello, aunque el conflicto armado en el país ha cobrado millares de víctimas, representa para muchos conciudadanos un asunto ajeno a su entorno y a sus intereses. La violencia de la desaparición forzada, la violencia sobre el líder sindical perseguido, la violencia del desplazamiento forzado, la del campesino amenazado y despojado de su tierra, la de la violencia sexual y tantas otras suelen quedar marginadas de la esfera pública, se viven en medio de profundas y dolorosas soledades. En suma, la cotidianización de la violencia, por un lado, y la ruralidad y el anonimato en el plano nacional de la inmensa mayoría de víctimas, por el otro, han dado lugar a una actitud si no de pasividad, sí de indiferencia, alimentada, además, por una cómoda percepción de estabilidad política y económica. (GMH, 2013, p. 14).

Posteriormente, se presenta la introducción del informe, que contextualiza cada caso a grandes rasgos, justifica su carácter emblemático y da cuenta del itinerario que guía la sucesión de los capítulos, mencionando también algunos aspectos metodológicos.

Independientemente del orden en que se presenten los capítulos, podemos identificar seis ejes siempre presentes en torno a los cuales se articula la información, lo cual es una constante en los casos emblemáticos tanto como en el informe general ;Basta ya! Estos ejes están articulados y entretejidos con las dimensiones orientadoras definidas desde el principio por el GMH que presentamos en el capítulo anterior, hechos, contextos y actores:

1. Lo descriptivo: narración de los acontecimientos con base en testimonios de testigos y sobrevivientes, relevamiento de prensa e indagación en archivos judiciales. Así comienzan la mayoría de los informes, lo cual es, a nuestro juicio, una manera de ubicar al lector ante los hechos que están por ser desmenuzados, puestos en relación con otros acontecimientos y examinados a la luz de los estragos que causaron en personas, comunidades y la sociedad colombiana como conjunto. Una forma típica de iniciar los informes es, por ejemplo la siguiente, tomada de La huella invisible de la guerra, sobre la Comuna 13 de la ciudad de Medellín:

El sábado 29 de junio de 2002, paramilitares del Bloque Cacique Nutibara (BCN) de las Autodefensas Unidas de Colombia (AUC) incursionaron en la parte alta del barrio El Salado, sectores 6 y 7, en la Comuna 13 de Medellín. Durante la incursión asesinaron a un habitante, incendiaron nueve ranchos, amenazaron maltrataron física y verbalmente a los residentes y forzaron el desplazamiento de aproximadamente 170 de las 200 familias que habitaban el sector. Las circunstancias en las que ocurrió este desplazamiento, las diversas formas de terror empleadas y las respuestas institucionales frente a su reconocimiento constituyen un caso ilustrativo de desplazamiento forzado en contextos urbanos.

En un solo párrafo el lector sabe ya qué hechos estarán en el centro del relato y cuál es la problemática asociada al conflicto que será tratada en relación con el caso.

2. Lo explicativo: interpretación que hace el $\mathrm{GMH}$ de las causas de los hechos estudiados con base en el análisis tanto de las narraciones como de los datos de prensa y archivo, los cuales son puestos en relación con investigaciones académicas 
y de organismos no gubernamentales, estudios históricos y sociológicos producidos por intelectuales y académicos de reconocida trayectoria en el abordaje del conflicto armado colombiano. Esta es una estrategia que aporta a la contextualización de los hechos y que sirve para que las interpretaciones cobren cierto equilibrio, pues no se refleja exclusivamente la posición del GMH sino que se muestran varias perspectivas y van evidenciándose los argumentos que llevan al Grupo a sostener una u otra lectura de los hechos. Ilustrativo de esto es el comienzo del segundo capítulo del informe Silenciar la democracia, el cual versa sobre las masacres de Remedios y Segovia, municipios antioqueños en los que se materializaron muchos de los asesinatos de miembros del partido de izquierda Unión Patriótica, hechos por los que han sido condenados reconocidos políticos de los partidos tradicionales, como César Pérez García, y ha sido imputada responsabilidad al Estado por parte de la Corte Interamericana de Derechos Humanos $^{76}$ :

Este capítulo se centra en los factores explicativos que permiten entender el por qué del protagonismo de los miembros de la Fuerza Pública dentro de las redes criminales que perpetraron las masacres entre 1982 y 1997, el por qué de la recurrencia al terror como estrategia de violencia en la guerra y las razones del ataque contra quienes hicieron parte de la movilización social y la acción política de la izquierda en la región.

Al respecto, $\mathrm{MH}$ considera que los factores explicativos de mayor incidencia son: a) el avance social y político de la izquierda en la región y el escalamiento de las acciones político-militares de la guerrilla, que fueron leídos por sectores radicales de las Fuerzas Militares como la materialización de la amenaza comunista y por sectores políticos tradicionales como amenaza para sus intereses; $b$ ) las condiciones político-ideológicas dentro de las Fuerzas Militares, en particular su representación de la amenaza comunista, y las tensiones entre el poder civil y el militar en el Estado central, las cuales le dieron margen de acción a los militares en la periferia para interpretar los acontecimientos nacionales como licencias para la acción; y c) las condiciones particulares de la construcción del Estado, su fragmentación territorial e institucional, y su articulación con una estructura social regional precariamente diferenciada, lo que condicionó la conformación de las redes criminales como un modelo particular de paramilitarismo. (GMH, 2010a, p. 125).

3. Las consecuencias en términos de daños: materiales e inmateriales, individuales y colectivos, psicosociales y morales, entre otros. Con el fin de crear una imagen de la envergadura de las afectaciones producidas por la confrontación armada, los informes son exhaustivos en la narración de los estragos. Testimonios desgarradores, recortes de prensa, reproducciones de panfletos amenazantes y fotografías elocuentes son los medios a través de los cuales el GMH vuelve al lector testigo de una serie de hechos atroces de los que probablemente poco o nada sabía antes de abrir cualquiera de sus libros. Para el Grupo, los daños hacen referencia a "un perjuicio, menoscabo o disminución que pone en condición inferior a aquel o aquello que lo recibe" (GMH, 2010, p. 88) y, más específicamente, los daños y sufrimientos son asumidos "como el resultado de procesos violentos que alcanzan a desestructurar redes y vínculos sociales, a la vez que rebasan los referentes, aprendizajes, sentidos y significados que son utilizados para afrontar los diferentes acontecimientos de la vida, afectando negativamente la dignidad humana" (GMH,

\footnotetext{
${ }^{76} \mathrm{Cf}$. http://www.colectivodeabogados.org/Corte-interamericana-condena-al
} 
Ibíd.). En un apartado posterior tendremos en cuenta algunas de las fotografías que acompañan el informe ¡Basta ya! Por ahora, uno de los cientos de testimonios recogidos en sus seis años de trabajo puede servir como muestra de la forma en que el GMH expone (en los múltiples sentidos de esa palabra) las heridas, pérdidas y sufrimientos de millares de colombianos en medio de la guerra:

"Ellos llegaban, se tomaban las casas y la gente se tenía que ir. Quién iba a llegar a decirles nada, ellos armados, quién iba a decir qué". Si la casa era del gusto de los combatientes, estos desalojaban a dueños y moradores: "Casas que les gustaban, lo iban sacando. A lo que les gustaban, ellos lo iban sacando". (GMH, 2013, p. 278).

Salí con mis siete hijos y cargaba otro en la barriga... A mi esposo lo mataron delante de nosotros. Salí sin mi esposo, sin tierra, sin ropa, sin dinero... isin nada!... Sola, con la cantidad de niños. Llegué a Montería a buscar cómo mantener estos niños, no podía dejarlos morir de hambre. No había tiempo para la tristeza, no había tiempo para nada. Tenía que buscar donde dormir, qué hacer para darles un pan y una aguadepanela a los niños. (GMH, 2013, p. 306).

Este testimonio evoca la declaración de Primo Levi en Si esto es un hombre, cuando dice que "además de no haber tiempo, ni siquiera hay espacio para tener miedo" (Levi, 1958 [2002], p. 76). En el caso de la mujer que tuvo que huir y que ahora habla, para lo que no hubo tiempo fue para la tristeza. Hay una fatalidad del mismo orden en ambos testimonios, como si quienes atraviesan por situaciones límite estuvieran condenados a tener una experiencia a tal punto abrumadora y apremiante que no hay lugar más que para experienciarla en toda su cruda manifestación y buscar la manera de sobrevivir a ella, sin que puedan mediar procesos psíquicos de nivel superior.

Entre las descripciones de las violaciones y de las masacres hay muchas que son crudas y desgarradoras, detallando punto por punto los vejámenes perpetrados bajo diversas y cuestionables "justificaciones":

[...] Una noche que íbamos con mi novio para mi casa, nos salió un grupo de nueve hombres. Se identificaron como paramilitares. A él lo amarraron y a mí me empezaron a desnudar a la fuerza y a golpearme muy duro $[\ldots]$ me decían que siempre iba a ser una prostituta de la guerrilla y me insultaban, me decían cosas horribles. A él también le decían que era guerrillero, que por eso andaba conmigo. Después de estar desnuda, empezaron uno por uno a penetrarme, todos me golpeaban la cara, arrancaron mi cabello, me metieron sus penes por la boca y en un momento empezaron a meterme sus pistolas en mi vagina [...] Después de que cada uno hizo conmigo lo que se le ocurrió, me llenaron de arena y piedras en mi vagina y me dijeron que yo nunca me iba a olvidar de ellos. Que me iban a dejar viva solo para que recordara que nunca debía meterme con guerrilleros. Que todo eso me pasaba por guerrillera, por ser una prostituta cochina. (GMH, 2013, p. 308).

4. Las consecuencias en términos judiciales: qué se ha investigado y dejado de investigar, magnitud de la impunidad, condenas proferidas, causas prescritas. A nuestro parecer, la importancia que se le otorga a este asunto tiene que ver con la paradoja, señalada por el mismo GMH en el ¡Basta ya!, entre la sólida tradición de la jurisprudencia colombiana y la extrema impunidad que ha rodeado los crímenes asociados al conflicto armado, entre otros. Pensar la memoria sin la justicia -según han enseñado los movimientos de reivindicación de los derechos humanos 
alrededor del mundo- pareciera no tener sentido, menos en contextos de violencia política en los que el Estado ha sido uno de los actores centrales, por acción y por omisión. En el capítulo titulado Guerra y justicia en la sociedad colombiana del informe ¡Basta ya!, el Grupo reconoce las paradojas, límites y logros de la justicia en años recientes:

[...] es indudable que en la historia reciente del país la justicia ha tenido impactos históricamente diferenciados sobre la dinámica del conflicto armado. A través de cambios en los criterios de judicialización (¿cuál es el marco con que se juzga?) y los patrones efectivos de juzgamiento (¿cómo y a quiénes se juzga efectivamente?), la justicia ha generado incentivos que contribuyen, o bien a reproducir el conflicto armado (ejemplo de ello es la alta impunidad en relación con delitos de alto impacto cometidos en zonas de conflicto armado, que hace que allí la probabilidad de castigo sea muy baja y que por lo tanto un buen número de personas opte por la ilegalidad), o bien a detener algunas de sus dinámicas, como es el caso de las investigaciones judiciales de las alianzas entre políticos y paramilitares llevadas a cabo por la Corte Suprema de Justicia, orientadas entre otras cosas a poner fin a uno de los engranajes que explican la larga duración de la guerra. (GMH, 2013, p. 198).

5. Las memorias: qué se hace para recordar, quiénes han promovido y consolidado procesos de memoria, quiénes participan, qué significados se transmiten. Aunque lo esperable sería que las memorias fueran las protagonistas absolutas de la producción de un grupo de memoria histórica y que no hiciera falta en cada informe un capítulo aparte dedicado a ellas, esta decisión del GMH les imprime una fuerza particular. En todos los otros ejes es perceptible la voz de víctimas y sobrevivientes, sus recuerdos son tomados en cuenta como fuente que se contextualiza, pero el apartado sobre las memorias recoge, más que los recuerdos puntuales sobre determinados hechos, las iniciativas individuales y colectivas que han sido llevadas a cabo para preservarlos del olvido, hacer notorias las identidades de las víctimas, restablecer los tejidos resquebrajados y hacer intentos por superar el sufrimiento padecido en compañía de otros. Es el espacio por excelencia en el que GMH muestra las acciones que los llevaron a definir el ejercicio de la memoria como un acto de resistencia y de dignificación. El capítulo quinto, llamado Las memorias: la voz de los sobrevivientes, dan cuenta de esta lógica:

Los capítulos anteriores describieron el escenario de eventos y repertorios de violencia sobre los que en este capítulo interviene el trabajo creativo y humano del recordar y narrar lo vivido frente a graves violaciones de derechos humanos. La exploración del contenido de estas memorias, de sus énfasis narrativos e interpretativos, y del significado que tienen para quienes cuentan sus experiencias, constituye el método mediante el cual nos acercamos a comprender quiénes son las víctimas del conflicto armado en Colombia.

El capítulo muestra cómo estas memorias se organizan alrededor de tres ejes: 1) un eje narrativo que registra el horizonte del dolor y de la crueldad humana desde el que los testigos y sobrevivientes recuerdan lo que pasó; 2) un eje interpretativo que ubica a la complicidad y el estigma como memorias emblemáticas desde las que las víctimas explican los orígenes y las causas del conflicto armado en su territorio, o sea, el por qué pasó lo que pasó; y c) un eje de sentido que registra las respuestas y recursos de las personas frente a la violencia armada con sus numerosos actos de protección, solidaridad, rescate, desobediencia y resistencia directa e indirecta. 
6. Las recomendaciones: estrategias puntuales y llamados a autoridades, instituciones y sociedad civil para involucrarse y comprometerse activamente en el reconocimiento de los hechos atroces derivados del conflicto, comprenderlos y construir las condiciones de posibilidad de la no repetición. En un intento porque sus indagaciones y hallazgos no se queden en un informe que cuenta las cosas como fueron y como son, el GMH culmina cada uno de sus textos con un apartado de recomendaciones que van desde llamados generales a la necesidad ética del reconocimiento de las víctimas y el conocimiento de la historia, hasta la delimitación de acciones específicas que podrían llevarse a cabo por autoridades locales y nacionales para disminuir los índices de impunidad, acompañar de manera más efectiva los procesos de reparación económica y simbólica y, en fin, elaborar una política pública que prepare al país para la transición hacia la paz y restituya efectivamente los derechos de las víctimas a la verdad, la justicia y la reparación.

El ¡Basta ya! mantiene esta misma estructura básica, aunque incorpora también un capítulo inicial con las cifras del conflicto, el cual ha sido ampliamente difundido por medios nacionales e internacionales, tal vez porque condensa de una manera llamativa e inapelable la magnitud de los efectos del conflicto.

\subsubsection{De la comprensión a la esperanza: estructura del informe ¡Basta ya!}

¡Basta ya! Colombia: memorias de guerra y dignidad es el título del informe general sobre el conflicto, producto con el que el GMH da cumplimiento al mandato legal que signó su creación y funge, a la vez, como un informe bisagra en la transición del Grupo al Centro de Memoria Histórica. Su publicación estuvo ajustada a los plazos concebidos desde un principio, que suponían una existencia de 8 años (contados desde mediados de 2005) para la CNRR y todas sus áreas. En cuanto al título, Mauricio Builes relató que inicialmente era únicamente Memorias de guerra y dignidad, pero que tras varias conversaciones en el Grupo se consideró la conveniencia de incluir la palabra "Colombia" en el título, puesto que de otro modo los potenciales lectores no identificarían cuáles eran las memorias que se encontraban allí condensadas. Así pues, el título iba a ser Colombia: memorias de guerra y dignidad, y con él se diagramó la portada y era el citado en toda la extensión del texto. Sin embargo, un día antes de que saliera para imprenta, Gonzalo Sánchez escribió al equipo a cargo del informe diciendo que era necesario incluir además una frase contundente que tuviera un impacto inmediato sobre el lector y generara un efecto de recordación e identificación del informe. Junto con esta argumentación, propuso que dicha frase fuera ¡Basta ya!, un llamado que reconoce que la guerra y el conflicto aún persisten, pero que indica un agotamiento y un pedido de suspensión que vendría a representar la voz de las víctimas y de la sociedad colombiana. Su propuesta fue acogida por el Grupo y, a juicio de Mauricio Builes, a casi seis meses de publicado en informe (en enero de 2014), es indudable que se trató de una decisión acertada, pues efectivamente ha habido un posicionamiento del informe bajo la rúbrica del ¡Basta ya!

En el prólogo al mismo, Gonzalo Sánchez lo describe de la siguiente manera:

Este informe no es una narrativa sobre un pasado remoto, sino sobre una realidad anclada en nuestro presente. Es un relato que se aparta explícitamente, por convicción y por mandato legal, de la idea de una memoria oficial del conflicto armado. Lejos de pretender erigirse en un corpus de verdades cerradas, quiere ser elemento de reflexión para un debate social y político abierto. El país está pendiente de construir una memoria legítima, que no consensuada, en la cual se incorporen explícitamente las 
diferencias, los contradictores, sus posturas y sus responsabilidades y, además, se reconozca a las víctimas.

Aquí vemos condensada la posición del GMH en varios niveles: dice qué es y qué no es el informe, justifica por qué, realza la estrecha relación entre convicción -de los investigadores- y mandato legal. Asume de entrada qué es lo que pretende ser, señala cómo uno de sus objetivos fundamentales es la interpelación a la sociedad colombiana para la realización de un debate social y político que, a juicio del Grupo, los ciudadanos están en mora de dar. Por último, y en consonancia con la centralidad otorgada a la resistencia de las comunidades (otro aspecto que es palpable en los títulos de los informes y que estuvo en el centro de las elaboraciones del GMH desde el comienzo mismo de sus actividades), se resalta el potencial de empoderamiento que tiene la memoria como articuladora de las experiencias de víctimas y sobrevivientes en todo el país. Es evidente en esta presentación una afinidad entre la posición del GMH y las elaboraciones propias del campo de estudios de la memoria, que otorga especial importancia a las luchas políticas por la misma y reconoce, por no decir que exhorta (en el caso específico de Jelin) a los historiadores e intelectuales a asumir su responsabilidad política y ética de manera crítica, especialmente en estos tiempos, en que "las narrativas oficiales son escritas por historiadores profesionales". (Jelin, 2002, p. 41).

Con base en todos estos elementos, se sitúa al lector desde el comienzo en un escenario particular en el que reconocimiento y responsabilidad serán elementos articuladores de un debate amplio que tiene como pretensión un efecto de sacudida en la sociedad colombiana, de tal suerte que aquello que no ha querido ser visto o asumido en su abrumadora dimensión se haga visible de un modo en que ya no sea tan sencillo para quien lo lee mirar para otro lado, como si la realidad de la que se habla nada tuviera que ver con él.

Uno de los presupuestos éticos de los que parten y que se señala en forma de imperativo es que "El país está pendiente de construir una memoria legítima, que no consensuada, en la cual se incorporen explícitamente las diferencias, los contradictores, sus posturas y sus responsabilidades, y, además, se reconozca a las víctimas" (GMH, 2013, p. 16). Los autores del ¡Basta ya! pretenden aportar a esta construcción dando legitimidad a sus elaboraciones justamente a partir de la pluralidad de perspectivas que incluyen y que busca hacer énfasis una y otra vez en la complejidad del conflicto y la intrincada red de causas y efectos que han permitido su surgimiento y perpetuación. Reconociendo la dificultad de un consenso en torno a la memoria del conflicto, le apuestan a presentar un panorama amplio que sirva, más que como palabra final acerca de lo sucedido, como un punto de partida para un debate público y amplio, enunciado dentro de sus propósitos desde el principio.

A la hora de describir qué es lo que hace el informe, se afirma en la introducción: que "revela la enorme magnitud, ferocidad y degradación de la guerra librada, y las graves consecuencias e impactos sobre la población civil" (GMH, 2013, p. 19). El verbo con el que se describe lo que hace el informe, además de ser formulado de manera contundente, como hecho, y no como algo que se pretende lograr (lo que da cuenta de una pretensión de verdad justamente "revelada"), deja entrever también la posición del GMH en cuanto a su labor y misión: descubrir lo que ha sido ignorado o ha estado oculto para la sociedad colombiana como conjunto. Llaman también la atención las resonancias bíblicas de una palabra como revelación, que evoca las ocasiones en que dios, a través de sueños o enviados angelicales, manifiesta a los hombres verdades desconocidas o eventos del futuro. Esta observación aparentemente superflua, cobra sentido en el contexto de un país profundamente religioso, además de que hay en varios de los informes cierta recurrencia a 
metáforas bíblicas que hacen pensar que no se trata de una mera casualidad (por ejemplo, Memorias del éxodo en la guerra).

El primer capítulo del informe, uno de los que más eco mediático ha tenido, se ocupa de manera minuciosa de las cifras del conflicto, mostrando un saldo de los afectados por distintos tipos de victimización: asesinato, secuestro, desaparición, desplazamiento, indicando las modalidades más empleadas por cada uno de los actores armados. Mediante gráficos estadísticos, fotografías y testimonios, se realiza un mapa de la barbarie y la degradación de la guerra que impacta al lector y lo enfrenta con datos contundentes, recabados en diferentes bases de datos, pero que aclaran que se trata de una mera aproximación, puesto que hay un gran subregistro de los delitos que permite suponer que las cifras presentadas, aunque escalofriantes, no son un reflejo preciso de lo que ha sucedido.

Otra de las estrategias usadas en este primer capítulo es la comparación del caso colombiano con otros en el mundo y en América Latina, con lo que se busca hacer una suerte de demostración empírica de que la prolongación del conflicto armado y sus consecuencias mantienen al país como uno de los más violentos del mundo, independientemente de que sus habitantes, especialmente aquellos que habitan en los centros urbanos, no lo perciban de esta manera. Respecto al conflicto armado interno, se afirma, por ejemplo, que "Colombia en el país con el conflicto sin negociar más antiguo del mundo", dato tomado del Anuario de procesos de paz 2012 (Fisas y Escola de Cultura de Pau, 2012). En cuanto a las víctimas de desaparición forzada, señalan:

\begin{abstract}
El Registro Nacional de Desaparecidos reportó, hasta noviembre del 2011, 50.891 casos, de los cuales se presume que 16.907 corresponden a desapariciones forzadas, mientras que el Registro Único de Víctimas registra 25.007 personas desaparecidas forzosamente como producto del conflicto armado. Esta elevada magnitud solo puede comprenderse cuando se constata que tal delito rebasa lo ocurrido en las dictaduras militares del cono sur de América Latina: 485 desapariciones forzadas en Paraguay entre 1958 y 1988; 979 en Chile entre 1973 y 1990; y cerca de 9.000 en Argentina durante la dictadura militar entre 1976 y 1983. Pese a las dimensiones de la desaparición forzada en Colombia, el nivel de reconocimiento social y público de este delito es muy bajo si se lo compara con otras modalidades de violencia. (GMH, 2013, p. 58).
\end{abstract}

El inicio del ¡Basta ya!, incluyendo el prólogo (a cargo de Gonzalo Sánchez), la introducción (escrita por Martha Nubia Bello, coordinadora del informe) y el primer capítulo (titulado Una guerra prolongada y degradada. Dimensiones y modalidades de la violencia) apela a provocar un impacto en el lector, ubicándolo primero como parte de una sociedad y un Estado que no está por fuera de la guerra y, después, poniendo ante él una colección de hechos y cifras que evidencian la crueldad y degradación de la guerra y el conflicto con el que se acostumbró a vivir el país. Es un abrebocas que genera asombro, en el que se esbozan apenas algunas interpretaciones y se emplean breves testimonios, convocando al lector para que continúe recorriendo el informe y, poco a poco, vaya descubriendo la historia que desembocó en tan dramáticas estadísticas.

El segundo capítulo, Los orígenes y las dinámicas del conflicto armado, es el que da respuesta concreta al mandato legal por el que fue creado el $\mathrm{GMH}$, aunque modificado, como hemos insistido, al referirse abiertamente al conflicto armado, y no meramente al origen y evolución de los grupos armados ilegales. Allí, el Grupo hace un trabajo analítico e interpretativo en el que señala cuatro períodos importantes en la historia del conflicto: 
- 1958-1982: Transición de la violencia partidista a la violencia subversiva, período caracterizado por la proliferación de guerrillas en diferentes regiones del país, por la movilización social y por la marginalidad del conflicto armado, en tanto se presentaba fundamentalmente en territorio rural. Llama la atención que, pese a que en el desarrollo del capítulo se da cuenta de la creación de grupos paramilitares con autorización del Estado a mediados de los años sesenta, no se haga en principio ninguna mención de este hecho en la descripción de este momento.

- $\quad$ 1982-1996: El GMH no da una descripción sintética de este periodo, quizá porque incluye un número tan amplio de hechos que aumentaron la dimensión y actores del conflicto armado, que es difícil de clasificar. Entre los hechos que distinguen estos años, resaltan: la proyección política, expansión territorial y fortalecimiento militar de las guerrillas, el surgimiento de grupos paramilitares (los cuales habían aparecido en décadas anteriores), la crisis y el colapso parcial del Estado, la irrupción y propagación del narcotráfico, el auge y declive de la guerra fría, el posicionamiento del narcotráfico en la agenda global, la firma de una nueva constitución (1991), una serie de procesos de negociación con algunos grupos armados y reformas democráticas con resultados parciales y ambiguos.

- 1996-2005: Recrudecimiento del conflicto armado, período en el que destacan los siguientes hechos: expansión simultánea de grupos guerrilleros y paramilitares, crisis y recomposición del Estado en medio del conflicto, radicalización política de la opinión pública en favor de una salida militar al conflicto, incremento de la influencia del narcotráfico y el terrorismo en la dinámica del conflicto.

- 2005-2012: Reacomodo del conflicto armado, caracterizado por: la ofensiva militar del Estado (que alcanzó su máximo grado de eficacia en la acción contra las guerrillas), fracaso de la negociación política con los grupos paramilitares y, en consecuencia, rearme de sus estructuras, con una mayor influencia del narcotráfico y un actitud más desafiante frente al Estado.

Además de esta, presentan también otra periodización que es distinta pero afín a ella, y que detalla con mayor precisión la intensidad de la violencia característica de cada momento:

- Tendencia decreciente (1958-1964): transición de la violencia partidista a la subversión.

- Violencia baja y estable (1965 a 1981): irrupción de las guerrillas y confrontación con el Estado.

- Violencia creciente (1982-1995): expansión de las guerrillas, irrupción de grupos paramilitares, propagación del narcotráfico, reformas democráticas y crisis del Estado.

- Tendencia explosiva (1996-2002): “... como consecuencia del fortalecimiento militar de las guerrillas, la expansión nacional de los grupos paramilitares, la crisis del Estado, la crisis económica..." (GMH, 2013, p. 33).

Otro aspecto importante de la interpretación presentada por $\mathrm{GMH}$ en este capítulo es sus concepción de los actores armados ilegales, "[...] no sólo como aparatos de guerra, sino especialmente como productos sociales y políticos del devenir de nuestra configuración histórica como país" (GMH, 2013, p. 16), en la que vuelve a ponerse de manifiesto la apuesta por una lectura política y estructural del conflicto colombiano que, a su vez, justifica las recomendaciones no sólo para buscar salidas negociadas del mismo sino para que el Estado haga cuanto esté a su alcance para hacerle frente a la inequidad, la falta de garantías electorales, los despojos de tierras y, en general, a todos los factores que han servido de justificación y alimento para el surgimiento y perpetuación del conflicto armado. Estos son agrupados por el GMH en tres grandes categorías que engloban las lógicas amplias de la guerra: control de territorio y despojo de tierras, dominio político electoral y apropiación de recursos legales o ilegales. 
El capítulo tres, dedicado a la relación entre guerra y justicia devela una crisis profunda y continuada en el sistema judicial, que ha hecho de la impunidad el sello característico del tratamiento del conflicto y que ha minado la confianza de víctimas y ciudadanos en la capacidad del Estado para protegerlos y hacer valer sus derechos. Aunque en Colombia ha tendido a existir una relativa independencia de la rama judicial que ha hecho que en algunos casos pueda poner límites a posiciones arbitrarias del Estado en cuanto a la administración de penas y sanciones (por ejemplo en el caso del juzgamiento a militares), hay también una debilidad arraigada en el sistema judicial que ha desembocado en grandes dosis de impunidad. Para GMH, la

[...] histórica debilidad de la justicia — debida algunas veces a la precariedad de sus recursos investigativos, otras a las condiciones de seguridad en las que trabajan sus funcionarios y otras más a prácticas corruptas que desvían al aparato judicial del cumplimiento de sus funciones- la condena a tener graves problemas de eficacia de cara a los múltiples desafíos que plantea una guerra degradada como la nuestra. Las altísimas cifras en materia de impunidad y la enorme variedad de mecanismos de impunidad documentados por el GMH en relación con delitos de gran impacto como son las graves violaciones a los Derechos Humanos y las infracciones al Derecho Internacional Humanitario cometidas en el contexto del conflicto armado interno colombiano ilustran la precariedad del aparato judicial en materia de eficacia (GMH, 2013, p.197).

Pese a que la impunidad sea una constante en los reclamos de víctimas y sobrevivientes, no sería ecuánime referirse sólo a este aspecto de la justicia, no sólo porque así como hay funcionarios corruptos o temerosos, los hay también que han arriesgado su propia integridad con el fin de esclarecer diferentes actuaciones de los actores del conflicto (tanto legales como ilegales); sino también porque el análisis de la justicia debe ir más allá de lo que sucede en los juzgados e incluir la tradición del derecho que ha primado en el país y las acciones de los organismos que estudian, avalan, vetan o profieren sentencias que establecen las directrices bajo las cuales deben regirse las diferentes investigaciones y actuaciones de organismos jurídicos y administrativos, tales como la Corte Suprema de Justicia o la Corte Constitucional.

La forma en que se encuentra estructurado el capítulo evidencia un interés del GMH por mostrar y desatacar las continuidades y transformaciones en la operación de la justicia que se han dado a partir de 1971. Una de las principales continuidades es, por ejemplo, el tratamiento especial para los miembros de la fuerza pública (especialmente el ejército) que han cometido delitos que exceden los requerimientos de su labor, pero que se han amparado en ella para evitar ser investigados y juzgados, al alegar que los cometieron en cumplimiento de su deber. La existencia de un fuero penal militar ha supuesto una constante tensión entre las fuerzas armadas y las altas cortes, y ha sido uno de los mayores focos de críticas internacionales al tratamiento del conflicto por parte del Estado colombiano, pues se ha usado el argumento de la lucha contra la subversión para justificar violaciones a los derechos humanos. El capítulo hace un recorrido minucioso por los vaivenes de esta relación y se sitúa del lado de quienes desconfían de la aplicación del fuero porque hay material probatorio suficiente que demuestra que las investigaciones y castigos no prosperan cuando están a cargo de los propios militares.

Otro punto importante en relación con el estado actual del conflicto y los procesos de negociación es el capítulo de la justicia transicional, el cual arrancó en el año 2005 con la Ley de justicia y paz y ha resurgido con el planteamiento del Marco jurídico para La Paz, propuesto por el gobierno Santos para sustentar las conversaciones de paz con las Farc que 
se están adelantando desde el 2012 en La Habana. Ambas han recibido críticas por parte de organismos de derechos humanos nacionales e internacionales porque, a su juicio, promueven la impunidad y dejan a las víctimas sin posibilidades reales de conocimiento de la verdad y acceso a las reparaciones materiales y simbólicas a las que tendrían derecho bajo la justicia ordinaria. Sin embargo, dada la magnitud del conflicto armado y los largos años de impunidad acumulados, hay en la actualidad un desbordamiento de la capacidad de los entes judiciales para investigar la totalidad de los casos que aún no han sido esclarecidos, a los que hay que sumarles los que se siguen presentando en la actualidad. Para el GMH, a partir de 1992, este desbordamiento ha sido patente debido a los "altísimos niveles de violencia, ampliamente superiores a los registrados en cualquier otro momento de nuestra guerra" (GMH, 2013, p. 200). Esto justifica la postura transicional o relativista para el juzgamiento de los hechos que, apelando a la imposibilidad empírica de investigarlo todo, propone una clasificación y agrupación de los crímenes que haga que al menos una parte de estos puedan ser investigados y castigados.

El capítulo 4, titulado Los impactos y los daños causados por el conflicto armado en Colombia, es el más cargado emocionalmente de todos y el que apela con mayor intensidad a la memoria literal, basada en testimonios de víctimas, testigos y sobrevivientes, con un alto componente descriptivo de situaciones y sentimientos desgarradores, aunque siempre acompañados de algún análisis de contexto o teórico que llevan al lector más allá de la empatía, no mediante la explicación de cifras, lógicas internas de la guerra o procesos judiciales, como en los capítulos anteriores, sino apelando a señalamientos éticos y a interpretaciones de carácter psicológico y social que dan cuenta de las consecuencias de la guerra en los planos subjetivo y comunitario. Pese a tratarse de un capítulo difícil de leer, por la crudeza y la barbarie de los relatos allí presentados, su ubicación dentro del informe es una muestra del interés del GMH por hacer trascender la mera compasión hacia las víctimas, puesto que antes de poner de manifiesto los horrores de la guerra en hechos concretos, se realizó un panorama de sus dimensiones generales, se estableció un mapa de actores, eventos y prácticas, se historizó el origen y la evolución del conflicto y se resaltaron los tortuosos alcances y muchas limitaciones del sistema judicial para hacerle frente a un fenómeno con muchas cabezas que ha crecido descomunalmente, en parte por manejos errados de parte de distintos gobiernos, por la influencia y permeabilidad del narcotráfico en muchas esferas de la sociedad, por la precariedad de nuestra democracia, pero también porque los ciudadanos del país se han acostumbrado a la ignominia o le han dado la espalda a aquello que no los afecta de manera directa.

El capítulo final, Memorias: la voz de los sobrevivientes, vuelve a dar centralidad al aspecto de la resistencia y lo emparenta con la dignidad, haciendo coherente un relato que se presenta justamente como una condensación de las memorias de guerra y dignidad de un país entero que ha sido recorrido de norte a sur por el sufrimiento y la estigmatización, pero también por la reivindicación de los derechos y las luchas por escapar de la indiferencia. Así, el GMH organiza este capítulo con base en varios tipos de memoria: memoria del sufrimiento, de la estigmatización, de la desolación, de la complicidad y, nuevamente con testimonios, ilustra la capacidad que han tenido personas y comunidades afectadas por la violencia para sobreponerse a sus tragedias y para construir nuevas formas de vida, bien en sus lugares de origen, bien en los sitios a los que fueron llegando luego de haber escapado de allí. Este capítulo pone una vez más de manifiesto la tendencia del GMH a ordenar sus relatos yendo de lo particular a lo general, dejando para el final aquello que, a nuestro parecer, consideran esencial en términos éticos y que, por lo mismo, busca ser transmitido de una forma coherente, paso a paso, dejando una suerte de lección al culminarse la lectura de cada parte del texto. El capítulo quinto tiene tal función dentro del informe y en él, a su 
vez, el último de los apartados viene a reflejar, con una clara intencionalidad, las labores de la dignidad y la resistencia:

Los testimonios que se incluyen en este aparte describen cómo sobrevivieron y qué hicieron las víctimas frente a las violencias que sufrieron o de las que fueron testigos. En ellos, cuentan cómo actuaron para intentar protegerse, modificar, negociar o alterar las situaciones de violencia que vivieron y los designios de los actores armados. [...]

Los relatos rescatan a las víctimas y testigos como seres humanos que, por encima del desbalance de poder frente a los actores armados, responden a situaciones adversas y buscan alterar sus resultados. De esta manera, los testimonios acopiados por el GMH reivindican el sentido político y la función reparadora que estas acciones tienen para sobrevivientes y testigos. En algunos casos, las memorias de estos actos dan cuenta también de los juicios y posiciones morales y políticas de estas personas.

El registro de estos actos de pervivencia, rescate y resistencia en medio del conflicto armado en Colombia es visto por quienes los narran como un deber fundamental en la construcción de la memoria histórica sobre la guerra. La sociedad necesita saber lo que pasó. Esto quiere decir que es preciso mantener el registro de la devastación y explorar el por qué pasó, pero también el cómo se afrontó y se resistió. Estas historias no son necesariamente memorias victoriosas, sino, más bien, memorias que, al reconstruir a las víctimas y las comunidades como sujetos y colectivos que perviven, responden y resisten, cumplen un papel de dignificación e igualmente de reconocimiento de sus verdades narrativas.

\subsubsection{Retórica de las imágenes: un discurso paralelo y silencioso}

No sólo de palabras está hecha la memoria. Desde que Didi-Huberman (2004) publicara su famoso Imágenes pese a todo, quedó en evidencia que muchas veces unas cuantas fotografías de hechos atroces de los que no se quería saber o a los que no se quería dar crédito, son suficientes para generar un efecto de verdad inapelable, de cosa que no puede ya ser negada bajo la excusa de lo inimaginable.

Los informes del GMH, y en particular el ¡Basta ya!, están acompañados de numerosas imágenes, casi siempre en blanco y negro, casi siempre en planos generales, casi siempre sin mayores comentarios que su mera descripción y la indicación de quién fue el fotógrafo. Estas imágenes son una especie de discurso paralelo y silencioso que se va dejando a lo largo de los textos para que quien lee, además, vea. Cuando la mirada ya no recae solamente sobre columnas de palabras y de frases sino que se topa con imágenes enormes, muchas veces de una página entera, no hay escapatoria. Ahí están los muertos, los charcos de sangre (que se distinguen con nitidez pese a la deliberada ausencia del rojo), los niños armados, el llanto de hombres y mujeres, la desolación de un caserío abandonado, las marchas con muchas o pocas personas, los familiares de los desaparecidos sosteniendo como en todo el mundo- sus fotografías con la esperanza de que alguien los haya visto vivos, los huesos exhumados que cierran de tajo esa esperanza que se tuvo.

Apelar a las imágenes es apuntar a un registro distinto de la subjetividad del lector para reconstruir la memoria de otra manera. Es posible que las elaboradas explicaciones que culminan casi siempre con matizaciones y preguntas, sean olvidadas por el gran público. También que algunos testimonios, tal vez por su componente emocional, sean fragmentariamente evocados cuando el lector se encuentre ante determinadas situaciones 
o noticias. Pero las imágenes quizá pueden imprimirse con mayor intensidad en la memoria, porque así, silenciosas como son, pueden ser más contundentes para comprender -en un sentido hermenéutico- los estragos del conflicto armado sobre el que el GMH está intentando sensibilizar a la sociedad. Aunque dicha sensibilización sea apenas un primer paso y no alcance para propiciar reflexiones y toma de posturas, es una estrategia inteligente para comenzar.

Allí donde Didi-Huberman opone la astucia de la imagen contra la razón de la historia (2004, p. 45), el GMH los une para potenciar el efecto de sus relatos: no hay ya contra sino simplemente con, en su sentido más obvio: dos cosas que van juntas o que aparecen a la vez. La concomitancia de imagen y palabra y, en algunos casos, la irrupción de imágenes que ocupan todo el espacio disponible desplazando por un breve lapso a las palabras, viene nuevamente a confirmar lo que Didi-Huberman dijera:

[...] en cada producción testimonial, en cada acto de memoria los dos -el lenguaje y la imagen- son absolutamente solidarios y no dejan de intercambiar sus carencias recíprocas: una imagen acude allí donde parece fallar la palabra; a menudo una palabra acude allí donde parece fallar la imaginación.

A continuación reproducimos algunas de las imágenes que acompañan los cinco capítulos del ¡Basta ya! para mostrar de qué manera hay también en ellas un relato que va de los hechos "objetivamente" documentados a la dimensión de resistencia y dignidad, pasando por la literalidad de los momentos victimizantes: 
Capítulo 1: Dimensiones y modalidades de la violencia

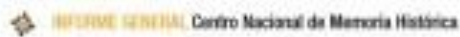

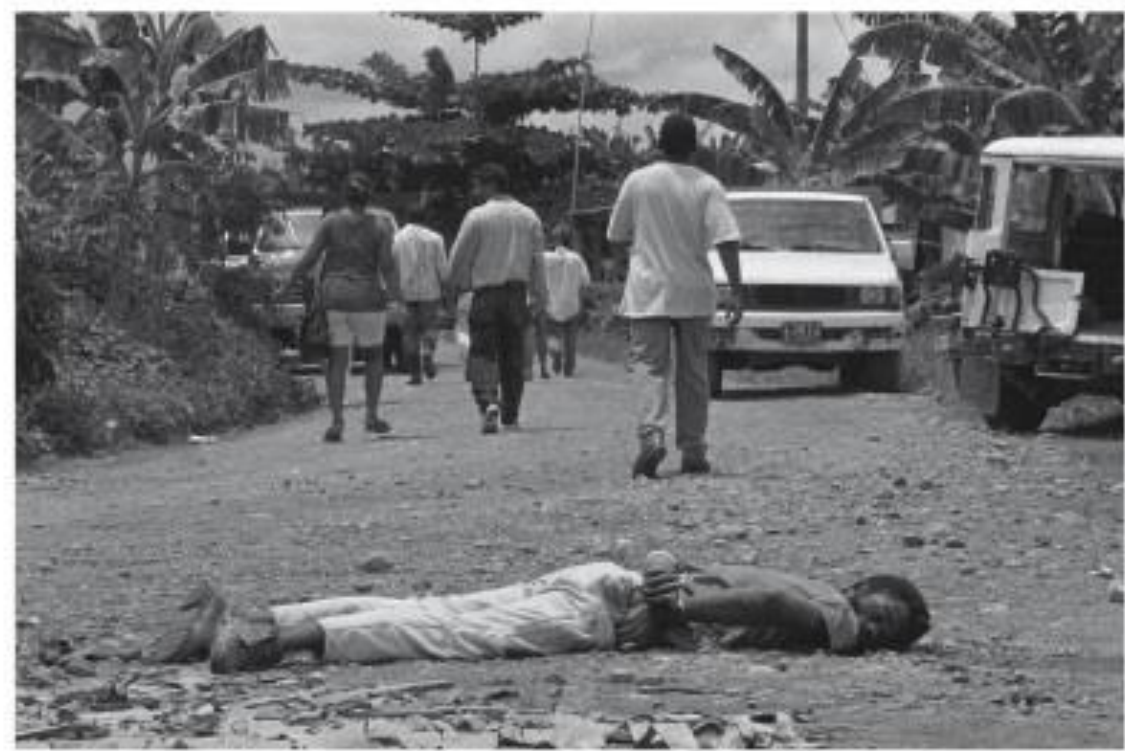

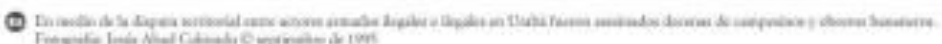

Una guerra prolongada y degradada.Dimensiones y modalidades de violencia

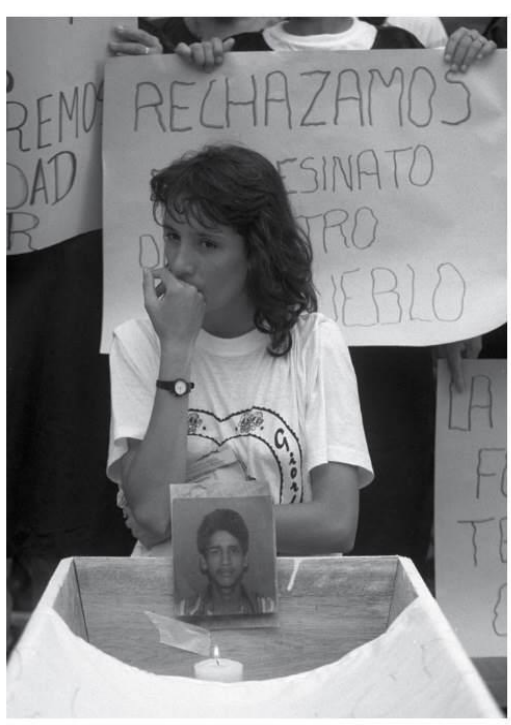

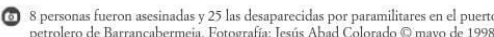

-ţ̦- INFORME gEnERAL Centro Nacional de Memoria Histórica

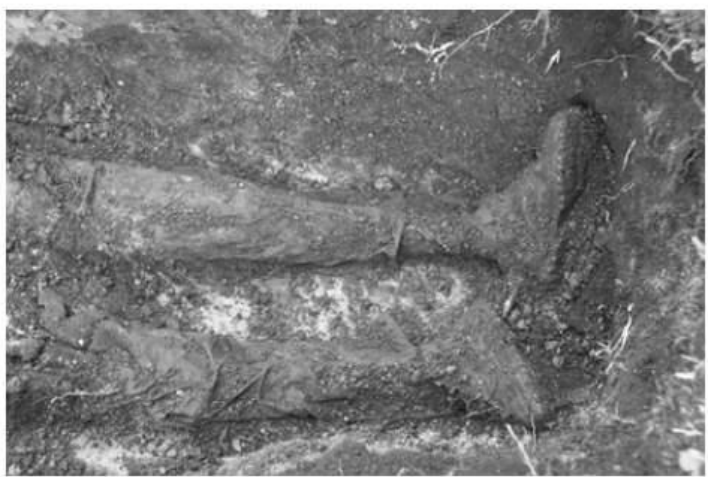

(2) Exhumaciones en el municipio de Granada - Antioquia.

Fotografía: Jesús Abad Colorado (9 2007

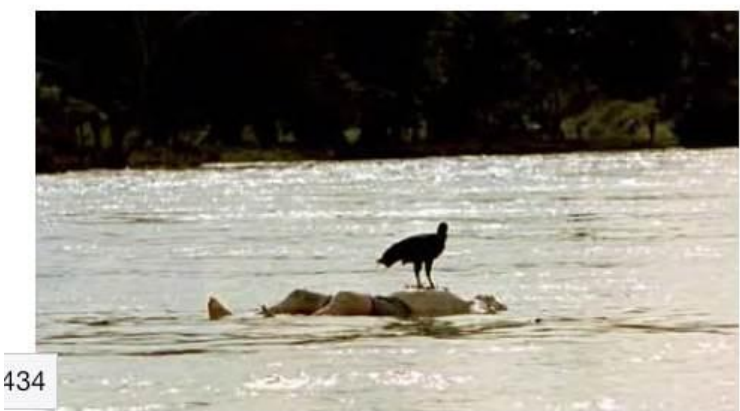

(2) Rio Cauca, Tumbas de agua. Fotografía: Manuel Saldarriaga

El Colombiano @ 2002 


\section{Capitulo 2: Los orígenes, las dinámicas y el crecimiento del conflicto armado}

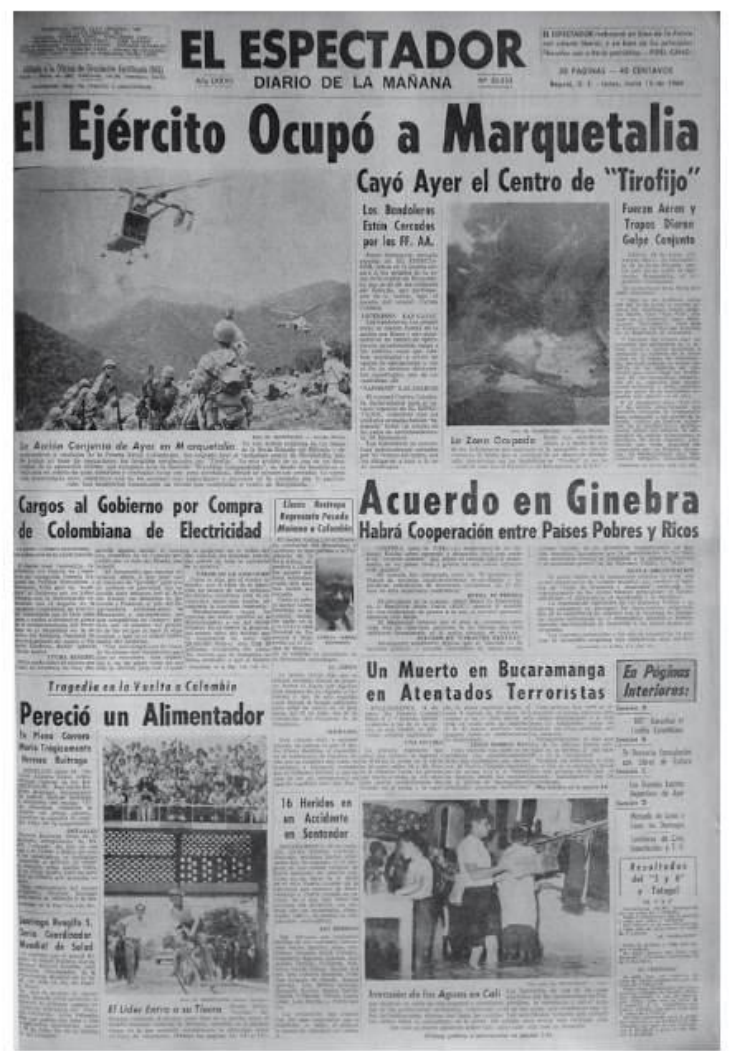

(6) Reporte de prensa de El Espectador, 15 de junio de 1965
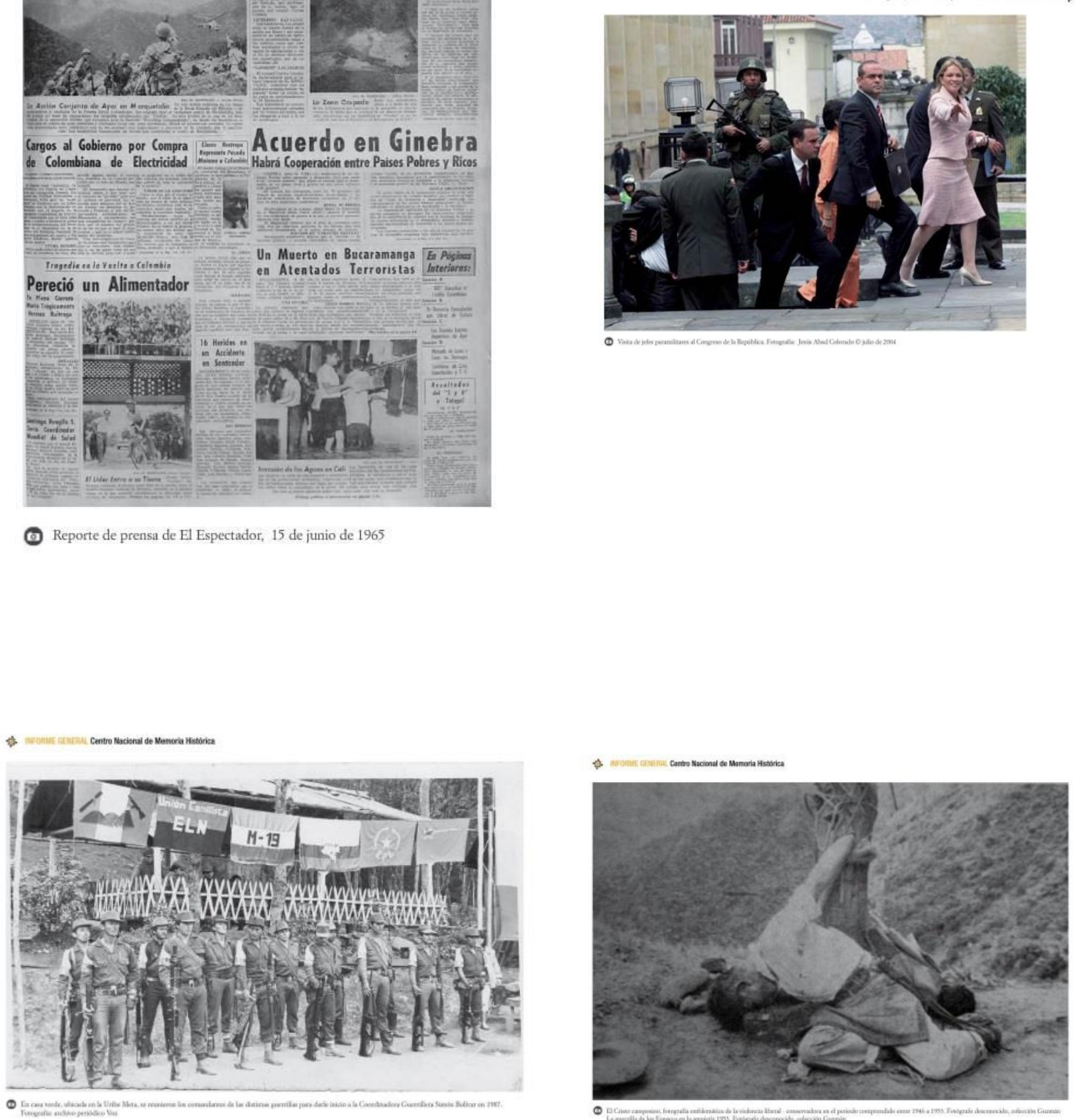

○) 
Capítulo 3: Guerra y justicia en la sociedad colombiana

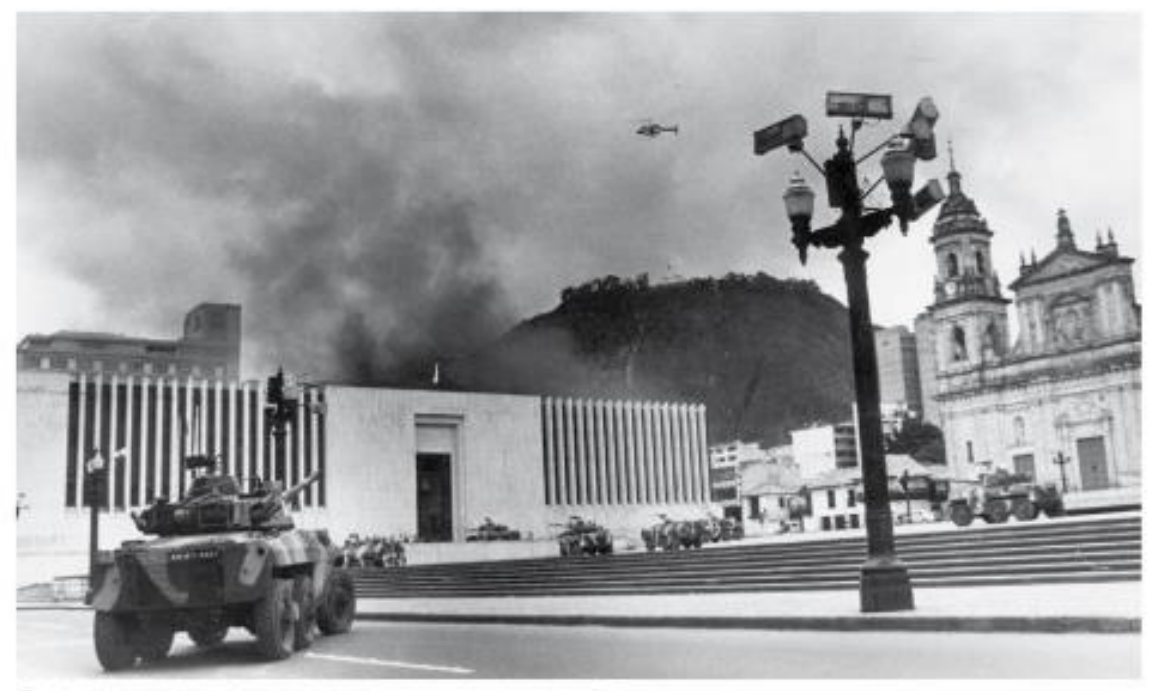

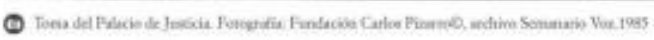
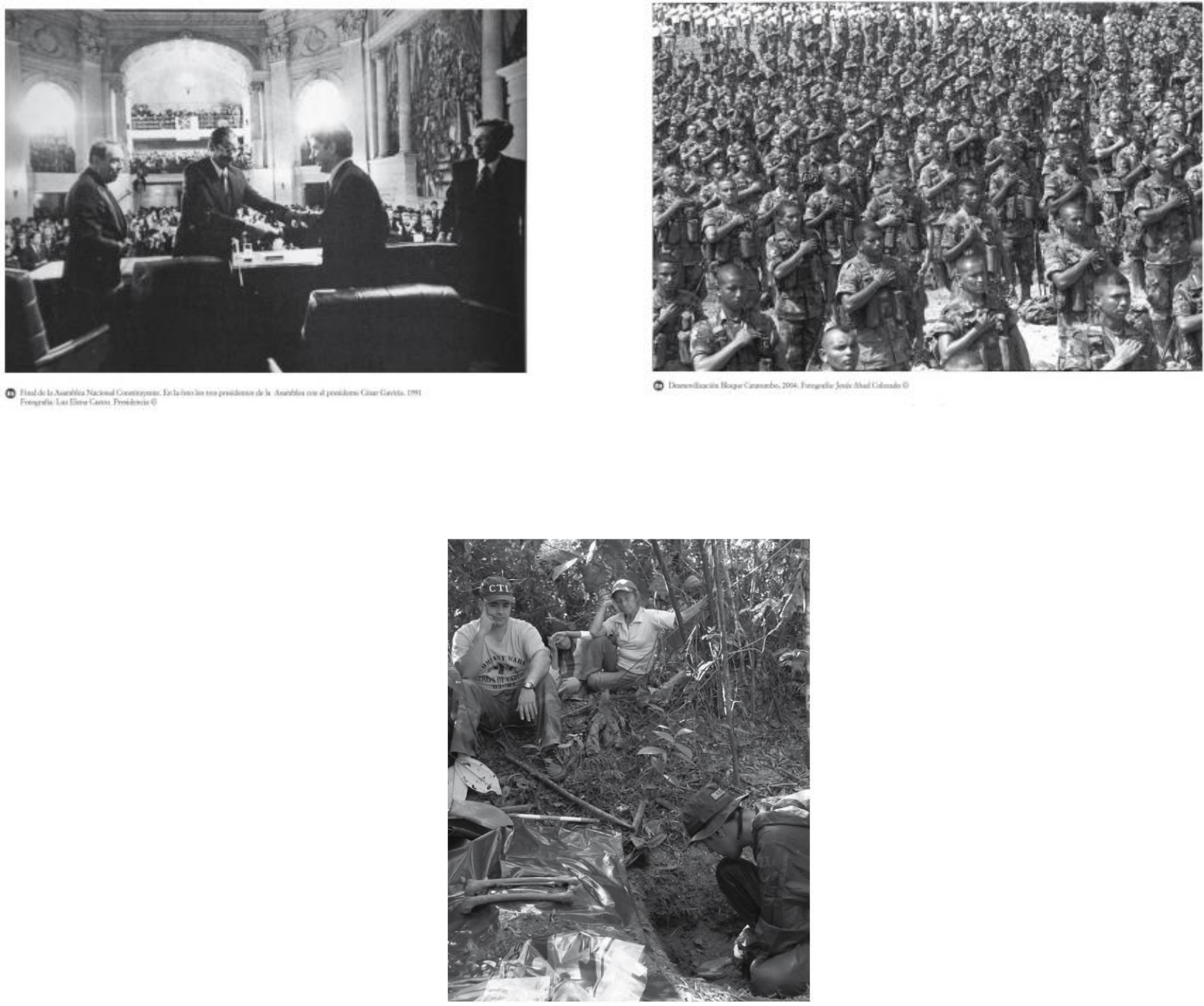

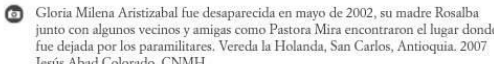


Capítulo 4: Los impactos y los daños causados por el conflicto armado
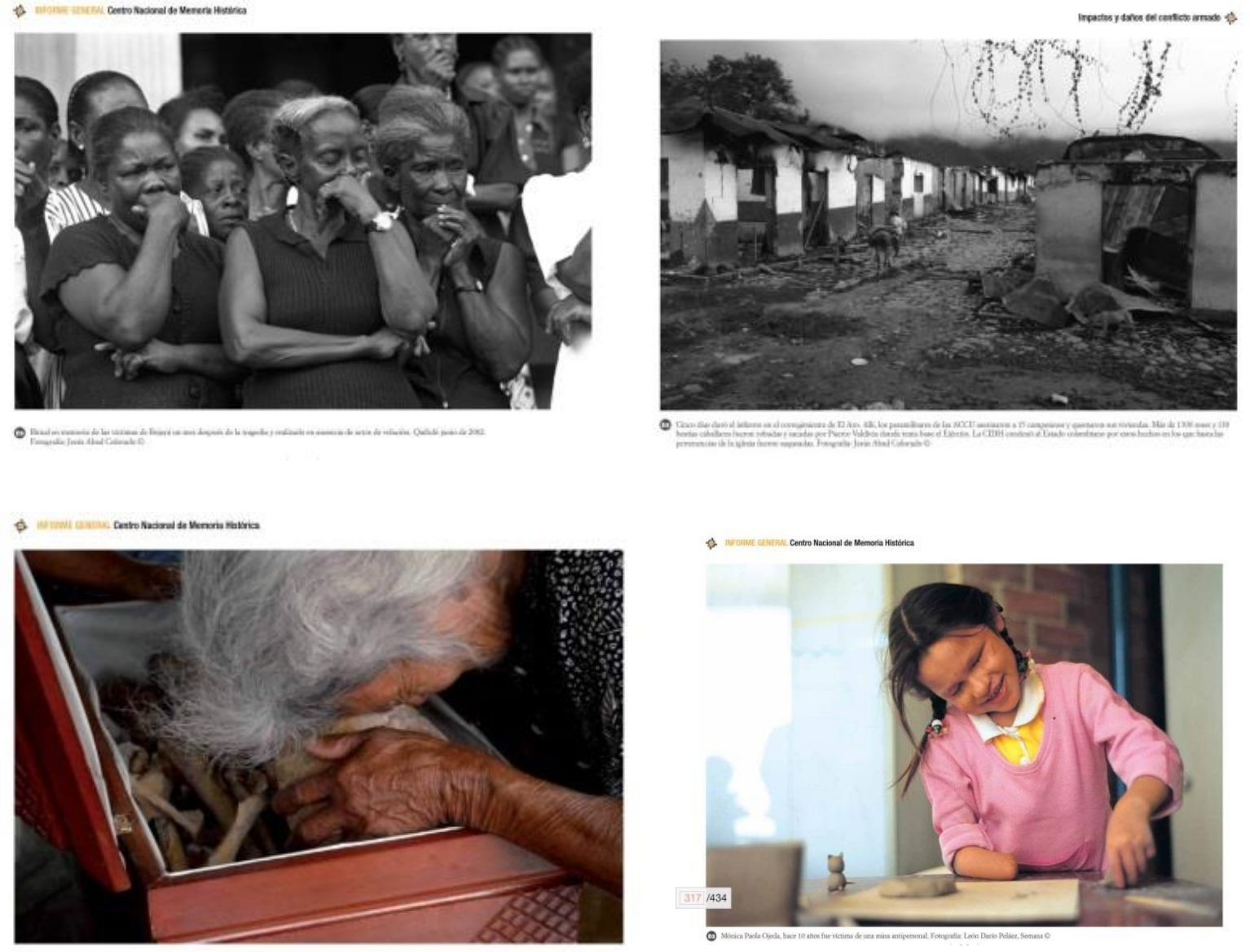

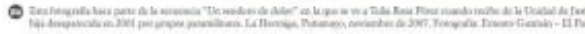

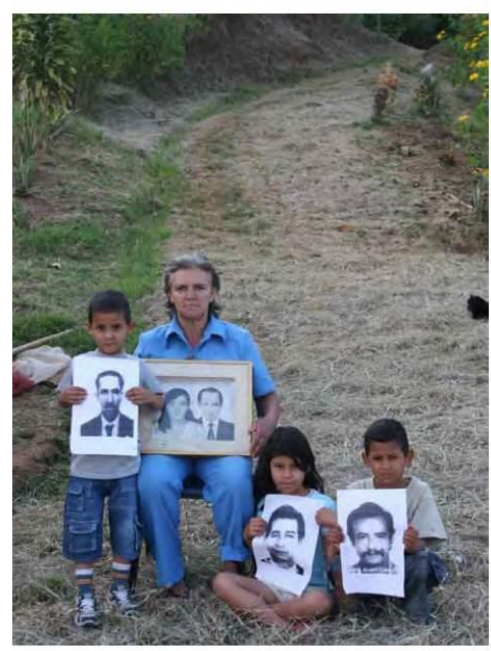
(7) Doña Maria Valencia Cano perdióa a su esposo y y dos cuñados en una acción
del cejercito y los paramilitines en Truijlo, Valle del Cauca. Su sucgro murió de

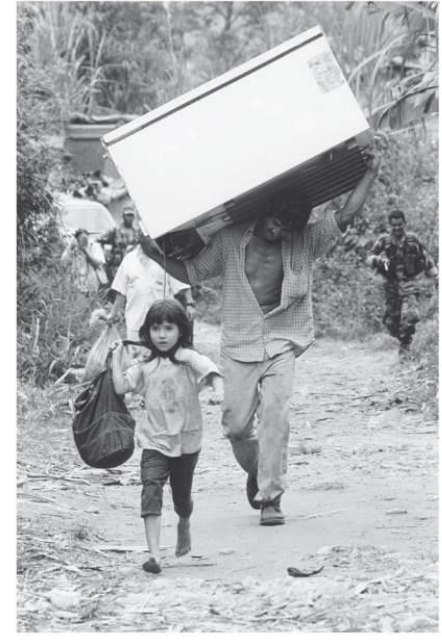

En enero de 2003 , tras la masscre de 17 personas, efectuada por la guerrilla de
las FARC en las veredas de Dos Quebradas, Dinumarca y la Tupiada, Karina, su familiti y los demás pobladores de estas veredas, se vi-
sus hogares. Fotografiai: Jesús Abad Colorado $\odot 2003$

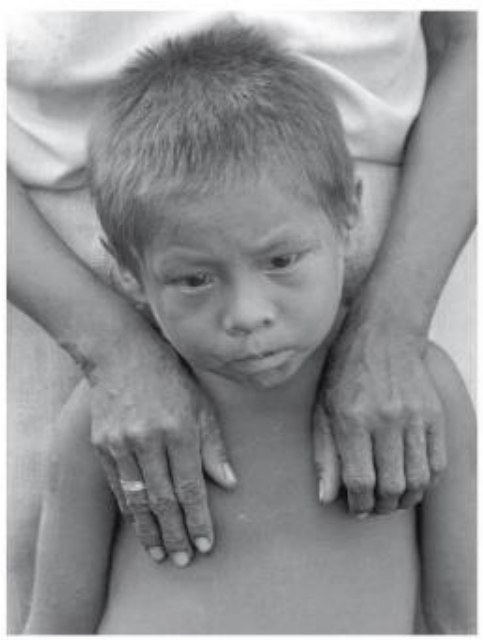

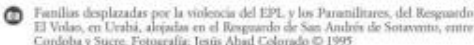




\section{Capítulo 5: Memorias. La voz de los sobrevivientes}
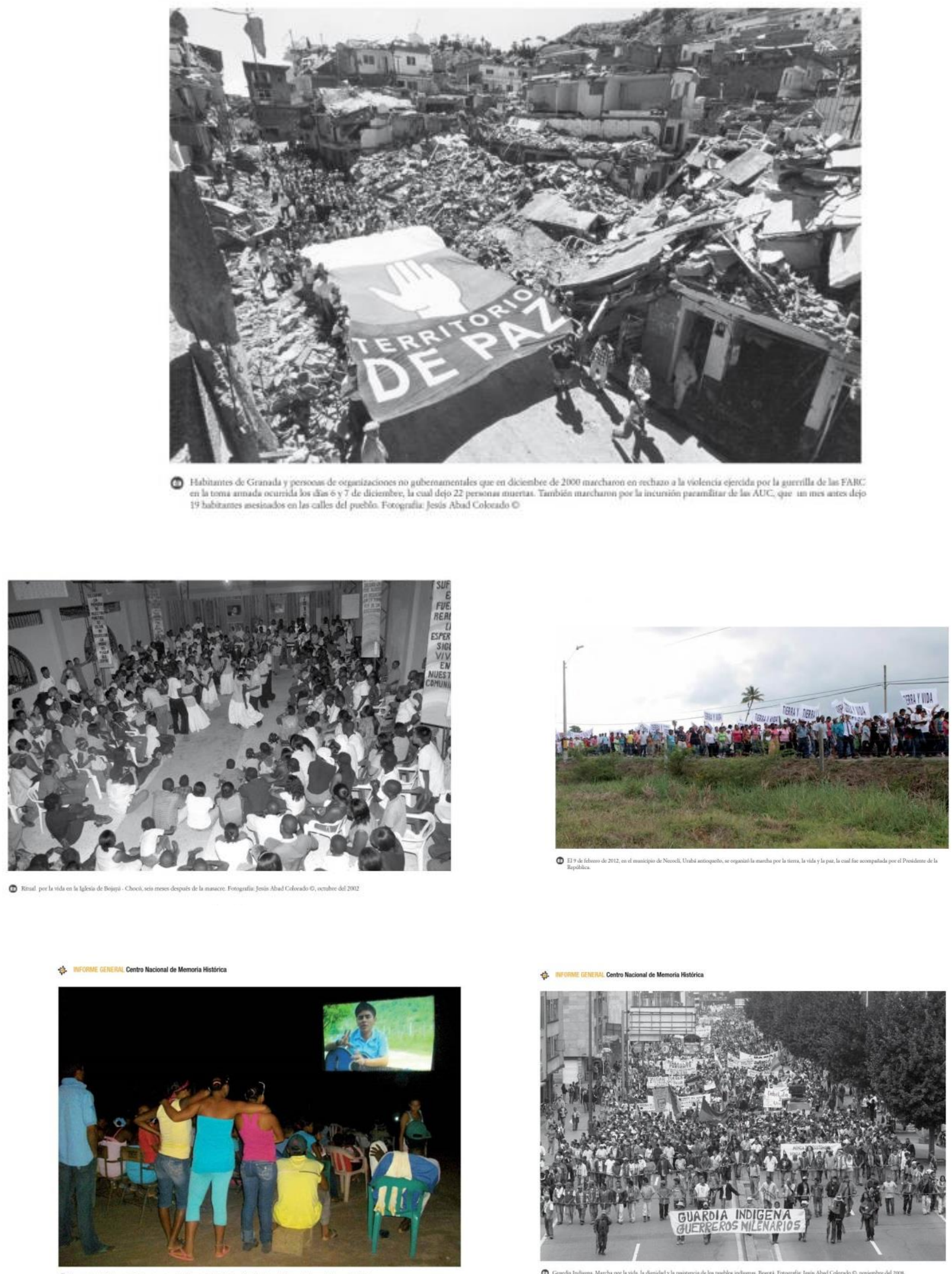
Las portadas de los informes también parecen revelar una intencionalidad: todas los correspondientes a casos emblemáticos y análisis temáticos (excepto el del caso del municipio de El Tigre) están compuestas en un fondo negro sobre el que se sitúa una imagen en blanco y negro (las evocaciones del luto son evidentes) mientras que el título resalta en letras amarillas en la parte superior de la fotografía. Los textos metodológicos tienen todos una carátula de color claro (blanco o amarillo) mientras el único que hasta el momento se ocupa de temas de reintegración es de color granate.
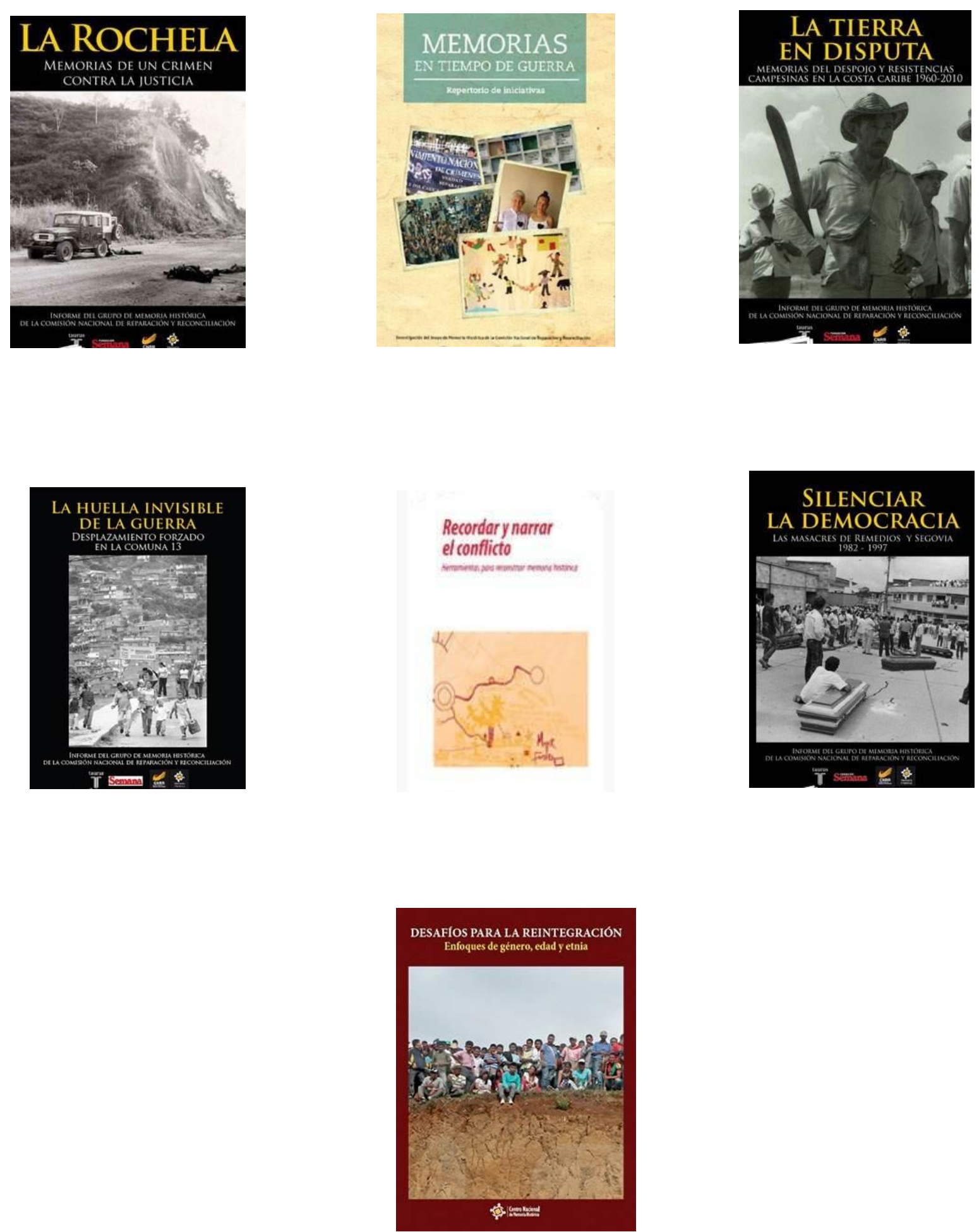


\subsection{Toda apuesta tiene su costo: alcances y límites de las propuestas de sentido del GMH}

De la revisión de los informes de GMH se desprende que no es necesariamente la falta de memoria el principal problema respecto de los hechos violentos asociados al conflicto. Al menos no en el nivel individual y local, pues hay evidencia suficiente de que en las comunidades son numerosas, interesantes y creativas las estrategias y acciones de los sobrevivientes y familiares para recordar a sus muertos, para tener presente los vejámenes que han sufrido. Si de memoria colectiva se trata, hay que decir que no está ausente, al menos localmente. Sin embargo, se trata de colectividades pequeñas y muchas veces aisladas, lo cual, como señala Huyssen (2001, p. 23), se convierte en un obstáculo a la hora de construir algo como una memoria nacional, en tanto las sociedades son cada vez más fragmentarias.

Lo que hay de nacional en Colombia es otra cosa, hastío tal vez, exceso de estudios y de explicaciones, de diagnósticos que se repiten en el tiempo, de recomendaciones que los gobiernos piden pero poco escuchan. $Y$ en la sociedad, una especie de represión que lleva a que sean muchos los que prefieren no saber nada de eso, pese a que tienen pleno conocimiento de que viven en un país en conflicto armado. Contra esta especie de amnesia o ignorancia voluntaria y masiva, el GMH levanta sus investigaciones, sus documentales, sus construcciones diversas en un intento continuado y persistente por hacer visible, audible y sobre todo legible (en su doble sentido de lo que puede ser leído pero también comprendido) una historia del conflicto contada fundamentalmente desde la subjetividades de víctimas, testigos y sobrevivientes, pero anclada también en datos concretos, cifras y sentencias que recubren de veracidad los acontecimientos narrados. Amparo Sánchez ${ }^{77}$, investigadora de la Corporación Región, quien participó en la elaboración del informe sobre la Comuna 13 de Medellín, considera que ese apartado que el GMH incluye siempre y en primer lugar sobre "los hechos", es un sello distintivo de su labor que lo diferencia de lo que acostumbra hacerse en los trabajos orientados desde las ciencias sociales en investigaciones con comunidades victimizadas, en los que se privilegia justamente su subjetividad, casi siempre sin recurso a los datos empíricos. A su juicio, esto le da otro tipo de legitimidad a los relatos y es válido incluirlo en producciones de carácter estatal. La concatenación de fuentes que realiza el GMH y la forma en que articula los apartados de los informes dejan traslucir la búsqueda de hacer un "legítimo uso público de la historia" (Habermas, 2000, p. 47), en el que se interpela a la sociedad no como responsable colectiva de la perpetuación de la confrontación armada, pero sí como un agente que juega un papel más activo que el que ha estado dispuesta a reconocer. Las "imputaciones explicativas" -al decir de Habermas- que aparecen en los informes están orientadas más a fomentar una autocompresión ético-política de los ciudadanos que a proferir condenas morales o establecer verdades judiciales.

Para Herrera y Cristancho (2013, p. 190), el quehacer del GMH se relaciona con dos planos: el ético-político, que "reivindica la versión de las víctimas y el deber de recordarlas" y el epistemológico, que abarca la "pretensión historiadora que exige reconstruir y explicar objetivamente unos hechos (verdad histórica) bajos los presupuestos de la historia como disciplina". Hay aquí en juego una tensión en el GMH que, a pesar de que procura concatenar los dos polos que la sostienen, termina por jugarse a favor del imperativo éticopolítico, lo cual ha sido la base de una de las principales críticas que desde el ámbito

\footnotetext{
77 En entrevista personal realizada en febrero del 2014 en la ciudad de Medellín.
} 
académico se le han hecho a su producción. La apuesta por un deber ser, por la asunción de valores democráticos, por la posibilidad de una reconciliación nacional que no sea un simple borrón y cuenta nueva, es problematizada desde los saberes que han estudiado los efectos nocivos que pueden derivarse de la imposición de una manera de ser o, en este caso, de recordar. Tanto Jaramillo como Herrera y Cristancho escriben en un tono de escepticismo sobre las apuestas de sentido que está postulando y materializando el $\mathrm{GMH}$, pues su carácter estatal hace que sean las principales candidatas a tener una circulación masiva en el ámbito nacional, si bien hasta el momento no hay ningún dictamen legal que obligue a las instituciones educativas a hacer uso de sus informes para la enseñanza de la historia de Colombia.

Builes y otros miembros del GMH son conscientes de que su carácter estatal es el principal foco de críticas a su labor, puesto que esto los hace automáticamente portadores de un discurso oficial, se postule o no se postule este en términos de verdad. Que sus productos sean tomados como verdades no depende de los investigadores, pues como ocurre con todo aquello que se publica o difunde, es imposible controlar las formas de recepción y las interpretaciones que se harán con base en lo expresado. Sin embargo, justamente el estar advertidos de que la palabra del GMH "tiene la fuerza de la palabra del Estado" (Sánchez, 2011, p. 162), hace que sean sumamente cuidadosos con la forma en que estructuran sus relatos. En una de las muchas entrevistas concedidas como coordinador del GMH, Sánchez (2011) indicó que es cada vez más frecuente que los informes internacionales, por ejemplo de la Corte Interamericana de Derechos Humanos, tomen en cuenta las elaboraciones del $\mathrm{GMH}$ como una palabra de Estado que fundamente el reconocimiento de responsabilidades. Por estas razones, afirma, "debemos tener muchísima cautela con lo que se dice, cómo se dice y con qué se fundamenta" (Sánchez, entrevistado por Jaramillo, 2011b, p. 162).

Si de responsabilidad estatal se trata encontramos una resonancia con los conceptos de responsabilidad legal y responsabilidad política que son usados tanto por Arendt como por Jaspers para referirse tanto a las consecuencias que le caben a un individuo por sus actos según las leyes del colectivo al cual pertenece, como aquellas que recaen sobre un Estado en cuanto tal, como representante de una nación, garante de los derechos de los ciudadanos y autoridad que rige la existencia social de los mismos.

En el caso que nos ocupa, es la responsabilidad política la que viene a ocupar un lugar central y para evaluar sus alcances es importante tener en cuenta el lugar que se le otorga a la responsabilidad moral y a la legal en las políticas de memoria. La primera -la responsabilidad moral- si bien no puede imponerse porque su instancia es la propia conciencia del individuo, sí puede ser promovida por el Estado, no sólo mediante políticas de memoria, sino también desde las políticas educativas y la responsabilidad social. Los relatos del $\mathrm{GMH}$ apelan constantemente a este tipo de moralidad cuando interpelan y cuestionan la posición de apatía e indiferencia que han asumido muchos colombianos que no se han visto afectados directamente por el conflicto armado ni están en contacto cotidiano con las víctimas del mismo. En cuanto a la responsabilidad legal, el GMH ha tomado en cuenta los tipos de condenas que se han impuesto a los actores del conflicto armado, el lugar de indultos, rebajas de pena u otros beneficios y los efectos legales y simbólicos de este tipo de medidas sobre el conjunto de la sociedad civil, los cuales, como vimos anteriormente, han dejado en general una sensación de impunidad y de injusticia. La voz de Jaspers vuelve a ser contundente para resaltar que la responsabilidad política va en doble vía, puesto que "la culpa política implica responsabilidad de todos los ciudadanos por las consecuencias de las acciones estatales", en la medida que 
Las faltas morales son el fundamento de estados de cosas en los que crecen la culpa política y el crimen. La comisión de pequeños pero numerosos actos de negligencia, de cómoda adaptación, de fútil justificación de lo injusto, de imperceptible fomento de lo injusto; la participación en el surgimiento de la atmósfera pública que propaga la confusión y que, como tal, hace posible la maldad, todo esto tiene consecuencias que condicionan la culpa política por los estados de cosas y los acontecimientos (Jaspers, 1998, p. 53).

Recapitulando algunos elementos ya esbozados, podemos hacer varias afirmaciones: en primer lugar, que los referentes del GMH están a tono con el discurso global en torno a la memoria. Autores como Todorov, Anderson, Jelin, Bobbio, Vena Daas, o las directrices de la $\mathrm{CIDH}$, la CPJ, Amnistía Internacional, entre otros organismos internacionales, sirven de telón de fondo para explicar y justificar tanto la importancia de la memoria como el lugar central otorgado a los testimonios de las víctimas, que se vuelven objeto de estudio a la vez que fuente privilegiada de conocimiento. Así, sus interpretaciones están alineadas no tanto (o no sólo) a un discurso oficial en términos estatales sino a cierta suerte de oficialidad occidental que, continuando con los imperativos éticos abiertos por la experiencia del Holocausto nazi (Huyssen, 2001), han hecho de la memoria de hechos traumáticas una responsabilidad de la humanidad toda, como única garantía de que esos hechos atroces que han evidenciado la magnitud de barbarie de la que somos capaces como especie no se repitan o, por lo menos, no queden impunes y silenciados, sin consecuencias de ninguna clase.

Desde el punto de vista ético, político y normativo, el sentido del discurso del GMH hace una apuesta por los valores ideales que deberían sustentar todo Estado de derecho, tales como la libertad, la autonomía, la dignidad e igualdad humana, orientados todos ellos a la articulación de un lazo social en el que las diferencias puedan ser expresadas sin temores y exista la posibilidad de que cada quien despliegue su ser sin atentar o menoscabar las libertades y derechos de los otros ni imponerse violentamente sobre los intereses comunitarios (Zorrilla, 1995). Por estas razones, son justamente aquellos cuyas libertades y dignidad han sido mancilladas por los distintos actores armados quienes van a cobrar protagonismo en la reconstrucción de la historia del conflicto emprendida por el GMH:

[...] el grupo decide autodenominarse Grupo de Memoria Histórica. Esta autodenominación tiene que ver con el significado que el equipo otorga al mandato que recibe, pues, en lugar de restringirse a la reconstrucción de la Historia en Singular -que podría entenderse como un ejercicio en pos de hechos, estructuras y datos duros-, opta por otorgarle un lugar central a la agencia expresada en las memorias de los actores del conflicto, sobre todo las de las víctimas. De allí que para el grupo la labor de aproximarse al pasado no esté guiada sólo por el esfuerzo de conocer, con rigor académico, las condiciones sociales, económicas, políticas e institucionales que hicieron posible los engranajes de la guerra y la violación masiva de derechos en Colombia, sino que también está orientada por el afán de comprender, registrar y dignificar la manera como las víctimas recuerdan, sufren, interpretan y resisten resignificando lo vivido, tanto individual como colectivamente. En este sentido, para el equipo las memorias son una opción imprescindible para reconstruir la historia. (GMH, 2011c, p. 52).

Su posicionamiento ético y la apuesta clara y reiterada por poner en el centro la palabra de las víctimas, aunque siempre articulada a los contextos de acaecimiento de cada uno de los hechos narrados, así como a su lugar en la dinámica compleja del conflicto a lo largo de los años, hacen que sea muy difícil encontrar interpretaciones simples y maniqueas que puedan ser tomadas como verdad o explicación cerrada acerca de las causas y consecuencias del conflicto. Lejos de la caracterización que Franco y Levin (2007, pp. 13-14) hacen de la historia 
de circulación masiva o de divulgación como aquella que "ofrece relatos accesibles, narrativamente atractivos y basados en modelos explicativos simples, nítidos, generalmente monocausales y teleológicos [...]", las narraciones del GMH tienen la voluntad manifiesta de reflejar un panorama de conflictivas e intrincadas relaciones entre la legalidad y la ilegalidad, la sociedad y los actores armados, las instituciones estatales y las fuerzas que han buscado minarlas o cooptarlas para mostrar que no hay una sola explicación posible de lo que ha acontecido -y persiste- en Colombia.

Quizá por esto, aunque los críticos empiecen por advertir los riesgos indudables que han corrido los intelectuales que decidieron hacer parte del proyecto memorialístico del Estado, terminan por reconocer en su labor unas características que lo hacen relevante para las construcciones de futuro que podrán llegar a gestarse en el país, si bien no son garantía de éxito de la apuesta democratizadora. Jaramillo, por ejemplo, dice:

[...] más allá de todas las críticas reales y potenciales que puedan hacerse a $\mathrm{MH}$, es innegable por el ejercicio comparativo que hemos desplegado en esta tesis, que por primera vez en Colombia, surge una preocupación institucional oficial por recuperar la memoria de esta guerra, priorizando las voces de las víctimas, sus relatos, sus lecturas del país y sus apuestas de futuro. Lo interesante a mediano y largo plazo sería poder conjugar la memoria emblemática que están reconstruyendo estos activistas teóricos con una memoria pública ensamblada por los ciudadanos. (Jaramillo, 2011, p. 400).

Por su parte, Herrera y Cristancho concluirán que

[...] las producciones del GMH dan luces para pensar en procesos de formación política que se han dado en virtud de tramitaciones colectivas sin que intervenga la institución escolar, pero en las que median disputas por la adscripción a proyectos preestablecidos (partidos ya existentes o colectivos ya configurados) o la creación de nuevas posibilidades de reclamación social. Además, sus producciones dejan claro que el papel de la violencia política perpetrada por los actores armados no sólo dejó secuelas psicológicas en las víctimas, sino secuelas políticas, pues implicó una formación política que destruyó los tejidos sociales y las apuestas ya configuradas. Por otro lado, la labor reconstructiva que emprende $\mathrm{MH}$, y ahora $\mathrm{CMH}$, se constituye en un importante escenario para seguir pensando en los procesos de subjetivación política en el país, con el color que implica que su lugar de enunciación sean las políticas de la memoria estatales que propenden a visibilizar a las víctimas y reconocer lo que ha pasado, situación que puede conllevar el riesgo de sepultar en un pasado sin referente en el presente unos proyectos políticos que ya no pueden repararse y que quizás políticamente no se esté interesado en reconstruirlos. Es cierto que $\mathrm{MH}$ se esfuerza por reconceptualizar la noción de víctima como un sujeto activamente político. Pero eso no cierra la cuestión de si esta labor acentuará la construcción social de la memoria y de la identidad nacional desde la violencia y el conflicto armado, y si hará posibles nuevas maneras de participación social. (Herrera y Cristancho, 2013, p. 206).

Nuestra postura es coincidente con la de los investigadores citados en cuanto a la importancia de mantener una postura crítica y escéptica frente a las posibilidades abiertas por los informes, pues su sola publicación y la difusión que han comenzado a tener -en especial el ¡Basta ya! - no son condición suficiente para que se produzca en la sociedad una transformación tan profunda como la que se plantea idealmente. Ni su difusión masiva en forma de memoria pública, ni el acercamiento de sus elaboraciones al gran público en formatos más accesibles como los documentales, revistas o versiones resumidas que han 
empezado a circular y que se sumarán a otras estrategias de difusión ${ }^{78}$. Como el mismo GMH plantea, hacen falta profundas transformaciones institucionales, contextuales, formales e informales para que se geste un ambiente nacional propicio para la reconstrucción de un tejido social tan hondamente afectado. Sin embargo, su mera existencia y los procesos de diálogo entablados en los últimos años con actores armados son expresión de una nueva voluntad política que, aunque con contradicciones, está abriendo un horizonte político y simbólico susceptible de desencadenar otras formas de vérselas con la realidad -ahora inapelable- del conflicto armado. Amparo Sánchez, quien ha trabajado con comunidades victimizadas por alrededor de dos décadas y que, como ya se señaló, participó en la elaboración de uno de los informes del GMH, expresó en una entrevista personal que "el país no sería lo mismo si no tuviera el ¡Basta ya!", pues con él se rompió el silencio en torno a las víctimas, se asumió el reto de hacer memoria en medio del conflicto ( $y$, en esa medida, fue posible escuchar voces que de otra manera hubieran quedado definitivamente silenciadas, pues en una confrontación tan prolongada las personas, aunque hayan sobrevivido a actos violentos, empiezan a morir por enfermedad o vejez), se prepararon nuevos gestores de memoria y, desde su perspectiva, se abre la posibilidad de continuar con otro capítulo en el largo y tortuoso camino hacia un país sin conflicto armado.

Uno de los rasgos más novedosos y también significativos del trabajo del GMH fue su metodología inductiva, que lo llevó a ocuparse primero de casos puntuales en las diferentes regiones del país para luego mostrar en un informe general, de carácter nacional, las regularidades del conflicto, aunque sin desconocer las particularidades. La precariedad de la democracia, la amenaza constante a la justicia y la institucionalidad, se hacen palpables en todos los informes; del mismo modo que la constante disputa por los territorios con los consecuentes desplazamientos masivos, despojos, amenazas, muertes.

El trabajo adelantado hasta el momento por el GMH está enfocado casi por completo al asunto del conflicto armado, la reconstrucción de los hechos, la difusión de los testimonios, entre otras labores. Para el cumplimiento de su mandato ha hecho un fuerte énfasis en la dimensión de la resistencia de las poblaciones, las experiencias de solidaridad, recuperación, retorno y reestructuración de los tejidos desgarrados por los hechos violentos, y hay aquí una veta interesante y fundamental para continuar realizando procesos constructivos con las comunidades. Es un lugar común afirmar que no hay ningún colombiano que haya vivido un solo día de paz en los últimos cincuenta años y si bien esta frase -repetida una y mil veces por el actual presidente Santos para darle legitimidad al proceso de negociación con las FARC- es cierta si se mira el conflicto como fenómeno global, deja de ser obvia cuando nos adentramos en el terreno de la vida cotidiana de municipios y veredas del país, incluyendo los más sistemáticamente golpeados por el conflicto.

En relación con lo anterior, otro elemento que puede percibirse en los distintos productos del GMH es que hay un intento manifiesto porque el recorrido por su extensión, sea en páginas (en el caso de los informes) o en minutos (para las producciones audiovisuales) vaya de lo general a lo particular, esté acompañado de explicaciones que demuestren la policausalidad del conflicto armado y no induzca a la polarización a favor o en contra de uno u otro de los actores del conflicto:

\footnotetext{
${ }^{78}$ Mauricio Builes mencionó, además de las citadas, la creación de una aplicación para teléfonos móviles, una historieta sobre los acuerdos de la verdad, una crónica radial y una multimedia basada en el ¡Basta ya!
} 


\begin{abstract}
A la luz de las consideraciones expuestas, el relato aquí plasmado intenta romper con las visiones reductoras de la violencia que condensan en coordenadas morales (los buenos y los villanos) la complejidad de lo que hemos vivido. La larga trayectoria del conflicto y las transformaciones de sus actores, junto a las transformaciones sociales e institucionales, clausuran toda pretensión de un relato monocausal que reduzca la continuidad de la violencia o su solución a la sola acción de los perpetradores o a un ejercicio de condena moral. La sociedad ha sido víctima pero también ha sido partícipe en la confrontación: la anuencia, el silencio, el respaldo y la indiferencia deben ser motivo de reflexión colectiva. No obstante, esta extensión de responsabilidades a la sociedad no supone la dilución en un "todos somos culpables" de las responsabilidades concretas y diferenciadas en el desencadenamiento y desarrollo del conflicto. La reconciliación o el reencuentro que todos anhelamos no se pueden fundar sobre la distorsión, el ocultamiento y el olvido, sino solo sobre el esclarecimiento. Se trata de un requerimiento político y ético que nos compete a todos ( $G M H, 2013$, p. 16).
\end{abstract}

Igualmente, la constante reivindicación de la resistencia y la dignidad de las víctimas, la recopilación de sus luchas y sus ejercicios de memoria, la alusión a los procesos de retorno a los lugares de los que fueron desplazados, así como a diferentes mecanismos gracias a los cuales han logrado hacer escuchar su voz y ser reconocidos por la sociedad, tiene un tono esperanzador (aunque no ingenuo) que, al presentarse casi siempre a manera de cierre, pretende que quién se aproxima a los trabajos de reconstrucción histórica del GMH conserve al final una sensación de que, pese a la barbarie y las constates amenazas que todavía existen, es posible actuar en la vía de una transformación social que le compete a todos los que hacen parte del país. Esta sensación fue confirmada por Mauricio Builes, quien indicó que la organización de cada producto del GMH parte de la pregunta de qué es lo que quiere generarse en el receptor, qué se espera que sienta quien ha leído un informe, visto un documental o recorrido una exposición. La respuesta ha sido que es importante que se conozca el horror, pero también, y sobre todo, la dignidad. No tendría sentido que quien termine su encuentro con un producto del GMH quede devastado y con la sensación de que todo está perdido. La apuesta es motivar la reflexión y la acción en pro de la superación de las condiciones que han permitido la existencia del conflicto armado, y para esto hay que contar con ciudadanos informados, críticos, sensibles, pero también esperanzados. Para Amparo Sánchez (2014, en comunicación personal) se trata, además de esto, de la instalación de otros héroes, no los convencionales, de las grandes gestas, sino personas comunes y corrientes que, ante situaciones atípicas y llenas de barbarie, no han quedado avasalladas sino que han decidido emprender un camino de recuperación para sí y para sus comunidades. Son ellos, los resistentes, los que han dignificado su condición de víctimas, los que ocupan el lugar de lo ejemplar en los informes del GMH. Si bien el propio grupo no declara este propósito de convertir a las víctimas en nuevos héroes, la lectura de Amparo Sánchez es interesante porque trae a colación la inversión, o imbricación más bien, de dos nociones que habían sido centrales en la tradición de las historias nacionales oficiales: el héroe y la víctima. Los informes del Grupo, en su constante reivindicación de la figura de la víctima y al apelar a la idea de la memoria como resistencia, instauran otra clase de heroicidad que no acompaña ya una historia nacional oficial sino unas memorias plurales de la nación colombiana que, aunque tienen la cualidad de lo oficial en los términos generales de aquello que emana del estado, no buscan ser una versión estática y única acerca del conflicto.

Desde la perspectiva de la construcción de sociedad, puede decirse que hay en el GMH una búsqueda de imparcialidad (a la manera de un árbitro en el campo deportivo), en tanto no se toma partido por ningún actor sino que se atribuyen responsabilidades con base en cifras, datos, testimonios. Si un árbitro está al servicio de las reglas del juego, ¿a favor de qué está el GMH? Podemos decir que está a favor del Estado (del pacto social, de la 
democracia), lo que es distinto de estar favor de uno u otro gobierno temporal. Asumir esta posición tiene sentido justamente porque se trata de un organismo estatal, desde donde es válido promover valores, apostarle a determinadas formas de lazo ciudadano, buscar cierta unidad de los habitantes como comunidad política en medio de la fragmentación enunciada y denunciada. No es lo mismo investigar y publicar desde la Universidad y en calidad de expertos que hacerlo desde el seno mismo del Estado. Los objetivos y las pretensiones del campo académico no son los mismos que los del campo político, así como no lo son sus responsabilidades. Gonzalo Sánchez es consciente de ello: "respecto a la experiencia del 87, nosotros estábamos hablando desde el mundo de la academia a petición del Estado, hoy en cambio, estamos haciéndolo desde el Estado mismo. El trabajo tiene la fuerza de la palabra del Estado" (Sánchez, entrevistado por Jaramillo, 2011b, p. 162). ¿Qué implica esta fuerza de la palabra del Estado? Desde nuestra perspectiva, implica el compromiso con un proyecto estabilizador del país el cual, en el contexto actual de Colombia, se encuentra necesariamente vinculado a la apuesta por la transición a un período de posconflicto. El Grupo de Memoria Histórica es uno de los mecanismos mediante los cuales el Estado colombiano, encarnado en los dos últimos gobiernos, ha procurado darle forma a un ambiente más propicio a la reconciliación, pero apelando ya no solamente a amnistías e indultos otorgados por decreto, sino promoviendo unas políticas de esclarecimiento y diálogo que involucran a la sociedad en pleno como actor importante a ser tenido en cuenta si se pretende que las negociaciones con grupos armados ilegales tengan efectos concretos tras una eventual culminación exitosa. Los informes del GMH, su difusión y discusión pública son instrumentos mediante los cuales puede lograrse una aproximación menos ingenua y más crítica de la población civil a la realidad del conflicto armado y, en esa medida, es comprensible la preocupación de un intelectual de la talla de Gonzalo Sánchez acerca de la responsabilidad que tiene el GMH como voz estatal que condensa las memorias de una guerra prolongada y degradada como la que se ha vivido en Colombia. La producción del GMH en medio de semejante contexto y dado su carácter de organismo estatal, no podía limitarse a una presentación pretendidamente objetiva de datos y conclusiones desprendidas de ellos, como se esperaría de un paper académico, sino que debía -y usamos aquí ese verbo de manera deliberada- hacer una apuesta ética en la que se jugasen las cartas para la construcción de una sociedad en la que los principales problemas identificados durante sus indagaciones como causantes y perpetuadores de la violencia puedan llegar a ser cuestionados, criticados e, idealmente, transformados. Volvemos a traer aquí la idea de imparcialidad, en lugar de la de objetividad, como algo deseable para un Grupo como el de Memoria Histórica. Mientras la idea de objetividad tiene las resonancias (tan criticadas actualmente) de la ciencia positivista sobre la pretensión de indagar un fenómeno sin alterarlo, pensamos en la imparcialidad como una actitud ética que implica, en los análisis de fenómenos sociales en los que hay en juego varios actores, no tomar partido por ninguno de ellos, sino establecer un principio de orden superior, basado en un consenso (Ramírez, 1992) en virtud del cual se analizan sus acciones. En el caso del GMH consideramos que tal principio de orden superior está anclado al proceso ético-político que le dio origen, relacionado directamente con la búsqueda del establecimiento de unas condiciones políticas y sociales que hagan viable la instalación de un período de posconflicto que está siendo propiciado mediante el diálogo y la desmovilización de grupos armados ilegales, pero que requiere de un posicionamiento distinto de la sociedad respecto de su propia realidad.

Para tal fin, uno de los aportes del ¡Basta ya! para un país tan inmediatista como Colombia es la recopilación de políticas, iniciativas y estrategias para el tratamiento del conflicto armado que se han dado a lo largo de más de 50 años según los diferentes gobiernos, haciendo posible identificar los ires y venires de lo que ha sido un proceso de décadas en el que se han ensayado tanto posiciones radicales de confrontación armada como otras más 
moderadas y abiertas al diálogo. Esto, sumado al intento por presentar un panorama comprensivo de la violencia y del conflicto que anuda razones de distintos órdenes, mostrar relaciones y confluencias de intereses, posicionar a las víctimas como sujetos políticos y de derecho (y no simplemente como seres por los que debe sentirse compasión, aunque esta no se excluye) y cuestionar una y otra vez a una sociedad que por décadas ha sido testigo a veces pasivo, a veces cómplice, a veces indiferente- de la violencia y el conflicto que el Grupo caracteriza como guerra, es la contribución que, a manera de apuesta, hace el GMH a un país desangrado y fragmentado que se encuentra, una vez más, ante la posibilidad de firmar un acuerdo de paz que será apenas el comienzo para comenzar a construirla y a buscarla. 


\section{CONCLUSIONES}

Emprender una investigación supone, tal vez como única certeza, que no se sabe al comenzar qué rumbos tomará la pregunta de la que se ha partido y a través de qué recovecos y variaciones irán apareciendo luces que permitan aproximarse a su respuesta. Esta tesis comenzó como una inquietud acerca del discurso oficial sobre el conflicto armado colombiano en el pasado reciente, partiendo del supuesto de que los pronunciamientos, acciones y producciones que provienen del Estado tienen un potencial superior al de otros discursos para instalarse en la esfera pública e incidir en el saber y posiciones de los ciudadanos sobre una realidad particular. Siendo el conflicto armado un asunto central del Estado colombiano, un problema que casi podría decirse que ha definido a ese país como Nación en las siete últimas décadas (convirtiéndolo incluso en tema de estudio para investigadores internacionales), se consideró pertinente hacer un rastreo de las posturas asumidas por diferentes gobiernos a lo largo de su transcurso en términos de memoria y de olvido, especialmente en el pasado reciente. Al encontrarnos con que existía ya una detallada investigación acerca de las Comisiones de Estudio sobre la violencia en Colombia desde 1958 hasta el año 2010 (Jaramillo, 2011), decidimos centrar nuestra atención en la más reciente iniciativa estatal relacionada con este tema: el Grupo de Memoria Histórica -GMH-. Una de sus principales particularidades era justamente que se trataba del primer emprendimiento de memoria promovido directamente desde el Estado colombiano y que, a diferencia de experiencias anteriores, no pretendía ser un diagnóstico elaborado por expertos acerca de las situaciones asociadas al conflicto y la violencia, sino que se buscaba hacer una reconstrucción de las causas que dieron origen a los grupos armados ilegales y a los estragos que su accionar habían dejado a lo largo del territorio en los más de cincuenta años de confrontación.

¿Cómo se haría esa reconstrucción? ¿Quiénes serían los encargados de contar esa historia desgarradora de la Nación? ¿Desde qué presupuestos éticos construirían su relato? ¿Qué período abarcarían y por qué? ¿Cuáles voces ocuparían el lugar central? ¿Qué tipo de interpretaciones y sentidos se promoverían? ¿Bajo qué formatos? ¿Usando qué tipo de estrategias discursivas? ¿Con qué intencionalidad respecto al Estado mismo, a los actores armados, a los afectados, a la sociedad civil? Estas fueron las cuestiones que, poco a poco, se convirtieron en el centro de la indagación y alrededor de las cuáles se estructuró la tesis. Se asumió al GMH, en tanto organismo estatal, como portador principal del discurso oficial acerca del conflicto armado en los años recientes y se tomaron como ejes de análisis tanto el contexto y proceso de su conformación como el contenido de su amplia producción escrita al respecto.

El Grupo de Memoria Histórica, una derivación de la Ley de Justicia y Paz del año 2005, se convirtió en el centro de nuestra indagación. No sólo resultaba sorprendente su creación durante un gobierno que se había empeñado como pocos en la búsqueda de la terminación del conflicto armado por la vía de la derrota militar de los actores ilegales, sino que su propia composición resultaba llamativa, pues no lo conformaban precisamente figuras afines a esa postura de gobierno. Una de las conclusiones importantes que surgió de esta indagación es que no puede pensarse el Estado como un ente monolítico en el que todas sus partes son comandadas por un solo y mismo centro, sino que existen en su interior diferentes tipos de instituciones y agrupaciones con intereses y presupuestos propios, de cuya relación surgen tensiones y disputas que han de ser resueltas no necesariamente en la vía de lo que una jefatura temporal de gobierno indique. Aun reconociendo esto, una de las primeras paradojas asociadas al GMH es que se trata de un organismo que no existía antes de la Ley de Justicia Paz, lo que quiere decir que la tensión entre la posición que asumieron 
sus investigadores frente al asunto de un conflicto armado que pretendía ser desconocido como tal por el presidente de la época, se instaló como efecto de una Ley sancionada por él mismo. Paradoja de una tensión creada cuyos efectos parecieran no haber sido calculados por el gobierno del momento pero cuya inestabilidad sí fue leída por un GMH que se dedicó a conseguir financiación internacional y a producir en poco tiempo un abundante y riguroso material sobre el conflicto armado. En lo que a nuestro juicio fue una jugada estratégica para no entrar en abierta discordia con la postura "negacionista" de Uribe Vélez, ninguno de los informes editados durante su mandato se refiere en los títulos al conflicto armado. La categoría empleada en su lugar es la de guerra que, además de ser usada recurrentemente en sus informes como intercambiable con "conflicto armado", deja traslucir también una posición del GMH y, en particular, de su director, Gonzalo Sánchez: la confrontación armada colombiana ha tenido y sigue teniendo un cariz fundamentalmente político y, desde su perspectiva, reconocerla como guerra es lo más pertinente para no perder de vista este hecho. Otra razón complementaria, pero igualmente importante para captar la forma en que el GMH ha asumido su función de construir y transmitir las memorias del conflicto es que la palabra guerra tiene unas resonancias más fuertes y menos académicas que la de conflicto armado y, en esa medida, es más susceptible de generar un impacto en los potenciales lectores de sus diferentes informes. Un análisis de la estructura formal de los mismos y el lenguaje que en ellos es empleado nos llevó a la conclusión de que el manejo que hacen del discurso cumple una función esencial en sus propósitos de transmitir un relato que cumpla, a nuestro entender, con al menos cuatro condiciones básicas: 1) sensibilizar a las personas que no han vivido directamente los embates del conflicto; 2) generar reflexión en torno a las causas estructurales de la confrontación para entenderla en un marco amplio, en el que la atribución de responsabilidades es compleja y no pueden simplemente identificarse "malos" y "buenos"; 3) hacer una crítica del papel que el Estado y un gran número de funcionarios e instituciones han asumido a lo largo de estas décadas de violencia; 4) interpelar a la sociedad civil que ha sido en ocasiones cómplice de las acciones armadas ilegales (por acción, por omisión o por justificar las agresiones hacia algunas comunidades) y, en otras, ha actuado con indiferencia ante las miles de víctimas que han sufrido las acciones de todos los actores del conflicto (legales e ilegales).

Volviendo sobre las paradojas en las que se asentó el trabajo del $\mathrm{GMH}$, hay otra que fue uno de los principales focos de inquietud en el desarrollo de este trabajo: la segunda de las leyes que reguló su hacer y amplió sus funciones, al convertirlo en Centro Nacional de Memoria Histórica, incluye un parágrafo que prohíbe explícitamente la elaboración de una verdad oficial acerca del conflicto armado por parte de organismos estatales. Numerosos teóricos de la memoria que han advertido de los peligros de que sea el Estado el que emprenda acciones de memoria han fundado sus temores y sus críticas precisamente en el riesgo hegemonizante que tienen las producciones estatales y, en particular, advierten sobre los peligros de que se termine elaborando una verdad oficial sobre hechos violentos que desconozca las voces de los vencidos, de los oprimidos, de las víctimas de las fuerzas estatales. Si el GMH iba a ser el portavoz oficial de la memoria, ¿cómo garantizar que lo que iban a contar no terminara por convertirse en una verdad igualmente oficial? Hizo falta para encarar este asunto distinguir entre varios sentidos de lo oficial y admitir que, si bien los informes del GMH son oficiales en el sentido amplio que reviste de oficialidad cualquier acción o producto que depende o procede del Estado, no lo es en términos de constituir una versión cerrada, incuestionable y simplista de una serie de acontecimientos en los que el Estado mismo está implicado, y no siempre como veedor del orden y protector de los derechos ciudadanos. La sola vastedad de la producción del GMH, que abarca decenas de investigaciones sobre casos emblemáticos del conflicto ocurridos en distintos puntos del territorio nacional, así como textos temáticos que analizan las diversas problemáticas que han atravesado las confrontaciones, además de un archivo de las iniciativas independientes 
de memoria que han tenido lugar en muchas comunidades (la mayoría de las veces sin acompañamiento estatal), dan cuenta de que no ha sido el interés del Grupo mostrar una visión simplificada del conflicto armado que saque en limpio al Estado colombiano, sino más bien mostrar las dimensiones de lo que ha vendido sucediendo, sus recurrencias, complejidad y, sobre todo, la capacidad que han tenido víctimas, testigos y sobrevivientes para sobreponerse a los atropellos y pérdidas sufridos y para luchar por su dignidad en un país que durante largos períodos les ha dado la espalda.

Respecto a las víctimas del conflicto armado (entre las que el GMH incluye a las personas que se han visto afectadas de manera directa o indirecta por la acción de los actores armados legales e ilegales, así como por las consecuencias de las confrontaciones), son ellas justamente quienes llevan la voz cantante en los informes, pues el GMH, como apuesta ética, decidió que era fundamental dentro de su trabajo hacer visibles los testimonios de las personas que se han llevado la peor parte de la guerra pero que no habían sido reconocidas por la sociedad en su dimensión humana y subjetiva, aunque se hubieran hecho algunos avances en su reconocimiento legal, que implicaba reparaciones por vía administrativa (indemnizaciones económicas y atención básica de sus derechos fundamentales). Los informes del GMH cuentan con nombre propio las historias de cientos de personas que murieron, que fueron vejadas, despojadas de tierras y pertenencias, secuestradas, torturadas, amenazadas. Las razones del Grupo para dar este privilegio a la voz de las víctimas son éticas y también políticas: consideran que el Estado y la ciudadanía están en mora de asumir a las víctimas como parte integrante de la sociedad y, además, se asume casi como imperativo la necesidad de restituir la dignidad a unas personas a las que les fue arrebatada por los actores armados. Quizá, como plantea Rabotnikof (2007), el GMH concuerda con que "aunque no se pueda castigar o no se pueda compensar o reparar a las víctimas, el hecho de señalar los crímenes y reconocer públicamente el sufrimiento es ya una afirmación de democracia y de refundación social". Vemos aparecer ante nuestros ojos las mismas inquietudes, los mismos rituales -si se admite el símil- que rodearon la reivindicación tardía de las víctimas del Holocausto nazi, ese modelo por excelencia de las luchas por la memoria (Huyssen, 2001). En el caso colombiano, lo tardío es relativo: el conflicto no ha cesado y, en esa medida, la experiencia del GMH es sui generis respecto a otras que se han dado en el mundo. Sin embargo, tampoco se trata de un evento "breve", circunscrito únicamente a los últimos cinco o diez años. No. Son décadas las que suma la confrontación armada y, por tanto, también puede identificarse una tardanza en la búsqueda de dignificación de muchas de las víctimas y sobrevivientes, pues no son pocas las que han fallecido esperando reparaciones simbólicas o económicas, aguardando porque al menos su buen nombre, según diversos testimonios recogidos en los informes del GMH, les fuera restituido. He aquí una tercera paradoja que atraviesa de lado a lado las producciones del Grupo: hacen memoria de un pasado que, más que reciente, sigue siendo un pasado presente o, como ellos mismos lo dijeran al titular uno de sus primeros trabajos, memorias en tiempo de guerra.

El carácter estatal del GMH y su compromiso abierto y sin ambages con las voces y la dignidad de las víctimas, imprime a sus informes y todas sus elaboraciones un tono que, para algunos, puede parecer militante, pero que ellos justifican a partir de la invocación de una responsabilidad política que no le compete solo a los gobiernos de turno sino al Estado y la sociedad colombiana en su conjunto. Lo que ha sucedido no es ajeno a los designios de sucesivos gobiernos y grupos poderosos de ciudadanos o empresarios, pero tampoco lo es a una ciudadanía que ha aceptado y perpetuado en el poder a quienes han orquestado un ambiente de fragmentación y desconfianza que se ha apuntalado en razones ideológicas, económicas, políticas y religiosas. Los informes del GMH denuncian, explican, interrogan e instan a que cada persona que se encuentra con sus informes se pregunte de qué manera 
su actitud ha influido, por poco que parezca, en el devenir del conflicto armado y qué ha hecho o podría hacer para incidir de otra manera en el curso de los acontecimientos. Sin que se diga explícitamente, hay una búsqueda por hacer que el lector asuma una posición activa y se reconozca como sujeto político que tiene algún papel que desempeñar en la transformación de la situación casi cíclica del país.

Esta pretensión hace encajar el trabajo del GMH en otro de los referentes fundamentales del campo actual del estudio y las luchas por la memoria: hacen una reconstrucción del pasado desde el contexto del presente, pero siempre con miras a la construcción de un futuro en el que la guerra no sea ya la protagonista absoluta de la historia de Colombia. Por eso, pese a ser un grupo conformado principalmente por reconocidos académicos e intelectuales, no instalan sus construcciones en el terreno aséptico de la evaluación y el diagnóstico investigativo. No se limitan a describir las cosas como son y a explicar las posibles causas y relaciones intercausales que han llevado a este estado de cosas, sino que asumen una postura ética y política desde la cual le apuntan también a un deber ser que consideran mejor y más conveniente para el destino de la Nación: aparecen allí la importancia de la salida negociada del conflicto armado, el respeto de los derechos humanos, la revisión de las causas estructurales de la violencia (disputas por la tierra, desigualdad, precariedad democrática, intolerancia hacia la diferencia, corrupción e impunidad, entre otras) y la necesidad de adelantar acciones que permitan superarlas; la generación de sensibilidad y consciencia amplia de la ciudadanía de las implicaciones que tiene vivir en un país en guerra, aun si no todos sus habitantes padecen en carne propia las consecuencias de la misma.

En suma, el trabajo del $\mathrm{GMH}$, tanto en sus producciones escritas como audiovisuales, parece estar organizado de tal modo que los lectores y espectadores transiten un camino que va de lo racional a lo emocional y que culmina con la instalación de un sentimiento de esperanza, como se detalló en el último capítulo. Si los informes del GMH estuvieran inscritos dentro de la lógica académica esto podría ser fuertemente criticado, pues su predilección por hacer aparecer las voces de los más afectados por el conflicto, sus interpelaciones morales y éticas al lector, sus recomendaciones a favor de un estado de cosas inexistente pero deseable, podrían perfectamente catalogarse como interferencias o sesgos para entender el fenómeno del conflicto. Sin embargo, si se tiene en cuenta que no se trata de una comisión de estudio cuyo objetivo sea la producción de un dictamen experto, y se mantiene en mente el hecho de que una de las funciones primordiales aunque sea idealmente- de las acciones estatales es buscar una suerte de armonía que permita la convivencia pacífica de quienes lo integran, es menester reconocer que las elaboraciones del $\mathrm{GMH}$, como organismo estatal, pretenden contribuir a dicho fin.

En un país que tradicionalmente no le había dado un lugar importante a la historia de su confrontación armada, en el que ni siquiera existe una asignatura exclusiva para la historia en los currículos escolares, y en el que el contexto permanente de miedo y zozobra por la continuidad de la guerra ha hecho que sea el silencio el que se imponga, especialmente entre las víctimas y testigos de la misma, la creación de un organismo como el Grupo de Memoria Histórica es de una importancia capital: allí donde nadie contaba lo que había pasado, empiezan a emerger una variedad de relatos en diferentes regiones que pueden hacerse oír por la intermediación de una entidad oficial y, merced al tipo de construcción que ha hecho el $\mathrm{GMH}$, las personas afectadas pueden comenzar a relacionar lo que les sucedió y les parecía tal vez único, con una historia más amplia que cobija a toda la nación. Justamente uno de los esfuerzos más patentes en la producción del GMH es establecer esa conexión no siempre obvia ni sencilla entre lo local y lo nacional, señalando regularidades, 
recurrencias y estrategias que conectaban las acciones de los grupos armados aun donde daban la impresión de ser hechos aislados.

Por ahora, no es claro cuánto tiempo más durará el Centro (antes Grupo) de Memoria Histórica ni mucho menos el conflicto armado. Lo que queda claro es que lo que han hecho hasta el momento es una contribución importante para el esclarecimiento histórico del mismo y para otorgarle un lugar diferente y quizá necesario a las miles de víctimas que ha dejado. Del mismo modo, se han venido trazando unas vías de circulación de su producción que han apelado al uso de los medios masivos de comunicación y las redes sociales y que, poco a poco, han ido permeando el espacio público e instalando debates que hasta hace unos pocos años no se presentaban en el grueso de la sociedad. El país está hablando ahora de víctimas, de memoria, de responsabilidades, de un posible posconflicto y, aunque sería ingenuo suponer que la confrontación cesará de un día para otro con la firma de tratados con algunos de los grupos armados, también lo sería no reconocer que hay circunstancias que se están transformando y que parecen favorecer -aunque, por supuesto, no garantizar- un futuro menos violento para Colombia. Alguna de las personas entrevistadas para el desarrollo de este trabajo dijo que creía que el país no sería el mismo si no se hubiera creado el Grupo de Memoria Histórica. Está por verse cuánta razón le asiste. 


\section{BIBLIOGRAFÍA}

Acevedo, Tatiana. (2011, 9 de julio). A la espera de una generación menos angustiada. El Espectador. [En línea] Disponible en:

http://www.elespectador.com/impreso/politica/articulo-285665-espera-de-una-generacionmenos-angustiada. Recuperado el 27 de noviembre de 2011.

Aguilera, M. (2001). Amnistías e indultos, siglos XIX y XX”. En: Revista Credencial Historia (137) pp. 8-13.

Anderson, Benedict. (1983). Imagined Communities: Reflections on the Origin and Spread of Nationalism. London: Verso.

Angenot, M. (2010). El discurso social. Los límites de lo pensable y lo decible. Buenos Aires: Siglo XXI.

Arendt, H. (2005) [1969]. Sobre la violencia. Madrid: Alianza.

- (2003) [1964] Personal responsibility under totalitarian dictatorship. En: Responsibility and Judgment, Random House, New York [Responsabilidade pessoal sob a ditadura. En: Arendt, H. (2003) Responsabilidade e Julgamento, Companhia das Letras, Sao Paulo].

Ayala Diago, C. (1999). Frente Nacional. Acuerdo bipartidista y alternación del poder. Revista Credencial Historia (119). En línea [Disponible en]: http://bit.ly/14XIQlu

Bardin, Laurence. (1986). Análisis de contenido. Madrid: Akal.

Bejarano, JA. (1995). Una agenda para la paz. Bogotá: Tercer Mundo.

Blair, E. 2009. Aproximación teórica al concepto de violencia: avatares de una definición. Política y cultura (32), 9-33.

- (2008). Los testimonios o las narrativas de la(s) memoria(s). En: Estudios políticos (32) pp. 85-115.

Blair, E. et al. (2008). De memorias y de guerras. La Sierra, Villa Liliam y el 8 de marzo en Medellín. Medellín: Alcaldía de Medellín.

Borja G., Jaime Humberto. (1999). Ciencias sociales 7. Bogotá: Santillana.

Bourdieu, P. (1995). La práctica de la antropología reflexiva. En: Bourdieu, P. y Wacquant, L. Respuestas, para una antropología reflexiva. México: Grijalbo, pp. 159-196.

. (1989-1992). Cómo se forma la opinión pública (inédito, traducido por Teresa Garufi). [En línea] Disponible en: http://www.eldiplo.org/notas-web/como-se-forma-la-opinion-publica Recuperado el 20 de febrero de 2012.

- (1982). La representación política. Elementos para una teoría del campo político. En: Actes de la Recherche en Sciences Sociales (36-37) pp. 3-24. Traducción de David Velasco. 
Braudel. F. (1968). La historia y las ciencias sociales. Madrid: Alianza.

Bushnell, David. (1994). Colombia: una nación a pesar de sí misma. De los tiempos precolombinos a nuestros días. Bogotá: Planeta.

Camacho Guizado, Álvaro. (1991). El ayer y el hoy en la violencia en Colombia: continuidades y discontinuidades. Análisis político (12).

Castoriadis, Cornelius (1996) "La democracia como procedimiento y como régimen" http://www.inisoc.org/Castor.htm

CNNR. (2007). Disidentes, rearmados y emergentes: ¿bandas criminales o tercera generación paramilitar? Recuperado de: http://bit.ly/1aJdtAU

Comisión de Estudios sobre la Violencia. (1987). Colombia: Violencia y Democracia. Bogotá: Centro Editorial Universidad Nacional.

Conadep. (1984). Nunca más. Buenos Aires: EUDEBA.

Coser, L. (1956). The functions of social conflict. New York: The Free Press.

Crenzel, E. (2006). La historia política del Nunca Más. México: Siglo XXI.

Cristancho, JG. (2011). Gonzalo Sánchez: trayectoria de una experiencia de memoria de la violencia en Colombia. Revista colombiana de educación (61), pp. 73-88.

Da Silva Catela, L. de S. (2011). Pasados en conflicto. De memorias dominantes, subterráneas y denegadas. Inédito.

De Certeau, M. (1993). La escritura de la historia. México: Universidad Iberoamericana.

Didi-Huberman, G. (2004). Imágenes pese a todo. Memoria visual del Holocausto. Barcelona: Paidós.

Duplat, T. Paz en la Guerra Experiencias comunitarias por la paz y construcción de democracia en Colombia: El proceso de reconciliación y convivencia del Alto Ariari. (Tesis doctoral). Universidad de Granada, Granada, España.

Equipo Nizkor. (2007). Decreto 3398 de 1965 y Ley 48 de 1968 por los que se legalizan las fuerzas paramilitares. Recuperado de: http://www.derechos.org/nizkor/colombia/doc/paras1.html

FARC. (1998). Carta abierta al Dr. Andrés Pastrana, Presidente de la República de Colombia. Hechos de paz (V-VI), 233.

Feld, C. (2002). Del estrado a la pantalla: las imágenes del juicio a los ex comandantes en Argentina. España: Siglo XXI.

Fisas, Vicent (1998). Cultura de Paz y Gestión de conflictos. Barcelona: Icaria-UNESCO.

Galindo Caballero, M y Valencia Cuéllar, J. En carne propia: ocho violentólogos cuentan sus experiencias como víctimas de la violencia. Bogotá: Intermedio. 
García-Peña, D. (2005). La relación del Estado colombiano con el fenómeno paramilitar: por el esclarecimiento histórico. Análisis político (53), 58-76. Recuperado de:

http://www.scielo.org.co/pdf/anpol/v18n53/v18n53a04.pdf

Giesen, B. (2004). Triumph and Trauma. Boulder: Paradigm Publishers.

Gímenez, G. (2005). Teoría y análisis de la cultura. Vol. I. México: CONACULTA- ICOCULT.

Grupo de Memoria Histórica. (2008). Trujillo: una tragedia que no cesa. Bogotá: Planeta.

- (2009a). Recordar y narrar el conflicto. Herramientas para reconstruir memoria histórica. Bogotá: Fotoletras.

. (2009b). Memorias en tiempo de guerra. Repertorio de iniciativas. Bogotá: Puntoaparte.

. (2010a). Silenciar la democracia. Las masacres de Remedios y Segovia 1982-1997. Bogotá: Taurus. . (2010b). Bojayá. La guerra sin límites. Bogotá: Taurus.

Bogotá: Taurus.

(2011a). La huella invisible de la guerra. Desplazamiento forzado en la Comuna 13. . (2011b). San Carlos. Memorias del éxodo en la guerra. Bogotá: Taurus.

. (2011c). La reconstrucción de la memoria histórica desde la perspectiva de género. Conceptos y herramientas. Bogotá: Pro-Offset.

. (2012). Justicia y paz: ¿verdad judicial o verdad histórica? Bogotá: Taurus.

Nacional.

. (2013). ¡Basta ya! Colombia: memorias de guerra y dignidad. Bogotá: Imprenta

Guzmán Campos, G; Fals Borda, O; Umaña Luna, E. (2010) [1962]. La violencia en Colombia. Tomos I y II. Bogotá: Punto de lectura.

Halbwachs, M. (1968) (2004). La memoria colectiva. Zaragoza: Prensas Universitarias de Zaragoza. . (2004). Los marcos sociales de la memoria. Barcelona: Anthropos.

Hammersley, M. y Atkinson, P. (1994). Etnografía. Métodos de investigación. Barcelona, Paidós, cap. 6, pp. 143-159 ("Documentos").

Herrera, M y Cristancho, JG. (2013). En las canteras de Clío y Mnemosine: apuntes historiográficos sobre el Grupo de Memoria Histórica. Historia crítica (50), 183-210.

Hilb, Claudia (2000). Violencia y política en la obra de Hannah Arendt. En: Postdata, 6. pp. 75105 
Holguín, J. (1908). Desde cerca: asuntos colombianos. París: Librairie Générale et Internationale

Huyssen, A. (2001). En busca del futuro perdido. Cultura y memoria en tiempos de globalización. México: Fondo de Cultura Económica.

Gutiérrez, F; Wills, M.E; Sánchez, G. (Ed). (2006). Nuestra guerra sin nombre: transformaciones del conflicto en Colombia. Bogotá: Norma.

IGAC. (2012). Atlas de la distribución de la propiedad rural en Colombia. Bogotá: Imprenta Nacional de Colombia.

Jaramillo Marín, J. (2011). Las comisiones de estudio sobre la violencia en Colombia: tramas narrativas y ofertas de sentido temporal para comprender la violencia. Facultad Latinoamericana de Ciencias Sociales -FLACSO-, Sede Académica de México.

, J. (2011a). La Comisión Investigadora de 1958 y la Violencia en Colombia. Universitas Humanística (72), 37-62.

. (2011b). Las comisiones de estudio sobre la violencia. La voz crítica de uno de sus protagonistas. Entrevista con el historiador Gonzalo Sánchez. Análisis Político (73), pp. 159168.

. (2009). Tres procesos "emblemáticos" de recuperación de pasados violentos: Argentina, Guatemala y Colombia. En: Revista de Antropología y Sociología de la Universidad de Caldas, 11: 29-59.

Jaspers, Karl. (1998). El problema de la culpa. Sobre la responsabilidad política de Alemania. Barcelona: Paidós.

Jelin, E. (2002). Los trabajos de la memoria. España: Siglo XXI.

. (2003). Los derechos humanos y la memoria de la violencia política y la represión: la construcción de un campo nuevo en las ciencias sociales. Cuadernos del IDES (2), 3-28.

. (2007). La conflictiva y nunca acabada mirada sobre el pasado. En: Franco, M. y Levin, F. (eds). Historia reciente. Perspectivas y desafíos para un campo en construcción. Buenos Aires: Paidós, 2007.

Koselleck, R. (1993). Futuro pasado. Para una semántica de los tiempos históricos (2a ed). Barcelona: Paidós.

Lair, E. (2000). Colombia: una guerra contra los civiles. Colombia internacional (49-50), 135147.

Levi, P. (2002) [1958]. Si esto es un hombre. Barcelona: Muchnik.

Llano Isaza, R. (2007). Curiosidades de nuestra primera república. En: Credencial Historia (211). Recuperado de:

http://www.banrepcultural.org/blaavirtual/revistas/credencial/julio2007/primerarepublica.html

López, C. y Sevillano, O. (2008). Balance político de la parapolítica. Arcanos (14) 62-87. Recuperado de: http://www.arcoiris.com.co/wp-content/uploads/2011/arcanos/revista_ARCANOS 14.pdf 
Luengo Cruz, M. (2008). El producto cultural: claves epistemológicas de su estudio. Zer 13 (24), 317-335.

Machado, A. (2004). Tenencia de tierras, problema agrario y conflicto. En: Desplazamiento Forzado. Dinámicas de Guerra Exclusión y Desarraigo. ACNUR. Universidad Nacional de Colombia. Recuperado de:

http://www.virtual.unal.edu.co/cursos/humanas/2004945/docs_curso/descargas/2da\%20sesion/Basica/Absalon\%2 oMachado.pdf

Melo, JO. (1997). Gaitán: el impacto y el síndrome del 9 de abril. En: Credencial Historia (96) Recuperado de:

http://www.banrepcultural.org/blaavirtual/revistas/credencial/diciembre1997/9602.htm

. (1996). La república liberal. En: Melo, JO (Coord.). Colombia hoy. Recuperado de: http://www.banrepcultural.org/blaavirtual/historia/colhoy/colo5.htm

Mejía Pavony, G. (2009, julio 18). ¿La patria boba? Semana. Recuperado de: http://www.semana.com/especiales/articulo/la-patria-boba/105278-3

Misión de Observación Electoral -MOE- (2008). Monografía político electoral, departamento de Antioquia, 1997-2007. Recuperado de:

http://moe.org.co/home/doc/moe_mre/CD/PDF/antioquia.pdf

Nora, P. (1984) [2008]. Pierre Nora en Les lieux de mémoire. Buenos Aires: Trilce.

Paramilitares se habrían unido. El Tiempo (1997, 20 de abril), El Tiempo. Recuperado de: http://www.eltiempo.com/archivo/documento/MAM-513963

Pécaut, D. (1987). Orden y violencia: Colombia 1930-1954. Bogotá: Siglo XXI. . (2001). Guerra contra la sociedad. Santafé de Bogotá: Espasa.

. (2004). Memoria imposible, historia imposible, olvido imposible. En: Memorias en conflicto, Aspectos de la violencia política contemporánea. Lima: IEP-IFEA. pp. 87-104.

- (2009). La "guerra prolongada" de las FARC. Istor: Revista de historia internacional, 37. pp. 36-47.

Pizarro Leongómez, E. (1987). La profesionalización militar en Colombia (1907-1944). Análisis político, 1. Recuperado de: http://www.iepri.org/portales/anpol/o1.pdf

- (1987). La profesionalización militar en Colombia II: el período de La Violencia. Análisis político, 2. Recuperado de: http://www.iepri.org/portales/anpol/oz.pdf

- (1989). Los orígenes del movimiento armado comunista en Colombia (19491966). Análisis político, 7. Recuperado de:

http://biblioteca.clacso.edu.ar/ar/libros/colombia/assets/own/analisis07.pdf

- (1991). Elementos para una sociología de la guerrilla en Colombia. Análisis político, 12. Recuperado de: http://biblioteca.clacso.edu.ar/ar/libros/colombia/assets/own/analisis12.pdf 
- (2002). Colombia: ¿guerra civil, guerra contra la sociedad, guerra antiterrorista o guerra ambigua? Análisis político (46), 164-180.

. (2004, 9 de mayo). Marquetalia: el mito fundacional de las FARC. UN Periódico. Recuperado de: http://historico.unperiodico.unal.edu.co/Ediciones/57/03.htm

Pollak, M. (2006). Memoria, olvido, silencio. La Plata: Al Margen.

. (1986) [2010]. A gestão do indizível. En: WebMosaica. Revista do instituto cultural judaico Marc Chagall 2(1), 9-49.

Pons, MC. (1996). Memorias de olvido: Del Paso, García Márquez, Saer y la novela histórica de fines del siglo XX. México: Siglo XXI.

Posada Carbó, E. (2001). ¿Guerra civil? El lenguaje del conflicto en Colombia. Bogotá: Alfaomega.

Programa de las Naciones Unidas para el Desarrollo -PNUD-. (2004). La democracia en América Latina. Hacia una democracia de ciudadanas y ciudadanos. Buenos Aires: Alfaguara.

Ramírez, CA. (1992). Introducción a la filosofía de las ciencias. Medellín: Inédito.

Renan, E. (1882) ¿Qué es una nación? [Recuperado de:] http://www.paginasprodigy.com/savarino/renan.pdf

República de Colombia. Ley 1448 de 2011.

República de Colombia. Ministerio de Justicia y del Derecho. Decreto 4803 del 20 de diciembre de 2011.

Ley 975 de 2005.

Retamozo B, Martín. (2009). Lo político y la política: los sujetos políticos, conformación y disputa por el orden social. En: Revista Mexicana de Ciencias Políticas y Sociales, LI (206). pp. 69-91.

Reyes Mate, M. (2011, julio 21). Reyes Mate: "Existe un deber de memoria, porque al conocimiento se le escapa mucha realidad". Revista de letras. Recuperado de: http://revistadeletras.net/reyes-mate-existe-un-deber-de-memoria-porque-al-conocimientose-le-escapa-mucha-realidad/

Reyes Posada, A. y Correa, H. (1992). Pacificar la paz: lo que no se ha negociado en los acuerdos de paz. Bogotá: Instituto de estudios políticos y relaciones internacionales, CINEP, Comisión Andina de Juristas y Centro de Cooperación al Indígena.

Safford, F. y Palacios, M. (2002). Colombia: país fragmentado, sociedad dividida: su historia. Bogotá: Norma.

Salvi, V. (2009). Memoria completa: una retórica del sufrimiento. Ponencia presentada en la VIII Reunión de Antropología del Mercosur. Buenos Aires, 2009. Recuperado de: http://www.ram2009.unsam.edu.ar/ 
. (2011). Violencia, olvido y victimización colectiva. El discurso de las agrupaciones de "Memoria Completa". Ponencia presentada en el IV Seminario Internacional Políticas de la Memoria. Centro Cultural Haroldo Conti. Buenos Aires, 2011. Recuperado de: http://www.derhuman.jus.gov.ar/conti/2011/10/mesa_24/salvi_mesa_34.pdf

Sánchez, G. (1991). Guerra y política en la sociedad colombiana. Bogotá: Áncora.

Sánchez G. (1993). Los intelectuales y la violencia. En: Análisis político (19) 40-48.

. (2000). Guerra prolongada, negociaciones inciertas en Colombia. En: Bulletin de L'Institute Français d'Études Andines (29-3). pp. 269-305. [En línea] Disponible en: http://redalyc.uaemex.mx/src/inicio/ArtPdfRed.jsp?iCve=12629302 Recuperado el 21 de mayo de 2012.

. (2001). El compromiso social y político de los intelectuales. En: Journal of the Iberian and Latin American Studies (7:2) 133-150.

. (2006). Guerras, memoria e historia (2 ed.). Medellín: La Carreta.

. (2011). Las comisiones de estudio sobre la violencia. La voz crítica de uno de sus protagonistas. Entrevista con el historiador Gonzalo Sánchez (a cargo de Jefferson Jaramillo). Análisis político (73), 159-168.

Sánchez, G; Díaz, AM; y Formisano, M. (2003). Conflicto, violencia y actividad criminal en Colombia: un análisis espacial. Documento CEDE. Bogotá: Universidad de los Andes.

Sánchez, G y Reátegui, F. (Abril 2012). El deber de la memoria. En: Encuentro internacional de escritores. Conversaciones que le cambiarán la vida. Conversatorio realizado en la Feria del libro de Bogotá.

Schmitt, Carl. (1998) [1932]. El concepto de lo político. Madrid: Alianza.

Schuter, S. Colombia, ¿país sin memoria? Pasado y presente de una guerra sin nombre. En: Revista de Estudios Colombianos (36) pp. 30-49.

Semprún, J. (1995). La escritura o la vida. Buenos Aires: Tusquets.

Soprano (2007). Del Estado en singular al Estado en plural. En: Cuestiones de sociología (4) $19-48$.

Tirado Mejía, A. (1995). Aspectos sociales de las guerras civiles en Colombia. Medellín: Seduca.

. (1996). Colombia: siglo y medio de bipartidismo. En: Melo, J O. (Coord.). Colombia hoy. Bogotá: Presidencia de la República.

Todorov, T. (2000). Los abusos de la memoria. Buenos Aires: Paidós Asterisco.

Torre Duque, O (2004). El mausoleo iluminado. Historia del ensayo en Colombia. Gonzalo Sánchez Gómez. [En línea] Disponible en: 
http://www.banrepcultural.org/blaavirtual/historia/ensayo/gonzalo.htm [En línea] Disponible en: http://www.banrepcultural.org/blaavirtual/historia/ensayo/gonzalo.htm (Consulta realizada el 4 de agosto de 2011)

Traverso, E. (Junio de 2013). La memoria y los usos públicos del pasado. Curso llevado a cabo en el Centro Cultural de la Memoria Haroldo Conti. Buenos Aires, Argentina. [Apuntes personales].

. (2007). Historia y Memoria. Notas sobre un debate. En: Franco, M. y Levín, F.

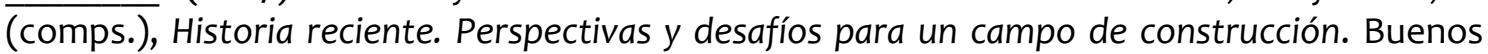
Aires: Paidós.

Uprimny Salazar, C. (Julio 9 de 2012). La memoria en la Ley de Víctimas en Colombia: derecho y deber. Anuario De Derechos Humanos, o(8). Recuperado de:

http://www.anuariocdh.uchile.cl/index.php/ADH/article/viewArticle/20563/21733

Uribe, M.T y López Lopera, L. (2010). Las palabras de la guerra. Un estudio sobre las guerras civiles en Colombia. Medellín: La Carreta.

Vecchioli, V. (2013). Las Víctimas del Terrorismo de Estado y la gestión del pasado reciente en la Argentina. Papeles del CEIC, 1, 1-25. Recuperado de:

http://www.redalyc.org/articulo.oa?id=76525696001

Vélez O., A. (2005). Cartago, Pereira, Manizales: cruce de caminos históricos. Pereira: Papiro.

Verdad Abierta. Desplazamiento y despojo de Tierras: estrategia paramilitar. Recuperado de: http://www.verdadabierta.com/despojo-de-tierras/210-desplazamiento-y-despojo-de-tierras-estrategiaparamilitar

Vezzetti, H. (Octubre 2007). La memoria justa: política e historia. En: Coloquio Internacional Problemas de historia reciente en el Cono Sur. Los Polvorines, Provincia de Buenos Aires.

Villarraga, A. (2009). Posibilidades de una comisión de la verdad. Recuperado en: http://www.setianworks.net/indepazHome/index.php?view=article\&id=145\%3Aposibilidades -de-una-comision-de-la-verdad\&option=com_content\&ltemid=77

Yerushalmi, Y.H.(2002) Zajor. La historia judía y la memoria judía. Barcelona: Anthropos.

Williams, Raymond. (1997) [1977]. Marxismo y literatura. Barcelona: Península.

Zorrilla Martínez, P. (Noviembre, 1995). El Estado de derecho, los valores y los derechos humanos. En: Primer Simposio Internacional de Derechos Humanos, organizado por la Comisión Juvenil Mexicana de Derechos Humanos. Monterrey, Nuevo León.

\section{Artículos sin autor}

Sí hay guerra, señor presidente. (2005, 6 de febrero). En: Revista Semana. Recuperado en: http://www.semana.com/portada/guerra-senor-presidente/84650-3.aspx

Nadie se salva. (1987, 8 de junio). En: Revista Semana. Recuperado en: http://www.semana.com/wf_ImprimirArticulo.aspx?IdArt=23392) 
Freno publicitario a la Violencia. Admirable jornada de los periodistas colombianos. Una declaración para enmarcar en las salas de redacción. (1962, 7 de octubre) En: El Tiempo, p. 12. 